\title{
DEVELOPMENT OF NEW ARTIFICIAL INSEMINATION EXTENDERS SUPPLEMENTED WITH GnRH ANALOGUES TO INDUCE OVULATION AND PROTEOMIC CHARACTERIZATION OF RABBIT SEMEN
}

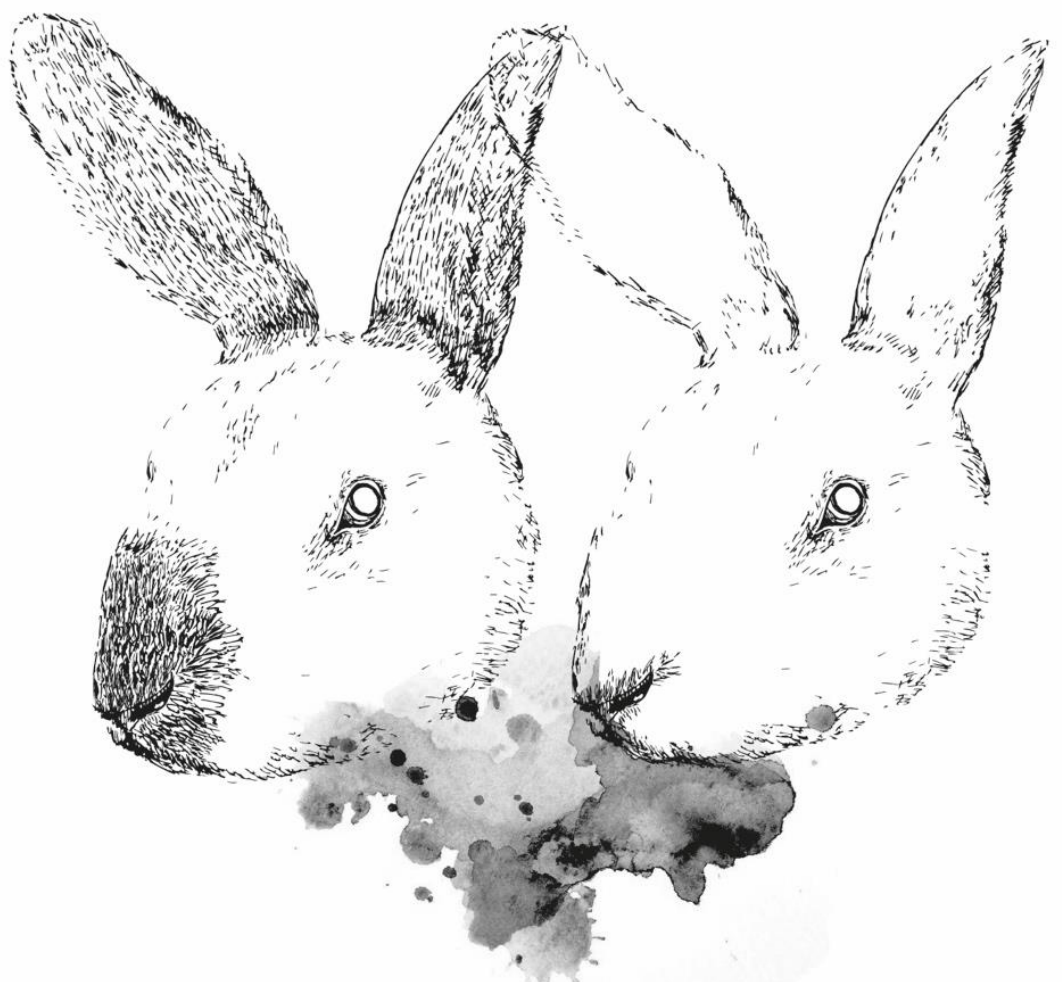

\section{PH.D THESIS BY \\ LUCÍA CASARES CRESPO}

SUPERVISOR

MARÍA PILAR VIUDES DE CASTRO

FEBRUARY 2018

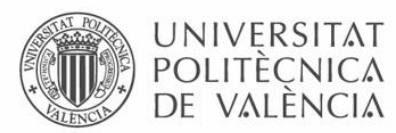





\title{
UNIVERSITAT POLITÈCNICA DE VALÈNCIA
}

\section{DEVELOPMENT OF NEW ARTIFICIAL INSEMINATION \\ EXTENDERS SUPPLEMENTED WITH GnRH ANALOGUES \\ TO INDUCE OVULATION AND PROTEOMIC \\ CHARACTERIZATION OF RABBIT SEMEN}

\begin{abstract}
A thesis submitted to the Polytechnic University of Valencia in partial fulfilment of the requirements for the degree of doctor of philosophy By

Lucía Casares Crespo
\end{abstract}

Sig.

Thesis Supervisor

María Pilar Viudes de Castro

Sig. 



\section{AGRADECIMIENTOS}

En este apartado, me gustaría dedicar unas palabras a todas aquellas personas que me han acompañado durante este tiempo y que forman parte de mí y de esta tesis.

En primer lugar a mi directora de tesis Pilar. Gracias por darme la oportunidad de estar tres años a tu lado aprendiendo. Por llevarme de tu mano y guiarme con paciencia y amabilidad en este proceso largo y tedioso que es una tesis. A pesar de los madrugones para llegar a Segorbe y del frío, allí me he sentido como en casa y he disfrutado. He tenido mucha suerte de haber contado con una directora, guía y amiga excepcional. Agradezco la confianza que has depositado en mí y el tiempo que me has dedicado. Ha sido un placer.

Y como no se puede hablar de Pilar sin hablar de José, aprovecho para agradecerle su ayuda y atención siempre que lo he necesitado. Durante la carrera me pareciste un buen profesor y ahora sé que además eres una gran persona.

Me acuerdo también de mis becarios del CITA, Andrés y Silvia. Agradeceros los ratitos de risas y conversación que hemos pasado en el despacho o en la granja y esos encuentros de estudiantes de doctorado en lo que nos atiborrábamos a comida. Los echo de menos. También a Marisa, Ernesto, Laura y el resto de la familia CITA, que han contribuido a mi felicidad durante estos últimos años. A mi querida Paula, que llegó de forma inesperada pero que nos abrió un mundo de posibilidades con la encapsulación y que ha sido una gran compañera, a la que me llevo como amiga.

Gracias también a los compañeros/amigos de la UPV. Carmen, Amparo, Ximo, Luis y Paco. Siempre nos habéis recibido con los brazos abiertos y os guardo mucho cariño. 
No puedo dejar de nombrar a mis queridas biotecnólogas. Con vosotras empezó mi aventura en el mundo de la ciencia y me alegra decir que seguimos creciendo juntas. A mis amigos de Alboraya: Javi, Alba, Elena y Cristina. Gracias por vuestra amistad y los grandes ratos juntos.

Agradecer a mi familia el apoyo y la paciencia que han tenido conmigo. Sobre todo a mis padres y a Jorge, que han aguantado festivos y fines de semana encerrados en casa y casi sin poder hablar mientras yo escribía la tesis. También a mi hermana, que desde la distancia ha ido participando de mis avances y retrocesos en la tesis. Os quiero. Por último, me gustaría recordar a todos aquellos conejos que murieron en el incendio accidental de la granja del CITA aquel fatídico 31 de mayo de 2015. Sin ellos, muchos de los experimentos de esta tesis no hubieran sido posibles. Aún me acuerdo de vosotros. 


\section{ABSTRACT}

The general objectives of this thesis were to develop new artificial insemination extenders supplemented with a $\mathrm{GnRH}$ analogue in order to induce doe ovulation and to characterise the proteomic profile of rabbit semen.

In chapter I, the inclusion of a protease inhibitors cocktail in the insemination extender to avoid part of the rabbit seminal plasma protease activity was evaluated. Seminal quality and fertility rate were not affected by the cocktail, having similar values between experimental and control groups. However, prolificacy rate was significantly lower in experimental group compared to positive and negative control groups ( $8.2 \pm$ 0.22 vs. $9.3 \pm 0.23$ and $9.2 \pm 0.26$ total born per litter, respectively). From this chapter, it may be concluded that the addition of a wide variety of protease inhibitors in the rabbit semen extender negatively affects prolificacy rate and it in the future it would be advisable to test specific aminopeptidase inhibitors.

Therefore, in chapter II, we supplemented the insemination extender with specific aminopeptidase inhibitors (bestatin and EDTA), and we studied their effect on rabbit seminal quality and reproductive performance. Again, the values of motility, acrosome integrity and sperm viability were not significantly different between the experimental and the control group. Regarding reproductive performance, the inclusion of bestatin and EDTA, did not affect fertility (85.3 vs. $88.6 \%)$, nor the prolificacy rate (10.12 vs. 10.51 kits per delivery) in comparison with control group. Thus, we concluded that bestatin and EDTA can be used in rabbit insemination extenders to inhibit part of the seminal plasma aminopeptidase activity. 
In the light of previous results, in chapter III, we prove new rabbit insemination extenders containing aminopeptidase inhibitors (AMIs) with or without chitosan (CS)dextran sulfate (DS) nanoparticles entrapping the GnRH analogue. Besides, different hormone concentrations were tested in these extenders, evaluating their in vivo effect on rabbit reproductive performance after artificial insemination. The following experimental extenders were studied: C4 group (4 $\mathrm{\mu g}$ buserelin/doe in control medium: Tris-citric acid-glucose supplemented with bestatin $10 \mu \mathrm{M}$ and EDTA $20 \mathrm{mM}$ ), C5 group (5 $\mu \mathrm{g}$ of buserelin/doe in control medium), Q4 group (4 $\mu \mathrm{g}$ of buserelin/doe into CS-DS nanoparticles in control medium) and Q5 group (5 $\mathrm{gg}$ of busereline/doe into CS-DS nanoparticles in control medium). Results showed that fertility was significantly lower in C4 group compared to C5, Q5 and Q4 groups ( 0.7 versus $0.85,0.85$ and 0.82 , respectively). On the contrary, prolificacy was similar in the four experimental groups studied $(P>0.05)$. Thus, we concluded that the CS-DS nanoparticles prepared by a coacervation process as carrier for buserelin acetate allow to reduce the concentration of hormone used in extenders supplemented with bestatin and EDTA without affecting the fertility and prolificacy of rabbit females. Therefore, nanoencapsulation seems to be a promising system to protect the $\mathrm{GnRH}$ analogue in order to decrease the hormone concentration in rabbit artificial insemination extenders.

On the other hand, the aim of the last three chapters of the present thesis was to characterize rabbit seminal plasma and sperm proteome. In chapters IV and V, we characterised rabbit seminal plasma proteins (SP proteins) focusing on the influence of the genetic origin and seasonality. Semen samples were recovered from January to December 2014 using 6 males belonging to genotype A and 6 from genotype R. For each genotype, one pooled sample at the beginning, middle and end of each season 
was selected to develop the experiment. A total of 24 pools ( 3 for each season and genetic line) were analysed. In chapter IV, we used a 1D polyacrylamide gel electrophoresis approach and we observed that seven protein bands were significantly different between genetic lines and among these, three protein bands were significantly different between seasons. On the contrary, in chapter V, SP was subjected to in-solution digestion nano LC-MS/MS and bioinformatics analysis. The resulting library included 402 identified and quantified proteins. Only 6 proteins were specifically implicated in reproductive processes according to Gene Ontology annotation. Twenty-three proteins were differentially expressed between genotypes, 11 over-expressed in genotype A and 12 in genotype R. Regarding the effect of season on rabbit SP proteome, results showed that there was no clear pattern of protein variation throughout the year. The results obtained in both chapters provide evidence that genotype is related to a specific abundance of SP proteins.

The final chapter of this thesis was conducted to characterise rabbit sperm proteins through LC-MS/MS technique. Six samples were recovered during two months from five males from genotype A and five from genotype R. Sperm proteins were extracted and subjected to in-gel digestion nano LC-MS/MS and bioinformatics analysis. The resulting library included 487 identified and quantified proteins. Regarding the comparison of the sperm proteins' abundance between genotypes, forty proteins were differentially expressed. Among them, 25 proteins were over-expressed in genotype $A$, while 15 proteins were over-expressed in genotype R. In conclusion, this last chapter characterizes for the first time rabbit sperm proteins and shows that genotype has also a huge impact on protein abundance in rabbit sperm. Furthermore, the differential presence of these proteins could be one of the causes explaining the differences 
observed in fertility and seminal parameters between these two genetic lines in earlier studies. Finally, with the results obtained in chapters $\mathrm{V}$ and $\mathrm{VI}$, the first publicly accessible database of the rabbit seminal plasma and sperm proteome was created. 


\section{RESUMEN}

Los objetivos generales de esta tesis fueron desarrollar nuevos diluyentes de inseminación artificial suplementados con un análogo de la GnRH para inducir la ovulación de la coneja y caracterizar el perfil proteómico del semen de conejo. En el capítulo I, se evaluó la inclusión de un cóctel de inhibidores de proteasas en el diluyente de inseminación para evitar parte de la actividad proteasa del plasma seminal de conejo. La calidad seminal y la tasa de fertilidad no se vieron afectadas por el cóctel, teniendo valores similares entre los grupos experimentales y el control. Sin embargo, la tasa de prolificidad fue significativamente menor en el grupo experimental en comparación con los grupos de control positivo y negativo $(8,2 \pm 0,22$ frente a $9,3 \pm$ 0,23 y 9,2 $\pm 0,26$ nacidos totales por camada, respectivamente). A partir de este capítulo, se puede concluir que la adición de una amplia variedad de inhibidores de proteasas en el diluyente de semen de conejo afecta negativamente la tasa de prolificidad y que en el futuro sería aconsejable probar inhibidores específicos de aminopeptidasas.

Por lo tanto, en el capítulo II, suplementamos el diluyente de inseminación con inhibidores específicos de aminopeptidasas (bestatina y EDTA), y estudiamos su efecto sobre la calidad seminal del conejo y el rendimiento reproductivo. Nuevamente, los valores de motilidad, integridad del acrosoma y la viabilidad del esperma no fueron significativamente diferentes entre el grupo experimental y el control. Con respecto al desempeño reproductivo, la inclusión de bestatina y EDTA, no afectó la fertilidad (85,3 vs. $88,6 \%)$, ni la tasa de prolificidad $(10,12$ vs. 10,51 gazapos por parto) en comparación con el grupo control. Por lo tanto, llegamos a la conclusión de que la 
bestatina y el EDTA se pueden usar en los diluyentes de inseminación de conejos para inhibir parte de la actividad aminopeptidasa del plasma seminal. A la luz de los resultados previos, en el capítulo III, probamos nuevos diluyentes de inseminación de conejo, los cuales contenían inhibidores de aminopeptidasas con o sin nanopartículas de quitosano (CS)-sulfato de dextrano (DS) que atrapan el análogo de la GnRH. Además, se probaron diferentes concentraciones de hormona en estos diluyentes, evaluando su efecto in vivo sobre el rendimiento reproductivo del conejo después de la inseminación artificial. Se estudiaron los siguientes diluyentes experimentales: grupo C4 (4 $\mu \mathrm{g}$ de buserelina/coneja en medio de control: tris-ácido cítrico-glucosa suplementado con $10 \mu \mathrm{M}$ de bestatina y EDTA $20 \mathrm{mM}$ ), grupo C5 (5 $\mathrm{gg}$ de buserelina/coneja en medio de control), Grupo Q4 (4 $\mu \mathrm{g}$ de buserelina/coneja en nanopartículas CS-DS en medio de control) y grupo Q5 (5 $\mu \mathrm{g}$ de buserelina/coneja en nanopartículas CS-DS en medio de control). Los resultados mostraron que la fertilidad fue significativamente menor en el grupo C4 en comparación con los grupos C5, Q5 y Q4 (0,7 frente a $0,85,0,85$ y 0,82 , respectivamente). Por el contrario, la prolificidad fue similar en los cuatro grupos experimentales estudiados $(P>0,05)$. Por lo tanto, llegamos a la conclusión de que las nanopartículas de CS-DS preparadas mediante un proceso de coacervación como transportador de acetato de buserelina permiten reducir la concentración de hormona utilizada en diluyentes suplementados con bestatina y EDTA sin afectar la fertilidad y prolificidad de las hembras de conejo. Por ello, la nanoencapsulación parece ser un sistema prometedor para proteger el análogo de la GnRH a fin de disminuir la concentración de la hormona en los diluyentes de inseminación artificial de conejos. 
Por otro lado, el objetivo de los últimos tres capítulos de esta tesis fue caracterizar el proteoma del plasma seminal y del espermatozoide de conejo. En los capítulos IV y $\mathrm{V}$, caracterizamos las proteínas del plasma seminal del conejo centrándonos en la influencia del origen genético y la estacionalidad. Las muestras de semen se recuperaron de enero a diciembre de 2014 utilizando 6 machos pertenecientes al genotipo A y 6 del genotipo R. Para cada genotipo, se seleccionó una muestra heteroespérmica del comienzo, del medio y del final de cada estación para desarrollar el experimento. Se analizaron un total de 24 muestras (3 para cada estación y línea genética). En el capítulo IV, utilizamos un enfoque de electroforesis en gel de poliacrilamida 1D y observamos que siete bandas de proteínas eran significativamente diferentes entre las líneas genéticas y de éstas, tres bandas de proteínas eran significativamente diferentes entre las estaciones. Por el contrario, en el capítulo V, el plasma seminal se sometió a una digestión en solución, nano LC-MS/MS y análisis bioinformático. La biblioteca resultante incluía 402 proteínas identificadas y cuantificadas. Sólo 6 proteínas estuvieron específicamente implicadas en procesos reproductivos de acuerdo con la anotación funcional. Veintitrés proteínas se expresaron diferencialmente entre genotipos, 11 sobreexpresadas en el genotipo A y 12 en el genotipo R. Con respecto al efecto de la estación en el proteoma del plasma seminal del conejo, los resultados mostraron que no hubo un patrón claro de variación proteica a lo largo del año. Los resultados obtenidos en ambos capítulos evidencian que el genotipo está relacionado con una abundancia específica de proteínas del plasma seminal.

El último capítulo de la tesis se realizó para caracterizar las proteínas del espermatozoide de conejo a través de la técnica LC-MS/MS. Seis muestras se 
recuperaron durante dos meses de cinco machos del genotipo A y cinco del genotipo R. Las proteínas del espermatozoide se extrajeron y se sometieron a digestión en gel, nano LC-MS / MS y análisis bioinformático. La biblioteca resultante incluyó 487 proteínas identificadas y cuantificadas. En cuanto a la comparación de la abundancia de proteínas del esperma entre genotipos, cuarenta proteínas se expresaron diferencialmente. Entre ellas, 25 proteínas se sobreexpresaron en el genotipo A, mientras que 15 proteínas se sobreexpresaron en el genotipo R. En conclusión, este último capítulo caracteriza por primera vez las proteínas del espermatozoide del conejo y muestra que el genotipo también tiene un gran impacto en la abundancia de proteínas del espermatozoide de conejo. Además, la presencia diferencial de estas proteínas podría ser una de las causas que explican las diferencias observadas en la fertilidad y los parámetros seminales entre estas dos líneas genéticas en estudios anteriores. Finalmente, con los resultados obtenidos en los capítulos V y VI, se creó la primera base de datos de acceso público del proteoma del plasma seminal y del espermatozoide de conejo. 


\section{RESUM}

Els objectius generals d'aquesta tesi van ser desenvolupar nous diluents d'inseminació artificial suplementats amb un anàleg de la GnRH per induir l'ovulació de la conilla i caracteritzar el perfil proteòmic del semen de conill. En el capítol I, es va avaluar la inclusió d'un còctel d'inhibidors de proteases en el diluent d'inseminació per evitar part de l'activitat proteasa del plasma seminal de conill. La qualitat seminal i la taxa de fertilitat no es van veure afectades pel còctel, tenint valors similars entre els grups experimentals i el control. No obstant això, la taxa de prolificitat va ser significativament menor en el grup experimental en comparació amb els grups de control positiu i negatiu $(8,2 \pm 0,22$ enfront de $9,3 \pm 0,23$ i 9,2 $\pm 0,26$ nascuts totals per ventrada, respectivament). A partir d'aquest capítol, es pot concloure que l'addició d'una àmplia varietat d'inhibidors de proteases en el diluent de semen de conill afecta negativament la taxa de prolificitat $\mathrm{i}$ que en el futur seria aconsellable provar inhibidors específics de aminopeptidasas.

Per tant, en el capítol II, suplementàrem el diluent d'inseminació amb inhibidors específics de aminopeptidasas (bestatina i EDTA), i vam estudiar el seu efecte sobre la qualitat seminal del conill i el rendiment reproductiu. Novament, els valors de motilitat, integritat de l'acrosoma i la viabilitat de l'esperma no van ser significativament diferents entre el grup experimental i el control. Pel que fa al rendiment reproductiu, la inclusió de bestatina i EDTA, no va afectar la fertilitat (85,3 vs. $88,6 \%)$, ni la taxa de prolificitat $(10,12$ vs. 10,51 catxaps per part) en comparació amb el grup control. Per tant, arribem a la conclusió que la bestatina i l'EDTA es poden 
usar en els diluents d'inseminació de conills per inhibir part de l'activitat aminopeptidasa del plasma seminal.

A la llum dels resultats previs, en el capítol III, vam provar nous diluents d'inseminació de conill, els quals contenien inhibidors de aminopeptidasas amb o sense nanopartícules de quitosà (CS)-sulfat de dextrà (DS) que atrapen l'anàleg de la GnRH. A més, es van provar diferents concentracions d'hormona en aquests diluents, avaluant el seu efecte in vivo sobre el rendiment reproductiu del conill després de la inseminació artificial. Es van estudiar els següents diluents experimentals: grup C4 (4 $\mu g$ de buserelina/conilla en medi control: tris-àcid cítric-glucosa suplementat amb 10 $\mu \mathrm{L}$ de bestatina i $20 \mathrm{mM}$ d'EDTA), grup C5 (5 $\mu \mathrm{g}$ de buserelina/conilla en medi control), grup Q4 (4 $\mu$ g de buserelina/conilla en nanopartícules CS-DS en medi control) i grup Q5 (5 $\mu \mathrm{g}$ de buserelina/conilla en nanopartícules CS-DS en medi control). Els resultats van mostrar que la fertilitat va ser significativament menor en el grup C4 en comparació amb els grups C5, Q5 i Q4 (0,7 enfront de 0,85, 0,85 i 0,82, respectivament). Per contra, la prolificitat va ser similar en els quatre grups experimentals estudiats $(P>0,05)$. Per tant, arribem a la conclusió que les nanopartícules de CS-DS preparades mitjançant un procés de coacervació com a transportador d'acetat de buserelina permeten reduir la concentració d'hormona utilitzada en diluents suplementats amb bestatina i EDTA sense afectar la fertilitat ni la prolificitat de les femelles de conill. Per tant, la nanoencapsulació sembla ser un sistema prometedor per protegir l'anàleg de la GnRH per tal de disminuir la concentració de l'hormona en els diluents d'inseminació artificial de conills.

D'altra banda, l'objectiu dels últims tres capítols d'aquesta tesi va ser caracteritzar el proteoma del plasma seminal i de l'espermatozoide de conill. En els capítols IV i V, 
caracteritzàrem les proteïnes del plasma seminal del conill centrant-nos en la influència de l'origen genètic i l'estacionalitat. Les mostres de semen es van recuperar de gener a desembre de 2014 utilitzant 6 mascles pertanyents al genotip A i 6 del genotip R. Per a cada genotip, es va seleccionar una mostra heteroespérmica del començament, del mitjan i del final de cada estació per desenvolupar l'experiment. Es van analitzar un total de 24 mostres ( 3 per a cada estació i línia genètica). En el capítol IV, ferem servir un enfocament d'electroforesi en gel de poliacrilamida 1D i observàrem que set bandes de proteïnes eren significativament diferents entre les línies genètiques i entre aquestes, tres bandes de proteïnes eren significativament diferents entre les estacions. Per contra, en el capítol V, el plasma seminal es va sotmetre a una digestió en solució, nano LC-MS / MS i anàlisi bioinformàtica. La biblioteca resultant incloïa 402 proteïnes identificades i quantificades. Només 6 proteïnes van estar específicament implicades en processos reproductius d'acord amb l'anotació funcional. Vint-i-tres proteïnes es van expressar diferencialment entre genotips, 11 sobreexpressades en el genotip A i 12 en el genotip R. Pel que fa a l'efecte de l'estació en el proteoma del plasma seminal del conill, els resultats van mostrar que no hi havia un patró clar de variació proteica a llarg de l'any. Els resultats obtinguts en els dos capítols evidencien que el genotip està relacionat amb una abundància específica de proteïnes del plasma seminal. L'últim capítol de la tesi es va realitzar per caracteritzar proteïnes de l'espermatozoide de conill a través de la tècnica LC-MS/MS. Sis mostres es van recuperar durant dos mesos de cinc mascles del genotip A i cinc del genotip R. Les proteïnes de l'espermatozoide es van extreure i es van sotmetre a digestió en gel, nano LC-MS/MS i anàlisi bioinformàtica. La biblioteca resultant va incloure 487 proteïnes identificades i 
quantificades. Pel que fa a la comparació de l'abundància de proteïnes de l'espermatozoide entre genotips, quaranta proteïnes es van expressar diferencialment. Entre elles, 25 proteïnes es sobreexpresaren en el genotip A, mentre que 15 proteïnes es sobreexpresaren en el genotip R. En conclusió, aquest últim capítol caracteritza per primera vegada les proteïnes de l'espermatozoide del conill i mostra que el genotip també té un gran impacte en l'abundància de proteïnes de l'esperma de conill. A més, la presència diferencial d'aquestes proteïnes podria ser una de les causes que expliquen les diferències observades en la fertilitat i els paràmetres seminals entre aquestes dues línies genètiques en estudis anteriors. Finalment, amb els resultats obtinguts en els capítols $\mathrm{V}$ i VI, es va crear la primera base de dades d'accés públic del proteoma del plasma seminal i de l'espermatozoide de conill. 


\section{INDEX OF CONTENTS}

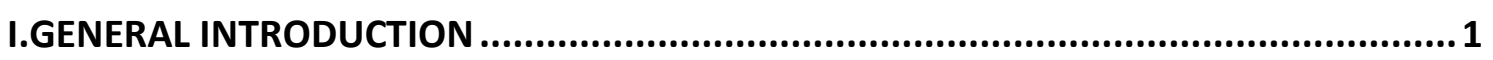

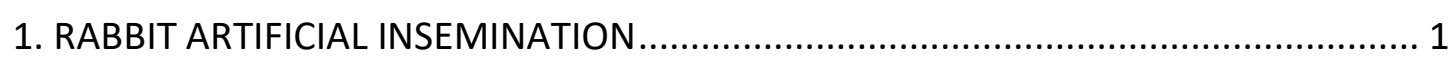

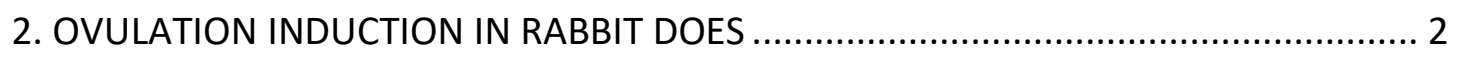

3. NEW EXTENDERS FOR RABBIT ARTIFICIAL INSEMINATION ................................ 6

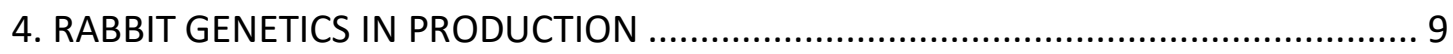

5. IMPORTANCE OF RABBIT BUCK IN REPRODUCTION ......................................... 11

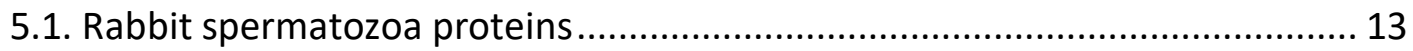

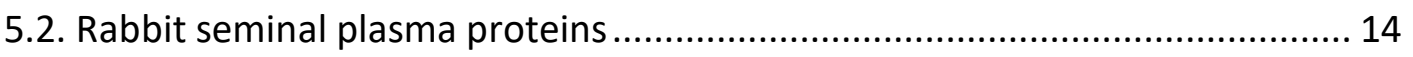

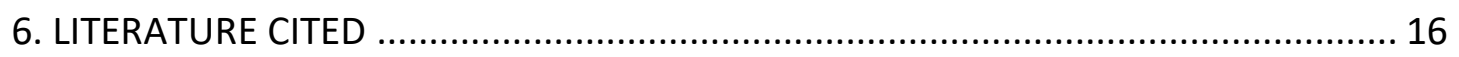

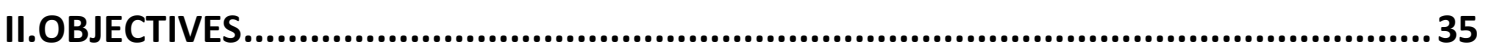

III.CHAPTER I. Does the inclusion of protease inhibitors in the insemination extender affect rabbit reproductive performance?

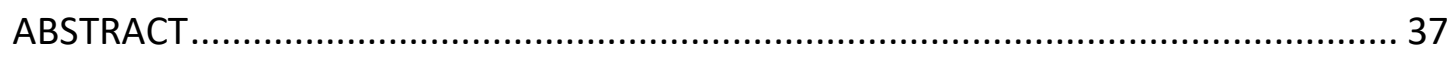

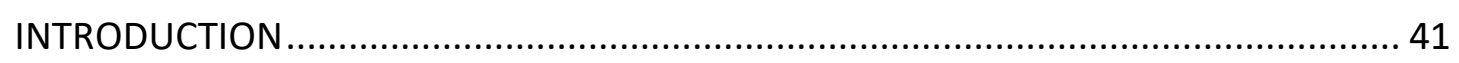

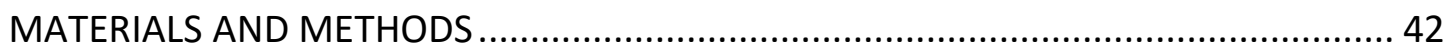

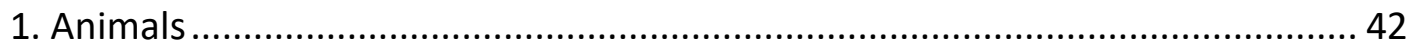

2. In vitro effect of protease inhibitors on seminal quality................................ 43

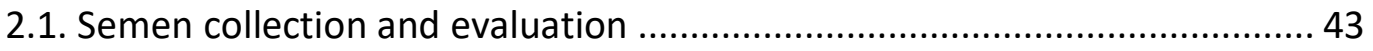

2.2. Protease inhibitor activity evaluation .................................................... 44

2.3. Seminal plasma preparation and measurement of APN activity ................ 45

3. In vivo effect of protease inhibitors on reproductive performance .................. 46

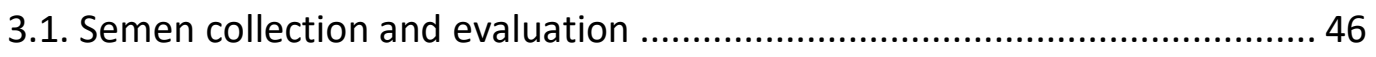

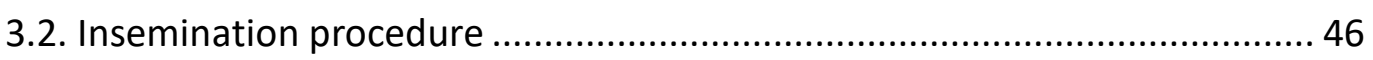

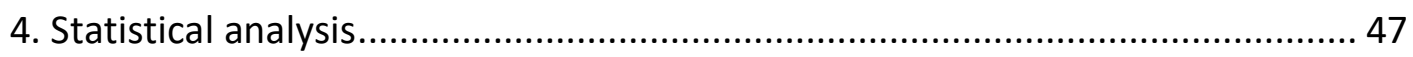


RESULTS

1. Effect of protease inhibitors on seminal quality ........................................... 47

2. Effect of protease inhibitors in fertility and prolificacy .................................... 48

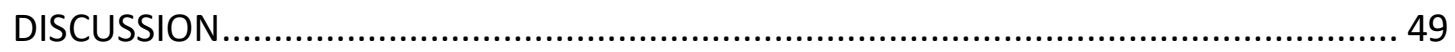

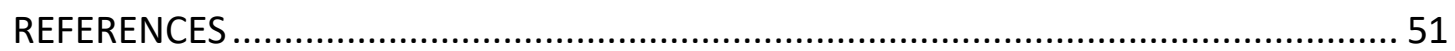

IV.CHAPTER II. Insemination extender supplementation with bestatin and EDTA has no effect on rabbit reproductive performance

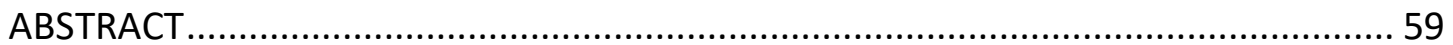

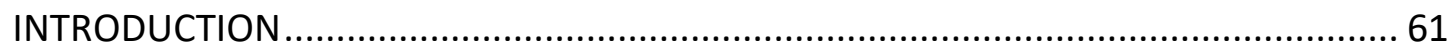

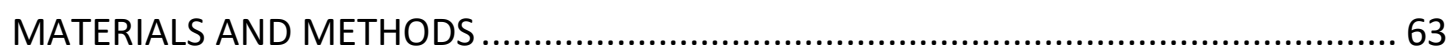

1. In vitro effect of aminopeptidase inhibitors on seminal quality...................... 63

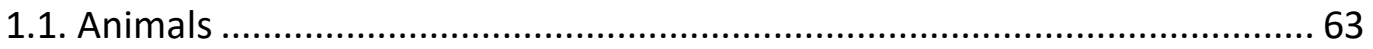

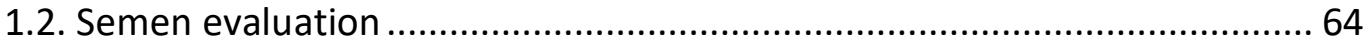

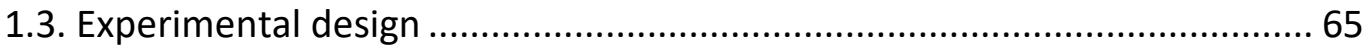

1.4. Measurement of aminopeptidase activity on seminal plasma (APN) ..........66 66

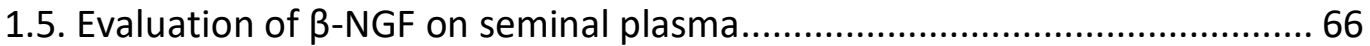

2. In vivo effect of aminopeptidase inhibitors on reproductive performance .......67

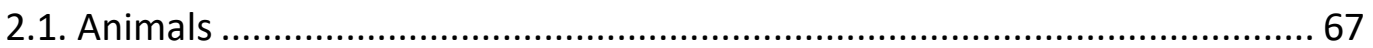

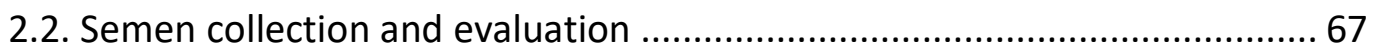

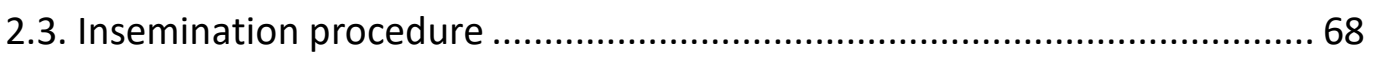

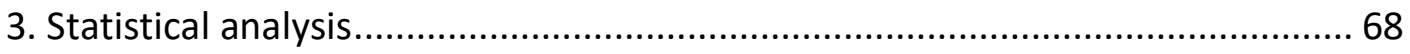

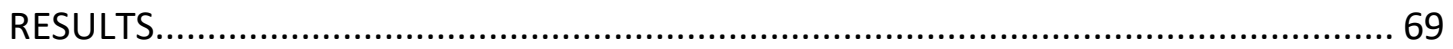

1. Effect of aminopeptidase inhibitors on seminal quality .................................69

2. Effect of aminopeptidase inhibitors on $\beta$-NGF quantity ................................. 70

3. Effect of aminopeptidase inhibitors on fertility and prolificacy ....................... 70

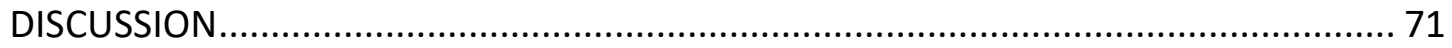


V.CHAPTER III. Protection of GnRH analogue by chitosan-dextran sulfate nanoparticles for intravaginal application in rabbit artificial insemination

ABSTRACT

1. Seminal quality after insemination with experimental extenders ................... 91

2. Reproductive performance of experimental extenders ................................ 92

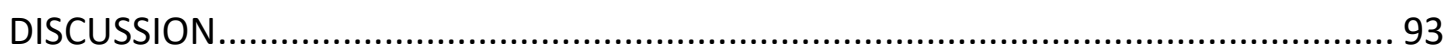

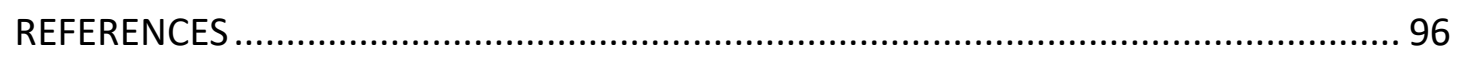

VI.CHAPTER IV. Can the genetic origin affect rabbit seminal plasma protein profile along the year?

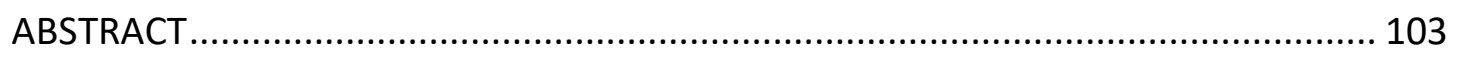

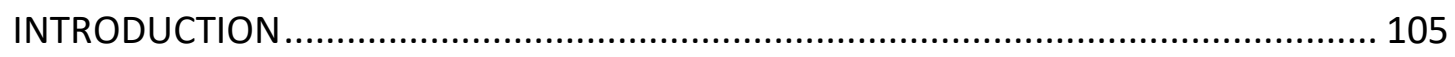

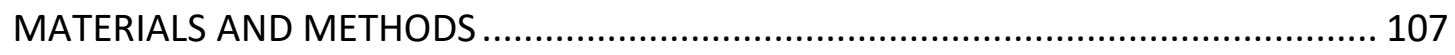

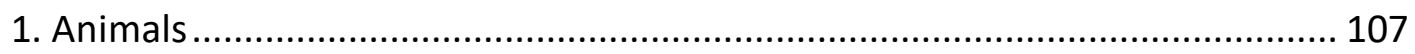

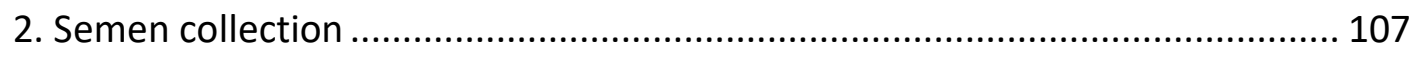

3. Preparation of seminal plasma samples .................................................. 108

4. Polyacrylamide gel electrophoresis (SDS-PAGE) ........................................ 109

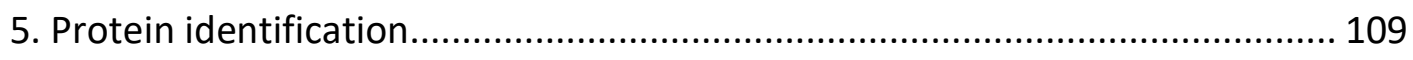


6. MALDI TOF/TOF analysis

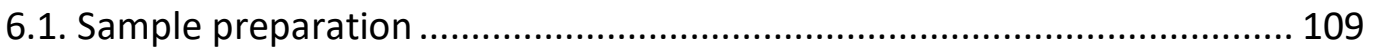

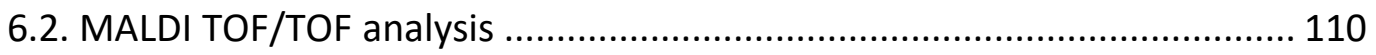

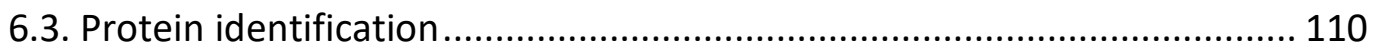

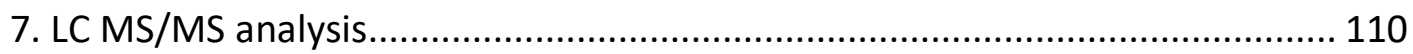

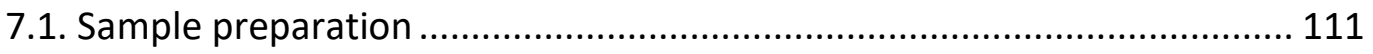

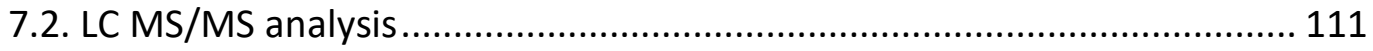

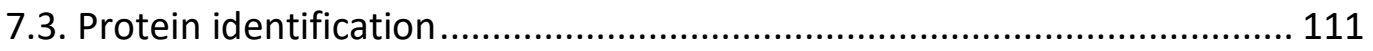

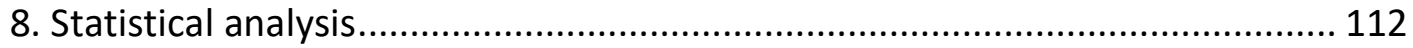

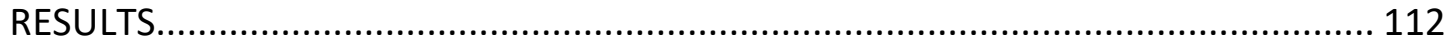

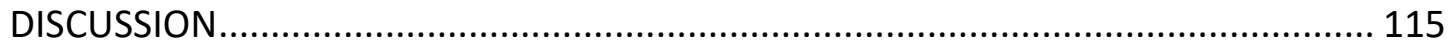

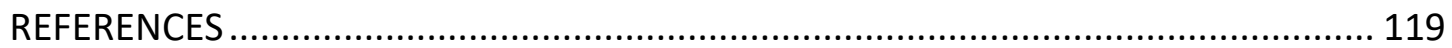

VII.CHAPTER V. Rabbit seminal plasma proteome: the importance of the genetic origin

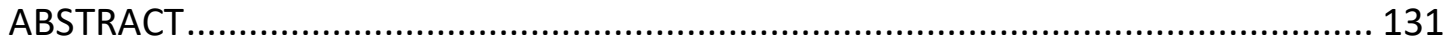

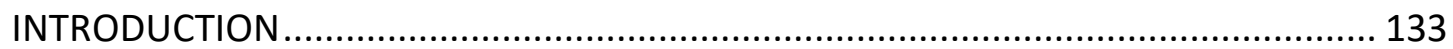

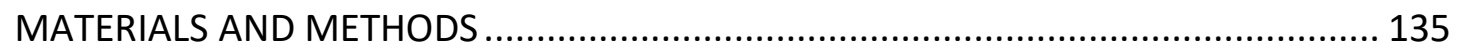

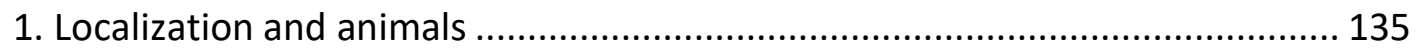

2. Semen collection and preparation of seminal plasma samples ...................... 136

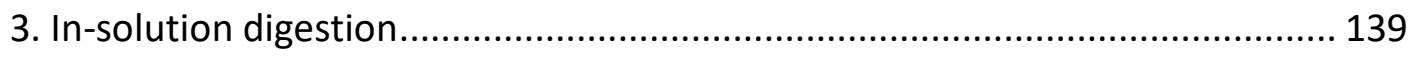

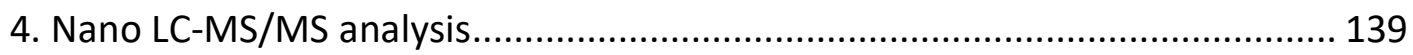

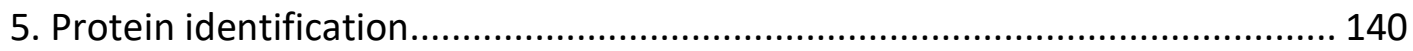

6. Label-free protein quantification using Chromatographic Areas ..................... 141

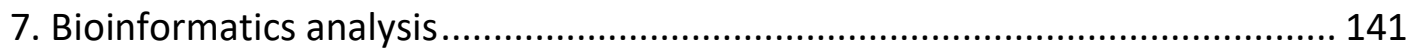

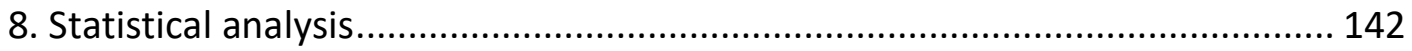

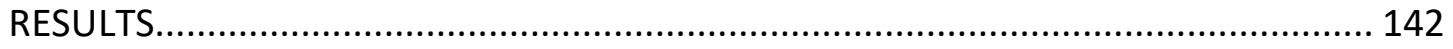


1. Rabbit seminal plasma proteome

2. Effect of genetic origin on seminal plasma proteome ................................. 144

3. Effect of season on seminal plasma proteome .................................................. 148

4. $\beta$-NGF relative quantification in rabbit seminal plasma ................................ 150

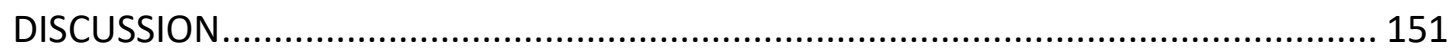

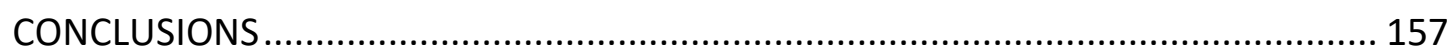

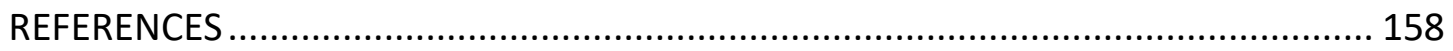

VIII.CHAPTER VI. Characterization of rabbit (Oryctolagus cuniculus) sperm proteins

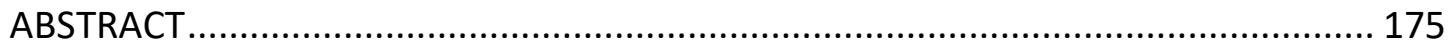

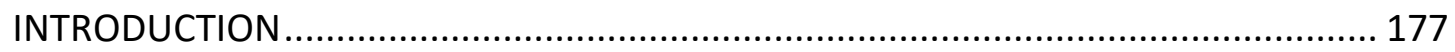

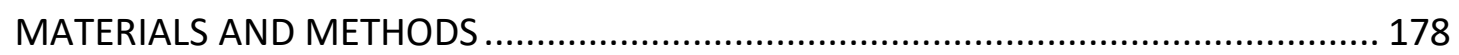

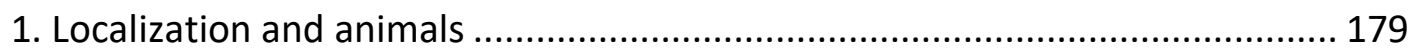

2. Semen collection, evaluation and sperm samples preparation....................... 179

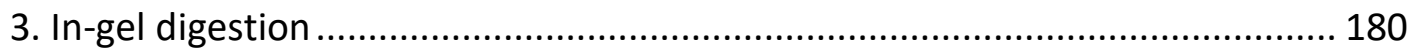

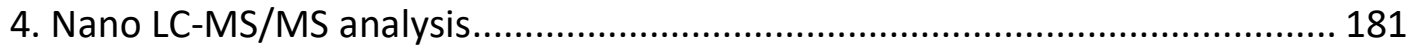

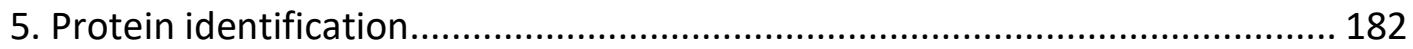

6. Label-free protein quantification using Chromatographic Areas .................... 183

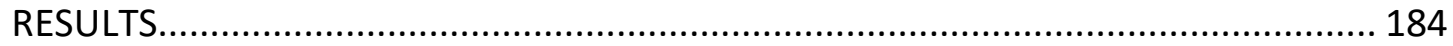

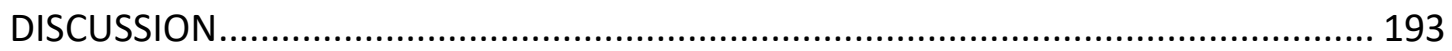

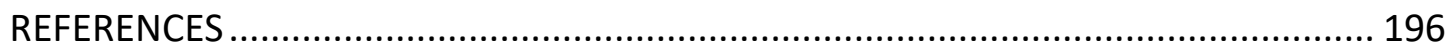

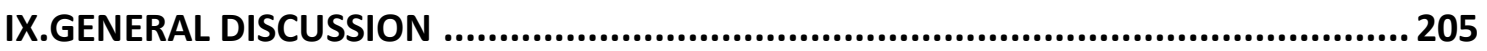

1. DEVELOPMENT OF NEW ARTIFICIAL INSEMINATION EXTENDERS SUPPLEMENTED

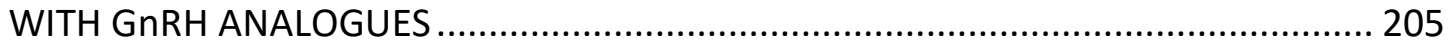

2. PROTEOMIC CHARACTERIZATION OF RABBIT SEMEN ...................................... 212

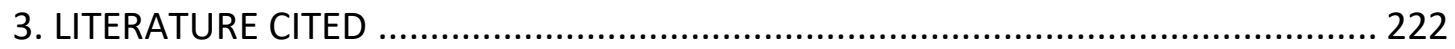

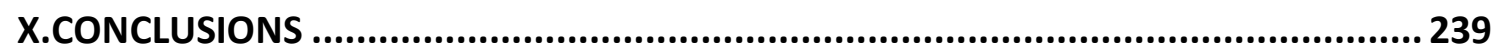

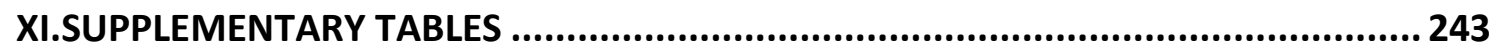


CHAPTER V. RABBIT SEMINAL PLASMA: THE IMPORTANCE OF THE GENETIC ORIGIN.

CHAPTER VI. CHARACTERIZATION OF RABBIT (ORYCTOLAGUS CUNICULUS) SPERM PROTEOME. 


\section{INDEX OF FIGURES}

\section{I.GENERAL INTRODUCTION}

Figure I.1. Ovulation cycle of spontaneous ovulators....................................... 3

Figure I.2. Ovulation cycle of reflex ovulators................................................. 4

Figure 1.3. Protein structure of ovulation-inducing factor (OIF) from llama seminal plasma. (A) Monomer of OIF. (B) Biological dimer of OIF.

Figure I.4. Picture of rabbit genetic lines $\mathrm{R}$ (left) and $A$ (right).......................... 10

Figure I.5. Gel plug of rabbit's ejaculate. 12

\section{IV.CHAPTER II}

Figure 2.1. Time-dependent effect of aminopeptidase inhibitors $(10 \mu \mathrm{M}$ bestatin and $20 \mathrm{mM}$ EDTA) on seminal $\beta-\mathrm{NGF}$ (means \pm standard error). 70

\section{VI.CHAPTER IV}

Figure 4.1. 5-13\% SDS-PAGE of rabbit seminal plasma proteins. Lane 1 and 6 are molecular weight markers ( 250 to $25 \mathrm{kDa}$ ). Lane 2 and 3 are $A$ and $R$ line in winter, respectively. Lane 4 and 5 are $A$ and $R$ line in spring. Lane 7 and 8 are $A$ and $R$ line in summer. And lane 9 and 10 are $A$ and $R$ line in autumn.

Figure 4.2. 5-22\% SDS-PAGE of rabbit seminal plasma proteins. Lane 1 and 6 are molecular weight markers ( 37 to $10 \mathrm{kDa}$ ). Lane 2 and 3 are $A$ and $R$ line in winter, respectively. Lane 4 and 5 are $A$ and $R$ line in spring. Lane 7 and 8 are $A$ and $R$ line in summer. And lane 9 and 10 are $A$ and $R$ line in autumn. 114

\section{VII.CHAPTER V}

Figure 5.1. Experimental design scheme. 138

Figure 5.2. Pie charts showing the distribution of rabbit seminal plasma proteins based on their a) molecular function, b) biological process and c) cellular component, using UniProt database in combination with PANTHER. 143 
Figure 5.3. Partial Least Squares Discriminant Analysis (PLS-DA) showing the classification of seminal samples from genotypes $A$ and $R$, based on relative protein amount. 145

Figure 5.4. Heat map representing levels of differentially expressed seminal plasma proteins between genetic origins $A$ and $R$ and hierarchical clustering, showing two main clusters comprising genotype $A$ and $R$. 146

Figure 5.6. Partial Least Squares Discriminant Analysis (PLS-DA) showing the classification of seminal samples belonging to the four seasons, based on relative protein amount.

Figure 5.7. Heat map representing levels of differentially expressed seminal plasma proteins between seasons and hierarchical clustering, showing four main clusters comprising a mixture of samples from different seasons. 150

\section{VIII.CHAPTER VI}

Figure 6.1. Pie charts showing the distribution of rabbit sperm proteins based on their a) molecular function, b) biological process and c) cellular component, using UniProt KB database in combination with PANTHER. 185

Figure 6.2. Discriminant Analysis (DA) showing the classification of spermatozoa protein samples from genotypes $A$ and $R$, based on relative protein amount. 187 
INDEX OF TABLES

\section{I.GENERAL INTRODUCTION}

Table I.1. Fertility and prolificacy rates of rabbits does induced to ovulate with different $\mathrm{GnRH}$ analogues added to the seminal dose.

\section{III.CHAPTER I}

Table 1.1. Reproductive performance of inseminated does. (Least square means \pm standard error). 49

\section{IV.CHAPTER II}

Table 2.1. Seminal quality after two hours' incubation at room temperature with the experimental extenders (\%; least square means \pm standard error). ( $n=35)$

Table 2.2. Reproductive performance of inseminated does induced to ovulate with buserelin acetate applied intramuscularly (Positive Control) or intravaginally with buserelin acetate supplemented extender without (Negative control) or with AMIs.

\section{V.CHAPTER III}

Table 3.1. Seminal quality after insemination procedure with the experimental extenders (\%; Least square means \pm standard error) $(n=3)$.

Table 3.2. Reproductive performance of inseminated does.

\section{VI.CHAPTER IV}

Table 4.1. Temperatures registered during the trial (year 2014) in Segorbe (mean \pm $\mathrm{SD})$. 108

Table 4.2. Relative quantity of significantly different protein bands from rabbit seminal plasma according to genetic line and season ( $L S M \pm S E$ ). 115

\section{VII.CHAPTER V}

Table 5.1. List of differentially expressed proteins in rabbit seminal plasma between genotypes $A$ and $R$.

\section{VIII.CHAPTER VI}

Table 6.1. Rabbit sperm characteristics $(n=4)$. 
Table 6.2. List of differentially expressed rabbit spermatozoa proteins, included in Oryctolagus cuniculus taxonomy, between genotypes A and R 188

\section{XI.SUPPLEMENTARY TABLES}

Table S5.1. contains the complete list of the 402 proteins identified in rabbit seminal plasma with a cut off of two unique peptides and validated with $\geq 95 \%$ Confidence (unused Score $\geq 1.3$ ).

Table S5.2. contains the complete list of the chromatographic areas of the 402 proteins identified in the two rabbit genotypes and the four seasons ( 3 replicates per sample).

Table S5.3. shows the results of the protein quantity T-test comparison between genotypes, including mean protein quantity, t-value, $\mathrm{p}$-value, fold change and log (fold change) of the 402 quantified proteins. 243

Table S6.1. contains the complete list of the 487 proteins identified in rabbit spermatozoa with a cut off of two unique peptides and validated with $\geq 95 \%$ Confidence (unused Score $\geq 1.3$ ).

Table S6.2. contains the complete list of the chromatographic areas of the 487 proteins identified in the two rabbit genotypes (3 replicates per sample).

Table S6.3. shows the results of the protein quantity T-test comparison between genotypes, including mean protein quantity, t-value, $p$-value, fold change and log (fold change) of the 487 quantified proteins. 243 


\section{ABREVIATIONS}

AB

ABC

ACN

Al

ALH

AMIs

ANOVA

APN

AEBSF

BCA

BCF

BSA

oC

$\mathrm{CL}$

cm

cps

CS

eCG

EDTA

ELISA

EU

DA

DE

DM

DS

DTT

FA

FDR

FITC-PNA

fmol
Alive kits born per litter

Ammonium bicarbonate

Acetonitrile

Artificial insemination

Mean amplitude of lateral head displacement

Aminopeptidase inhibitors

Analysis of variance

Aminopeptidase activity

4-(2-Aminoethyl) benzenesulfonyl fluoride hydrochloride

Bicinchoninic acid method

Frequency of head displacement

Bovine serum albumin

Celsius degrees

Corpus lutea

Centimetre

Counts per second

Chitosan

Equine chorionic gonadotropin

Ethylenediaminetetraacetic acid

Enzyme-linked immunosorbent assay

European Union

Discriminant Analysis

Digestible energy

Dry matter

Dextrane sulfate

Dithiothreitol

Formic acid

False discovery rate

Fluorescein labeled lectin from the peanut plant Arachis hypogaea

Femtomole 


\begin{tabular}{|c|c|}
\hline FSH & Follicle stimulating hormone \\
\hline g & Grams \\
\hline GLM & General linear model procedure \\
\hline GnRH & Gonadotropin-releasing hormone \\
\hline GO & Gene ontology \\
\hline h & Hours \\
\hline IAM & lodoacetamide \\
\hline i.m. & Intramuscular \\
\hline IU & International unit \\
\hline i.v. & Intravaginally \\
\hline kcal & Kilocalories \\
\hline kDa & Kilodalton \\
\hline kg & Kilograms \\
\hline kV & Kilovolts \\
\hline LC-MS/MS & Liquid chromatography- mass spectrometry \\
\hline LH & Luteinizing hormone \\
\hline LIN & Linearity coefficient \\
\hline LSD & Least significant difference \\
\hline LSM & Least square means values \\
\hline M & Molar \\
\hline m & Mass \\
\hline MALDI TOF/TOF & Matrix-Assisted Laser Desorption/Ionization Time-of-Flight \\
\hline mg & Milligrams \\
\hline $\min$ & Minutes \\
\hline $\mathrm{mm}$ & Millimetres \\
\hline $\mathrm{mL}$ & Millilitres \\
\hline $\mathrm{mM}$ & Millimolar \\
\hline MSMS & Tandem mass spectrometry \\
\hline $\mathrm{mW}$ & Milliwatt \\
\hline NAR & Normal apical ridge \\
\hline NCBI & National center for biotechnology \\
\hline
\end{tabular}




\begin{tabular}{|c|c|}
\hline $\mathrm{nL}$ & Nanolitre \\
\hline $\mathrm{nm}$ & Nanometre \\
\hline OIF & Ovulation-inducing factor \\
\hline PAGE & Polyacrylamide gel electrophoresis \\
\hline PANTHER & Protein Analysis THrough Evolutionary Relationships \\
\hline PI & Propidium iodide \\
\hline pg & Picogram \\
\hline PLS & Partial Least Squares \\
\hline pmol & Picomole \\
\hline ppm & Parts per million \\
\hline PRIDE & Proteomics Identifications \\
\hline PSPEP & Proteomics System Performance Evaluation Pipeline \\
\hline rpm & Revolutions per minute \\
\hline $\mathbf{s}$ & Seconds \\
\hline SDS & Sodium dodecyl sulfate \\
\hline SE & Standard error \\
\hline SP & Seminal plasma \\
\hline spz & Spermatozoa \\
\hline STR & Straightness index \\
\hline TB & Total number of kits born per litter \\
\hline TCG & Tris-citric acid-glucose \\
\hline TFA & Trifluoroacetic acid \\
\hline $\mathbf{x g}$ & G force \\
\hline $\mathbf{v}$ & Volt \\
\hline VAP & Average path velocity \\
\hline VCL & Average of curvilinear velocity \\
\hline vol & Volume \\
\hline $\mathbf{z}$ & Charge number of ions \\
\hline$\beta$-NGF & Beta-nerve growth factor \\
\hline 1D & One-dimension \\
\hline $\boldsymbol{\mu}$ & Micro \\
\hline
\end{tabular}


Micrograms

$\mu \mathrm{L}$

Microlitres

$\mu \mathrm{M}$

Micromolar

$\mu \mathrm{m}$

Micrometre

rmol

Micromol 


\section{I.GENERAL INTRODUCTION}





\section{I.GENERAL INTRODUCTION}

Rabbit (Oryctolagus cuniculus) is an important mammalian species worldwide, being at the same time of commercial interest and a research animal model. European rabbit meat production is approximately 500 thousand tons, corresponding to a $30 \%$ share of world production (Petracci et al., 2009). Besides, rabbits account for the seventh highest number of animals slaughtered per year in the European Union-27, with 347,603 × 1000 heads in 2014 (FAOSTAT, 2014).

\section{RABBIT ARTIFICIAL INSEMINATION}

Artificial insemination (Al) in rabbit dates from the late 80's (Vega et al., 2012), and as a consequence of its commercial development, reproductive control has experienced a great change in this species. The use of $\mathrm{Al}$ in intensive meat rabbit production is currently a common practice in many European countries, such as Italy, France and Spain. Al offers the same benefits for rabbit breeding as in other species in the control of genetic diversity, rapid upgrading of stock, establishment of pregnancies in females which refuse to mate, and avoidance of the spread of diseases (Morrell, 1995). In addition, Al permitted to develop a new system of production which consists in executing breeding operations on fixed days of the week allowing better production planning and reducing the needed of man power (Castellini, 1996). Furthermore, using $\mathrm{Al}$, an ejaculate from one male can be used to inseminate a large number of females and it has been proved that conception rates after $\mathrm{Al}$ with fresh semen are equivalent 
General introduction

to or even better than those obtained by natural mating (Daniel and Renard, 2010; Kitajima, 2009).

\section{OVULATION INDUCTION IN RABBIT DOES}

Mammalian species have been classified as either spontaneous or induced ovulators based on the type of stimulus responsible for eliciting $\mathrm{GnRH}$ (gonadotropin-releasing hormone) release from the hypothalamus (Bakker and Baum, 2000; Spies et al., 1997). In animals considered as spontaneous ovulators (e.g., women, cattle, horses, sheep, goat, pigs, monkeys and most rodents), ovulation is induced by ovarian steroid hormones at regular intervals (Bakker and Baum, 2000) (Figure I.1). Briefly, the ovarian follicular dynamic leads to the emergence of one or more dominant follicles (depending of species been monoparous or multiparous), which increases the systemic concentration of estradiol (El Allali et al., 2017). High estradiol concentration induces a positive feedback, which is permissive for the activation of $\mathrm{GnRH}$ release into the portal blood. GnRH in turn triggers a strong and transitory release of luteinizing hormone (LH) (LH surge) from the gonadotrophs of the pituitary gland (Bakker and Baum, 2000). This increase in circulating LH activates a whole cascade of inflammatory and proteolytic responses that leads to the rupture of the dominant follicular boundary wall and the ovulation of the oocyte. 
Figure I.1. Ovulation cycle of spontaneous ovulators.

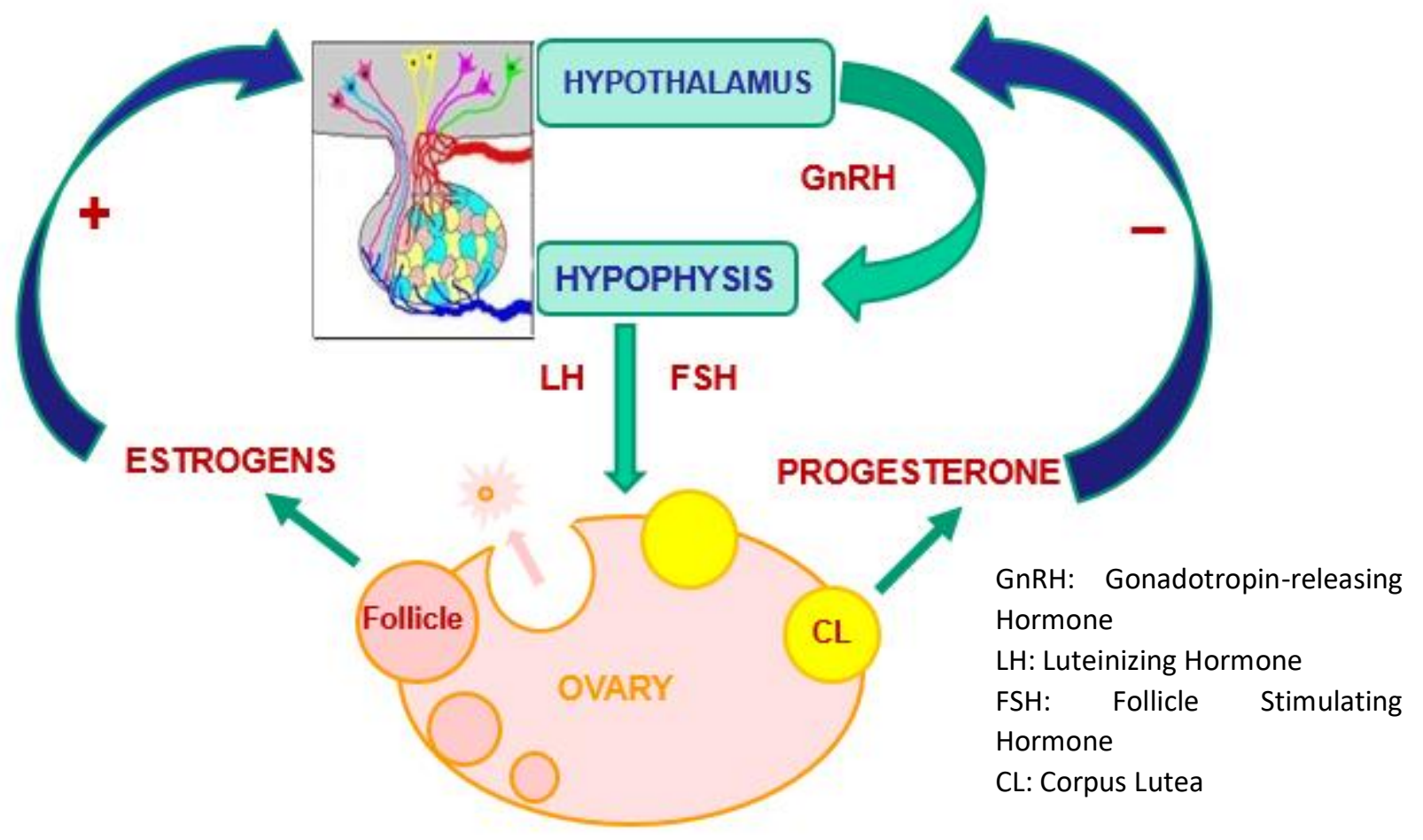

On the other hand, in induced or reflex ovulators (e.g., rabbit, Bactrian camel, llama, alpaca, cat, ferret), physical stimulation of the genitalia during copulation is the primary trigger for inducing ovulation (Adams et al., 2016), while the positive feedback action of estradiol is reduced or absent (El Allali et al., 2017) (Fig. I.2). It has been suggested that genital-somatosensory signals generated by penile intromission during copulation activate neural circuitries, mainly noradrenergic neurons, in the midbrain and brainstem to promote $\mathrm{GnRH}$ release (Bakker and Baum, 2000). In rabbits, a short mating bout including ejaculation induces genital somatosensory cues that contribute to the activation on $\mathrm{GnRH}$ neurons and the consequential generation of a preovulatory LH surge from the pituitary gland (Rebollar et al., 2012). Plasma LH levels start to rise within 3 minutes after mating and reach a plateau within 15 to 75 minutes (Jones et al., 1976). 
Figure I.2. Ovulation cycle of reflex ovulators.

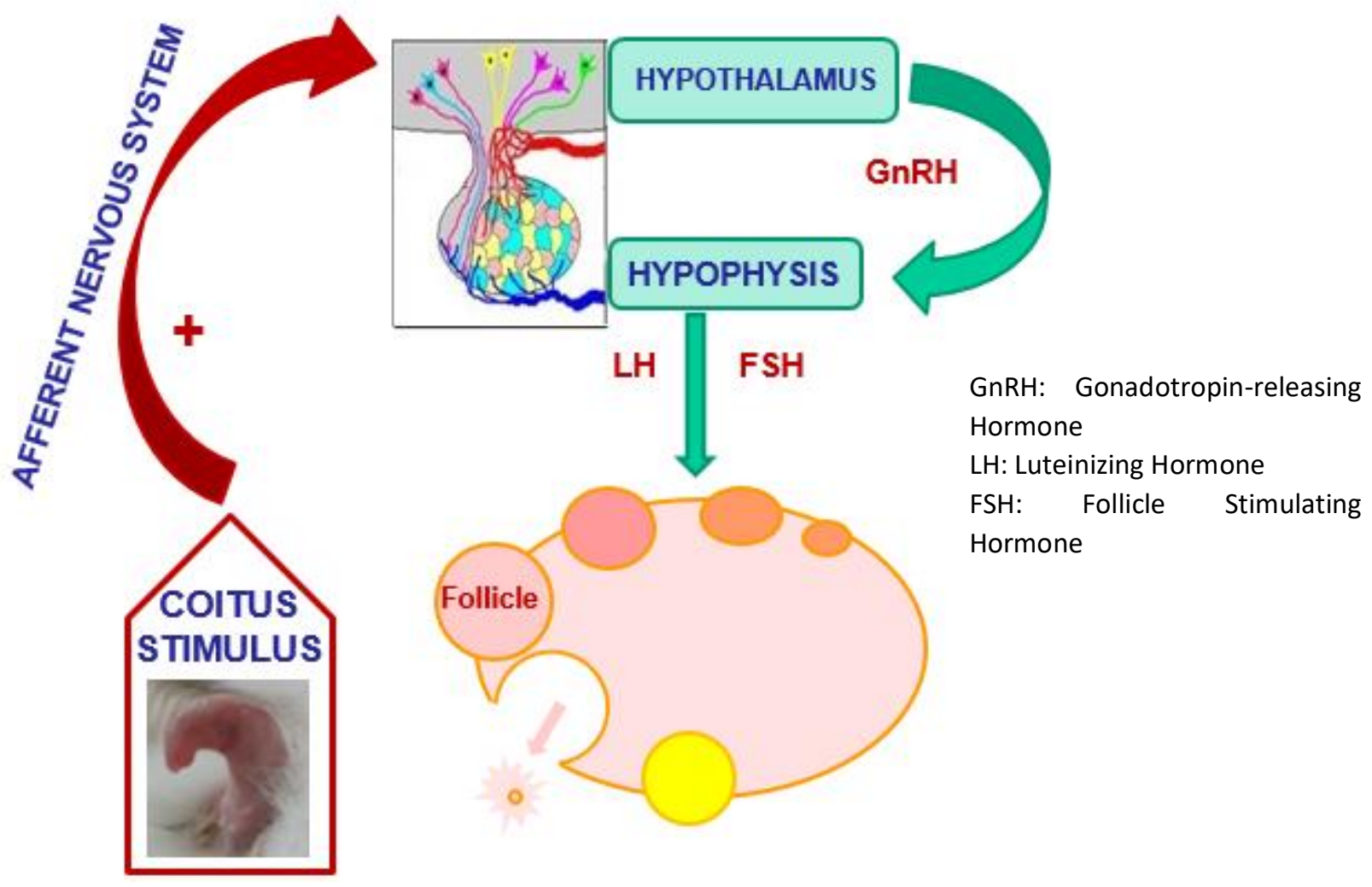

Recent llama and alpaca studies have clearly showed that ovulation in these reflex ovulators species can be also induced by a protein factor present in seminal plasma (Silva et al., 2015). The first evidence of an ovulation-inducing factor (OIF) in semen came from workers in China who concluded that some factor in the semen was responsible for eliciting ovulation in Bactrian camels, rather than the mechanical stimulation of copulation (Adams et al., 2016). Recently, the OIF has been identified as ßeta-nerve growth factor protein ( $\beta$-NGF) in the seminal plasma of alpaca (KershawYoung et al., 2012), llama (Ratto et al., 2012) and camel (Kumar et al., 2013). This nerve growth factor is a highly conserved protein of about $14 \mathrm{kDa}$ (Fig. I.3), capable of inducing ovulation when administered intramuscularly to alpaca, llama and camel 
females (Kershaw-Young et al., 2012; Silva et al., 2015; Berland et al., 2016; Adams et al., 2016; El Allali et al., 2017).

Figure 1.3. Protein structure of ovulation-inducing factor (OIF) from llama seminal plasma. (A) Monomer of OIF. (B) Biological dimer of OIF.

(Ratto et al., 2012)
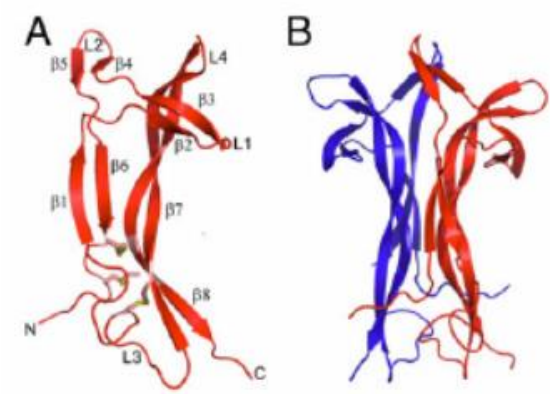

The mechanism and sites of action of $\beta$-NGF in the hypothalamus-pituitary-gonadal axis are as yet unclear, but the abundance of NGF in seminal plasma and the effects of seminal plasma on ovarian function strongly support the idea of an endocrine mode of action after being absorbed by the genital mucosa into circulation (Adams et al., 2016). $\beta$-NGF quantity in reflexively ovulating species such as llamas and alpacas is abundant and represents the $30 \%$ of the total seminal plasma protein content ( $20 \mathrm{mg} /$ ejaculate) (Berland et al., 2016). The semen of most mammals such as cattle, sheep, pig and horse also contains $\beta$-NGF (Bogle et al., 2011; Druart et al., 2013), however, $\beta$-NGF concentration is greater in induced as compared to spontaneous ovulators (El Allali et al., 2017). In rabbits, the intramuscular administration of seminal plasma does not provoke ovulation in rabbit does (Silva et al., 2011), but the study of this protein is interesting because it may exert a role in promoting the formation and development of the testis and the differentiation, maturation, and movement of the spermatozoa (Li et al., 2010). Moreover, NGF and its two receptors were reported to be expressed in the testis, prostate gland and seminal vesicle of rabbit, suggesting a possible role of this factor in the testicular development and spermatogenesis (Maranesi et al., 2015). 


\section{NEW EXTENDERS FOR RABBIT ARTIFICIAL INSEMINATION}

For over a century, it has been well known that ovulation is induced by coitus in the rabbit (Heape, 1905). Therefore, when using artificial insemination, the administration of a $\mathrm{GnRH}$ analogue is mandatory to induce doe ovulation due to the lack of nervous stimuli evoked by the male. This treatment requires an intramuscular injection, which can result in stress to the animal and additional work for the farm operators (Dal Bosco et al., 2011). Moreover, in most rabbit farms, GnRH injection is usually performed by the farmer, with a certain risk of misuse, and increasing the time needed for the artificial insemination of each doe (Quintela et al., 2009). Recent studies have investigated the possibility of ovulation induction in rabbits by vaginal absorption after supplementation of the seminal dose with $\mathrm{GnRH}$ synthetic analogues and tested their reproductive performance (Table I.1).

There are clear breeding advantages of intravaginal administration of $\mathrm{GnRH}$ analogues, such as less treatment distress, labor for the operators and operating time, but unfortunately, the concentration of $\mathrm{GnRH}$ analogue to be added to the seminal dose to achieve fertility results similar to those of intramuscular administration is much higher than the amount administered intramuscularly (Viudes-de-Castro et al., 2014). For this reason, in order to obtain fertility rates comparable with those obtained with the usual intramuscular injection, the intravaginal buserelin dose has to be at least 15 -fold higher (Quintela et al., 2009), becoming a potential health risk for farmers. 
Table I.1. Fertility and prolificacy rates of rabbits does induced to ovulate with different GnRH analogues added to the seminal dose.

\begin{tabular}{|c|c|c|c|c|}
\hline GnRH analogue ( $\mu \mathrm{g} / \mathrm{doe})$ & $\begin{array}{l}\text { Sperm concentration } \\
\left(\times 10^{6} \mathrm{spz} / \text { doe }\right)\end{array}$ & Fertility rate (\%) & $\begin{array}{l}\text { Prolificacy rate } \\
\text { (Mean) }\end{array}$ & References \\
\hline $\begin{array}{l}\text { Buserelin }(8,12,16) \\
\text { Control i.m. }(0.8)\end{array}$ & 30 & $\begin{array}{c}79.2,87.0,87.5 \% \\
91.7 \%\end{array}$ & $\begin{array}{c}9.9,9.7,11.7 \\
9.4\end{array}$ & Quintela et al., 2004 \\
\hline $\begin{array}{l}\text { Triptorelin (5) } \\
\text { Buserelin (5) } \\
\text { Control i.m. (1) }\end{array}$ & 6 & $\begin{array}{l}68.4 \% \\
74.8 \% \\
78.6 \%\end{array}$ & $\begin{array}{c}9.6 \\
10.1 \\
9.9\end{array}$ & $\begin{array}{l}\text { Viudes-de-Castro et } \\
\text { al., } 2007\end{array}$ \\
\hline $\begin{array}{l}\text { Buserelin (5) } \\
\text { Control i.m. (1) }\end{array}$ & - & $\begin{array}{l}76.0 \% \\
86.4 \%\end{array}$ & $\begin{array}{l}10.3 \\
10.4\end{array}$ & Vicente et al., 2008 \\
\hline $\begin{array}{c}\text { GnRH-Lecirelinum }(2.5,5,7.5,15) \\
\text { Control i.m. }(2.5)\end{array}$ & $24-95.2$ & $\begin{array}{c}42.99,59.97,72.09,52.77 \% \\
62.74 \%\end{array}$ & $\begin{array}{c}8.79,8.82,9.25,9.10 \\
9.03\end{array}$ & $\begin{array}{l}\text { Ondruška et al., } \\
2008\end{array}$ \\
\hline $\begin{array}{l}\text { [des-Gly 10, o-Ala6]-LHRH ethylamide }(25,30) \\
\text { Control i.m. (20) }\end{array}$ & 30 & $\begin{array}{l}82.8,73.3 \% \\
80.6 \%\end{array}$ & $\begin{array}{c}10.29,10.41 \\
10.96\end{array}$ & Quintela et al., 2009 \\
\hline Buserelin (5) & 12 & $74 \%$ & 9.0 & Vicente et al., 2011 \\
\hline $\begin{array}{l}\text { Lecilerin (5) } \\
\text { Control i.m. (5) }\end{array}$ & 10 & $\begin{array}{l}80 \% \\
80 \%\end{array}$ & - & $\begin{array}{l}\text { Dal Bosco et al., } \\
2014\end{array}$ \\
\hline $\begin{array}{c}\text { Buserelin (5) } \\
\text { Control i.m. (1) }\end{array}$ & 8 & $\begin{array}{l}58 \% \\
85 \%\end{array}$ & $\begin{array}{c}8.7 \\
10.4\end{array}$ & $\begin{array}{c}\text { Viudes-de-Castro et } \\
\text { al., } 2014\end{array}$ \\
\hline $\begin{array}{c}\text { [des-Gly 10, D-Ala6]-LHRH ethylamide }(5,10, \\
15) \\
\text { Control i.m. (1) }\end{array}$ & 25 & $\begin{array}{c}29.4,68.8,66.7 \% \\
72.2 \%\end{array}$ & $\begin{array}{c}10.1,9.2,9.7 \\
9.8\end{array}$ & Gogol, 2016a \\
\hline $\begin{array}{l}\text { Goserelin }(5,10) \\
\text { Leuprolide }(5,10) \\
\text { Control i.m. (1) }\end{array}$ & 25 & $\begin{array}{c}60.0,80.9 \% \\
54.2,75.0 \% \\
85.9 \%\end{array}$ & $\begin{array}{c}11.7,10.9 \\
10.7,10.9 \\
11\end{array}$ & Gogol, 2016b \\
\hline
\end{tabular}

Spz: spermatozoa; i.m.: intramuscular. 


\section{General introduction}

GnRH synthetic analogues can be absorbed via mucosa less efficiently than via parenteral (about five times less) (Viudes-de-Castro et al., 2007). The absorption of GnRH by vaginal mucosa is influenced by the state of the mucosa, the mucosal and sperm peptidase activity, the extender composition and the formulation of the analogue. Various approaches to improve protein delivery by vaginal route include: use of enzyme inhibitors, absorption enhancers, mucoadhesive polymers and/or novel carrier systems such as nanoparticles.

In rabbit, results from Vicente et al. (2011) showed that when buserelin acetate was added to seminal plasma diluted 1:5, a more marked decrease in ovulation frequency occurred than if it was diluted 1:20. This was due to the increased availability of GnRH analogue as a consequence of the reduction of the existing aminopeptidases. Recently, Viudes-de-Castro et al. (2014) showed that the bioavailability of buserelin acetate when added to the seminal dose appears to be determined by the activity of the existing seminal plasma aminopeptidases. This fact suggests that a possible solution to avoid using high hormone levels to induce ovulation effectively in rabbit could be the addition of protease or aminopeptidase inhibitors to semen extenders. This way, part of the enzyme activity that degrades the GnRH analogue would be inhibited and therefore, the bioavailability of the hormone would be higher.

Another possible approach in order to protect the hormone from enzyme degradation would be to encapsulate the GnRH analogue inside nanoparticles. Recently, proteins such as lutein, insulin, rhodamine $6 \mathrm{G}$ and bovine serum albumin (BSA) have been entrapped in nanoparticles of chitosan (CS) and dextran sulfate (DS) for their delivery in oral or ocular mucosa (Chen et al., 2007; Pechenkin et al., 2011; Chaiyasan et al., 2015). CS and DS are biodegradable, biocompatible and non-toxic polymers of natural 
origin with high adsorption capacity, which are widely used in pharmaceutical formulations (Chen et al., 2003, Domínguez-Delgado et al., 2014). In addition, they are polymers with multiple substituted negatively charged sulfate groups (in DS), or positively charged amine groups (deacetylated CS), and when mixed in aqueous solution, they form polyelectrolyte complexes through electrostatic interactions, better known as nanoparticles (Bader et al., 2015, Valente et al., 2013). CS-DS nanoparticles prepared by a coacervation process show promise as a system for controlled delivery of small and large molecules, including proteins (Chen et al., 2007), and they reduce the likelihood of their inactivation (Bader et al., 2015). In rabbits, an in vitro recent experience showed that the incubation of CS-DS nanoparticles with rabbit semen did not affect semen motility, viability nor membrane functionality, but improved acrosome integrity (Fernández-Serrano et al., 2017). Moreover, in the same study, a $40-50 \%$ of $\mathrm{GnRH}$ entrapment efficiency was achieved with CS-DS nanoparticles, meaning that the hormone was encapsulated and therefore protected.

\section{RABBIT GENETICS IN PRODUCTION}

Efficiency of rabbit meat production depends on several traits, which can be divided into production and reproduction related traits (Baselga and Blasco, 1989; Baselga, 2004). Production traits (growth, feed efficiency, carcass and meat traits) are relevant during fattening period and attributed to paternal lines, while reproduction traits (kindling interval, number of weaning kits, number of live young rabbits and longevity) are important for maternal lines (Naturil-Alfonso, 2016). Industrial rabbit production is based on a three-way crossbreeding scheme to exploit the complementarity of different synthetic breeds (lines) and makes use of heterosis or hybrid vigour (Simm, 


\section{General introduction}

1998). In rabbit, a first cross involves two maternal lines generating crossbred does. And a second cross consists of mating males of a third line, commonly selected for growth rate or weight at a given age, with the crossbred does to produce the rabbits to be slaughtered for meat (Baselga and Blasco, 1989). The final aim of the cross is to capitalize on the complementarity between reproductive and growth traits to produce large number of rabbits with fast growth and high feed efficiency (Baselga, 2004).

There are different rabbit genetic lines or breeds used in production such as $A$ and $R$ lines. Rabbit genetic line A is based on New Zealand White rabbits selected since 1980 by a family index for litter size at weaning over 45 generations (Fig. I.4 right). Whereas line $\mathrm{R}$ comes from the fusion of two lines, one founded in 1976 with Californian rabbits reared by Valencian farmers and another founded in 1981 with rabbits belonging to specialised paternal lines (Fig. I.1 left). The selection method was individual selection on post-weaning daily gain, with weaning taking place at 28 days and the end of the fattening at 63 days.

Figure I.4. Picture of rabbit genetic lines $\mathrm{R}$ (left) and $\mathrm{A}$ (right).

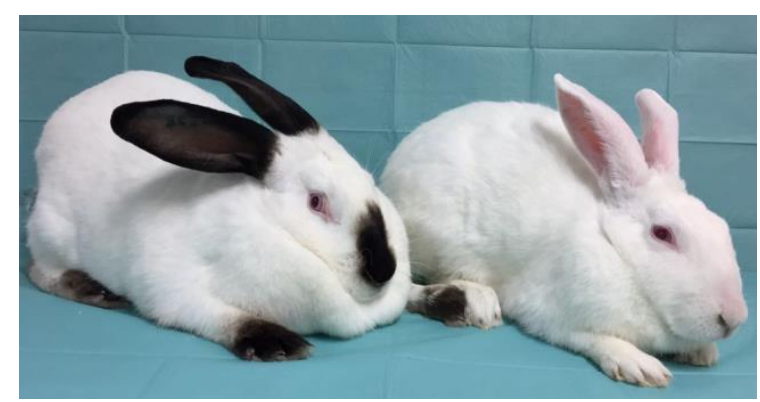

In rabbit, as in other species, selection for growth traits shows negative correlated responses in reproductive performance (Mgheni et al., 1985; Gómez et al., 1999; Ragab and Baselga, 2010). Several authors have compared the seminal characteristics 
and reproductive performance between these two genetic lines and have found differences (Vicente et al., 2000; Mocé et al., 2003; Safaa et al., 2008; Vicente et al., 2012). For instance, Vicente et al. (2000) found lower sperm production, less motility and more acrosomal defects in a paternal line selected for growth (line R) than in 3 maternal ones ( $\mathrm{V}, \mathrm{A}$ and $\mathrm{H}$ ). Mocé et al. (2003) showed a significantly lower fertilizing ability of line R sperm after being frozen by the same protocol than two maternal lines (A and V). In addition, Safaa et al. (2008) observed greater acrosome integrity, viability and percentage units for hypo-osmotic-swelling test in line A compared to line R. And finally, Vicente et al. (2012) found that the paternal line (R) had lowest ovulation frequency, number of implanted embryos, total born and live born than the maternal one (A).

\section{IMPORTANCE OF RABBIT BUCK IN REPRODUCTION}

In the rabbit industry, a single ejaculate can be divided into $20-50$ insemination doses for artificial insemination (Lavara et al., 2005). With Al, the impact of reproductive performance (i.e. male contribution to fertility and prolificacy) of individual males is vital (Piles et al., 2013).

Rabbit ejaculates present some peculiarities that should be taken into account, for instance, they present occasionally gel plug or gelatinous mass (Fig. I.5). Besides, rabbit seminal plasma contains several droplets and vesicles similar in size to spermatozoa that have been related to modulate different sperm functions such as motility, capacitation and acrosome reaction (Castellini et al., 2006, 2012, 2013; Collodel et al., 2012). 
Figure I.5. Gel plug of rabbit's ejaculate.

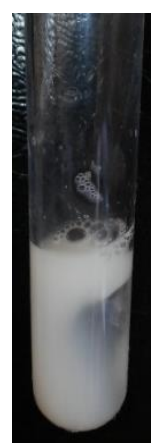

On the male side, the efficiency of Al depends on the efficient production of potentially fertile doses, which in turn, depends on quantitative semen production traits such as the sperm number per ejaculate and on quality characteristics that are potentially linked to the fertilising ability of the semen (Brun et al., 2016). In addition, the male genetic value should be considered because the maternal or growth traits have a direct effect on the productive traits of the offspring (Safaa et al., 2008). Many factors influence the production and quality of rabbit semen such as the genetic origin (growth lines have worse seminal qualities and fertility rates than maternal lines) (Vicente et al., 2000; Mocé et al., 2003; Safaa et al., 2008), the season (Marai et al., 2002; Pascual et al., 2004; Schneidgenová et al., 2011; Theau-Clément et al., 2015), the photoperiod (Roca et al., 2005; Ain-Baziz et al., 2012; Sabés-Alsina et al., 2015) and the collection frequency (Nizza et al., 2003). The production of fertile doses is determined by several components: i) male libido and characteristics of the ejaculate which form part of the criterion for ejaculate rejection; ii) volume and sperm concentration of the ejaculate (determining the amount of doses that can be obtained); and iii) the quality of sperm (determining the minimum sperm dosage required to ensure fertilization) (Piles et al., 2013). Subjective estimation of motility and evaluation of sperm morphology are the two laboratory assays most widely used for the rabbit semen evaluation in insemination centers (Lavara et al., 2005). However, the ability of these 
seminal characteristics to predict reproductive performance is very low (Piles et al., 2013). Consequently, new criteria for rabbit ejaculate selection are being explored, starting to focus on the sperm cell and on seminal plasma composition.

\subsection{Rabbit spermatozoa proteins}

New advances in proteomics are having a major impact on our understanding of how spermatozoa acquire their capacity for fertilization (Aitken and Baker, 2008). Sperm proteomics aims at the identification of the proteins that compose the sperm cell and the study of their function (de Mateo et al., 2013). The sperm cell is one of the most highly differentiated cells and is composed of a head with a highly compacted chromatin structure and a large flagellum with midpiece that contains the required machinery for movement and therefore to deliver the paternal genetic and epigenetic content to the oocyte (Codina et al., 2015). By being so highly differentiated, spermatozoa are advantageous cells to study proteomics of specific compartments such as the membrane, which basically is the area of major importance for its role in interacting with the surroundings and the oocyte (Rodríguez-Martínez et al., 2011). The fusion of a sperm and an oocyte is a sophisticated process that must be preceded by suitable changes in the sperm's membrane composition (Nowicka-Bauer and Kurpisz, 2013). Recent studies of spermatozoa from the proteomic point of view have allowed the identification of different proteins in spermatozoa that are responsible for the regulation of normal/defective sperm functions (Rahman et al., 2013).

While several techniques are available in proteomics, LC-MS (liquid chromatographymass spectrometry) based analysis of complex protein/peptide mixtures has turned 


\section{General introduction}

out to be a mainstream analytical technique for quantitative proteomics (Tuli et al., 2009). These advanced proteomics-related techniques constitute a powerful arsenal to study protein composition as well as their biological functions in cells, tissues and their secretions (Souza et al., 2012). Indeed, mass spectrometry-based proteomics has become the tool of choice for identifying and quantifying the proteome of an organism (Karpievitch et al., 2010), because of its exceptional sensitivity and resolving power that allow for the detection of proteins and peptides at low femtomole quantities (Wither et al., 2016).

Using LC-MS/MS, detailed proteomic data are now available for human (Baker et al., 2007), macaque (Skerget et al., 2013; Kawase et al., 2015), mouse (Baker et al., 2008a), rat (Baker et al., 2008b), ram (Pini et al., 2016), honeybee (Zareie et al., 2013), bull (Byrne et al., 2012; Ashrafzadeh et al., 2013; Somashekar et al., 2015), stallion (Swegen et al., 2015), fruit fly (Wasbrough et al., 2010), Caenorhabditis elegans (Ma et al., 2014), carp (Dietrich et al., 2016), chicken (Labas et al., 2015), rainbow trout (Nynca et al., 2014) and mussel (Zhang et al., 2015) sperm proteins. On the contrary, rabbit sperm proteome is not yet characterised, missing important information of potential proteins of interest which could improve breeding success in this agriculturally important animal.

\subsection{Rabbit seminal plasma proteins}

The general role of seminal plasma is to create an optimal environment for the storage of spermatozoa (Dietrich et al., 2014). Seminal plasma contributes to the safe environment for sperm maturation, sperm viability and fertilization in mammals (Kumar et al., 2013). In rabbits, seminal plasma has a positive effect in maintaining 
sperm motility and viability during in vitro storage (Castellini et al., 2000). Moreover, seminal plasma is a promising source for the study of potential reproductive biomarkers, because it is a complex mixture of secretions from testis, epididymis and male accessory sex glands (González-Cadavid et al., 2014). Species of mammals differ regarding the presence and size of accessory sexual glands, which obviously lead to variations in their relative contribution to semen composition and volume, particularly regarding seminal plasma (Rodríguez-Martínez et al., 2011).

A greater understanding of the proteins involved in reproduction can benefit human fertility and animal production (Bayram et al., 2016). The protein composition of mammalian seminal plasma varies among species, and has important effects on sperm function (Rodríguez-Martínez et al., 2011). These proteins participate in various events related to sperm function such as epididymal sperm maturation, sperm capacitation, sperm membrane stabilization and even the interaction with the oviduct and oocyte (Topfer-Petersen et al., 1998; Gwathmey et al., 2006). The diversity in the seminal plasma protein composition of different species of mammals may explain the variation in reproductive capacity and function (Druart et al., 2013).

In some species, seminal plasma proteins related to fertility (Killian et al., 1993; Brandon et al., 1999; Novak et al., 2010a, 2010b; Ashrafzadeh et al., 2013; Aslam et al., 2014), cold-shock damage sperm membrane resistance (Barrios et al., 2000; Pérez-Pé et al., 2001; Muiño-Blanco et al., 2008; Colás et al., 2009), sperm tolerance to freezing (Goularte et al., 2014; Rickard et al., 2015), freezability (Jobim et al., 2004, 2011; Zahn et al., 2005; Asadpour et al., 2007; Rego et al., 2016; Magalhães et al., 2016; Dietrich et al., 2017; Valencia et al., 2017) and semen quality (Cardozo et al., 2006; de Souza et al., 


\section{General introduction}

2007; Wang et al., 2009; Arruda-Alencar et al., 2012; Nandre et al., 2013; Kiso et al., 2013; Sarsaifi et al., 2015) have been identified.

Seminal plasma proteome of several animal species has been published during the past years (bull: Moura et al., 2010; ram: Souza et al., 2012; Pini et al., 2016; boar: Pérez-Patiño et al., 2016; carp: Dietrich et al., 2014; human: Pilch et al., 2006; Batruch et al., 2011, 2012; salmon: Gombar et al., 2017; honeybee: Baer et al., 2009; rainbow trout: Nynca et al., 2017). In the case of rabbit, seminal plasma proteins have been studied with a traditional 1D polyacrylamide gel (Viudes-de-Castro et al., 2004; Safaa et al., 2008) and with a 2D gel approach (Arruda-Alencar et al., 2012). In these previous studies, only two proteins were identified (Annexin 5 and Zeta globin-like). Therefore, a lack of information is missing regarding rabbit seminal plasma complete proteome identification.

\section{LITERATURE CITED}

Adams GP, Ratto MH, Silva ME, Carrasco RA. Ovulation-inducing factor (OIF/NGF) in seminal plasma: a review and update. Reprod. Domest. Anim. 2016;51(2):4-17.

Ain-Baziz H, Boulbina I, Ilès I, Belabbas R, Zenia S, Temim S. Influence of environmental temperature and relative humidity on semen characteristics in male rabbit (Oryctolagus cuniculus) of local Algerian population. In Proc: $10^{\text {th }}$ World Rabbit Congress, September 3 - 6, 2012- Sharm El- Sheikh -Egypt, 347-350.

Aitken RJ, Baker MA. The role of proteomics in understanding sperm cell biology. Int. J. Androl. 2008;31:295-302.

Arruda-Alencar JM, Viana-Neto AM, Souza CEA, Martins JAM, Moreno FB, Moreira $A C M$, et al. Major proteins of the seminal plasma of New Zealand white rabbits and 
association with semen criteria. $10^{\text {th }}$ World Rabbit Congress. Sharm El-Sheikh, Egypt: World Rabbit Science Association; 2012. p. 395-9.

Asadpour R, Alavi-Shoushtari S, Rezaii SA, Ansari MK. SDS-polyacrylamide gel electrophoresis of buffalo bulls seminal plasma proteins and their relation with semen freezability. Anim. Reprod. Sci. 2007;102:308-13.

Ashrafzadeh A, Nathan S, Karsani SA. Comparative analysis of Mafriwal (Bos taurusx Bos indicus) and Kedah Kelantan (Bos indicus) sperm proteome identifies sperm proteins potentially responsible for higher fertility in a tropical climate. International Journal of Molecular Sciences 2013;14:15860-77.

Aslam MM, Kumaresan A, Sharma VK, Tajmul M, Chhillar S, Chakravarty A, Manimaran A, Mohanty T, Srinivasan A, Yadav S. Identification of putative fertility markers in seminal plasma of crossbred bulls through differential proteomics. Theriogenology 2014;82:1254,1262.

Bader AR, Li T, Wang W, Kohane DS, Loscalzo J, Zhang YY. Preparation and characterization of SDF-1alpha-chitosan-dextran sulfate nanoparticles. J. Vis. Exp. 2015;(95):52323.

Baer B, Heazlewood JL, Taylor NL, Eubel H, Millar AH.The seminal fluid proteome of the honeybee Apis mellifera. Proteomics 2009;9:2085-97.

Baker MA, Reeves G, Hetherington L, Müller J, Baur I, Aitken RJ. Identification of gene products present in Triton $\mathrm{X}-100$ soluble and insoluble fractions of human spermatozoa lysates using LC-MS/MS analysis. Proteomics-Clinical Applications 2007;1:524-32. 


\section{General introduction}

Baker MA, Hetherington L, Reeves GM, Aitken RJ. The mouse sperm proteome characterized via IPG strip prefractionation and LC-MS/MS identification. Proteomics 2008a;8:1720-30.

Baker MA, Hetherington L, Reeves G, Müller J, Aitken RJ. The rat sperm proteome characterized via IPG strip prefractionation and LC-MS/MS identification. Proteomics 2008b;8:2312-21.

Barrios B, Pérez-Pé R, Gallego M, Tato A, Osada J, Muiño-Blanco T, Cebrián-Pérez JA. Seminal plasma proteins revert the cold-shock damage on ram sperm membrane. Biol. Reprod. 2000;63:1531-7.

Baselga M, Blasco A. Mejora Genética del Conejo de Producción de Carne. Ed MundiPrensa Libros SA, Madrid 1989.

Baselga M. Genetic improvement of meat rabbits.Programmes and diffusion. In: Proc. $8^{\text {th }}$ World Rabbit Congress, Puebla, Mexico, 2004:1-13.

Batruch I, Lecker I, Kagedan D, Smith CR, Mullen BJ, Grober E, Lo KC, Diamandis EP, Jarvi KA. Proteomic analysis of seminal plasma from normal volunteers and postvasectomy patients identifies over 2000 proteins and candidate biomarkers of the urogenital system. Journal of Proteome Research 2011;10:941-53.

Batruch I, Smith CR, Mullen BJ, Grober E, Lo KC, Diamandis EP, Jarvi KA.Analysis of seminal plasma from patients with non-obstructive azoospermia and identification of candidate biomarkers of male infertility. Journal of Proteome Research 2012;11:1503-11.

Bayram HL, Claydon AJ, Brownridge PJ, Hurst JL, Mileham A, Stockley P, Beynon RJ, Hammond DE.Cross-species proteomics in analysis of mammalian sperm proteins. Journal of Proteomics 2016;135:38-50. 
Bakker J, Baum MJ. Neuroendocrine regulation of GnRH release in induced ovulators. Front. Neuroendocrinol. 2000;21:220-62.

Berland MA, Ulloa-Leal C, Barria M, Wright H, Dissen GA, Silva ME, Ojeda SR, Ratto MH. Seminal plasma induces ovulation in llamas in the absence of a copulatory stimulus: role of nerve growth factor as an ovulation-inducing factor. Endocrinology 2016;157:3224-32.

Bogle OA, Ratto MH, Adams GP.Evidence for the conservation of biological activity of ovulation-inducing factor in seminal plasma. Reproduction 2011;142:277-83.

Brandon $\mathrm{Cl}$, Heusner $\mathrm{GL}$, Caudle $\mathrm{AB}$, Fayrer-Hosken RA.Two-dimensional polyacrylamide gel electrophoresis of equine seminal plasma proteins and their correlation with fertility. Theriogenology 1999;52:863-73.

Brun JM, Sanchez A, Ailloud E, Saleil G, Theau-Clement M. Genetic parameters of rabbit semen traits and male fertilising ability. Anim. Reprod. Sci. 2016;166:15-21.

Byrne K, Leahy T, McCulloch R, Colgrave ML, Holland MK. Comprehensive mapping of the bull sperm surface proteome. Proteomics 2012;12:3559-79.

Cardozo JA, Fernández-Juan M, Forcada F, Abecia A, Muiño-Blanco T, Cebrián-Pérez JA. Monthly variations in ovine seminal plasma proteins analyzed by two-dimensional polyacrylamide gel electrophoresis. Theriogenology 2006;66:841-50.

Castellini C. Recent advances in rabbit artificial insemination. In Proc: $6^{\text {th }}$ World Rabbit Congress, 9-12 July, Toulouse, France. 1996:2:13-26.

Castellini C, Lattaioli P, Moroni M, Minelli A. Effect of seminal plasma on the characteristics and fertility of rabbit spermatozoa. Anim. Reprod. Sci. 2000;63:27582. 


\section{General introduction}

Castellini C, Cardinali R, Dal Bosco A, Minelli A, Camici O. Lipid composition of the main fractions of rabbit semen. Theriogenology 2006;65(4):703-12.

Castellini C, Mourvaki E, Cardinali R, Collodel G, Lasagna E, Del Vecchio MT, Dal Bosco

A. Secretion patterns and effect of prostate-derived granules on the sperm acrosome reaction of rabbit buck. Theriogenology 2012;78(4):715-23.

Castellini C, Mattioli S, Ruggeri S, Dal Bosco A, Collodel G. The time-dependent effects of prostate granules and seminal plasma on the capacitation, acrosome reaction, and motility of rabbit sperm. Anim. Reprod. Sci. 2013;140(1-2):97-102.

Chaiyasan W, Srinivas SP, Tiyaboonchai W. Crosslinked chitosan-dextran sulfate nanoparticle for improved topical ocular drug delivery. Mol. Vis. 2015;21:1224-34.

Chen Y, Mohanraj VJ, Parkin JE. Chitosan-dextran sulfate nanoparticles for delivery of an anti-angiogenesis peptide. Lett. Peptide Sci. 2003;10:621-9.

Chen Y, Mohanraj VJ, Wang F, Benson HA. Designing chitosan-dextran sulfate nanoparticles using charge ratios. AAPS Pharm. Sci. Tech. 2007;8:E98.

Codina M, Estanyol JM, Fidalgo MJ, Ballescà JL, Oliva R. Advances in sperm proteomics: best-practise methodology and clinical potential. Expert review of proteomics 2015;12:255-77.

Colás C, Junquera C, Pérez-Pé R, Cebrián-Pérez JA, Muiño-Blanco T. Ultrastructural study of the ability of seminal plasma proteins to protect ram spermatozoa against cold-shock. Microsc. Res. Tech. 2009;72:566-72.

Collodel G, Cardinali R, Moretti E, Mattioli S, Ruggeri S, Castellini C. Role of rabbit prostate granules on sperm viability and acrosome reaction evaluated with different methods. Theriogenology 2012;77(5):1021-6.

Dal Bosco A, Rebollar PG, Boiti C, Zerani M, Castellini C. Ovulation induction in rabbit 
does: current knowledge and perspectives. Anim. Reprod. Sci. 2011;129:106-17.

Dal Bosco A, Cardinali R, Brecchia G, Rebollar PG, Fatnassi M, Millan P, Mattioli S, Castellini C. Induction of ovulation in rabbits by adding Lecirelin to the seminal dose: in vitro and in vivo effects of different excipients. Anim. Reprod. Sci. 2014;150:44-9. Daniel N, Renard JP. Artificial insemination in rabbits. Cold Spring Harbor Protocols 2010(1):pdb.prot5358.

de Mateo S, Estanyol JM, Oliva R. Methods for the analysis of the sperm proteome. Spermatogenesis: Methods and Protocols 2013:411-22.

de Souza FF, Barreto CS, Lopes MD. Characteristics of seminal plasma proteins and their correlation with canine semen analysis. Theriogenology 2007;68:100-6.

Dietrich MA, Dietrich GJ, Mostek A, Ciereszko A. Motility of carp spermatozoa is associated with profound changes in the sperm proteome. Journal of Proteomics 2016;138:124-35.

Dietrich MA, Arnold GJ, Nynca J, Frohlich T, Otte K, Ciereszko A. Characterization of carp seminal plasma proteome in relation to blood plasma. Journal of Proteomics 2014;98:218-232.

Dietrich MA, Irnazarow I, Ciereszko A. Proteomic identification of seminal plasma proteins related to the freezability of carp semen. Journal of Proteomics 2017;162:52-61.

Domínguez-Delgado CL, Rodríguez-Cruz IM, Fuentes-Prado E, Escobar-Chávez JJ, Vidal-Romero G, García-González L, Puente-Lee RI. Drug carrier systems using chitosan for non-parenteral routes. Pharmacology and Therapeutics: Intech; 2014. Druart X, Rickard JP, Mactier S, Kohnke PL, Kershaw-Young CM, Bathgate R, Gibb Z, Crossett B, Tsikis G, Labas V, Harichaux G, Grupen CG, de Graaf SP. Proteomic 


\section{General introduction}

characterization and cross species comparison of mammalian seminal plasma. Journal of Proteomics 2013;91:13-22.

El Allali K, El Bousmaki N, Ainani H, Simonneaux V. Effect of the camelid's seminal plasma ovulation-inducing factor/beta-NGF: a kisspeptin target hypothesis. Front. Vet. Sci. 2017;4:99.

FAOSTAT. 2014. Food and Agriculture Organization of the United Nations. Available at http://www.fao.org/faostat/en/\#data/QL.Last access. July 2017.

Fernández-Serrano P, Casares-Crespo L, Viudes-de-Castro MP. Chitosan-dextran sulfate nanoparticles for GnRH release in rabbit insemination extenders. Reprod. Domest. Anim. 2017;52(4):72-74.

Gogol P. Reproductive performance of rabbit does artificially inseminated with semen supplemented with GnRH analogue [des-Gly10, D-Ala6]-LH-RH ethylamide. Pol. J. Vet. Sci. 2016a;19:659-61.

Gogol P. Effect of goserelin and leuprolide added to the semen on reproductive performance in rabbits - Short communication. Acta Vet. Hung. 2016b;64:116-9.

Gombar R, Pitcher TE, Lewis JA, Auld J, Vacratsis PO. Proteomic characterization of seminal plasma from alternative reproductive tactics of Chinook salmon (Oncorhynchus tswatchysha). Journal of Proteomics 2017;157:1-9.

Gómez EA, Baselga M, Rafel O, García ML, Ramón J. Selection, diffusion and performances of six Spanish lines of meat rabbit. Cahiers Options Méditerranéennes 1999;41:147-152.

González-Cadavid V, Martins JA, Moreno FB, Andrade TS, Santos AC, Monteiro-Moreira AC, Moreira RA, Moura AA.Seminal plasma proteins of adult boars and correlations with sperm parameters.Theriogenology 2014;82:697-707. 
Goularte KL, Gastal GD, Schiavon RS, Goncalves AO, Schneider JR, Corcini CD, Lucia Jr T. Association between the presence of protein bands in ram seminal plasma and sperm tolerance to freezing. Anim. Reprod. Sci. 2014;146:165-9.

Gwathmey TM, Ignotz GG, Mueller JL, Manjunath P, Suarez SS. Bovine seminal plasma proteins PDC-109, BSP-A3, and BSP-30-kDa share functional roles in storing sperm in the oviduct. Biol. Reprod. 2006;75:501-7.

Heape W. Ovulation and degeneration of ova in the rabbit.Proceedings of the Royal Society of London. Series B, Containing Papers of a Biological Character $1905 ; 76: 260-8$

Jobim M, Oberst E, Salbego C, Souza D, Wald V, Tramontina F, Mattos R. Twodimensional polyacrylamide gel electrophoresis of bovine seminal plasma proteins and their relation with semen freezability. Theriogenology 2004;61:255-66.

Jobim MI, Trein C, Zirkler H, Gregory RM, Sieme H, Mattos RC. Two-dimensional polyacrylamide gel electrophoresis of equine seminal plasma proteins and their relation with semen freezability. Theriogenology 2011;76:765-71.

Jones EE, Bain JB, Odell WD. Postcoital luteinizing hormone release in male and female rabbits as determined by radioimmunoassay.Fertil.Steril. 1976;27:848-52.

Karpievitch YV, Polpitiya AD, Anderson GA, Smith RD, Dabney AR. Liquid Chromatography Mass Spectrometry-Based Proteomics: Biological and Technological Aspects. Ann. Appl. Stat. 2010;4:1797-823.

Kawase $\mathrm{O}$, Cao S, Xuan X. Sperm membrane proteome in wild Japanese macaque (Macaca fuscata) and Sika deer (Cervus nippon). Theriogenology 2015;83:95-102. 


\section{General introduction}

Kershaw-Young CM, Druart X, Vaughan J, Maxwell WM. Beta-Nerve growth factor is a major component of alpaca seminal plasma and induces ovulation in female alpacas. Reprod. Fertil. Dev. 2012;24:1093-7.

Killian GJ, Chapman DA, Rogowski LA. Fertility-associated proteins in Holstein bull seminal plasma. Biol. Reprod. 1993;49:1202-7.

Kiso WK, Selvaraj V, Nagashima J, Asano A, Brown JL, Schmitt DL, Leszyk J, Travis AJ, Pukazhenthi BS. Lactotransferrin in Asian elephant (Elephas maximus) seminal plasma correlates with semen quality. PloS one 2013;8:e71033.

Kitajima S. Improvement of rabbit production. In: Houdebine LM., Fan J. (eds) Rabbit Biotechnology. Springer, Dordrecht. 2009:3-12.

Kumar S, Sharma VK, Singh S, Hariprasad GR, Mal G, Srinivasan A, Yadav S. Proteomic identification of camel seminal plasma: purification of beta-nerve growth factor. Anim. Reprod. Sci. 2013;136:289-95.

Labas V, Grasseau I, Cahier K, Gargaros A, Harichaux G, Teixeira-Gomes A, Alves S, Bourin M, Gérard N, Blesbois E. Qualitative and quantitative peptidomic and proteomic approaches to phenotyping chicken semen. Journal of Proteomics 2015;112:313-35.

Lavara R, Mocé E, Lavara F, Viudes de Castro MP, Vicente JS. Do parameters of seminal quality correlate with the results of on-farm inseminations in rabbits? Theriogenology 2005;64:1130-41.

Li C, Sun Y, Yi K, Ma Y, Sun Y, Zhang W, Zhou X. Detection of nerve growth factor (NGF) and its specific receptor (TrkA) in ejaculated bovine sperm, and the effects of NGF on sperm function. Theriogenology 2010;74:1615-22. 
Ma X, Zhu Y, Li C, Xue P, Zhao Y, Chen S, Yang F, Miao L. Characterisation of Caenorhabditis elegans sperm transcriptome and proteome. BMC Genomics 2014;15:168.

Magalhães MJ, Martins LF, Senra RL, dos Santos TF, Okano DS, Pereira PRG, FariaCampos A, Campos SVA, Guimarães JD, Baracat-Pereira MC. Differential abundances of four forms of Binder of SPerm 1 in the seminal plasma of Bos taurus indicus bulls with different patterns of semen freezability. Theriogenology 2016;86:766,777.

Marai IFM, Habeeb AAM, Gad AE. Rabbits' productive, reproductive and physiological performance traits as affected by heat stress: a review. Livestock Production Science 2002;78(2):71-90.

Maranesi M, Zerani M, Leonardi L, Pistilli A, Arruda-Alencar J, Stabile AM, Rende M, Castellini C, Petrucci L, Parillo F, Moura A, Boiti C. Gene Expression and Localization of NGF and Its Cognate Receptors NTRK1 and NGFR in the Sex Organs of Male Rabbits. Reprod. Domest. Anim. 2015;50:918-25.

Mgheni M, Christensen K. Selection experiment on growth and litter size in rabbits: II. Two-way selection response for body weight at 112 days. Acta Agric. Scand. $1985 ; 35: 278-286$.

Mocé E, Vicente JS, Lavara R. Effect of freezing-thawing protocols on the performance of semen from three rabbit lines after artificial insemination. Theriogenology 2003;60:115-123.

Morrell JM. Artificial insemination in rabbits. British Veterinary Journal 1995;151(5):477-488. 
Moura AA, Souza CE, Stanley BA, Chapman DA, Killian GJ. Proteomics of cauda epididymal fluid from mature Holstein bulls. Journal of Proteomics 2010;73:200620.

Muiño-Blanco T, Pérez-Pé R, Cebrián-Pérez J. Seminal plasma proteins and sperm resistance to stress. Reproduction in Domestic Animals 2008;43:18-31.

Nandre RM, Fatima Sh, Bhupal G, Derashri HJ, Joshi CG.Assessment of variations in Indian Bubalus bubalis seminal plasma proteins during winter and summer seasons. Iranian Journal of Veterinary Research 2013;14(1):1-8.

Naturil-Alfonso C. Effect of feed restriction in a rabbit line selected for growth rate on reproductive performance: ovulation induction, oocyte quality, embryonary and fetal losses. Universidad Politécnica de Valencia. PhD Thesis 2016.

Nizza A, Di Meo C, Taranto S. Effect of Collection Rhythms and Season on Rabbit Semen Production. Reprod. Domest. Anim. 2003;38(6):436-439.

Novak S, Smith T, Paradis F, Burwash L, Dyck M, Foxcroft G, Dixon W. Biomarkers of in vivo fertility in sperm and seminal plasma of fertile stallions. Theriogenology 2010;74:956-67.

Novak S, Ruiz-Sánchez A, Dixon WT, Foxcroft GR, Dyck MK. Seminal plasma proteins as potential markers of relative fertility in boars. J. Androl. 2010;31:188-200.

Nowicka-Bauer K, Kurpisz M. Current knowledge of the human sperm proteome. Expert review of proteomics 2013;10:591-605.

Nynca J, Arnold GJ, Fröhlich T, Otte K, Ciereszko A. Proteomic identification of rainbow trout sperm proteins. Proteomics 2014;14:1569-73. 
Ondruška L, Parkányi V, Rafay J, Chlebec I. Effect of LHRH analogue included in seminal dose on kindling rate and prolificacy of rabbits artificially inseminated. In Proc: $9^{\text {th }}$ World Rabbit Science Congress, 10-13 June, Verona, Italy 2008:s.122:423-6.

Pascual JJ, García C, Martínez E, Mocé E, Vicente JS. Rearing management of rabbit males selected by high growth rate: the effect of diet and season on semen characteristics. Reprod. Nutr. Dev. 2004;44:49-63.

Pechenkin MA, Balabushevich NG, Zorov IN, Staroseltseva LK, Mikhalchik EV, Izumrudov VA, Larionova N. Design in vitro and in vivo characterization of chitosandextran sulfate microparticles for oral delivery of insulin. J. Bioequiv. Availab. 2011;3:244-50.

Pérez-Patiño C, Barranco I, Parrilla I, Valero ML, Martínez EA, Rodríguez-Martínez H, Roca J. Characterization of the porcine seminal plasma proteome comparing ejaculate portions. Journal of Proteomics 2016;142:15-23.

Pérez-Pé R, Cebrián-Pérez JA, Muiño-Blanco T. Semen plasma proteins prevent coldshock membrane damage to ram spermatozoa. Theriogenology 2001;56:425-34.

Petracci M, Bianchi M, Cavani C. Development of rabbit meat products fortified with $\mathrm{n}$ 3 polyunsaturated fatty acids. Nutrients 2009;1:111-8.

Pilch B, Mann M. Large-scale and high-confidence proteomic analysis of human seminal plasma. Genome Biol. 2006;7:R40.

Piles M, Tusell L, Lavara R, Baselga M. Breeding programmes to improve male reproductive performance and efficiency of insemination dose production in paternal lines: feasibility and limitations. World Rabbit Science 2013;21:61-75.

Pini T, Leahy T, Soleilhavoup C, Tsikis G, Labas V, Combes-Soia L, Harichaux G, Rickard JP, Druart X, de Graaf SP. Proteomic Investigation of Ram Spermatozoa and the 
General introduction

Proteins Conferred by Seminal Plasma. Journal of Proteome Research 2016;15:3700-11.

Quintela LA, Pena Al, Vega MD, Gullón J, Prieto C, Barrio M, Becerra JJ, Herradón PG. Reproductive performance of rabbit does artificially inseminated via intravaginal administration of [des-Gly 10, D-Ala6]-LHRH ethylamide as ovulation inductor. Reprod. Domest. Anim. 2009;44:829-33.

Quintela LA, Pena Al, Vega MD, Gullón J, Prieto MC, Barrio M, Becerra JJ, Maseda F, Herradón PG. Ovulation induction in rabbit does submitted to artificial insemination by adding buserelin to the seminal dose. Reprod. Nutr. Dev. 2004;44:79-88.

Ragab M, Baselga M. Inbreeding effect on reproductive traits in four maternal lines of rabbits. In Proc: $9^{\text {th }}$ World Congress on Genetics Applied to Livestock Production, 16 August, 2010. Leipzig, Germany. p. ID083

Rahman MS, Lee JS, Kwon WS, Pang MG. Sperm proteomics: road to male fertility and contraception. Int. J. Endocrinol. 2013;2013:360986.

Ratto MH, Leduc YA, Valderrama XP, van Straaten KE, Delbaere LT, Pierson RA, Adams GP. The nerve of ovulation-inducing factor in semen. Proc. Natl. Acad. Sci. USA 2012;109:15042-7.

Rebollar PG, Dal Bosco A, Millan P, Cardinali R, Brecchia G, Sylla L, Lorenzo PL, Castellini C. Ovulating induction methods in rabbit does: the pituitary and ovarian responses. Theriogenology 2012;77:292-8.

Rego J, Martins J, Wolf C, van Tilburg M, Moreno F, Monteiro-Moreira A, Moreira R, Santos D, Moura A. Proteomic analysis of seminal plasma and sperm cells and their associations with semen freezability in Guzerat bulls. J. Anim. Sci. 2016;94:5308-20. 
Rickard J, Leahy T, Soleilhavoup C, Tsikis G, Labas V, Harichaux G, Lynch G, Druart X, de Graaf S.The identification of proteomic markers of sperm freezing resilience in ram seminal plasma. Journal of Proteomics 2015;126:303-11.

Roca J, Martínez S, Orengo J, Parrilla I, Vázquez JM, Martínez, EA. Influence of constant long days on ejaculate parameters of rabbits reared under natural environment conditions of Mediterranean area. Livestock Production Science 2005;94:169-177.

Rodríguez-Martínez H, Kvist U, Ernerudh J, Sanz L, Calvete JJ. Seminal plasma proteins: what role do they play? American Journal of Reproductive Immunology 2011;66:1122.

Sabés-Alsina M, Planell N, Torres-Mejia E, Taberner E, Maya-Soriano MJ, Tusell L, Ramon J, Dalmau A, Piles M, Lopez-Bejar M. Daily exposure to summer circadian cycles affects spermatogenesis, but not fertility in an in vivo rabbit model. Theriogenology 2015;83:246-252.

Safaa HM, Vicente JS, Lavara R, Viudes de Castro MP. Semen evaluation of two selected lines of rabbit bucks. World Rabbit Science 2008;16:141-148.

Sarsaifi K, Haron AW, Vejayan J, Yusoff R, Hani H, Omar MA, Hong LW, Yimer N, Ju TY, Othman A. Two-dimensional polyacrylamide gel electrophoresis of Bali bull (Bos javanicus) seminal plasma proteins and their relationship with semen quality. Theriogenology 2015;84:956-68.

Schneidgenová M, Vašíček J, Čupka P, Chrenek P. Is it necessary to control seasonal quality of the rabbit ejaculate? Slovak J. Anim. Sci. 2011;44(2):48-51.

Silva M, Fernández A, Ulloa-Leal C, Adams G, Berland M, Ratto M. LH release and ovulatory response after intramuscular, intravenous, and intrauterine 


\section{General introduction}

administration of $\beta$-nerve growth factor of seminal plasma origin in female llamas. Theriogenology 2015;84:1096-102.

Silva M, Nino A, Guerra M, Letelier C, Valderrama XP, Adams GP, Ratto MH. Is an ovulation-inducing factor (OIF) present in the seminal plasma of rabbits? Anim. Reprod. Sci. 2011;127:213-21.

Simm G. Genetic Improvement of Cattle and Sheep. Ipswich: Farming Press 1998.

Skerget S, Rosenow M, Polpitiya A, Petritis K, Dorus S, Karr TL. The Rhesus macaque (Macaca mulatta) sperm proteome. Mol. Cell. Proteomics 2013;12:3052-67.

Somashekar L, Selvaraju S, Parthipan S, Ravindra JP. Profiling of sperm proteins and association of sperm PDC-109 with bull fertility. Systems biology in reproductive medicine 2015;61:376-87.

Souza CE, Rego JP, Lobo CH, Oliveira JT, Nogueira FC, Domont GB, Fioramonte M, Gozzo FC, Moreno FB, Monteiro-Moreira AC, Figueiredo JR, Moura AA. Proteomic analysis of the reproductive tract fluids from tropically-adapted Santa Ines rams. Journal of Proteomics 2012;75:4436-56.

Spies HG, Pau KY, Yang SP. Coital and estrogen signals: a contrast in the preovulatory neuroendocrine networks of rabbits and rhesus monkeys. Biol. Reprod. $1997 ; 56: 310-9$

Swegen A, Curry BJ, Gibb Z, Lambourne SR, Smith ND, Aitken RJ. Investigation of the stallion sperm proteome by mass spectrometry. Reproduction 2015;149:235-44.

Theau-Clément M, Bolet G, Sanchez A, Saleil G, Brun JM.Some factors that influence semen characteristics in rabbits. Anim. Reprod. Sci. 2015 Jun;157:33-8. 
Topfer-Petersen E, Romero A, Varela PF, Ekhlasi-Hundrieser M, Dostalova Z, Sanz L, Calvete JJ. Spermadhesins: a new protein family. Facts, hypotheses and perspectives. Andrología 1998;30:217-24.

Tuli L, Ressom HW. LC-MS Based Detection of Differential Protein Expression. J Proteomics Bioinform. 2009;2:416-38.

Valencia J, Gómez G, López W, Mesa H, Henao FJ. Relationship between HSP90a, NPC2 and L-PGDS proteins to boar semen freezability. Journal of animal science and biotechnology 2017;8:21.

Valente J, Gaspar V, Antunes B, Countinho P, Correia I. Microencapsulated chitosandextran sulfate nanoparticles for controled delivery of bioactive molecules and cells in bone regeneration. Polymer 2013;54:5-15

Vega MD, Barrio M, Quintela LA, Becerra JJ, Cainzos J, Prieto A, Rodríguez-Zamora A, Herradón PG. Reproductive management in rabbits. Información Técnica Económica Agraria (ITEA) 2012;108(2):172-190.

Vicente JS, Viudes de Castro MP, Lavara R, Lavara F. Effect of male line on prolificacy from does inseminated with low sperm doses. In Proc: $7^{\text {th }}$ World Rabbit Congress, 47 July 2000, Valencia, Spain. 2000;Vol A: 273-277.

Vicente JS, Lavara R, Lavara F, Marco-Jiménez F, Viudes-de-Castro MP. Rabbit reproductive performance after insemination with buserelin acetate extender.Livestock Science 2008;115:153-7.

Vicente JS, Lavara R, Marco-Jiménez F, Viudes-de-Castro MP. Detrimental effect on availability of buserelin acetate administered in seminal doses in rabbits. Theriogenology 2011;76:1120-5. 


\section{General introduction}

Vicente JS, Llobat L, Viudes-de-Castro MP, Lavara R, Baselga M, Marco-Jiménez F. Gestational losses in a rabbit line selected for growth rate. Theriogenology 2012;77: 81-88.

Viudes-de-Castro MP, Marco-Jiménez F, Vicente JS, Navarro E, Lavara R, Mocé E. Sperm kinetic parameters and differences in seminal plasma composition among two rabbit lines. In Proc: $8^{\text {th }}$ Annual Conference of ESDAR. Reprod. Dom Anim. 2004;39,4, pp. 266 (Abstract P13). WARSAW Agricultural University, Polonia.

Viudes-de-Castro MP, Lavara R, Marco-Jiménez F, Cortell C, Vicente JS. Ovulation induced by mucosa vaginal absorption of buserelin and triptorelin in rabbit. Theriogenology 2007;68:1031-6.

Viudes-de-Castro MP, Mocé E, Lavara R, Marco-Jiménez F, Vicente JS. Aminopeptidase activity in seminal plasma and effect of dilution rate on rabbit reproductive performance after insemination with an extender supplemented with buserelin acetate. Theriogenology 2014;81:1223-8.

Wang J, Wang J, Zhang HR, Shi HJ, Ma D, Zhao HX, Lin B, Li RS. Proteomic analysis of seminal plasma from asthenozoospermia patients reveals proteins that affect oxidative stress responses and semen quality. Asian J. Androl. 2009;11:484-91.

Wasbrough ER, Dorus S, Hester S, Howard-Murkin J, Lilley K, Wilkin E, Polpitiya A, Petritis K, Karr TL. The Drosophila melanogaster sperm proteome-II (DmSP-II). Journal of Proteomics 2010;73:2171-85.

Wither MJ, Hansen KC, Reisz JA. Mass spectrometry-based bottom-up proteomics: sample preparation, LC-MS/MS analysis, and database query strategies. Curr.Protoc. Protein Sci. 2016;86(16):4.1-16.4.20. 
Zareie R, Eubel H, Millar AH, Baer B. Long-term survival of high quality sperm: insights into the sperm proteome of the honeybee Apis mellifera. Journal of Proteome Research 2013;12:5180-8.

Zhang Y, Mu H, Lau SC, Zhang Z, Qiu J. Sperm proteome of Mytilus galloprovincialis: Insights into the evolution of fertilization proteins in marine mussels. Proteomics 2015;15:4175-9.

Zahn FS, Papa FO, Melo CM, Brisola ML. Protein profile of equine seminal plasma: correlation to semen freezability. Anim. Reprod. Sci. 2005;89:313-5. 

II.OBJECTIVES 



\section{II.OBJECTIVES}

The general aims of this thesis were to develop new artificial insemination extenders supplemented with a $\mathrm{GnRH}$ analogue in order to induce doe ovulation and to characterise the proteomic profile of rabbit semen. To this end, the specific objectives of the thesis were as follows:

The first three chapters of the current thesis aimed to develop new artificial insemination extenders supplemented with different substances to increase GnRH analogue's bioavailability without affecting reproductive performance. Chapter I focused on supplementing the extenders with a protease inhibitors cocktail, whereas chapter II was conducted to study the effect of specific aminopeptidase inhibitors addition to insemination extenders. Finally, in chapter III, the objective was to test different GnRH concentrations in the extenders to check if the aminopeptidase inhibitors protected the hormone and to study the efficacy of new extenders with the hormone encapsulated in chitosan-dextran sulfate nanoparticles.

The objectives in chapters IV, V and VI were to identify and quantify for the first time the complete seminal plasma and sperm's protein profile of rabbit species. First by using a one-dimension (1D) polyacrylamide gel approach (chapter IV) and later with nano LC-MS/MS technique (chapters V and VI). 

III.CHAPTER I 



\section{III.CHAPTER I}

\section{Does the inclusion of protease inhibitors in the}

\section{insemination extender affect rabbit reproductive}

\section{performance?}

L. Casares-Crespo ${ }^{a}$, J.S. Vicente ${ }^{\text {b }}$, A.M. Talaván ${ }^{b}$ and M.P. Viudes-de-Castro ${ }^{a}$

a Centro de Investigación y Tecnología Animal-Instituto Valenciano de Investigaciones Agrarias (CITA-IVIA), Polígono La Esperanza no 100, 12400 Segorbe, Castellón, Spain

b Instituto de Ciencia y Tecnología Animal, Universidad Politécnica de Valencia, 46071 Valencia, Spain

Theriogenology. 2016;85(5):928-932 



\section{ABSTRACT}

The bioavailability of buserelin acetate when added to the seminal dose appears to be determined by the activity of the existing aminopeptidases. Thus, the addition of aminopeptidase inhibitors to rabbit semen extenders could be a solution to decrease the hormone degradation. This study was conducted to evaluate the effect of the protease activity inhibition on rabbit semen quality parameters and reproductive performance after artificial insemination. Seminal quality was not affected by the incubation with protease inhibitors, being the values of motility, viability and acrosome integrity not significantly different between the protease inhibitors and the control group. In addition, seminal plasma aminopeptidase activity was inhibited in a $55.1 \%$ by the protease inhibitors. On the other hand, regarding the effect of protease inhibitors on reproductive performance, our results showed that the presence of protease inhibitors affected the prolificacy rate $(9.2 \pm 0.26$ and $9.3 \pm 0.23$ vs. $8.2 \pm 0.22$ total born per litter for negative control, positive control and aminopeptidase inhibitors group, respectively; $p<0.05)$, having this group one kit less per delivery. We conclude that the addition of a wide variety of protease inhibitors in the rabbit semen extender negatively affects prolificacy rate. Therefore, the development of new extenders with specific aminopeptidase inhibitors would be one of the strategies to increase the bioavailability of $\mathrm{GnRH}$ analogues without affecting the litter size. 



\section{INTRODUCTION}

The addition of the GnRH synthetic analogues to the seminal dose is a welfareorientated method to induce ovulation in rabbits and in addition reduces the time spent by farmers (Dal Bosco et al., 2011). The success of this method depends on the enzymes present in the seminal plasma (Viudes-de-Castro et al., 2014), the status of the vaginal mucosa and on the extender composition (Dal Bosco et al., 2014). Consequently, to achieve similar fertility results, when the $\mathrm{GnRH}$ analogue is applied intravaginally, the required concentration is much higher than the one used intramuscularly. Results from Vicente et al. (2011) showed that when buserelin acetate was added to seminal plasma diluted 1:5, a more marked decrease in ovulation frequency occurred than if it was diluted 1:20. This was due to the increased availability of $\mathrm{GnRH}$ analogue as a consequence of the reduction of the existing aminopeptidases. Recently, Viudes-de-Castro et al. (2014) showed that the bioavailability of buserelin acetate when added to the seminal dose appears to be determined by the activity of the existing seminal plasma aminopeptidases. In addition, it has been observed that males selected for maternal characteristics showed significantly lower aminopeptidase activity than males selected for growth rate, suggesting that the genetic origin of rabbit male could determine the aminopeptidase concentration present in the seminal plasma (Viudes-de-Castro and Mocé, 2013). These facts suggest that a possible solution to avoid using high hormone levels to induce ovulation effectively in rabbit could be the addition of aminopeptidase inhibitors to semen extenders. This way, part of the enzyme activity that degrades the GnRH analogue would be inhibited and therefore, the bioavailability of the hormone would be higher. 
Chapter I

The aim of this study was to evaluate the effect of the inclusion of protease inhibitors in semen extender on in vitro rabbit semen quality parameters (motility, viability and acrosome status) and in vivo reproductive performance (fertility and prolificacy) after artificial insemination.

\section{MATERIALS AND METHODS}

Unless stated otherwise, all chemicals in this study were purchased from Sigma-Aldrich Química S.A (Madrid, Spain).

\section{Animals}

All animals were handled according to the principles of animal care published by Spanish Royal Decree 53/2013.

To study the effect of protease inhibitors on semen quality parameters, a total of 12 adult bucks belonging to a paternal rabbit line (Line R) were used. All males were kept individually in flat deck cages under $16 \mathrm{~h}$ light/ $8 \mathrm{~h}$ dark conditions at the experimental farm of the Animal Technology and Research Centre (CITA-IVIA, Segorbe, Castellón, Spain) and fed ad libitum with the same commercial diet (17.5\% crude protein, $2.3 \%$ ether extract, $16.8 \%$ crude fiber, $2.600 \mathrm{kcal} \mathrm{DE} / \mathrm{Kg}$ ) and had free access to water.

To study the effect of protease inhibitors on reproductive performance, commercial crossbreed does were inseminated on one commercial farm (Altura, Castellón, Spain) with semen from the 12 Line R adult males. A total of 709 artificial inseminations were performed. Receptive females were classified by physiological status as multiparous lactating does (more than two delivered births and eight or nine young rabbits suckled), multiparous non-lactating females (females with more than one delivery 
without suckling any young) and nulliparous females (females who have never given birth). Multiparous lactating does were inseminated 10 to 12 days after delivery. The sexual receptivity in multiparous does was obtained by closing the nest during $36 \mathrm{~h}$.

\section{In vitro effect of protease inhibitors on seminal quality}

\subsection{Semen collection and evaluation}

Two ejaculates per male were collected each week during 4 weeks using an artificial vagina, with a minimum of 30 minutes between ejaculate collections, on a single day. Sperm evaluation was performed to assess the initial seminal quality. Only ejaculates exhibiting a white colour and possessing motility rate higher than $70 \%$ were used in the experiment. Finally, the ejaculates were pooled. In total, four pools were used. In order to evaluate seminal quality aliquots of pooled semen were taken. A $20 \mu \mathrm{L}$ aliquot was diluted $1: 50$ with $0.25 \%$ glutaraldehyde solution to calculate the concentration and rate of abnormal sperm in a Thoma chamber by phase contrast at a magnification of 400X.

The motility characteristics of sperm (percentage of total and progressively motile sperm, evaluated using a computer-assisted sperm analysis system) were determined as described by Viudes-de-Castro et al. (2014). A spermatozoon was defined as nonmotile if the average path velocity (VAP) was $<10 \mu \mathrm{m} \mathrm{s}^{-1}$ and a spermatozoon was considered to be progressively motile when VAP was $>50 \mu \mathrm{m} \mathrm{s}^{-1}$ and the straightness index (STR) was $\geq 70 \%$.

Flow cytometric analyses to assess viability and acrosome integrity, were performed using a Coulter Epics XL cytometer (Beckman Coulter, IZASA, Barcelona, Spain). The fluorophores were excited by a $15 \mathrm{~mW}$ argon ion laser operating at $488 \mathrm{~nm}$. A total of 
Chapter I

10,000 gated events (based on the forward scatter and side scatter of the sperm population recorded in the linear mode) were collected per sample. Flow cytometric data were analyzed with the software Expo32ADC (Beckman Coulter Inc.). Samples were diluted to $30 \times 10^{6}$ sperm/mL with TCG extender (Viudes-de-Castro and Vicente, 1997) supplemented with $2 \mathrm{~g} / \mathrm{L}$ BSA. All the dilutions were performed at $22{ }^{\circ} \mathrm{C}$. The percentage of viable sperm was determined using a dual fluorescent staining with SYBR-14/PI according to Viudes-de-Castro et al. (2014). The status of the acrosome in each sample was determined using a dual fluorescent staining with FITC-PNA/PI. Diluted samples were stained by transferring $0.1 \mathrm{~mL}$ aliquots into tubes containing $0.45 \mathrm{~mL}$ of TCG, $1.5 \mu \mathrm{l}$ of fluorescein labeled lectin from the peanut plant Arachis hypogaea (FITC-PNA, $1 \mathrm{mg} / \mathrm{mL}$ solution in saline solution) and $2.5 \mu \mathrm{L}$ of PI $(1.5 \mathrm{mM}$ solution in purified water). They were incubated (10 minutes, $\left.22^{\circ} \mathrm{C}\right)$, filtered through a $40-\mu \mathrm{m}$ nylon mesh to remove large clumps of cells and debris. Fluorescence was measured using a FL-1 sensor, a $525 \mathrm{~nm}$ band-pass filter to detect FITC-PNA, and a FL-2 sensor and a $575 \mathrm{~nm}$ band-pass filter to detect PI. Four sperm sub-populations were detected: live acrosome intact, live acrosome damaged, dead acrosome intact and dead acrosome damaged. Percentage of normal apical ridge (NAR) was calculated as the proportion of acrosome intact sperm.

\subsection{Protease inhibitor activity evaluation}

In this experiment, two different extenders were tested: TCG (control) and an experimental extender containing TCG supplemented with Protease Inhibitor Cocktail (P2714, Sigma) diluted 1:100. The protease inhibitor cocktail used contains 4-(2Aminoethyl) benzenesulfonyl fluoride hydrochloride (AEBSF), aprotinin, bestatin, E-64, Ethylenediaminetetraacetic acid (EDTA) and leupeptin. Sperm samples were split into 
two equal fractions and diluted 1:20 with TCG (control) and supplemented TCG respectively. Fractions were stored two hours at room temperature $\left(20-25^{\circ} \mathrm{C}\right)$. Then, three aliquots of each sample were taken to measure the motility, the viability and the status of the acrosome again. The remaining pooled semen was used to measure alanyl peptidase (APN) activity.

\subsection{Seminal plasma preparation and measurement of APN activity}

Semen samples were centrifuged at $10.000 \times \mathrm{g}$ for $10 \mathrm{~min}$ at $22{ }^{\circ} \mathrm{C}$. The resulting supernatants were collected and centrifuged again $(10.000 \mathrm{x}$ g for $10 \mathrm{~min})$ to remove residual spermatozoa and cell debris. The resulting pellets were discarded, whereas the supernatants were stored at $-80^{\circ} \mathrm{C}$ until use.

APN activity in seminal plasma was determined according to Viudes-de-Castro et al. (2014). Briefly, samples were incubated with the substrate (alanine- $\beta$-naphthylamide) for $30 \mathrm{~min}$ at $37^{\circ} \mathrm{C}$, after which the reaction was stopped with $0.1 \mathrm{M}$ sodium acetate buffer ( $\mathrm{pH}$ 4.2). The release of $\beta$-naphthylamide as a result of enzyme activity was determined by measuring the fluorescence intensity at $460 \mathrm{~nm}$ with excitation at 355 $\mathrm{nm}$. Protein concentration of semen samples was measured using the bicinchoninic acid (BCA) method, using BSA as the standard (Smith et al., 1985). APN activity and protein concentration were measured in triplicate. The peptidase activity was expressed as pmol of $\beta$-naphthylamide released per milligram of protein per minute. In order to calculate the percentage of APN activity inhibition, the APN activity of the control group was used as reference in each case. 
Chapter I

\section{In vivo effect of protease inhibitors on reproductive performance}

\subsection{Semen collection and evaluation}

Each week, two ejaculates per male were collected, with a minimum of 30 minutes between ejaculate collections, on a single day using an artificial vagina. Sperm evaluation was performed to assess the initial seminal quality. Only ejaculates exhibiting a white colour and possessing more than $70 \%$ of motility rate, $85 \%$ of normal intact acrosome, and less than $15 \%$ of abnormal sperm were used in this experiment. All other ejaculates were discarded. The pools used in the experiment presented an average sperm concentration of 296 spermatozoa $\mathrm{mL}^{-1}$.

The remaining pooled semen was split into three aliquots and diluted 1:20 respectively with 1) TCG extender supplemented with $10 \mu \mathrm{g}$ of buserelin acetate/mL 2) TCG extender supplemented with the protease inhibitor (protease inhibitor cocktail dilution rate 1:100) and $10 \mu \mathrm{g}$ of buserelin acetate/mL and 3) TCG extender (non GnRHsupplemented).

\subsection{Insemination procedure}

A total of 709 inseminations were performed in six different days. Only receptive females (red colour of vulvar lips) were inseminated with $0.5 \mathrm{~mL}$ of semen using standard curved pipettes $(22 \mathrm{~cm})$. Each female was randomly assigned to one of the three experimental groups:

-Positive control group: does inseminated with $0.5 \mathrm{~mL}$ diluted semen in TCG. At the time of insemination, each female received an intramuscular injection of buserelin acetate to induce ovulation ( $1 \mu \mathrm{g}$ per doe).

-Negative control group: does inseminated with $0.5 \mathrm{~mL}$ diluted semen in supplemented extender with $10 \mu \mathrm{g} / \mathrm{mL}$ of buserelin acetate. 
-Protease inhibitors group: does inseminated with $0.5 \mathrm{~mL}$ diluted semen in supplemented extender with protease inhibitor cocktail (dilution rate 1:100) and 10 $\mu \mathrm{g} / \mathrm{mL}$ of buserelin acetate.

Fertility rate at birth (number of does giving birth/number of inseminated does) and prolificacy (number of total kits born) were reproductive performances considered.

\section{Statistical analysis}

Data were statistically evaluated with SPSS 16.0 library procedures (SPSS Inc., Chicago, Illinois, USA, 2002). To analyse the effect of the extender on motility, viability and acrosome integrity, an analysis of variance (ANOVA) was used. A probit link with binomial error distribution was used to analyse the fertility rate at birth, including as fixed effects the extender used and the physiological state of the females and their interactions. For total number of kits born per litter, a general linear model procedure (GLM) was performed, including as fixed effects the extender used and the physiological state of the females and their interactions. Means were separated using Fishers Least Significant Difference (LSD) test at a fixed 5\% error level and the results are presented as least square means values $(\mathrm{LSM}) \pm$ standard error of the mean (SE).

\section{RESULTS}

\section{Effect of protease inhibitors on seminal quality}

Results showed that the presence of protease inhibitors did not affect the motility, neither the viability nor the acrosome integrity of the seminal samples. The percentage of total motile sperm, percentage of progressively motile sperm, average of curvilinear velocity (VCL), mean amplitude of lateral head displacement (ALH), frequency of head 
Chapter I

displacement (BCF), linearity coefficient (LIN) and VAP were $90.4 \pm 2.1 \%, 50.4 \pm 5.8 \%$, $52.06 \pm 4.18 \mu \mathrm{m} / \mathrm{s}, \quad 2.42 \pm 0.10 \mu, \quad 10.0 \pm 0.28 \%, \quad 48.71 \pm 2.14 \%$ and $35.52 \pm 3.35 \mu \mathrm{m} / \mathrm{s}$ respectively (data not shown in tables). The values of viability and acrosome integrity after two hours of incubation with the two extenders were similar $(82.5 \pm 2.03$ of viability and $98.7 \pm 0.4 \%$ of normal apical ridge). On the other hand, the APN activity was inhibited in the extender containing the protease inhibitors cocktail. The APN activity was a $55.1 \%$ lower than the control extender.

\section{Effect of protease inhibitors in fertility and prolificacy}

Fertility rate at birth and prolificacy are presented in Table 1.1. These parameters were affected by the experimental group. Positive control group showed the highest fertility rate at birth while the fertility of females from groups with buserelin acetate in the seminal dose was reduced 19 and 15\% (negative control group and protease inhibitors group, respectively).

Regarding prolificacy, the total number of kits born per litter was affected by treatment $(p<0.05 ;$ Table 1.1). Does from the positive and the negative control group showed similar prolificacy rate. On the other hand, females from protease inhibitors group showed a significantly lower prolificacy than the other two groups.

Multiparous non-lactating and nulliparous does showed significantly higher fertility rate than the multiparous lactating does group $(0.77 \pm 0.02$ and $0.79 \pm 0.07$ vs. $0.65 \pm$ 0.03 , respectively; $p<0.05)$.

No interaction between experimental group and physiological status at the moment of insemination was observed. 
Table 1.1. Reproductive performance of inseminated does. (Least square means \pm standard error).

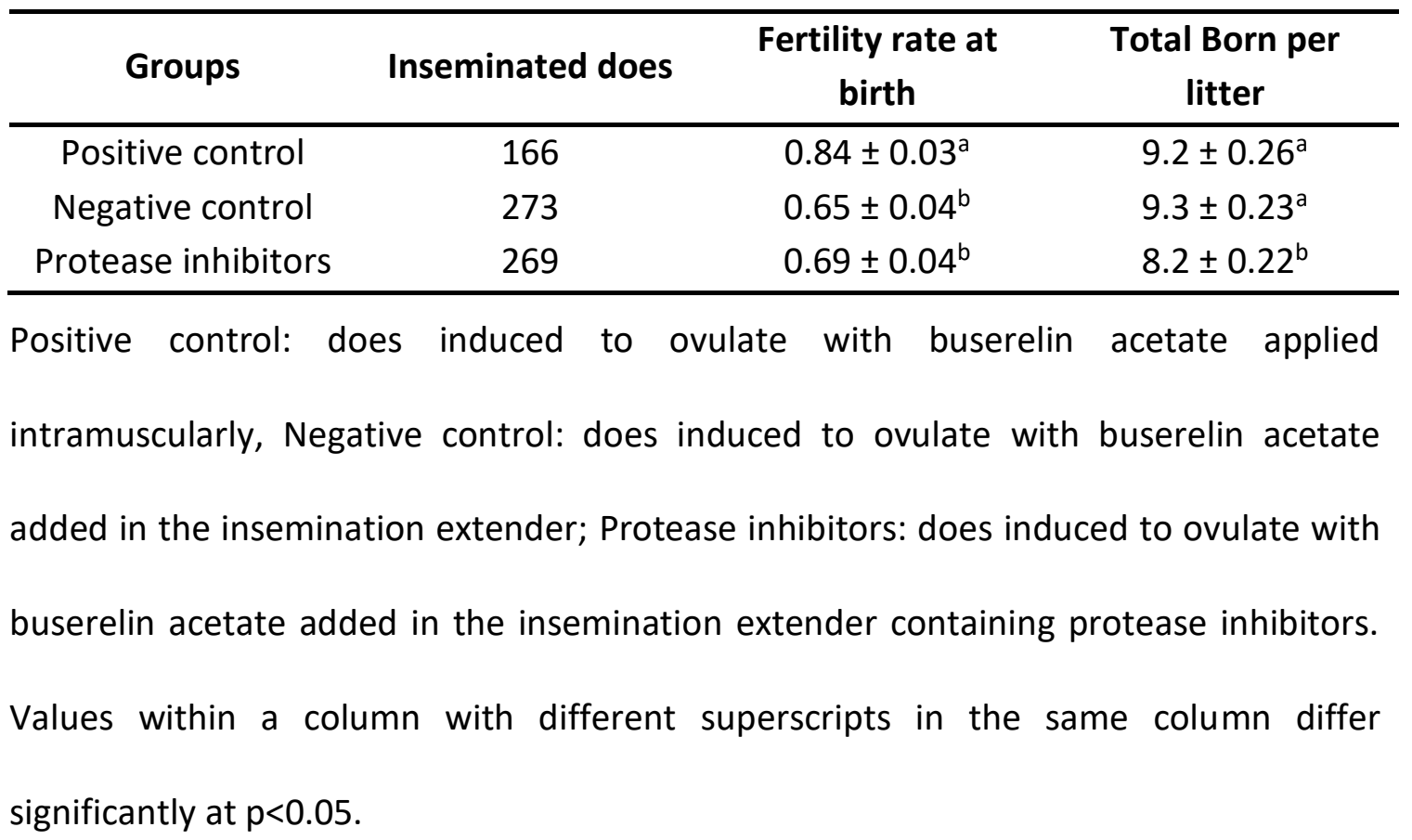

\section{DISCUSSION}

In this article, we have shown that rabbit semen extender affects neither semen quality nor fertility rate, but affects the prolificacy rate by decreasing the total number of kits born per litter.

In mammals, seminal plasma is a complex mixture of secretions from the epididymis and from the various accessory sex glands (La Falci et al., 2002). Its composition is designed to assure the successful fertilization of the oocyte and is characterized by a high abundance of proteins which play important roles in sperm survival and are involved in various events such as epididymal sperm maturation, sperm capacitation, sperm membrane stabilization, modulation of the uterine immune response, sperm transport in the female genital tract, gamete interaction and fusion and even 
pregnancy establishment (Okabe et al., 1993; Topfer-Petersen et al., 1998; Gwathmey et al., 2006; Rodríguez-Martínez et al., 2011; Laflamme et al., 2013). In human, the $60 \%$ of the seminal plasma proteome has enzymatic activity. The abundance of proteases and protease inhibitors in seminal plasma show the importance of this system in this body fluid (Pilch et al., 2006). Many enzymes, hormones and other physiologically active proteins are synthesized as inactive precursors that are converted to the active form by the action of specific proteases.

Because the protease inhibitor cocktail tested in this work contained a broad enzyme inhibition spectrum, it was predictable that the seminal quality, the fertilization process, or both, were affected.

Several studies have tested the effect of different protease inhibitors on mammal sperm in vitro quality and fertilization process. For instance, leupeptin had no effect in rabbit sperm motility (de Lamirande et al., 1986). In pig, spermatozoa incubated in medium with AEBSF were less motile after $6 \mathrm{~h}$ of incubation, yet progressive motility, VAP, VSL, acrosome status and mitochondrial potential remained unaltered (Beek et al., 2015). These results are consistent with ours, as seminal quality parameters were similar between control and protease inhibitors group after $2 \mathrm{~h}$ of incubation.

In the present work, the inclusion of protease inhibitors in semen extender affected only the prolificacy rate, having this group one kit less per delivery. This fact could be explained because proteases play an important role during mammalian fertilization, so the inhibition of a wide variety of proteases in this work, could have negatively affected this process. The part of the fecundation process affected by protease inhibitors seems to be species-specific. In guinea pig, the incubation of sperm with leupeptin inhibited the completion of the acrosomal reaction, but bestatin had no 
effect (Flaherty et al., 1993). In bovine sperm, the use of trypsin and chymotrypsin inhibitors, but not metalloproteases, were effective in inhibiting the acrosomal reaction process and in addition, sperm incubation with these proteases did not reveal statistically differences in the sperm zona pellucida binding capacity in relation to control sperm (Deppe et al., 2008). In pig, the effect of AEBSF on in vitro fertilization and polyspermy rates were a decreased by at least 50\% (Beek et al., 2015). In mouse and human, the use of specific serine proteases inhibitors decreases the fertilization rate (Fraser, 1982; Llanos et al., 1993). Finally, studies in sea urchin provide evidence for the involvement of metalloproteases in membrane fusion during the acrosome reaction (Farach et al., 1987).

Considering the results of the present study, we can conclude that the addition of a wide variety of protease inhibitors in the rabbit semen extender negatively affects the prolificacy rate. Therefore, the development of new extenders with specific aminopeptidase inhibitors would be one of the strategies to increase the bioavailability of $\mathrm{GnRH}$ analogues without affecting the litter size. In the future, the study of inhibitors individually will be necessary to define how to increase the GnRH bioavailability without affecting the fertilizing capacity of spermatozoa.

\section{REFERENCES}

Beek J, Maes D, Nauwynck H, Piepers S, Van Soom A. A critical assessment of the effect of serine protease inhibitors on porcine fertilization and quality parameters of porcine spermatozoa in vitro. Reprod. Biol. 2015;15(1):9-19. 
Dal Bosco A, Cardinali R, Brecchia G, Rebollar PG, Fatnassi M, Millan P. Induction of ovulation in rabbits by adding lecirelin to the seminal dose: In vitro and in vivo effects of different excipients. Anim. Reprod. Sci. 2014;150(1-2):44-9.

Dal Bosco A, Rebollar PG, Boiti C, Zerani M, Castellini C. Ovulation induction in rabbit does: Current knowledge and perspectives. Anim. Reprod. Sci. 2011;129(3-4):10617.

de Lamirande E, Gagnon C. Effects of protease inhibitors and substrates on motility of mammalian spermatozoa. J. Cell Biol. 1986;102(4):1378-83.

Deppe M, Morales P, Sanchez R. Effect of protease inhibitors on the acrosome reaction and sperm-zona pellucida binding in bovine sperm. Reprod. Domest. Anim. 2008;43(6):713-9.

Farach HA Jr, Mundy DI, Strittmatter WJ, Lennarz WJ. Evidence for the involvement of metalloendoproteases in the acrosome reaction in sea urchin sperm. J. Biol. Chem. $1987 ; 262(12): 5483-7$.

Flaherty SP, Swann NJ. Proteases are not involved in the membrane fusion events of the lysolecithin-mediated guinea pig sperm acrosome reaction. J. Cell. Sci. 1993;104:163-72.

Fraser LR. P-aminobenzamidine, an acrosin inhibitor, inhibits mouse sperm penetration of the zona pellucida but not the acrosome reaction. J. Reprod. Fertil. $1982 ; 65(1): 185-94$

Gwathmey TM, Ignotz GG, Mueller JL, Manjunath P, Suarez SS. Bovine seminal plasma proteins PDC-109, BSP-A3, and BSP-30-kDa share functional roles in storing sperm in the oviduct. Biol. Reprod. 2006;75(4):501-7. 
La Falci VS, Tortorella H, Rodrigues JL, Brandelli A. Seasonal variation of goat seminal plasma proteins. Theriogenology 2002;57(3):1035-48.

Laflamme BA, Wolfne MF. Identification and function of proteolysis regulators in seminal fluid. Molecular Reproduction and Development 2013;80:80-101.

Llanos M, Vigil P, Salgado AM, Morales P. Inhibition of the acrosome reaction by trypsin inhibitors and prevention of penetration of spermatozoa through the human zona pellucida. J. Reprod. Fertil. 1993;97(1):173-8.

Okabe M, Kishi Y, Ying X, Kohama Y, Mimura T, Li SS. Characterization of capacitation inhibitory protein from rabbit seminal plasma: Homology with human annexins. Biol. Pharm. Bull. 1993;16(5):453-6.

Pilch B, Mann M. Large-scale and high-confidence proteomic analysis of human seminal plasma. Genome Biology 2006; 7:R40.

Rodríguez-Martínez H, Kvist U, Ernerudh J, Sanz L, Calvete JJ. Seminal plasma proteins: what role do they play? Am. J. Reprod. Immunol. 2011;66(1):11-22.

Smith PK, Krohn RI, Hermanson GT, Mallia AK, Gartner FH, Provenzano MD. Measurement of protein using bicinchoninic acid. Anal. Biochem. 1985;150(1):7685.

Topfer-Petersen E, Romero A, Varela PF, Ekhlasi-Hundrieser M, Dostalova Z, Sanz L. Spermadhesins: A new protein family. Facts, hypotheses and perspectives. Andrología 1998;30(4-5):217-24.

Vicente JS, Lavara R, Marco-Jiménez F, Viudes-de-Castro MP. Detrimental effect on availability of buserelin acetate administered in seminal doses in rabbits.Theriogenology 2011;76(6):1120-5. 
Chapter I

Viudes-de-Castro MP, Vicente JS. Effect of sperm count on the fertility and prolificity rates of meat rabbits. Anim. Reprod. Sci. 1997;46(3-4):313-9.

Viudes-de-Castro MP, Mocé E. Efecto de la linea genética del macho sobre la actividad alanina aminopeptidasa del plasma seminal de conejo. 14-15 Mayo de 2013; XV Jornadas sobre Producción Animal (AIDA), Zaragoza, España. Tomo I:pp: 428-430.

Viudes-de-Castro MP, Mocé E, Lavara R, Marco-Jiménez F, Vicente JS. Aminopeptidase activity in seminal plasma and effect of dilution rate on rabbit reproductive performance after insemination with an extender supplemented with buserelin acetate. Theriogenology 2014;81(9):1223-8.

\section{Acknowledgements}

This research was supported in part by the RTA2013-00058-00-00 from INIA, the European Social Fund and the European FEDER Funds. L. Casares-Crespo is supported by a scholarship from Instituto Valenciano de Investigaciones Agrarias (IVIA) and the

Fund. 
IV.CHAPTER II 

IV.CHAPTER ||

\section{Insemination extender supplementation with bestatin}

\section{and EDTA has no effect on rabbit reproductive}

\section{performance}

L. Casares-Crespo ${ }^{a}$, P. Fernández-Serrano ${ }^{a}$, J.S. Vicente ${ }^{b}$, E. Mocéa ${ }^{a}$ C.

Castellini $^{\mathrm{c}}$, A.M. Stabile ${ }^{\mathrm{d}}$ and M.P. Viudes-de-Castro ${ }^{\mathrm{a}}$

${ }^{a}$ Centro de Investigación y Tecnología Animal-Instituto Valenciano de Investigaciones Agrarias (CITA-IVIA), Polígono La Esperanza no 100, 12400 Segorbe, Castellón, Spain

${ }^{\mathrm{b}}$ Instituto de Ciencia y Tecnología Animal, Universidad Politécnica de Valencia, 46071 Valencia, Spain

'Department of Agrarian, Food and Environmental Sciences, Università di Perugia, 06100 Perugia, Italy

${ }^{d}$ Department of Surgery and Biomedical Sciences, School of Medicine - Human, Clinical and Forensic Anatomy- Università degli studi di Perugia, P.le Lucio Severi, 1 Sant'Andrea delle Fratte 06132, Perugia, Italy

Theriogenology. 2018;105:61-65. 



\section{ABSTRACT}

The addition of aminopeptidase inhibitors (AMIs) to rabbit semen extenders could be a solution to decrease the hormone degradation $(\mathrm{GnRH})$ by the aminopeptidases existing in the seminal plasma. Therefore, the quantity of GnRH needed to induce ovulation in doe would be comparable with the amount administered intramuscularly (i.m.). This study was conducted to evaluate the effects of two AMIs (bestatin and EDTA) on rabbit semen quality parameters, $\beta$ nerve growth factor ( $\beta$-NGF) degradation and reproductive performance after artificial insemination. Results showed that seminal quality was not affected by the incubation with AMIs; the values of motility, acrosome integrity and sperm viability were not significantly different between the AMIs and the control groups (positive i.m. and negative intravaginally without AMIs). In addition, the aminopeptidase activity of seminal plasma was inhibited in a $55.5 \%$ by the AMIs as well as $\beta$-NGF degradation. On the other hand, regarding the effect of AMIs on reproductive performance, our results showed that the presence of bestatin and EDTA did neither affect the fertility ( $85.3 \mathrm{vs.} 88.6 \%$ ), nor the prolificacy rate $(10.12$ vs. 10.51 kits per delivery), comparing AMls group to positive control group, respectively. We conclude that the addition of specific AMIs in the rabbit semen extender has no effect on reproductive performance. Therefore, due to the fact that AMIs inhibit part of the aminopeptidase activity that degrades the $\mathrm{GnRH}$ analogue and $\beta$-NGF, they could be used to develop new extenders with less hormone concentration. 



\section{INTRODUCTION}

The use of artificial insemination (Al) in rabbit farms has become a common practice in European countries, being currently used in more than $80 \%$ of the Spanish and EU rabbit farms (Quintela et al., 2009). The rabbit is considered a reflexively ovulating species in which ovulation is induced by sensory stimulation associated with mating. On the other hand, seminal plasma contains a protein, $\beta$-NGF, which is able to provoke the ovulation induction in females of other ovulating species such as camelids (Kershaw-Young et al., 2012). Although $\beta$-NGF has been identified in seminal plasma of rabbits (Casares-Crespo et al., 2016a), the genital somatosensory stimulus during coitus seems to be the main factor in the ovulation induction. Indeed, Silva et al. (2011) administered rabbit seminal plasma intramuscularly (i.m.) but it did not provoke ovulation in rabbit does. $\beta$-NGF in rabbit's seminal plasma only represents $1.5 \%$ of the total protein content of seminal plasma (results not published) and its amount is very low (1984 $\pm 277 \mathrm{pg} / \mathrm{mL}$ ) (Maranesi et al., 2015) in comparison to the llama, another reflex ovulating species, where it represents $30 \%$ of the total seminal plasma protein content (20 mg/ejaculate) (Berland et al., 2016). Nevertheless, this protein has an important role in promoting the formation and development of the testis and the differentiation, maturation, and movement of the spermatozoa (Li et al., 2010).

Therefore, when artificial insemination (AI) is used in rabbits, it is necessary to induce ovulation with $\mathrm{GnRH}$ synthetic analogues. In most rabbit farms, GnRH administration is usually done by the farmer himself, with a certain risk of misuse, and an increase in the time needed for each Al (Quintela et al., 2004). GnRH analogues administration in rabbit could be performed i.m. or intravaginally (i.v.). The addition of the $\mathrm{GnRH}$ to the seminal dose reduces the time spent by farmers in Al procedures (Dal Bosco et al., 
Chapter II

2011) and it is also a welfare-orientated method to induce ovulation in rabbits. The success of this method depends on the enzymes present in the seminal plasma (Viudes-de-Castro et al., 2014), the status of the vaginal mucosa, the extender composition (Dal Bosco et al., 2014) and the GnRH analogue used. Unfortunately, to achieve fertility results similar to those with $\mathrm{GnRH}$ intramuscular injection, the hormone concentration intra-vaginally is much higher than the amount administered intramuscularly (Viudes-de-Castro et al., 2014).

In previous works, the bioavailability of buserelin acetate when added to the seminal dose appeared to be determined by the seminal plasma aminopeptidase activity (APN) (Viudes-de-Castro et al., 2014) and the addition of a protease inhibitor cocktail to the semen extender negatively affected the prolificacy rate (Casares-Crespo et al., 2016b). Therefore, in order to reduce the amount of hormone needed to induce ovulation without affecting the litter size, new semen extenders with specific Aminopeptidase Inhibitors (AMIs) should be developed.

APN activity has been inhibited in animal sperm with different substances such as bestatin (Togo and Morisawa, 2004; Kubo et al., 2008; Yasuhara et al., 1983; Flaherty et al., 1993), Ethylenediaminetetraacetic acid (EDTA) (Nag Das et al., 1984, 1988; Farach et al., 1987; Deppe et al., 2008), or both (Huang et al., 1997; Marinho et al., 2008). This inhibition can affect different fertilization steps depending on the species considered. To our knowledge, no previous study of the effect of these inhibitors on rabbit semen and fertilization processes has been done. In addition, no previous data are available regarding the effect of AMIs on seminal $\beta$-NGF.

The aim of this study was to evaluate the effect of the inclusion of bestatin and EDTA in semen extender on aminopeptidase activity and $\beta$-NGF protection in semen. 
Moreover, the effect of these inhibitors was evaluated on in vitro rabbit semen traits (motility, acrosome status and viability) and on in vivo reproductive performance (fertility and prolificacy) after artificial insemination.

\section{MATERIALS AND METHODS}

The chemicals used in this study were purchased from Sigma-Aldrich Química S.A. (Madrid, Spain), except for busereline acetate, which was purchased from Hoechst Marion Roussel, S.A. (Madrid, Spain); SYBR-14, propidium iodide (PI) and fluorescein isothiocyanate-conjugated peanut agglutinin (FITC-PNA), were purchased from Invitrogen (Barcelona, Spain).

\section{In vitro effect of aminopeptidase inhibitors on seminal quality}

\subsection{Animals}

All animals were handled according to the principles of animal care published by Spanish Royal Decree 53/2013.

To study the effect of AMIs (bestatin and EDTA) on semen quality parameters, 12 adult bucks belonging to a paternal rabbit line (Line R, Estany et al., 1992) were used. All males were kept individually in flat deck cages under $16 \mathrm{~h}$ light/8 $\mathrm{h}$ dark conditions at the experimental farm of the Animal Technology and Research Centre (CITA-IVIA, Segorbe, Castellón, Spain) and fed ad libitum with the same commercial diet $(17.5 \%$ crude protein, $2.3 \%$ ether extract, $16.8 \%$ crude fiber, $2.600 \mathrm{kcal} \mathrm{DE} / \mathrm{Kg}$ ) and had free access to water. 
Chapter II

Seminal samples were collected using an artificial vagina over twelve weeks. Each week, two ejaculates per male/day were collected with a minimum of 30 minutes between ejaculate collections.

\subsection{Semen evaluation}

Sperm evaluation was performed to assess the initial seminal quality. Only ejaculates exhibiting a white colour and possessing motility rate higher than $70 \%$ were used in the experiment. Finally, the ejaculates were pooled. In total, twelve pools were used. Seminal quality was evaluated on aliquots of pooled semen. A $20 \mu \mathrm{L}$ aliquot was diluted $1: 50$ with $0.25 \%$ glutaraldehyde solution to calculate the concentration and rate of abnormal sperm in a Thoma chamber by phase contrast at a magnification of 400X.

The motility characteristics of sperm (percentage of total motile sperm, evaluated using a computer-assisted sperm analysis system) were determined as described by Viudes de Castro et al. (2014). Briefly, sperm samples were adjusted to $7 \times 10^{6}$ sperm/mL with TCG (Tris-Citric acid-Glucose) extender (Viudes-de-Castro and Vicente, 1997) supplemented with $2 \mathrm{~g} / \mathrm{L} \mathrm{BSA}$ and motility was assessed at 37으. A spermatozoa was defined as non-motile if the average path velocity (VAP) was $<10 \mu \mathrm{m} \mathrm{s}^{-1}$ and a spermatozoon was considered to be progressively motile when VAP was $>50 \mu \mathrm{m} \mathrm{s}^{-1}$ and the straightness index (STR) was $\geq 70 \%$.

Flow cytometric analyses to assess acrosome integrity and viability were performed using a Coulter Epics XL cytometer (Beckman Coulter, IZASA, Barcelona, Spain). The fluorophores were excited by a $15 \mathrm{~mW}$ argon ion laser operating at $488 \mathrm{~nm}$. A total of 10,000 gated events (based on the forward scatter and side scatter of the sperm population recorded in the linear mode) were collected per sample. Flow cytometric 
data were analyzed with the software Expo32ADC (Beckman Coulter Inc.). Samples were diluted to $30 \times 10^{6}$ sperm/mL with TCG extender supplemented with $2 \mathrm{~g} / \mathrm{L} \mathrm{BSA}$. All the dilutions were performed at $22 \stackrel{\circ}{ } \mathrm{C}$. The percentage of viable sperm was determined using a dual fluorescent staining with SYBR-14/PI according to Viudes-deCastro et al. (2014). Only the percentages of live sperm were considered in the results (SYBR-14-positive and PI-negative). The status of the acrosome was determined using a dual fluorescent staining with FITC-PNA/PI according to Casares-Crespo et al. (2016a). Four sperm sub-populations were detected: live sperm with intact acrosome, live sperm with damaged acrosome, dead sperm with intact acrosome and dead sperm with damaged acrosome. Percentage of normal apical ridge (NAR) was calculated as the proportion of acrosome intact sperm.

\subsection{Experimental design}

Three different extenders were tested:

-TCG (control).

-TCG supplemented with busereline acetate $(10 \mu \mathrm{g} / \mathrm{mL})$.

-TCG supplemented with busereline acetate $(10 \mu \mathrm{g} / \mathrm{mL})$, bestatin $(10 \mu \mathrm{M})$ and EDTA (20 mM).

Sperm samples were split in three equal fractions and diluted with the appropriate extender (dilution 1:20; v: v). Fractions were stored two hours at room temperature $\left(20-25^{\circ} \mathrm{C}\right)$. Then, three aliquots of each sample were taken again to measure the motility, the viability and the status of the acrosome. The remaining pooled semen was used to measure seminal plasma aminopeptidase activity (APN). 
Chapter II

\subsection{Measurement of aminopeptidase activity on seminal plasma (APN)}

Semen samples were centrifuged at $7400 \times \mathrm{g}$ for $10 \mathrm{~min}$ at $22 \mathrm{o} C$. The resulting supernatants were collected and centrifuged again (7400 $\mathrm{xg}$ for $10 \mathrm{~min})$ to remove residual spermatozoa and cell debris. The resulting pellets were discarded, whereas the supernatants were stored at $-80 \stackrel{\circ}{ } \mathrm{C}$ until use.

APN activity in seminal plasma was determined according to Viudes-de-Castro et al. (2014). Briefly, samples were incubated with the substrate (alanine- $\beta$-naphthylamide) for $30 \mathrm{~min}$ at $37^{\circ} \mathrm{C}$, after which the reaction was stopped with $0.1 \mathrm{M}$ sodium acetate buffer ( $\mathrm{pH}$ 4.2). The release of $\beta$-naphthylamide as a result of enzyme activity was determined by measuring the fluorescence intensity at $460 \mathrm{~nm}$ with excitation at 355 $\mathrm{nm}$. Fluorescence values obtained by the experimental samples were transformed into pmol of released $\beta$-naphthylamide by comparison with a standard curve previously obtained. Protein concentration of semen samples was measured using the bicinchoninic acid (BCA) method, using BSA as the standard (Smith et al., 1985). APN activity and protein concentration were measured in triplicate. The peptidase activity was expressed as pmol of $\beta$-naphthylamide released per $\mathrm{mg}$ of protein per minute. In order to calculate the percentage of APN activity inhibition, the APN activity of the control group was used as reference in each case.

\subsection{Evaluation of $\beta-N G F$ on seminal plasma}

B-NGF concentration in rabbit's seminal plasma was detected by ELISA according to the manufacturer's instructions of the Duo Set ELISA (R\&D System, Milan, Italy), on ten sperm samples. Seminal samples were split in two equal fractions and diluted with the TCG extender or TCG extender supplemented with bestatin $(10 \mu \mathrm{M})$ and EDTA $(20 \mathrm{mM})$ 
(dilution 1:20; v:v) and stored at room temperature $\left(20-25{ }^{\circ} \mathrm{C}\right)$. Then, one aliquot of each sample was taken at 4,8 and 12 hours to measure $\beta$-NGF amount.

\section{In vivo effect of aminopeptidase inhibitors on reproductive performance}

\subsection{Animals}

To study the effect of AMIs on reproductive performance, commercial crossbreed does from a commercial farm (Altura, Castellón, Spain) were inseminated using semen from 50 Line $\mathrm{R}$ adult males. In order to have the same high receptivity rate, nulliparous and multiparous non-lactating does (females with more than one delivery without suckling rabbits) received an i.m. injection of 15 and $20 \mathrm{IU}$ of eCG respectively, two days before insemination.

The trial lasted from July to December 2016. Animals were housed in flat deck cages, under a 16-h light: 8-h darkness photoperiod, fed a standard diet (17.5\% crude protein, $2.3 \%$ ether extract, $16.8 \%$ crude fibre, $2600 \mathrm{Kcal} \mathrm{DE} / \mathrm{Kg}$ ) and had free access to water.

\subsection{Semen collection and evaluation}

Two ejaculates per male were collected with a minimum of 30 minutes between ejaculate collections, on a single day using an artificial vagina. Sperm evaluation was performed to assess the initial seminal quality. Only ejaculates exhibiting a white colour and possessing more than $70 \%$ of motility rate, $85 \%$ of normal intact acrosome, and less than $15 \%$ of abnormal sperm were used for this experiment. All other ejaculates were discarded.

The remaining pooled semen was split into three aliquots and diluted 1:20, respectively with: (1) TCG extender supplemented with $10 \mu \mathrm{g}$ of buserelin acetate/mL;

(2) TCG extender supplemented with bestatin $(10 \mu \mathrm{M})$, EDTA $(20 \mathrm{mM})$ and $10 \mu \mathrm{g}$ of buserelin acetate/mL; and (3) TCG extender (non GnRH - supplemented extender). 
Chapter II

\subsection{Insemination procedure}

A total of 887 inseminations were performed along three different days. Females were inseminated with $0.5 \mathrm{~mL}$ of semen using standard curved cannulas $(24 \mathrm{~cm})$. Each female was randomly assigned to one of the three experimental groups:

- Positive control group: does inseminated with $0.5 \mathrm{~mL}$ diluted semen in TCG. At the time of insemination, females were treated intramuscularly with $1 \mu \mathrm{g}$ of buserelin acetate to induce ovulation.

- Negative control group: does inseminated with $0.5 \mathrm{~mL}$ diluted semen in TCG extender supplemented with $10 \mu \mathrm{g} / \mathrm{mL}$ of buserelin acetate.

- Aminopeptidase inhibitors group: does inseminated with $0.5 \mathrm{~mL}$ diluted semen in TCG extender supplemented with bestatin $(10 \mu \mathrm{M})$, EDTA $(20 \mathrm{mM})$ and $10 \mu \mathrm{g} / \mathrm{mL}$ of buserelin acetate.

After diluting the semen in the three experimental extenders, the insemination was initiated immediately. About two hours elapsed between the first and the last inseminated female.

Pregnancy rate at birth (number of does giving birth/number of inseminated does) and prolificacy (number of total kits born) were the reproductive performances indicators considered.

\section{Statistical analysis}

The effect of the aminopeptidase activity inhibitors on motility, viability acrosome integrity, APN activity and $\beta$-NGF quantity was analysed by ANOVA using the general linear models procedure. A chi-square test was used to test differences in pregnancy rate at birth between groups and female reproductive status. A Kruskal-Wallis test was 
performed to analyze the effect of the extender used on the total number of kits born per litter and a Mann-Whitney $U$ test was used to analyse the interaction between the physiological state of the females and the total number of kits born per litter. All analyses were performed with SPSS 20.0 software package (SPSS Inc., Chicago, Illinois, USA). Values were considered statistically different at $p<0.05$. Results are presented as least square means $(\mathrm{LSM}) \pm$ standard error of the mean $(\mathrm{SE})$.

\section{RESULTS}

\section{Effect of aminopeptidase inhibitors on seminal quality}

Seminal quality parameters after the incubation of semen samples with the experimental extenders are shown in Table 2.1. The presence of AMIs had no effect on the total motility, either on the acrosome integrity, or on the viability of the spermatozoa. On the other hand, the APN activity was inhibited in the extender containing the AMIs (10 $\mu \mathrm{M}$ bestatin and $20 \mathrm{mM}$ EDTA). The average APN activity in this group was 322.88 versus 725.58 in the control group (pmol of $\beta$-naphthylamide released per mg of protein per minute). Therefore, the APN activity in AMIs extender was $55.5 \%$ lower than in the control extender.

Table 2.1. Seminal quality after two hours' incubation at room temperature with the experimental extenders (\%; least square means \pm standard error). ( $n=35$ )

\begin{tabular}{cccc}
\hline Extenders & Total & Acrosome & Viability (\%) \\
& Motility (\%) & integrity (\%) & \\
\hline TCG & $75.00 \pm 4.47$ & $86.25 \pm 4.31$ & $64.33 \pm 5.83$ \\
TCG+GnRH analogue & $78.83 \pm 4.28$ & $86.53 \pm 4.11$ & $68.55 \pm 5.83$ \\
TCG+GnRH analogue+AMIs & $67.92 \pm 4.28$ & $84.44 \pm 4.11$ & $64.24 \pm 5.83$ \\
\hline
\end{tabular}


Chapter II

TCG: Tris-Citric acid-Glucose extender; GnRH analogue: $10 \mu \mathrm{g} / \mathrm{mL}$ busereline acetate; AMls: Aminopeptidase inhibitors (10 $\mu \mathrm{M}$ bestatin and $20 \mathrm{mM}$ EDTA).

\section{Effect of aminopeptidase inhibitors on $\beta$-NGF quantity}

The effect of the addition of AMls to rabbit semen samples is represented in Figure 2.1. The results showed that the presence of AMIs improved the availability of $\beta$-NGF in the semen up to 12 hours of storage compared to control group (2350 versus 1550 pg $\beta-N G F / m L$ seminal plasma, $p<0.05)$.

Figure 2.1. Time-dependent effect of aminopeptidase inhibitors $(10 \mu \mathrm{M}$ bestatin and $20 \mathrm{mM}$ EDTA) on seminal $\beta-N G F$ (means \pm standard error).

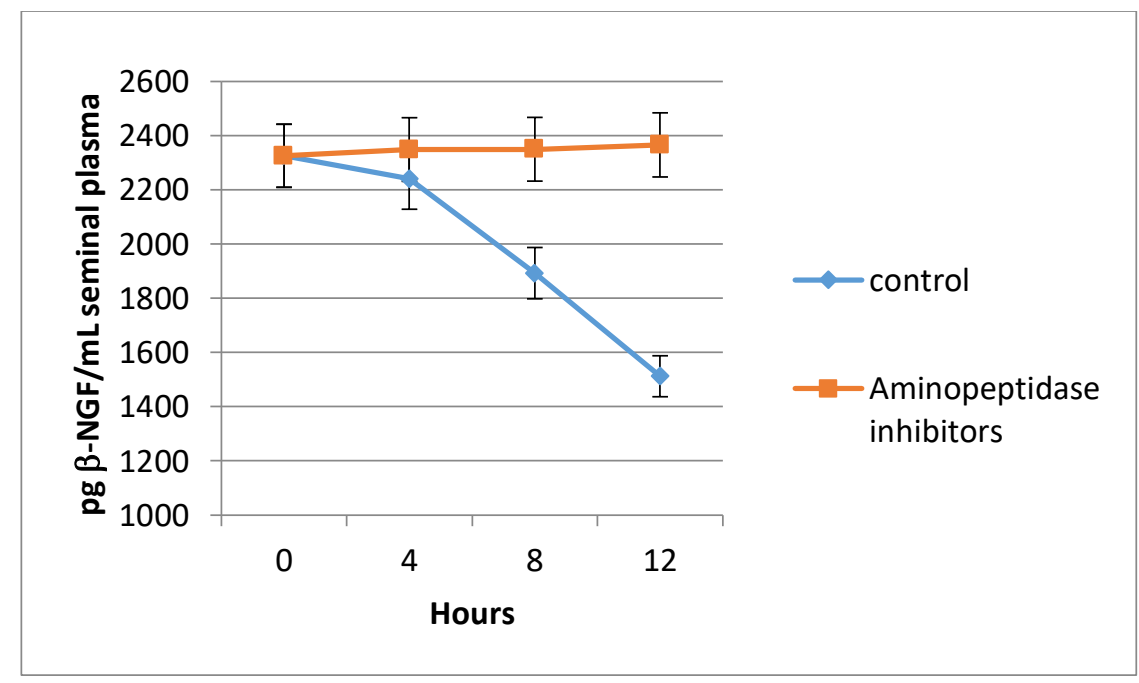

\section{Effect of aminopeptidase inhibitors on fertility and prolificacy}

Fertility rate at birth and prolificacy values are presented in Table 2.2. A total of 39 does died in the period from the insemination to kindling, 13 in the control group, 7 in the negative control and 19 in the AMIs group. Neither fertility nor prolificacy were affected by the experimental group, being both parameters similar between groups. 
Table 2.2. Reproductive performance of inseminated does induced to ovulate with buserelin acetate applied intramuscularly (Positive Control) or intravaginally with buserelin acetate supplemented extender without (Negative control) or with AMIs.

\begin{tabular}{cccc}
\hline Groups & $\begin{array}{c}\text { Inseminated } \\
\text { does }(\mathbf{N})\end{array}$ & $\begin{array}{c}\text { Pregnancy rate at } \\
\text { birth }(\%)\end{array}$ & $\begin{array}{c}\text { Total Born per } \\
\text { litter (LSM } \pm \text { SE) }\end{array}$ \\
\hline Positive Control & 263 & $88.6(233 / 263)$ & $10.51 \pm 0.19$ \\
Negative control & 286 & $86.7(248 / 286)$ & $10.21 \pm 0.19$ \\
AMls & 299 & $85.3(255 / 299)$ & $10.12 \pm 0.19$ \\
\hline
\end{tabular}

Positive Control: inseminated females treated intramuscularly with $1 \mu \mathrm{g}$ of buserelin acetate to induce ovulation. Negative control: females inseminated with $0.5 \mathrm{~mL}$ diluted semen in extender supplemented with $10 \mu \mathrm{g} / \mathrm{mL}$ of buserelin acetate. AMIs: females inseminated with $0.5 \mathrm{~mL}$ diluted semen in extender with $10 \mu \mathrm{M}$ bestatin and $20 \mathrm{mM}$ EDTA, and supplemented with $10 \mu \mathrm{g} / \mathrm{mL}$ of buserelin acetate. LSM $\pm S E$ : Least square means \pm standard error.

Regarding physiological status, nulliparous does showed significantly higher pregnancy rate at birth than the multiparous non-lactating does $(91.3 \%$ vs. $82.1 \% ; p<0.05)$. On the contrary, multiparous non-lactating does showed significant higher prolificacy than nulliparous does (10.69 \pm 0.18 vs. $9.91 \pm 0.14$ kits per delivery; $p<0.05)$.

\section{DISCUSSION}

The addition of the $\mathrm{GnRH}$ synthetic analogues to the seminal dose is a welfareorientated method to induce ovulation in rabbits but the success of this method depends on the enzymes present in the seminal plasma and unfortunately, the concentration of $\mathrm{GnRH}$ analogue to be added to the seminal dose to achieve fertility 
Chapter II

results similar to those of intramuscular administration is much higher than the amount administered intramuscularly. In a previous study we observed that the bioavailability of buserelin acetate when added to the seminal dose was determined by the activity of the existing seminal plasma aminopeptidases (Viudes-de-Castro et al., 2014) and in a latter work we showed that fertility rate was not affected by the addition of a protease inhibitor cocktail to the semen extender, but decreased the total number of kits born per litter (Casares-Crespo et al., 2016b). In the present work, the addition of specific aminopeptidase inhibitors such as bestatin and EDTA has shown no effects on fertility or prolificacy. Bestatin is a highly effective inhibitor of rabbit seminal plasma aminopeptidase activity (Casares-Crespo et al., 2015). In agreement with our results, the addition of bestatin to guinea pig sperm had no effect on membrane fusion (Flaherty et al., 1993) and the incubation of bovine sperm with EDTA did not affect the acrosome reaction (Deppe et al., 2008).

On the contrary, in non-mammal species, several authors reported that AMIs affect seminal quality and/or different fertilization steps. For instance, acrosome reaction was suppressed in the mussel in the presence of the bestatin (Togo and Morisawa, 2004), sperm binding to the vitelline envelope was inhibited in the frog (Kubo et al., 2008) and the fertilization process was inhibited in the sea urchin (Yasuhara et al., 1983). Similarly, the sperm incubation with EDTA inhibited the acrosome reaction in sea urchin sperm (Farach et al., 1987). In addition, puromycin-sensitive aminopeptidase-deficient mice are infertile, lack copulatory behavior, and have impaired spermatogenesis (Osada et al., 2001), suggesting that aminopeptidase activity is necessary for the fertilization in this species. Therefore, it seems that the effect of AMIs on semen and fertilization is species-specific. 
The present results showed that the addition of bestatin and EDTA in the rabbit semen extender has neither effect on semen quality nor on the fertilizing capacity of spermatozoa. In contrast with previous paper (Casares-Crespo et al., 2016b) where fertility rate of group intramuscularly treated with the GnRH analogue was significantly higher than intravaginal treated groups, in the present experiment, all groups showed the same pregnancy rate. The lack of fertility differences between intramuscularly and intravaginal $\mathrm{GnRH}$ administration could be addressed to the reproductive status of does used. It should be underlined that in the current paper all does were nonlactating, which is assumed to increase the fertility rate. On the other hand, previous paper showed (Casares-Crespo et al., 2016b) that the prolificacy of semen extender containing the same dilution rate $(1: 20)$ and $\mathrm{GnRH}$ amount $(5 \mu \mathrm{g} / \mathrm{Al})$ but with a wide variety of AMIs, was lower than semen extender without AMIs or control group with GnRH administered i.m. (8.2 vs. 9.3 and 9.2 total born per litter, respectively). The fecundation process damaged in our previous work by protease inhibition seems to not be affected by bestatin and EDTA, showing a similar prolificacy rate in groups with or without AMIs. In addition, the largest amounts of prostasomes in rabbit seminal plasma, which affect sperm kinetics traits and reactiveness of sperm to undergo capacitation and acrosome reaction (Castellini et al., 2013) seems responsible of a time-dependent modulation between ovulation and fertilization. Maranesi et al. (2015) hypothesized a mediator role of $\beta$-NGF on the modulation of ovulation/fertilization events. Furthermore, it is possible that a broad AMIs differently affected ovulation and fertilization processes, and the behavior of spermatozoa and their response to these inhibitors agents might alter the delicate equilibrium involved in capacitation and acrosome reaction processes. In the present study there is a huge 
Chapter II

degradation of $\beta$-NGF starting from $8 \mathrm{~h}$ until $12 \mathrm{~h}$. Considering the prolificacy results of the present work, the possible ovulation/fertilization modulator role of $\beta$-NGF is assured over this time by the presence of bestatin and EDTA in the extender, being able to protect $\beta$-NGF from enzyme degradation.

Since the bioavailability of buserelin acetate when added to the rabbit seminal dose appears to be partly determined by the activity of the seminal plasma aminopeptidases (Viudes-de-Castro et al., 2014), with bestatin and EDTA added to the semen extender, the hormone concentration could be reduced. Therefore, when using sperm extenders supplemented with the $\mathrm{GnRH}$ analogue, in order to reduce the $\mathrm{GnRH}$ concentration used, with the present results, the co-administration of EDTA and bestatin seems appropriate.

In the future, the next step would be to decrease the $\mathrm{GnRH}$ analogue concentration in semen extender with AMIs and to study its effect on fertility and prolificacy and the role of $\beta$-NGF on synchrony of the ovulation/fertilization process.

\section{REFERENCES}

Berland MA, Ulloa-Leal C, Barría M, Wright H, Dissen GA, Silva ME, Ojeda SR, Ratto MH. Seminal plasma induces ovulation in llamas in the absence of a copulatory stimulus: role of nerve growth factor as an ovulation-inducing factor. Endocrinology. 2016;157(8):3224-32.

Casares-Crespo L, Talaván AM, Viudes-de-Castro MP. Efecto de la inhibición de la actividad aminopeptidasa del plasma seminal sobre los parámetros de calidad seminal en conejo. XVI Jornadas sobre Producción Animal (AIDA), 19-20 Mayo 2015, Zaragoza, España. AIDA, Tomo II, pp 373-375. 
Casares-Crespo L, Talaván AM, Viudes-de-Castro MP. Can the genetic origin affect rabbit seminal plasma protein profile along the year? Reprod. Domest. Anim. 2016a;51(2):294-300.

Casares-Crespo L, Vicente JS, Talaván AM, Viudes-de-Castro MP. Does the inclusion of protease inhibitors in the insemination extender affect rabbit reproductive performance? Theriogenology 2016b;85(5):928-32.

Castellini C, Mattioli S, Ruggeri S, Dal Bosco A, Collodel G. The time-dependent effects of prostate granules and seminal plasma on the capacitation, acrosome reaction, and motility of rabbit sperm. Anim Reprod Sci. $2013 ; 140(1-2): 97-102$.

Dal Bosco A, Cardinali R, Brecchia G, Rebollar PG, Fatnassi M, Millan P, et al. Induction of ovulation in rabbits by adding lecirelin to the seminal dose: In vitro and in vivo effects of different excipients. Anim. Reprod. Sci. 2014;150(1-2):44-9.

Dal Bosco A, Rebollar PG, Boiti C, Zerani M, Castellini C. Ovulation induction in rabbit does: Current knowledge and perspectives. Anim. Reprod. Sci. 2011;129(3-4):10617.

Deppe M, Morales $\mathrm{P}$, Sanchez R. Effect of protease inhibitors on the acrosome reaction and sperm-zona pellucida binding in bovine sperm. Reprod. Domest. Anim. 2008;43(6):713-9.

Estany J, Camacho J, Baselga M, Blasco A. Selection response of growth rate in rabbit for meat production. Genetics, Selection, Evolution. 1992;24: 527-537.

Farach Jr H A, Mundy DI, Strittmatter WJ, Lennarz WJ. Evidence for the involvement of metalloendoproteases in the acrosome reaction in sea urchin sperm. The Journal of Biological Chemistry 1987;262(12):5483-7. 
Chapter II

Flaherty SP, Swann NJ. Proteases are not involved in the membrane fusion events of the Iysolecithin-mediated guinea pig sperm acrosome reaction. J. Cell. Sci. 1993;104:163-72.

Huang K, Takahara S, Kinouchi T, Takeyama M, Ishida T, Ueyama H, et al. Alanyl aminopeptidase from human seminal plasma: Purification, characterization, and immunohistochemical localization in the male genital tract. J. Biochem. $1997 ; 122(4): 779-87$.

Kershaw-Young CM, Druart X, Vaughan J, Maxwell WM. Beta-nerve growth factor is a major component of alpaca seminal plasma and induces ovulation in female alpacas. Reprod. Fertil. Dev. 2012;24(8):1093-7.

Kubo $\mathrm{H}$, Kotani $\mathrm{M}$, Yamamoto $\mathrm{Y}$, Hazato $\mathrm{T}$. Involvement of sperm proteases in the binding of sperm to the vitelline envelope in Xenopus laevis. Zoolog Sci.2008 Jan;25(1):80-7.

Li C, Sun Y, Yi K, Ma Y, Sun Y, Zhang W, et al. Detection of nerve growth factor (NGF) and its specific receptor (TrkA) in ejaculated bovine sperm, and the effects of NGF on sperm function. Theriogenology 2010;74(9):1615-22.

Maranesi M, Zerani M, Leonardi L, Pistilli A, Arruda-Alencar J, Stabile AM, Rende M, Castellini C, Petrucci L, Parrillo F, Moura A, Boiti C. Gene expression and localization of NGF and its cognate receptors NTRK1 and NGFR in the sex organs of male rabbits. Reproduction in Domestic Animals 2015;50(6):918-925.

Marinho CE, Almeida-Santos SM, Carneiro SM, Yamasaki SC, Silveira PF. Peptidase activities in crotalus durissus terrificus semen. Reproduction 2008;136(6):767-76.

Nag Das S K, Bhattacharyya AK. Purification and characterization of human seminal plasma aminopeptidase. The Italian Journal of Biochemistry 1988;37(3):148-64. 
Nag Das S K, Bhattacharyya A, Bhattacharyya AK. Aminopeptidase in human seminal plasma. Andrología 1984;16(5):451-7.

Osada T, Watanabe G, Kondo S, Toyoda M, Sakaki Y, Takeuchi T. Male reproductive defects caused by puromycin-sensitive aminopeptidase deficiency in mice. Mol. Endocrinol. 2001;15(6):960-71.

Quintela LA, Pena Al, Vega MD, Gullón J, Prieto MC, Barrio M, Becerra JJ, Maseda F, Herradón PG. Ovulation induction in rabbit does submitted to artificial insemination by adding buserelin to the seminal dose. Reprod. Nutr. Dev. 2004;44(1):79-88.

Quintela LA, Pena Al, Vega MD, Gullón J, Prieto C, Barrio M, Becerra JJ, Maseda F, Herradón PG. Reproductive performance of rabbit does artificially inseminated via intravaginal administration of [des-gly 10, D-Ala6]-LHRH ethylamide as ovulation inductor. Reprod. Domest. Anim. 2009;44(5):829-33.

Silva $M$, Niño A, Guerra $M$, Letelier C, Valderrama XP, Adams GP, Ratto $M H$. Is an ovulation-inducing factor (OIF) present in the seminal plasma of rabbits? Anim. Reprod. Sci. 2011;127(3-4):213-21.

Smith PK, Krohn RI, Hermanson GT, Mallia AK, Gartner FH, Provenzano MD. Measurement of proteinusingbicinchoninicacid. Anal. Biochem. 1985;150(1):76-85.

Togo T, Morisawa M. GPI-Anchored Aminopeptidase Is Involved in the Acrosome Reaction in Sperm of the Mussel Mytilus edulis. Molecular Reproduction and Development 2004;67:465-471.

Viudes-de-Castro MP, Vicente JS. Effect of sperm count on the fertility and prolificity rates of meat rabbits. Anim. Reprod. Sci. 1997;46(3-4):313-9.

Viudes-de-Castro MP, Mocé E, Lavara R, Marco-Jiménez F, Vicente JS. Aminopeptidase activity in seminal plasma and effect of dilution rate on rabbit reproductive 
Chapter II

performance after insemination with an extender supplemented with buserelin acetate. Theriogenology 2014;81(9):1223-8.

Yasuhara T, Yokosawa H, Hoshi M, Ishii SI. Sea urchin sperm aminopeptidase: comparative studies of sperm-associated and -solubilized enzymes. Biochemistry International 1983;7(5):593-598.

\section{Acknowledgements}

This research was supported in part by the RTA2013-00058-00-00 from INIA, the European Social Fund and the European FEDER Funds. L. Casares-Crespo is supported by a scholarship from Instituto Valenciano de Investigaciones Agrarias (IVIA) and the European Social Fund. P. Fernández-Serrano is supported by funds from Instituto Valenciano de Investigaciones Agrarias (IVIA) and Ministerio de Empleo y Seguridad Social

(Programa de

Garantía

Juvenil). 
V.CHAPTER III 



\section{V.CHAPTER III}

\section{Protection of GnRH analogue by chitosan-dextran sulfate}

\section{nanoparticles for intravaginal application in rabbit}

\section{artificial insemination}

L. Casares-Crespo, P. Fernández-Serrano and M.P. Viudes-de-Castro

Centro de Investigación y Tecnología Animal-Instituto Valenciano de Investigaciones Agrarias

(CITA-IVIA), Polígono La Esperanza no 100, 12400 Segorbe, Castellón, Spain 



\section{ABSTRACT}

The present study was designed to prove new rabbit insemination extenders containing aminopeptidase inhibitors (AMIs) with or without chitosan (CS)-dextran sulfate (DS) nanoparticles entrapping the GnRH analogue. In addition, different hormone concentrations were tested in these extenders, evaluating their in vivo effect on rabbit reproductive performance after artificial insemination. A total of 911 females were inseminated with semen diluted with the four experimental extenders (C4 group: $4 \mu \mathrm{g}$ buserelin/doe in control medium (Tris-citric acid-glucose supplemented with bestatin $10 \mu \mathrm{M}$ and EDTA $20 \mathrm{mM}$ ), C5 group: $5 \mu \mathrm{g}$ of buserelin/doe in control medium, Q4 group: $4 \mu \mathrm{g}$ of buserelin/doe into CS-DS nanoparticles in control medium, Q5 group: $5 \mu \mathrm{g}$ of busereline/doe into CS-DS nanoparticles in control medium). Results showed that fertility was significantly lower in C4 group compared to C5, Q5 and Q4 groups ( 0.7 versus $0.85,0.85$ and 0.82 , respectively). On the contrary, prolificacy was similar in the four experimental groups studied $(P>0.05)$. We conclude that the CS-DS nanoparticles prepared by a coacervation process as carrier for buserelin acetate allow to reduce the concentration of hormone used in extenders supplemented with bestatin and EDTA without affecting the fertility and prolificacy of rabbit females. 



\section{INTRODUCTION}

The vagina has been rediscovered as a potential route for systemic delivery of peptides and proteins (Hussain and Ahsan, 2005; Jitendra et al., 2011). The rich blood supply and the large surface area of the vaginal mucosa enable rapid absorption of low molecular weight drugs (Gupta et al., 2011; Jitendra et al., 2011). Artificial insemination with $\mathrm{GnRH}$ supplemented extenders is a welfare-orientated method to induce ovulation in rabbits. There are clear breeding advantages of intravaginal administration of $\mathrm{GnRH}$ analogue (noninvasive route, less treatment distress, labor for the farmers, and operating time), but unfortunately, to achieve fertility results similar to those with $\mathrm{GnRH}$ intramuscular injection, the intravaginally hormone concentration should be much higher than the amount administered intramuscularly (Viudes-deCastro et al., 2014), being a potential health risk for the farmers. The absorption of GnRH by vaginal mucosa is influenced by several factors. The main barrier is mucosal permeation, but another factor that limits the bioavailability of GnRH analogue is the proteolytic activity found in the seminal plasma as well as in the female vagina. Various approaches to improve protein delivery by vaginal route include: use of enzyme inhibitors, absorption enhancers, mucoadhesive polymers and/or novel carrier systems such as nanoparticles. In previous works, we have proved that rabbit's seminal plasma aminopeptidase activity affects the bioavailability of $\mathrm{GnRH}$ analogues added to the insemination extenders (Viudes-de-Castro et al., 2014). As a consequence, we have been trying to develop new extenders supplemented with protease and aminopeptidase inhibitors in order to protect the hormone from being degraded without affecting reproductive performance (Casares-Crespo et al., 2016, 2018). We have observed that extender supplementation with aminopeptidase inhibitors (AMIs) 
Chapter III

as bestatin and EDTA did not affect rabbit seminal quality nor reproductive performance (Casares-Crespo et al., 2018), but inhibited part of the seminal plasma aminopeptidase activity. Another possible approach in order to protect the hormone from enzyme degradation would be to encapsulate the GnRH analogue. Nanoparticles of biodegradable polymers have extensively been studied over last few decades in pharmaceutical research for controlled drug delivery. Recently, proteins such as lutein, insulin, rhodamine $6 \mathrm{G}$ and bovine serum albumin (BSA) have been entrapped in nanoparticles of chitosan (CS) and dextran sulfate (DS) for their delivery in oral or ocular mucosa (Chen et al., 2007; Pechenkin et al., 2011; Chaiyasan et al., 2015). CS and DS are biodegradable, biocompatible and non-toxic polymers of natural origin with high adsorption capacity, which are widely used in pharmaceutical formulations (Chen et al., 2003; Domínguez-Delgado et al., 2014). CS-DS nanoparticles containing buserelin acetate have been developed and in vitro tested (Fernández-Serrano et al., 2017). In this study, we achieved a hormone entrapment efficiency of $40-50 \%$ and showed that these nanoparticles did not affect rabbit seminal quality parameters and, in addition, significantly increased the acrosome integrity of spermatozoa. Therefore, the next step would be to reduce hormone concentration in the insemination extender to check if these systems are able to protect the hormone from seminal plasma enzyme degradation.

Hence, the current study aims to evaluate the effect of a $20 \%$ reduction of hormone concentration in extenders supplemented with AMIs and with the GnRH analogue free or entrapped in CS-DS nanoparticles on rabbit reproductive performance. 


\section{MATERIALS AND METHODS}

Busereline acetate was purchased from Hoechst Marion Roussel, S.A. (Madrid, Spain); DS was purchased from Thermofisher Acros Organics (Geel, Belgium) and SYBR-14 and propidium iodide (PI) were purchased from Invitrogen (Barcelona, Spain). All other chemicals and reagents were purchased from Sigma-Aldrich Química S.A. (Madrid, Spain).

\section{Animals}

All animals were handled according to the principles of animal care published by the Directive 2010/63/EU. The trial lasted from January to October 2017. Commercial crossbreed does from a commercial farm (Altura, Castellón, Spain), were inseminated using semen from 50 Line R adult males. Animals were housed in flat deck cages, under a 16-h light: 8 -h darkness photoperiod, fed a standard diet (17.5\% crude protein, $2.3 \%$ ether extract, $16.8 \%$ crude fibre, $2600 \mathrm{Kcal} \mathrm{DE} / \mathrm{Kg}$ ) and had free access to water.

\section{Semen collection and evaluation}

Two ejaculates per male were collected with a minimum of 30 minutes between ejaculate collections, on a single day using an artificial vagina. A subjective sperm evaluation was performed to assess the initial seminal quality. Only ejaculates exhibiting a white color and possessing more than $70 \%$ of motility rate, $85 \%$ of normal intact acrosome, and less than $15 \%$ of abnormal sperm were used in this experiment. All other ejaculates were discarded.

After the insemination procedure, the seminal quality of an aliquot of each experimental extender was evaluated. A $20 \mu \mathrm{L}$ aliquot was diluted 1:50 with $0.25 \%$ 
glutaraldehyde solution to calculate the concentration and the percentage of spermatozoa with normal apical ridge (NAR, percentage of acrosome integrity), in a Thoma chamber by phase contrast at a magnification of $400 \mathrm{X}$.

The motility characteristics of sperm (percentage of total motile sperm, evaluated using a computer-assisted sperm analysis system) were determined as described by Viudes de Castro et al. (2014). Briefly, sperm samples were adjusted to $7.5 \times 10^{6}$ sperm/mL with TCG extender supplemented with $2 \mathrm{~g} / \mathrm{L} \mathrm{BSA}$ and motility was assessed at $37^{\circ} \mathrm{C}$. A spermatozoa was defined as non-motile if the average path velocity (VAP) was $<10 \mu \mathrm{m} \mathrm{s}-1$ and a spermatozoon was considered to be progressively motile when VAP was $>50 \mu \mathrm{m} \mathrm{s}-1$ and the straightness index (STR) was $\geq 70 \%$.

Flow cytometry analyses to assess viability were performed using a Coulter Epics XL cytometer (Beckman Coulter, IZASA, Barcelona, Spain). The fluorophores were excited by a $15 \mathrm{~mW}$ argon ion laser operating at $488 \mathrm{~nm}$. A total of 10,000 gated events (based on the forward scatter and side scatter of the sperm population recorded in the linear mode) were collected per sample. Flow cytometry data were analyzed with the software Expo32ADC (Beckman Coulter Inc.). Samples were diluted to $30 \times 10^{6}$ sperm/mL with TCG extender supplemented with $2 \mathrm{~g} / \mathrm{L}$ BSA. All the dilutions were performed at $22{ }^{\circ} \mathrm{C}$. The percentage of viable sperm was determined using a dual fluorescent staining with SYBR-14/PI according to Viudes-de-Castro et al. (2014). Only the percentages of live sperm were considered in the results (SYBR-14-positive and PInegative). 


\section{Preparation of GnRH-loaded CS-DS nanoparticles}

CS and DS were dissolved (0.05\%) in the Control medium, which consisted in Tris-citric acid-glucose (TCG), supplemented with bestatin $10 \mu \mathrm{M}$ and EDTA $20 \mathrm{mM}$ (CasaresCrespo et al., 2018). Incorporation of buserelin acetate into nanoparticles was achieved by dissolving the hormone in DS solution in order to obtain the desired final GnRH concentration in the diluted semen $(8$ and $10 \mu \mathrm{g} / \mathrm{mL}$ for Q4 and Q5 extenders, respectively). Nanoparticles were spontaneously formed on incorporation of CS solution into DS solution (4:1) through magnetic stirring ( $600 \mathrm{rpm})$ during 30 minutes at room temperature.

\section{Semen preparation}

The seminal pools were first diluted 1:4 (vol:vol) with Control medium and then were split into four equal fractions, which were diluted 1:5 with one of the four experimental extenders, respectively, in order to obtain the desired final GnRH concentration in the diluted semen:

- C5 fraction: diluted with control medium supplemented with busereline acetate to obtain a final concentration of $10 \mu \mathrm{g} / \mathrm{mL}$ busereline acetate.

- C4 fraction: diluted with control medium supplemented with busereline acetate to obtain a final concentration of $8 \mu \mathrm{g} / \mathrm{mL}$ busereline acetate.

- Q5 fraction: diluted with Q5 extender to obtain a final concentration of $10 \mu \mathrm{g} / \mathrm{mL}$ of busereline acetate-loaded into CS-DS nanoparticles.

- Q4 fraction: diluted with Q4 extender to obtain a final concentration of $8 \mu \mathrm{g} / \mathrm{mL}$ of busereline acetate-loaded into CS-DS nanoparticles. 


\section{Insemination procedure}

In order to achieve the same high receptivity rate, nulliparous and multiparous nonlactating does (females with more than one delivery without suckling rabbits) received an intramuscular injection of 15 and 20 IU of eCG respectively, two days before insemination. To induce ovulation, the $\mathrm{GnRH}$ analogue buserelin acetate was used. A total of 911 inseminations were performed in three different days. Females were inseminated with $0.5 \mathrm{~mL}$ of diluted semen using standard curved cannulas $(24 \mathrm{~cm})$. Each female was randomly assigned to one of the four experimental extender groups: C4 group: $4 \mu \mathrm{g}$ buserelin/doe in control medium.

C5 group: $5 \mu \mathrm{g}$ of buserelin/doe in control medium.

Q4 group: $4 \mu \mathrm{g}$ of buserelin/doe into CS-DS nanoparticles in control medium.

Q5 group: $5 \mu \mathrm{g}$ of busereline/doe into CS-DS nanoparticles in control medium.

Pregnancy rate at birth (number of does giving birth/number of inseminated does) and prolificacy (number of total and alive kits born) were the reproductive performances considered.

\section{Statistical analysis}

The effect of AMIs and CS-DS nanoparticles on total motility, acrosome integrity and viability was analysed by ANOVA using the general linear model procedure. A probit link with binomial error distribution was used to analyze the fertility rate at birth, including as fixed effects the extender group and the reproductive status of the females (nulliparous and multiparous) and their interactions. For total number of kits born per litter, an ANOVA was performed, including as fixed effects the extender group 
and physiological state and their interaction. For the number of live born kits per litter, a covariance analysis was used, including the total number of kits born per litter as covariable. All analyses were performed with SPSS 16.0 software package (SPSS Inc., Chicago, IL, USA). Values were considered statistically different at $\mathrm{P}<0.05$. Results are presented as least square means $(\mathrm{LSM}) \pm$ standard error of the mean $(\mathrm{SE})$.

\section{RESULTS}

\section{Seminal quality after insemination with experimental extenders}

Seminal quality parameters of samples from the experimental extenders are shown in Table 3.1. The presence of AMIs and CS-DS nanoparticles had no effect on the total motility, either on the acrosome integrity, or on the viability of the spermatozoa.

Table 3.1. Seminal quality after insemination procedure with the experimental extenders (\%; Least square means \pm standard error) $(n=3)$.

\begin{tabular}{cccc}
\hline Extenders & Total Motility (\%) & Acrosome integrity (\%) & Viability (\%) \\
\hline C4 & $68.5 \pm 10.6$ & $89.5 \pm 6.3$ & $76.5 \pm 2.7$ \\
C5 & $63.0 \pm 10.6$ & $80.9 \pm 6.3$ & $73.3 \pm 2.7$ \\
Q4 & $59.0 \pm 10.6$ & $83.9 \pm 6.3$ & $73.1 \pm 2.7$ \\
Q5 & $68.5 \pm 10.6$ & $87.7 \pm 6.3$ & $69.5 \pm 2.7$ \\
\hline
\end{tabular}

C4: $4 \mu \mathrm{g}$ busereline/doe in control medium (Tris-citric acid-glucose supplemented with bestatin $10 \mu \mathrm{M}$ and EDTA $20 \mathrm{mM}$ ); C5: $5 \mu \mathrm{g}$ of busereline/doe in control medium; Q4: 4 $\mu g$ of busereline/doe into chitosan-dextran sulfate (CS-DS) nanoparticles in control medium; Q5: 5 $\mu \mathrm{g}$ of busereline/doe into CS-DS nanoparticles in control medium. 


\section{Reproductive performance of experimental extenders}

Fertility rate at birth and prolificacy values are presented in Table 3.2. An interaction was found between extender group and reproductive status on fertility rate. Fertility was significantly lower in the C4 group and without differences between nanoparticles groups Q4 and Q5 and control group C5. Regarding physiological status, nulliparous does showed significantly higher fertility than multiparous non-lactating does (Table 3.2). The results of the interaction indicated that nulliparous does from Q5 group showed significantly higher fertility than multiparous non-lactating does, while in the other groups, no significant difference was observed between females with different reproductive status.

No interactions were found between extender group and reproductive status on the total number of kits born per litter and number of alive kits born per litter. Prolificacy was similar in all experimental groups. The physiological status significantly affected the prolificacy. Multiparous non-lactating does showed significantly higher prolificacy of total number of kits born per litter than nulliparous does (Table 3.2).

Table 3.2. Reproductive performance of inseminated does.

\begin{tabular}{|c|c|c|c|c|}
\hline Group & $\mathbf{N}$ & Fertility at birth & TB & AB \\
\hline C4 & 294 & $0.70 \pm 0.03^{\mathbf{a}}$ & $10.69 \pm 0.20$ & $10.27 \pm 0.12$ \\
\hline C5 & 343 & $0.85 \pm 0.02^{\mathbf{b}}$ & $10.68 \pm 0.19$ & $10.16 \pm 0.11$ \\
\hline Q4 & 112 & $0.85 \pm 0.04^{\mathbf{b}}$ & $11.12 \pm 0.33$ & $10.23 \pm 0.20$ \\
\hline Q5 & 162 & $0.82 \pm 0.03^{\mathbf{b}}$ & $11.22 \pm 0.29$ & $9.94 \pm 0.18$ \\
\hline Reproductive Status & $\mathbf{N}$ & Fertility at birth & TB & AB \\
\hline MNL & 496 & $0.77 \pm 0.03^{\mathbf{a}}$ & $11.53 \pm 0.21^{\mathbf{a}}$ & $10.22 \pm 0.13$ \\
\hline N & 415 & $0.84 \pm 0.02^{\mathbf{b}}$ & $10.31 \pm 0.16^{\mathbf{b}}$ & $10.07 \pm 0.10$ \\
\hline
\end{tabular}




\begin{tabular}{|c|c|c|c|c|}
\hline \multicolumn{4}{|c|}{ Group*Reproductive status } & \\
\hline C4*MNL & 173 & $0.66 \pm 0.04^{\mathrm{a}}$ & $11.21 \pm 0.27$ & $10.36 \pm 0.16$ \\
\hline $\mathrm{C} 4 * \mathrm{~N}$ & 121 & $0.74 \pm 0.04^{\mathrm{ac}}$ & $10.17 \pm 0.30$ & $10.19 \pm 0.18$ \\
\hline $\mathrm{C} 5^{*} \mathrm{MNL}$ & 244 & $0.88 \pm 0.02^{\mathrm{bd}}$ & $11.14 \pm 0.20$ & $10.17 \pm 0.12$ \\
\hline $\mathrm{C} 5 * \mathrm{~N}$ & 99 & $0.81 \pm 0.04^{\mathrm{bce}}$ & $10.21 \pm 0.32$ & $10.15 \pm 0.19$ \\
\hline $\mathrm{Q} 4^{*} \mathrm{MNL}$ & 32 & $0.84 \pm 0.06^{\mathrm{bcdf}}$ & $11.59 \pm 0.55$ & $10.33 \pm 0.33$ \\
\hline $\mathrm{Q} 4 * \mathrm{~N}$ & 80 & $0.86 \pm 0.04^{\mathrm{bg}}$ & $10.64 \pm 0.35$ & $10.12 \pm 0.21$ \\
\hline $\mathrm{Q} 5^{*} \mathrm{MNL}$ & 47 & $0.66 \pm 0.07^{\mathrm{aef}}$ & $12.19 \pm 0.52$ & $10.04 \pm 0.31$ \\
\hline $\mathrm{Q} 5 * \mathrm{~N}$ & 115 & $0.92 \pm 0.03^{\mathrm{dg}}$ & $10.24 \pm 0.28$ & $9.84 \pm 0.17$ \\
\hline Total & 911 & $0.81 \pm 0.02$ & $10.92 \pm 0.13$ & $10.15 \pm 0.08$ \\
\hline
\end{tabular}

TB: total number of kits born per litter; $A B$ : number of alive kits born per litter; $C 4: 4 \mu \mathrm{g}$ busereline/doe in control medium (Tris-citric acid-glucose supplemented with bestatin $10 \mu \mathrm{M}$ and EDTA $20 \mathrm{mM}$ ); C5: $5 \mu \mathrm{g}$ of busereline/doe in control medium; Q4: $4 \mu \mathrm{g}$ of busereline /doe into chitosan-dextran sulfate (CS-DS) nanoparticles in control medium; Q5: $5 \mu \mathrm{g}$ of busereline /doe into CS-DS nanoparticles in control medium; MNL: females with more than one delivery without suckling rabbits; N: nulliparous does; Values within a column with different superscripts in the same column differ significantly at $\mathrm{P}<0.05$.

\section{DISCUSSION}

In rabbit artificial insemination, the administration of $\mathrm{GnRH}$ analogues in the seminal dose presents clear advantages versus intramuscular administration. However, due to degradation by aminopeptidases and the low absorption in the vagina mucosa, there is a decrease in the analogues' bioavailability and large doses are required for ovulation induction following vaginal administration. According to a previous work (CasaresCrespo et al., 2018), the employment of bestatin and EDTA in the rabbit insemination 
extenders inhibited part of the seminal aminopeptidase activity without affecting reproductive performance. On the other hand, we have developed CS-DS nanoparticles to entrap the $\mathrm{GnRH}$ analogue and a previous in vitro characterization showed that these nanoparticles did not affect rabbit seminal quality (FernándezSerrano et al., 2017).

Therefore, to increase the bioavailability of $\mathrm{GnRH}$ when intravaginally route is used, in the present study a double approach was used to protect the $\mathrm{GnRH}$ analogue against enzymatic degradation, the use of aminopeptidases inhibitors as bestatin and EDTA or/and the use of polymers as chitosan and dextran sulfate to encapsulate the GnRH analogue. Our hypothesis was that these strategies were able to protect the $\mathrm{GnRH}$ analogue and in consequence it would be possible to reduce the quantity of hormone used in the extender to induce ovulation. According to our results, when the buserelin acetate was non encapsulated, although the extenders were supplemented with bestatin and EDTA, the utilization of $4 \mu \mathrm{g}$ hormone/doe significantly reduced fertility rate compared to group with $5 \mu \mathrm{g}$ hormone/doe. This fact shows that even though part of the enzymatic activity of seminal plasma is inhibited, the bioavailability of GnRH is not enough to allow a $20 \%$ reduction in the concentration of hormone in the extender without compromising fertility. It is possible that we are working with a limiting hormone concentration ( $5 \mu \mathrm{g} / \mathrm{doe}$ ) and even a small hormone reduction could affect fertility. In this sense, there is only another work in which a GnRH analogue concentration lower than $5 \mu \mathrm{g} / \mathrm{doe}$ has been used in rabbit ovulation induction, and the results were the same as ours, with fertility rate significantly lower and similar prolificacy rate ( $2.5 \mu \mathrm{g} /$ doe GnRH-Lecirelinum in seminal dose) (Ondruška et al., 2008). 
On the other hand, when buserelin acetate was encapsulated in CS-DS nanoparticles, no differences in fertility and prolificacy were observed between $4 \mu \mathrm{g}$ hormone/doe or $5 \mu \mathrm{g}$ hormone/doe, showing similar values than C5 group. Thus, with the use of nanoparticles, the $\mathrm{GnRH}$ analogue seems to be protected against degradation and a $20 \%$ hormone reduction does not affect fertility. In resemblance with our results, Trapani et al. (2010) employed CS based nanoparticles in oral administration of a small peptide (glutathione), and they achieved to protect the drug from the enzymatic gastric degradation and induce permeabilization of the intestinal epithelia. In addition, Han et al. (1995), in an in vitro study in rabbit, observed that the permeability of the vaginal membrane to $\mathrm{GnRH}$ increased twice when EDTA was used, suggesting that enzyme inhibition effect of EDTA resulted in substantial enhancement of vaginal absorption. Therefore, the enzyme inhibitor role of bestatin and EDTA besides the absorption enhancement effect of EDTA and the protection role of chitosan and dextran sulfate nanoparticles and their mucoadhesive function, all together, could explain the fertility rate improvement of Q4 group compared to C4 group.

In conclusion, the CS-DS nanoparticles prepared by coacervation process as carrier for buserelin acetate overcome some of the limitations associated with the vaginal application of the hormone in rabbit artificial insemination and allow to reduce the concentration of hormone used in an extender supplemented with bestatin and EDTA without affecting the fertility and prolificacy of rabbit females. Therefore, nanoencapsulation seems to be a promising system to protect the $\mathrm{GnRH}$ analogue in order to decrease the hormone concentration in rabbit artificial insemination extenders. 
Chapter III

\section{REFERENCES}

Casares-Crespo L, Vicente JS, Talaván AM, Viudes-de-Castro MP. Does the inclusion of protease inhibitors in the insemination extender affect rabbit reproductive performance? Theriogenology 2016;85(5):928-32.

Casares-Crespo L, Fernández-Serrano P, Vicente JS, Mocé E, Castellini C, Stabile AM, Viudes-de-Castro MP. Insemination extender supplementation with bestatin and EDTA has no effect on rabbit reproductive performance. Theriogenology 2018;105:61-65.

Chaiyasan W, Srinivas SP, Tiyaboonchai W. Crosslinked chitosan-dextran sulfate nanoparticle for improved topical ocular drug delivery. Mol. Vis. 2015;21:1224-34.

Chen Y, Mohanraj VJ, Parkin, JE. Chitosan-dextran sulfate nanoparticles for delivery of an anti-angiogenesis peptide.Letters in Peptide Science 2003;10(5-6):621-629.

Chen Y, Mohanraj VJ, Wang F, Benson HA. Designing chitosan-dextran sulfate nanoparticles using charge ratios. AAPS Pharm. Sci. Tech. 2007;8(4):131-139.

Domínguez-Delgado CL, Rodríguez-Cruz IM, Fuentes-Prado E, Escobar-Chávez JJ, VidalRomero G, García-González L, Puente-Lee RI. Drug carrier systems using chitosan for non-parenteral routes. Pharmacology and Therapeutics. InTech 2014;273-275.

Fernández-Serrano P, Casares-Crespo L, Viudes-de-Castro MP. Chitosan-dextran sulfate nanoparticles for $\mathrm{GnRH}$ release in rabbit insemination extenders. Reprod. Domest. Anim. 2017;52(4):72-74.

Gupta S, Gabrani R, Ali J, Dang S. Exploring novel approaches to vaginal drug delivery.Recent Patents on Drug Delivery \& Formulation 2011;5(2):82-94. 
Han K, Park JS, Chung YB, Jeong NJ, Park HB, Robinson JR. Development of luteinizing hormone releasing hormone (LHRH) delivery systems for vaginal mucosal route. Archives of Pharmacal Research 1995;18(5):325-331.

Hussain A, Ahsan F. The vagina as a route for systemic drug delivery.Journal of Controlled Release 2005;103(2):301-313.

Jitendra, Sharma PK, Bansal S, Banik A. Noninvasive routes of proteins and peptides drug delivery. Indian Journal of Pharmaceutical Sciences 2011;73(4):367-375.

Ondruška L, Parkányi V, Rafay J, Chlebec I. Effect of LHRH analogue included in seminal dose on kindling rate and prolificacy of rabbits artificially inseminated. In Proc: $9^{\text {th }}$ World Rabbit Science Congress, 10-13 June, Verona, Italy 2008;s.122:423-6.

Pechenkin MA, Balabushevich NG, Zorov IN, Staroseltseva LK, Mikhalchik EV, Izumrudov VA, Larionova N. Design in vitro and in vivo characterization of chitosandextran sulfate microparticles for oral delivery of insulin. J. Bioequiv. Availab. 2011;3:244-50.

Trapani A, Lopedota A, Franco M, Cioffi N, leva E, García-Fuentes M, Alonso MJ. A comparative study of chitosan and chitosan/cyclodextrin nanoparticles as potential carriers for the oral delivery of small peptides. European Journal of Pharmaceutics and Biopharmaceutics 2010;75(1):26-32 .

Viudes-de-Castro MP, Mocé E, Lavara R, Marco-Jiménez F, Vicente JS. Aminopeptidase activity in seminal plasma and effect of dilution rate on rabbit reproductive performance after insemination with an extender supplemented with buserelin acetate. Theriogenology 2014;81(9):1223-8. 
Chapter III

\section{Acknowledgements}

This research was supported in part by the RTA2013-00058-00-00 from INIA, the European Social Fund and the European FEDER Funds. L. Casares-Crespo is supported by a scholarship from Instituto Valenciano de Investigaciones Agrarias (IVIA) and the European Social Fund. P. Fernández-Serrano is supported by Spanish funds from IVIA and Ministerio de Empleo y Seguridad Social (Youth Guarantee Program). 
VI.CHAPTER IV 



\title{
VI.CHAPTER IV
}

\section{Can the genetic origin affect rabbit seminal plasma}

\section{protein profile along the year?}

\author{
L. Casares-Crespo ${ }^{a}$, A.M. Talaván ${ }^{b}$ and M.P. Viudes-de-Castro ${ }^{a}$ \\ ${ }^{\text {a }}$ Centro de Investigación y Tecnología Animal-Instituto Valenciano de Investigaciones Agrarias \\ (CITA-IVIA), Polígono La Esperanza no 100, 12400 Segorbe, Castellón, Spain

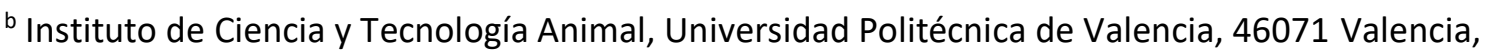 \\ Spain
}

Reproduction in Domestic Animals. 2016;51(2):294-300. 



\section{ABSTRACT}

The study was designed to evaluate the influence of genetic origin on rabbit seminal plasma protein profile variation along the year. Seminal plasma of rabbits from line A (maternal line) and R (paternal line) collected during a natural year was subjected to polyacrylamide gel electrophoresis (SDS-PAGE). The electrophoretic profile of rabbit seminal plasma resulted in multiple protein bands of different intensity ranging from 9 to $240 \mathrm{kDa}$. Results showed that seven protein bands were significantly different between genetic lines and among these three protein bands were significantly different between seasons. The differentially expressed proteins were identified by MALDI TOF/TOF or LC-MS/MS analysis and were the following ones: FAM115E-like (220, 113 and $59 \mathrm{kDa}$ ), ectonucleoside triphosphate diphosphohydrolase 3 isoform X2 (72 kDa), annexin A5 (32 kDa), lipocalin allergen Ory c 4 precursor (19 kDa), and hemoglobin subunit zeta-like (13 kDa) between genetic lines and FAM115E-like (113 $\mathrm{kDa})$, hemoglobin subunit zeta-like $(13 \mathrm{kDa})$ and $\beta$-Nerve growth factor (12 kDa) between seasons. These results indicate that proteins from rabbit seminal plasma are under both seasonal and genetic control. Furthermore, the differential presence of these proteins could be one of the causes explaining the differences observed in fertility and seminal parameters between these two lines in earlier studies. 



\section{INTRODUCTION}

Seminal plasma is a promising source for the study of potential reproductive biomarkers, because it is a complex mixture of secretions from testis, epididymis and male accessory sex glands (González-Cadavid et al., 2014). Species of mammals differ regarding the presence and size of accessory sexual glands, which obviously lead to variations in their relative contribution to semen composition and volume, particularly regarding seminal plasma (Rodríguez-Martínez et al., 2011). Seminal fluid is very complex and plays an important role in the fertilizing ability of sperm (La Falci et al., 2002). The protein composition of mammalian seminal plasma varies among species, and has important effects on sperm function (Mortarino et al., 1998). These proteins participate in various events related to sperm function such as epididymal sperm maturation, sperm capacitation, sperm membrane stabilization and even the interaction with the oviduct and oocyte (Topfer-Petersen et al., 1998; Gwathmey et al., 2006). The diversity in the seminal plasma protein composition of different species of mammals may explain the variation in reproductive capacity and function (Druart et al., 2013). In rabbits, seminal plasma has a positive effect in maintaining sperm motility and viability during in vitro storage (Castellini et al., 2000). This effect has been associated with the antioxidant properties of seminal plasma (Arruda-Alencar et al., 2012).

In some species, seminal plasma proteins related to fertility (Killian et al., 1993; Brandon et al., 1999; Ashrafzadeh et al., 2013), cold-shock damage sperm membrane resistance (Barrios et al., 2000; Pérez-Pé et al., 2001), sperm tolerance to freezing (Goularte et al., 2014), freezability (Jobim et al., 2011) and semen quality (Cardozo et al., 2006; De Souza et al., 2007; Arruda-Alencar et al., 2012; Nandre et al., 2013; Kiso et 
al., 2013) have been identified. In addition, differences in seminal plasma protein composition among seasons have been examined in several species (goat: La Falci et al., 2002; Teixeira et al., 2009; ram: Cardozo et al., 2006; Domínguez et al., 2008; buffalo: Nandre et al., 2013; Sharma et al., 2014). In an earlier study, Viudes-de-Castro et al. (2004) studied the protein composition of rabbit $A$ and $R$ lines seminal plasma and observed two line-specific protein bands (line A $41 \mathrm{kDa}$; line R $13 \mathrm{kDa}$ ). On the contrary, in a recent study with the same rabbit lines, Safaa et al. (2008) found no differences in the protein profile. Both studies were conducted in different seasons, the first one in winter and the second in spring, which could indicate the possible existence of seasonal variations in the seminal plasma protein composition in this species.

On the other hand, rabbit semen characteristics vary from one season to another (Marai et al., 2002). Several studies have found variations of rabbit sperm parameters depending on the environmental conditions (Marai et al., 2002; Nizza et al., 2003; Pascual et al., 2004; Roca et al., 2005; Schneidgenová et al., 2011; Ain-Baziz et al., 2012; Sabés-Alsina et al., 2015; Theau-Clément et al., 2015). For instance, TheauClément et al. (2015) observed that except for $\mathrm{pH}$, all rabbit semen characteristics were influenced by the season, being sperm production higher in autumn. In addition, Schneidgenová et al. (2011) showed the seasonal effect on the fertility traits of rabbit ejaculates and concluded that is necessary to evaluate the semen quality of bucks throughout the year. The aim of the present study was to evaluate the effect of genetic line and season on rabbit seminal plasma protein profile along the year. 


\section{MATERIALS AND METHODS}

Unless stated otherwise, all chemicals in this study were purchased from Sigma-Aldrich Química S.A (Madrid, Spain).

\section{Animals}

All animals were handled according to the principles of animal care published by Spanish Royal Decree 53/2013.

To study the seasonal variation of seminal plasma proteins, a total of 24 adult bucks, 12 belonging to a paternal rabbit line (Line $\mathrm{R}$ ) and 12 from a maternal rabbit line (Line A) were used. All bucks were of proven fertility and subjected to a weekly pattern of ejaculate collection. Males were kept individually in flat deck cages under $16 \mathrm{~h}$ light/8 $h$ dark conditions at the experimental farm of the Animal Technology and Research Centre (CITA-IVIA, Segorbe, Castellón, Spain) and fed ad libitum with the same commercial diet $(17.5 \%$ crude protein, $2.3 \%$ ether extract, $16.8 \%$ crude fiber, 2.600 $\mathrm{kcal} \mathrm{DE} / \mathrm{Kg}$ ) and had free access to water.

\section{Semen collection}

One ejaculate per male was collected each week using an artificial vagina. Sperm evaluation was performed to assess the initial seminal quality. Only ejaculates exhibiting a white colour and possessing more than 70 of motility rate, $85 \%$ of normal intact acrosome, and less than $15 \%$ of abnormal sperm were used in this experiment. All ejaculates from the same line were pooled ( 12 pools from Line $R$ and 12 pools from Line A, 3 pools for each season and line). The sperm recovery was performed from January to December 2014. Table 4.1 reports the minimum, maximum and mean temperatures recorded during the whole period of study. 
Table 4.1. Temperatures registered during the trial (year 2014) in Segorbe (mean \pm SD).

\begin{tabular}{cccc}
\hline Season & \multicolumn{3}{c}{ Temperature (ㄷ) } \\
\hline & Minimum & Maximum & Average \\
\cline { 2 - 4 } Winter (21st December-20th March) & $4.36 \pm 0.11$ & $16.87 \pm 1.58$ & $10.69 \pm 0.63$ \\
Spring (21st March-20th June) & $10.77 \pm 2.76$ & $25.15 \pm 2.56$ & $18.14 \pm 2.80$ \\
Summer (21st June-20th September) & $16.56 \pm 1.28$ & $29.62 \pm 0.97$ & $22.98 \pm 0.87$ \\
Autumn (21st September-20th & & & \\
December) & $7.47 \pm 4.04$ & $20.02 \pm 5.74$ & $13.43 \pm 4.89$ \\
\hline
\end{tabular}

\section{Preparation of seminal plasma samples}

Semen samples were centrifuged at $7400 \times \mathrm{g}$ for $10 \mathrm{~min}$ at $22 \stackrel{\circ}{ } \mathrm{C}$. The resulting supernatants were collected and centrifuged again (7400 $\mathrm{xg}$ for $10 \mathrm{~min}$ ) to remove residual spermatozoa and cell debris. The resulting pellets were discarded, whereas the supernatants were collected, supplemented with a protease inhibitor cocktail (P2714, Sigma) diluted 1:100 and stored at -80 ㅇ C until use.

After thawing, total protein concentration was quantified by the bicinchoninic acid method (BCA) using BSA as standard protein (Smith et al., 1985). To perform electrophoresis, samples were diluted in saline at a concentration of $5 \mu \mathrm{g} / \mu \mathrm{L}$. After this, three pools of each season were pooled resulting in one sample per line and season (8 samples in total). Later, samples were mixed with $2 x$ Laemmli buffer and boiled at 95ㄷ for 5 minutes. 


\section{Polyacrylamide gel electrophoresis (SDS-PAGE)}

Protein samples were electrophoresed using two polyacrylamide concentrations, 13 and $22 \%$. A $5 \%$ stacking gel was used in all runs. The total loaded quantity of protein in each well was $25 \mu \mathrm{g}$ in $10 \mu \mathrm{L}$. Gels were run in a PROTEAN ${ }^{\circledR}$ II XL Cell (Bio-Rad Laboratories, Hercules, CA, USA) with constant voltage of $180 \mathrm{~V}$ for $3 \mathrm{~h}$ and $250 \mathrm{~V}$ for $5 \mathrm{~h}$. The molecular weight was estimated using Precision Plus Protein ${ }^{\text {TM }}$ Dual Xtra Standards (Bio-Rad). At the end of the electrophoresis, the gels were fixed with a fixation solution (50\% water, $40 \%$ absolute ethanol, $20 \%$ acetic acid) during 20 minutes, stained with Coomassie Colloidal Blue (Bio-Rad) overnight and then destained with three changes of destaining solution (water) at room temperature.

The 1D gel images were processed for analysis with Quantity One 1-D software (BioRad) to determine the molecular weight and relative quantity of each protein band.

\section{Protein identification}

The eight protein bands that resulted significantly different between genetic lines and seasons were carefully excised and places into micro tubes. The proteomic analysis was carried out in the SCSIE University of Valencia Proteomics Unit, a member of the PRB2-ISCIII ProteoRed Proteomics Platform.

\section{MALDI TOF/TOF analysis}

\subsection{Sample preparation}

Samples were digested with sequencing grade trypsin (Promega) as described elsewhere (Shevchenko et al., 1996). The digestion was stopped with Trifluoroacetic 
Chapter IV

acid ( $1 \%$ final concentration); the digested peptides were concentrated to $15 \mu \mathrm{L}$. A BSA plug was analysed in the same way to control the digestion process.

\subsection{MALDI TOF/TOF analysis}

Previously, the plate and the acquisition methods were calibrated with $0.5 \mu \mathrm{L}$ the $\mathrm{CM} 5$ calibration mixture (AB Sciex), in 13 positions. The resulting mixtures were analyzed in a 5800 MALDI TOF/TOF (AB Sciex) in positive reflectron mode (3000 shots every position). Five of the most intense precursors (according to the threshold criteria: minimum signal-to-noise: 10, minimum cluster area: 500, maximum precursor gap: 200 ppm, maximum fraction gap: 4, were selected for every position for the MSMS analysis. And, MS/MS data was acquired using the default $1 \mathrm{kV} \mathrm{MS} / \mathrm{MS}$ method.

\subsection{Protein identification}

The MS-MSMS information was sent to MASCOT search engine v 4.0 (Matrix-Science) via the Protein Pilot (AB Sciex). Database search was performed on NCBI database. Searches were done with tryptic specificity allowing one missed cleavage and a tolerance on the mass measurement of $100 \mathrm{ppm}$ in MS mode and 0.8 Da in MSMS mode. Carbamidomethylation of Cys was used as a fixed modification and oxidation of Met and deamidation of Asn and GIn as variable modifications.

\section{LC MS/MS analysis}

Two protein bands (220 and $19 \mathrm{kDa}$ ) could not be identified by MALDI TOF/TOF analysis because they were a mixture of different proteins. Therefore, a liquid chromatography and tandem mass spectrometry (LC MS/MS) analysis was performed. 


\subsection{Sample preparation}

Samples were digested as described previously. The digestion was stopped with Trifluoroacetic acid (1\% final concentration); the digested peptides were concentrated to $20 \mu \mathrm{L}$ (band $220 \mathrm{kDa}$ ) or $10 \mu \mathrm{L}$ (band $19 \mathrm{kDa}$ ).

\subsection{LC MS/MS analysis}

$5 \mu \mathrm{L}$ of every sample (except the main bands) were loaded onto a trap column (nanoLC Column, $3 \mu \mathrm{m}$ C18-CL, $350 \mu \mathrm{m}$ diameter $\times 0.5 \mathrm{~mm}$; Eksigen Technologies) and desalted with $0.1 \%$ TFA at $3 \mu \mathrm{L} / \mathrm{min}$ during $5 \mathrm{~min}$. The peptides were then loaded onto an analytical column (LC Column, $3 \mu \mathrm{m}$ particles size $\mathrm{C} 18-\mathrm{CL}, 75 \mu \mathrm{m}$ diameter $\times 12 \mathrm{~cm}$ long, Nikkyo) equilibrated in 5\% acetonitrile (ACN) 0.1\% FA (formic acid). Elution was carried out with a linear gradient of 5 to $45 \%$ solvent B in A for 45 min. (A: $0.1 \%$ FA; B: ACN, $0.1 \% \mathrm{FA}$ ) at a flow rate of $300 \mathrm{~nL} / \mathrm{min}$. Peptides were analysed in a mass spectrometer nano ESI qQTOF (5600 TripleTOF, AB Sciex). The triple TOF was operated in information-dependent acquisition mode, in which a 0.25-s TOF MS scan from 350$1250 \mathrm{~m} / \mathrm{z}$ was performed, followed by 0.05 -s product ion scans from $100-1500 \mathrm{~m} / \mathrm{z}$ on the 50 most intense $2-5$ charged ions.

\subsection{Protein identification}

ProteinPilot search engine v 4.5. (AB Sciex) default parameters were used to generate peak list directly from 5600 Triple TOF wiff files. The Paragon algorithm of Protein Pilot was used to search $\mathrm{NCBI}$ protein database with the following parameters: trypsin specificity, iodoacetamide cys-alkylation, no taxonomy restriction except for some particular spots, and the search effort set to rapid. To avoid using the same spectral evidence in more than one protein, the identified proteins are grouped based on MS/MS spectra by the Protein-Pilot Progroup algorithm. Thus, proteins sharing MS/MS 
Chapter IV

spectra are grouped, regardless of the peptide sequence assigned. The protein within each group that can explain more spectral data with confidence is shown as the primary protein of the group. Only the proteins of the group for which there is individual evidence (unique peptides with enough confidence) are also listed, usually toward the end of the protein list.

\section{Statistical analysis}

Data were statistically evaluated with Statgraphics ${ }^{\circledR}$ Plus 5.1 library procedures (Statistical Graphics Corp., Rockville, MO, USA). To analyze the differences in relative quantity of each protein band based on the genetic line and season, a two-way analysis of variance (ANOVA) was used. Means were separated using the Fishers Least Significant Difference (LSD) test at a fixed 5\% error level and the results are presented as the least square mean values $(\mathrm{LSM}) \pm$ the standard error $(\mathrm{SE})$.

\section{RESULTS}

Gel images are shown in Figure 4.1 and 4.2. The electrophoretic profile of rabbit seminal plasma resulted in multiple bands of different intensity ranging from 9 to 240 $\mathrm{kDa}$. A total of 30 protein bands were identified, 21 and 13 in the 13 and $22 \%$ gels, respectively, with four bands in common between both gels. In the $13 \%$ gel, molecular weights ranged from 241 to $25 \mathrm{kDa}$ and in the $22 \%$ gel, from 37 to $9.7 \mathrm{kDa}$. 
Figure 4.1. 5-13\% SDS-PAGE of rabbit seminal plasma proteins. Lane 1 and 6 are molecular weight markers ( 250 to $25 \mathrm{kDa}$ ). Lane 2 and 3 are $A$ and $\mathrm{R}$ line in winter, respectively. Lane 4 and 5 are $A$ and $R$ line in spring. Lane 7 and 8 are $A$ and $R$ line in summer. And lane 9 and 10 are $A$ and $R$ line in autumn.

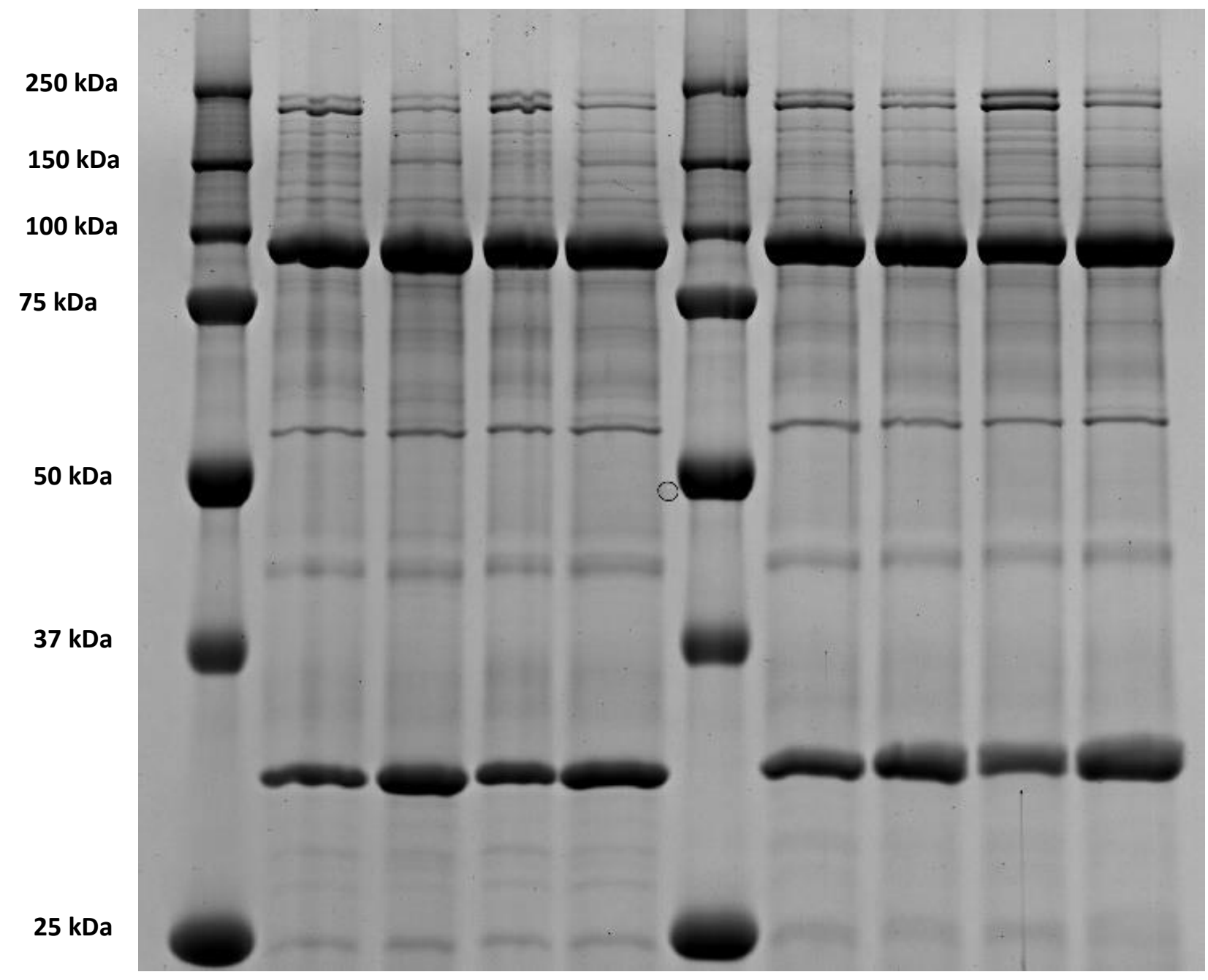


Figure 4.2. 5-22\% SDS-PAGE of rabbit seminal plasma proteins. Lane 1 and 6 are molecular weight markers ( 37 to $10 \mathrm{kDa}$ ). Lane 2 and 3 are $A$ and $R$ line in winter, respectively. Lane 4 and 5 are $A$ and $R$ line in spring. Lane 7 and 8 are $A$ and $R$ line in summer. And lane 9 and 10 are $A$ and $R$ line in autumn.

$37 \mathrm{kDa}$

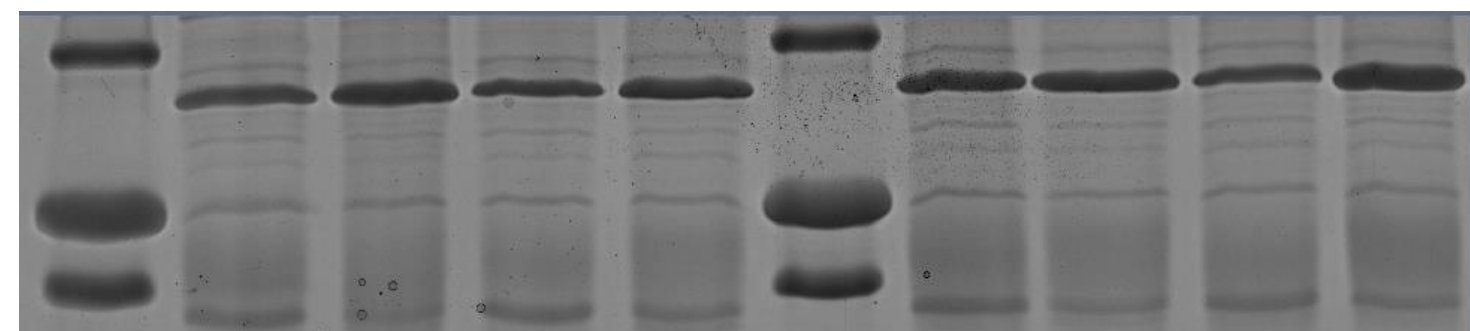

$15 \mathrm{kDa}$

$10 \mathrm{kDa}$

Significantly different protein bands between genetic lines and seasons are shown in Table 4.2. Seven proteins bands were significantly different between genetic lines $(p<0.05)$.The relative quantity of FAM115E-like $(220,113$ and $59 \mathrm{kDa})$, ectonucleoside triphosphate diphosphohydrolase 3 isoform X2 (72 kDa), annexin A5 (32 kDa), lipocalin allergen Ory c 4 precursor (19 kDa), and hemoglobin subunit zeta-like (13 kDa) was significantly different between lines A and R. Of those seven protein bands, A line exhibited significantly higher values in four of them. Regarding the effect of season on the protein profile, three protein bands were significantly different between seasons $(p<0.05)$. FAM115E-like $(113 \mathrm{kDa})$ and $\beta$-Nerve growth factor (NGF, $12 \mathrm{kDa})$ protein bands were significantly decreased in winter, whereas hemoglobin subunit zeta-like protein band ( $13 \mathrm{kDa})$ was significantly increased in winter and spring. 
Table 4.2. Relative quantity of significantly different protein bands from rabbit seminal plasma according to genetic line and season $(\mathrm{LSM} \pm \mathrm{SE})$.

\begin{tabular}{|c|c|c|c|c|c|c|c|c|c|}
\hline \multirow{2}{*}{$\begin{array}{c}\text { Molecular } \\
\text { weight } \\
\text { (kDa) }\end{array}$} & \multirow{2}{*}{ Protein } & \multicolumn{3}{|c|}{ Line } & \multicolumn{5}{|c|}{ Season } \\
\hline & & A & $\mathbf{R}$ & SE & Winter & Spring & Summe & Autumn & SE \\
\hline 220 & FAM115E-like & $6.35^{a}$ & $1.66^{\mathrm{b}}$ & \pm 0.58 & 3.46 & 3.60 & 3.65 & 5.29 & \pm 0.83 \\
\hline 113 & FAM115E-like & $0.58^{a}$ & $0.64^{b}$ & \pm 0.01 & $0.53^{a}$ & $0.61^{b}$ & $0.60^{\mathrm{b}}$ & $0.70^{c}$ & \pm 0.01 \\
\hline 72 & $\begin{array}{l}\text { Ectonucleoside } \\
\text { triphosphate } \\
\text { diphosphohydrol } \\
\text { ase } 3 \text { isoform X2 }\end{array}$ & $0.55^{\mathrm{a}}$ & $0.33^{b}$ & \pm 0.05 & 0.44 & 0.60 & 0.38 & 0.34 & \pm 0.07 \\
\hline 59 & FAM115E-like & $0.02^{\mathrm{a}}$ & $0.19^{b}$ & \pm 0.03 & 0.15 & 0.11 & 0.09 & 0.08 & \pm 0.04 \\
\hline 32 & Annexin A5 & $21.09^{a}$ & $28.71^{b}$ & \pm 0.80 & 24.89 & 23.86 & 26.70 & 23.90 & \pm 1.13 \\
\hline 19 & $\begin{array}{l}\text { Lipocalin allergen } \\
\text { Ory c } 4 \text { precursor }\end{array}$ & $7.72^{\mathrm{a}}$ & $2.76^{b}$ & \pm 0.96 & 6.34 & 6.40 & 5.16 & 3.03 & \pm 1.36 \\
\hline 13 & $\begin{array}{c}\text { Hemoglobin } \\
\text { subunit zeta-like }\end{array}$ & $16.89^{a}$ & $14.99^{b}$ & \pm 0.22 & $17.09^{b}$ & $16.89^{b}$ & $14.64^{a}$ & $15.13^{a}$ & \pm 0.31 \\
\hline 12 & $\begin{array}{l}\text { B-Nerve growth } \\
\text { factor (NGF) }\end{array}$ & 6.35 & 6.97 & \pm 0.60 & $2.5^{\mathrm{a}}$ & $8.51^{b}$ & $7.81^{\mathrm{b}}$ & $7.81^{\mathrm{b}}$ & \pm 0.84 \\
\hline
\end{tabular}

Values with different superscript in the same row and factor (line or season) differ significantly at $5 \%$ level $(p<0.05)$.

\section{DISCUSSION}

Seminal plasma composition is characterized by a high abundance of proteins which play important roles in sperm survival and are involved in various events related with the sperm physiology, the gamete interaction and fusion and even pregnancy establishment (Okabe et al., 1993, Topfer-Petersen et al., 1998, Gwathmey et al., 2006, Rodríguez-Martínez et al., 2011). In the present work, our results show the existence of differences in the relative quantity of many seminal plasma proteins belonging to male genetic $A$ line against $R$ line along the year. 
Chapter IV

On the contrary to the previous findings of Viudes-de-Castro et al. (2004), we did not found the presence of line-specific protein bands. This difference may be due to the different protein analysis and the higher resolution protein electrophoresis used in the present study.

FAM115E protein is also known as experimental autoimmune prostatitis antigen 2 (http://www.uniprot.org/uniprot/D3ZRI3). In this work, this protein was present in three different sizes $(220,113$ and $59 \mathrm{kDa})$, what suggests that rabbit seminal plasma FAM115E protein has several subunits. The biological role of FAM115E in rabbit semen remains unknown and we have not been able to find any reference of the presence of this protein in the seminal plasma of other species.

The function of ectonucleoside triphosphate diphosphohydrolase 3 isoform X2 and its relationship with semen function remains unknown to date. In a previous study by Taha et al. (2006) in rabbit seminal plasma, they found an association between the decreasing content of a $70 \mathrm{kDa}$ peptide band and the increased percentage of altered acrosome. The protein band of ectonucleoside triphosphate diphosphohydrolase 3 isoform $X 2(72 \mathrm{kDa})$ found in the present study could be the same protein that these authors found. Therefore, the greater quantity of $72 \mathrm{kDa}$ protein in $\mathrm{A}$ line versus $\mathrm{R}$ line could explain the better acrosome integrity of spermatozoa from A line found in earlier studies (Vicente et al., 2000; Safaa et al., 2008).

The lipocalins are a diverse family of extracellular transport proteins that show high binding affinity for small hydrophobic ligands and specific cell surface receptors (Gerena et al., 1998). Lipocalins have also been found in boar seminal plasma (González-Cadavid et al., 2014). In this work, A line had significantly more quantity of lipocalin allergen Ory c 4 precursor than $\mathrm{R}$ line. If this protein is related to fertility like 
in other species such as the bull (Gerena et al., 1998), this could explain the better fertility of A line compared to R line found in previous works (Vicente et al., 2000; Mocé et al., 2003; Vicente et al., 2012).

Zeta globin-like protein in rabbit seminal plasma has been correlated with the percentage of cells with both membrane and acrosome damage (Arruda-Alencar et al., 2012). This finding contradicts the results found in this work because $A$ line contains more hemoglobin subunit zeta-like protein but does not have more percentage of sperm with acrosome damage (Vicente et al., 2000; Safaa et al., 2008).

Annexin $5(32 \mathrm{kDa})$ was found to be one of the most abundant seminal plasma proteins in rabbit, which agrees with previous works (Taha et al., 2011; Arruda-Alencar et al., 2012). This protein is an anticoagulant that appears to have a beneficial effect in maintaining rabbit sperm viability, given its positive correlation with several semen parameters such as sperm vigor, concentration and percentage of morphologically normal sperm (Arruda-Alencar et al., 2012). In this work, $R$ line has more quantity of Annexin 5 protein but this finding does not match with better sperm vigor or higher sperm concentration of $R$ line (Lavara et al., 2013) compared with A line (Sabés-Alsina et al., 2015).

Season is one of the main causes of sperm quality traits variation in rabbits (Marai et al., 2002; Nizza et al., 2003; Pascual et al., 2004; Roca et al., 2005; Schneidgenová et al., 2011; Ain-Baziz et al., 2012; Sabés-Alsina et al., 2015; Theau-Clément et al., 2015). This variation could be due to differences in seminal plasma or sperm membrane composition (Lavara et al., 2013). In the present work, FAM115E-like (113 kDa) and NGF (12 kDa) were significantly decreased in winter, whereas hemoglobin subunit zeta-like (13 kDa) was significantly increased in winter and spring. The NGF protein, 
neurotropin primarily involved in the development and maintenance of the nervous system, has also been recognized to influence the reproductive system. Regarding the male, NGF and its two receptors were reported to be expressed in the testis, prostate gland and seminal vesicle of rabbit, suggesting a possible role of this factor in the testicular development and spermatogenesis (Maranesi et al., 2015). Furthermore, there are some evidences of the involvement of this protein in sperm motility since it has been observed that exogenous NGF stimulate the motility in a time and dosedependent manner (Jin et al., 2010; Shi et al., 2012). The wild rabbit is a seasonal breeder with the peak of reproductive activity occurring in the spring and early summer. With domestic rabbits, genetic selection and environmental control have resulted in sexual activity throughout the year, with periods of reduced fertility. An autumn fertility drop is also often noticed as a result of high summer temperatures. Results from this work showed that the production of NGF in rabbit seminal plasma during winter decreases four times compared to the other seasons. This may be related to the natural reluctance of rabbits to breed in the early winter. This result is in agreement with Schneidgenová et al. (2011) findings which showed less sperm motility and concentration during winter season. Besides, this also accords with Zhang et al. (2015) findings in wild ground squirrels, which showed that the production of NGF in testes was decreased during the non-breeding season and increased in the breeding season.

In conclusion, the results of the present work indicate that the protein composition of rabbit seminal plasma varies both in terms of the male genetic line and the season, although more protein variation was found between genetic lines than between seasons. However, further studies are needed to elucidate the exact role of these 
seminal plasma proteins and identify those related to changes in fertility in this species.

\section{REFERENCES}

Ain-Baziz H, Boulbina I, Ilès I, Belabbas R, Zenia S, Temim S. Influence of environmental temperature and relative humidity on semen characteristics in male rabbit (Oryctolagus cuniculus) of local Algerian population. In Proc: $10^{\text {th }}$ World Rabbit Congress, September 3 - 6, Sharm El- Sheikh -Egypt, 2012:347-350.

Arruda-Alencar JM, Viana-Neto AM, Souza CEA, Martins JAM, Moreno FB, Moreira ACO, Guerreiro MEF, Moura AA. Major proteins of the seminal plasma of New Zealand White rabbits and association with semen criteria. In Proc: $10^{\text {th }}$ World Rabbit Congress, September 3 - 6, Sharm El- Sheikh -Egypt, 2012:395-399.

Ashrafzadeh A, Nathan S, Karsani SA. Comparative analysis of Mafriwal (Bos taurus $x$ Bos indicus) and Kedah Kelantan (Bos indicus) sperm proteome identifies sperm proteins potentially responsible for higher fertility in a tropical climate. Int. J. Mol. Sci. 2013;14:15860-15877.

Barrios B, Pérez-Pé R, Gallego M, Tato A, Osada J, Muiño-Blanco T, Cebrián-Pérez JA. Seminal plasma proteins revert the cold-shock damage on ram sperm membrane. Biol. Reprod. 2000;63:1531-1537.

Brandon $\mathrm{Cl}$, Heusner $\mathrm{GL}$, Caudle $\mathrm{AB}$, Fayrer-Hosken RA.Two-dimensional polyacrylamide gel electrophoresis of equine seminal plasma proteins and their correlation with fertility.Theriogenology 1999;52:863-873. 
Cardozo JA, Fernández-Juan M, Forcada F, Abecia A, Muiño-Blanco T, Cebrián-Pérez JA. Monthly variations in ovine seminal plasma proteins analyzed by two-dimensional polyacrylamide gel electrophoresis. Theriogenology 2006;66:841-850.

Castellini C, Lattaioli P, Moroni M, Minelli A. Effect of seminal plasma on the characteristics and fertility of rabbit spermatozoa. Anim. Reprod. Sci. 2000;63:275282.

De Souza FF, Barreto CS, Lopes MD. Characteristics of seminal plasma proteins and their correlation with canine semen analysis. Theriogenology 2007;68:100-106.

Domínguez MP, Falcinelli A, Hozbor F, Sanchez E, Cesari A, Alberio RH. Seasonal variations in the composition of ram seminal plasma and its effect on frozenthawed ram sperm. Theriogenology 2008;69:564-573.

Druart X, Rickard JP, Mactier S, Kohnke PL, Kershaw-Young CM, Bathgate R, Gibb Z, Crossett B, Tsikis G, Labas V, Harichaux G, Grupen CG, de Graaf SP. Proteomic characterization and cross species comparison of mammalian seminal plasma. Journal of Proteomics 2013;91:13-22.

Gerena RL, Irikura D, Urade Y, Eguchi N, Chapman DA, Killian GJ. Identification of a fertility-associated protein in bull seminal plasma as lipocalin-type prostaglandin D synthase. Biol. Reprod. 1998;58:826-833.

González-Cadavid V, Martins JA, Moreno FB, Andrade TS, Santos AC, Monteiro-Moreira AC, Moreira RA, Moura AA. Seminal plasma proteins of adult boars and correlations with sperm parameters. Theriogenology2014;82:697-707.

Goularte KL, Gastal GD, Schiavon RS, Goncalves AO, Schneider JR, Corcini CD, Lucia T. Association between the presence of protein bands in ram seminal plasma and sperm tolerance to freezing. Anim. Reprod. Sci. 2014;146:165-169. 
Gwathmey TM, Ignotz GG, Mueller JL, Manjunath P, Suarez SS. Bovine seminal plasma proteins PDC-109, BSP-A3, and BSP-30-kDa share functional roles in storing sperm in the oviduct. Biol. Reprod. 2006;75:501-507.

Jin W, Tanaka A, Watanabe G, Matsuda H, Taya K. Effect of NGF on the motility and acrosome reaction of golden hamster spermatozoa in vitro. Journal of Reproduction and Development 2010;56:437-443.

Jobim MI, Trein C, Zirkler H, Gregory RM, Sieme H, Mattos RC. Two-dimensional polyacrylamide gel electrophoresis of equine seminal plasma proteins and their relation with semen freezability. Theriogenology 2011;76:765-771.

Killian GJ, Chapman DA, Rogowski LA. Fertility-associated proteins in Holstein bull seminal plasma. Biol. Reprod. 1993;49:1202-1207.

Kiso WK, Selvaraj V, Nagashima J, Asano A, Brown JL, Schmitt DL, Leszyk J, Travis AJ, Pukazhenthi BS. Lactotransferrin in Asian elephant (Elephas maximus) seminal plasma correlates with semen quality. PLoS One 2013;8:e71033.

La Falci VS, Tortorella H, Rodrigues JL, Brandelli A. Seasonal variation of goat seminal plasma proteins. Theriogenology 2002;57:1035-1048.

Lavara R, David I, Mocé E, Baselga M., Vicente JS. Environmental and male variation factors of freezability in rabbit semen. Theriogenology 2013;79:582-589.

Marai IFM, Habeeb AAM, Gad AE. Rabbits' productive, reproductive and physiological performance traits as affected by heat stress: a review. Livestock Production Science 2002;78(2):71-90.

Maranesi M, Zerani M, Leonardi L, Pistilli A, Arruda-Alencar J, Stabile AM, Rende M, Castellini C, Petrucci L, Parillo F, Moura A, Boiti C. Gene Expression and Localization 
of NGF and Its Cognate Receptors NTRK1 and NGFR in the Sex Organs of Male Rabbits. Reprod. Domest. Anim. 2015;50(6):918-25.

Mocé E, Vicente JS, Lavara R. Effect of freezing-thawing protocols on the performance of semen from three rabbit lines after artificial insemination. Theriogenology 2003;60:115-123.

Mortarino M, Tedeschi G, Negri A, Ceciliani F, Gottardi L, Maffeo G, Ronchi S. Twodimensional polyacrylamide gel electrophoresis map of bull seminal plasma proteins. Electrophoresis 1998;19:797-801.

Nandre RM, Fatima Sh, Bhupal G, Derashri HJ, Joshi CG.Assessment of variations in Indian Bubalus bubalis seminal plasma proteins during winter and summer seasons. Iranian Journal of Veterinary Research 2013;14(1):1-8.

Nizza A, Di Meo C, Taranto S. Effect of Collection Rhythms and Season on Rabbit Semen Production. Reprod. Domest. Anim. 2003;38(6):436-439.

Okabe M, Kishi Y, Ying X, Kohama Y, Mimura T, Li SS. Characterization of capacitation inhibitory protein from rabbit seminal plasma: Homology with human annexins. Biol. Pharm. Bull 1993;16(5):453-6.

Pascual JJ, García C, Martínez E, Mocé E, Vicente JS. Rearing management of rabbit males selected by high growth rate: the effect of diet and season on semen characteristics. Reprod. Nutr. Dev. 2004;44:49-63.

Pérez-Pé R, Cebrián-Pérez JA, Muiño-Blanco T. Semen plasma proteins prevent coldshock membrane damage to ram spermatozoa. Theriogenology 2001;56:425-434.

Roca J, Martínez S, Orengo J, Parrilla I, Vázquez JM, Martínez, EA. Influence of constant long days on ejaculate parameters of rabbits reared under natural environment conditions of Mediterranean area. Livestock Production Science 2005;94:169-177. 
Rodríguez-Martínez H, Kvist U, Ernerudh J, Sanz L, Calvete JJ. Seminal plasma proteins: what role do they play? Am. J. Reprod. Immunol. 2011;66(1):11-22.

Sabés-Alsina M, Planell N, Torres-Mejia E, Taberner E, Maya-Soriano MJ, Tusell L, Ramon J, Dalmau A, Piles M, Lopez-Bejar M. Daily exposure to summer circadian cycles affects spermatogenesis, but not fertility in an in vivo rabbit model. Theriogenology 2015;83:246-252.

Safaa HM, Vicente JS, Lavara R, Viudes-de-Castro MP. Semen evaluation of two selected lines of rabbit bucks. World Rabbit Science 2008;16:141-148.

Shi Cui-Ge, Lin K, Xu Xiang-Bo, Zhang Shu-Cheng, Wang N, Fan M. Evidence for the involvement of NGF in human sperm motility. J. Biomedical Science and Engineering 2012;5:534-541.

Schneidgenová M, Vašíček J, Čupka P, Chrenek P. Is it necessary to control seasonal quality of the rabbit ejaculate? Slovak J. Anim. Sci. 2011;44(2):48-51.

Sharma L, Pandey V, Nigam R, Singh P, Saxena A, Swain DK. Seasonal variations in seminal plasma proteins of buffalo. Reprod. Domest. Anim. 2014;49:387-391.

Shevchenko A, Jensen ON, Podtelejnikov AV, Sagliocco F, Wilm M, Vorm O, Mortensen $\mathrm{P}$, Boucherie $\mathrm{H}$, Mann $\mathrm{M}$. Linking genome and proteome by mass spectrometry: large-scale identification of yeast proteins from two dimensional gels. Proceedings of the National Academy of Sciences of the United States of America 1996;93:14440-14445.

Smith PK, Krohn RI, Hermanson GT, Mallia AK, Gartner FH, Provenzano MD, Fujimoto EK, Goeke NM, Olson BJ, Klenk DC. Measurement of protein using bicinchoninic acid. Anal. Biochem. 1985;150:76-85. 
Taha TA, Shaaban WF, EL-Mahdy AR, EL-Nouty FD, Salem MH. Reproductive toxicological effects of gossypol on male rabbits: Semen characteristics and hormonal levels. Anim. Sci. 2006;82:259-269.

Taha TA, Shaaban WF, EL-Nouty FD, Salem MH. Molecular approach of gossypolinduced reproductive toxicity in male rabbits. Electrophoretic pattern of seminal plasma proteins. Egyptian J. Anim. Prod. 2011;48(2):217-230.

Teixeira AVC, Eloy AMX, Furtado JR, Pinheiro RR, Pontes MS. 1D mapping of seminal plasma proteins in Anglo-Nubian goats. Anim. Reprod. 2009;6(4):516-525.

Theau-Clément M, Bolet G, Sanchez A, Saleil G, Brun JM. Some factors that influence semen characteristics in rabbits. Anim. Reprod. Sci. 2015;157:33-38.

Topfer-Petersen E, Romero A, Varela PF, Ekhlasi-Hundrieser M, Dostalova Z, Sanz L, Calvete JJ. Spermadhesins: a new protein family. Facts, hypotheses and perspectives. Andrología 1998;30:217-224.

Vicente JS, Viudes-de-Castro MP, Lavara R, Lavara F. Effect of male line on prolificacy from does inseminated with low sperm doses. In Proc: $7^{\text {th }}$ World Rabbit Congress, 47 July 2000, Valencia, Spain. 2000;Vol A:273-277.

Vicente JS, Llobat L, Viudes-de-Castro MP, Lavara R, Baselga M, Marco-Jiménez F. Gestational losses in a rabbit line selected for growth rate. Theriogenology $2012 ; 77: 81-88$

Viudes-de-Castro MP, Marco-Jiménez F, Vicente JS, Navarro E, Lavara R, Mocé E. Sperm kinetic parameters and differences in seminal plasma composition among two rabbit lines. In Proc: $8^{\text {th }}$ Annual Conference of ESDAR. Reprod. Dom Anim. 2004;39(4), pp. 266 (Abstract P13). WARSAW Agricultural University, Polonia. 
Zhang H, Wang Y, Zhang J, Wang L, Li Q, Sheng X, Han Y, Yuan Z, Weng Q. Testicular expression of NGF, TrkA and p75 during seasonal spermatogenesis of the wild ground squirrel (Citellus dauricus Brandt). Eur. J. Histochem. 2015;59(3):2522.

\section{Acknowledgements}

This research was supported in part by the RTA2013-00058-00-00 from INIA, the European Social Fund and the European FEDER Funds. L. Casares-Crespo is supported by a scholarship from Instituto Valenciano de Investigaciones Agrarias (IVIA) and the

Fund. 



\section{VII.CHAPTER V}





\section{VII.CHAPTER V}

\section{Rabbit seminal plasma proteome: the importance of the}

\section{genetic origin}

L. Casares-Crespo ${ }^{a}$, P. Fernández-Serrano ${ }^{a}$, J.S. Vicente ${ }^{b}$, F. Marco-Jiménez ${ }^{b}$ and M.P. Viudes-de-Castro ${ }^{a}$

${ }^{a}$ Centro de Investigación y Tecnología Animal-Instituto Valenciano de Investigaciones Agrarias (CITA-IVIA), Polígono La Esperanza no 100, 12400 Segorbe, Castellón, Spain

b Instituto de Ciencia y Tecnología Animal, Universidad Politécnica de Valencia, 46071 Valencia, Spain

Animal Reproduction Science. 2018;189-30-42. 



\section{ABSTRACT}

The present study was conducted to characterise rabbit seminal plasma proteins (SP proteins) focusing on the influence of the genetic origin and seasonality. In addition, $\beta$ NGF protein quantity in SP was determined. Semen samples were recovered from January to December 2014 using 6 males belonging to genotype A and six from genotype R. For each genotype, one pooled sample at the beginning, middle and end of each season was selected to develop the experiment. A total of 24 pools ( 3 for each season and genetic line) were analysed. SP proteins of the two experimental groups were recovered and subjected to in-solution digestion nano LC-MS/MS and bioinformatics analysis. The resulting library included 402 identified proteins validated with $\geq 95 \%$ Confidence (unused Score $\geq 1.3$ ). These data are available via ProteomeXchange with identifier PXD006308. Only 6 proteins were specifically implicated in reproductive processes according to Gene Ontology annotation. Twentythree proteins were differentially expressed between genotypes, 11 over-expressed in genotype $A$ and 12 in genotype R. Regarding the effect of season on rabbit SP proteome, results showed that there is no clear pattern of protein variation throughout the year. Similar $\beta$-NGF relative quantity was observed between seasons and genotypes. In conclusion, this study generates the largest library of SP proteins reported to date in rabbits and provide evidence that genotype is related to a specific abundance of SP proteins. 



\section{INTRODUCTION}

The control of rabbit reproduction has experienced great changes in the last decade, mainly as a consequence of the development of new techniques such as commercially applicable artificial insemination (Al) (Safaa et al., 2008). The use of Al in intensive meat rabbit production is currently a common practice (Piles et al., 2013), like in the vast majority of livestock (Hansen, 2014), and it utilisation has contributed to improve the knowledge of rabbit spermatozoa and bucks' management (Boiti et al., 2005; Castellini et al., 2008; Lavara et al., 2005; Pascual et al., 2016; Safaa et al., 2008; TheauClément et al., 2015, 2016; Viudes-de-Castro et al., 2014). Rabbit ejaculates present some peculiarities that should be taken into account, for instance, they present occasionally gel plug or gelatinous mass and contain several vesicles that have been related to modulate different sperm functions such as motility, capacitation and acrosome reaction (Castellini et al., 2006, 2012, 2013; Collodel et al., 2012). In addition, rabbit belongs to the few species in which ovulation is induced by copulation (Fisher et al., 2012), like cats, camelids, koala, voles and sumatran rhinos (McGraw et al., 2015). In these species, a specific protein named $\beta$-NGF has been studied in seminal plasma because of its potential role in inducing ovulation in camelids (Adams and Ratto, 2013; Berland et al., 2016; Druart et al., 2013; Kershaw-Young et al., 2012; Li et al., 2010; Silva et al., 2011). Nevertheless, in rabbits, the intramuscular administration of seminal plasma did not provoke ovulation (Silva et al., 2011), but plays a role in promoting the formation and development of the testis and the differentiation, maturation, and movement of the spermatozoa (Li et al., 2010). Many factors influence the production and quality of rabbit semen such as the genetic origin (growth lines have worse seminal qualities and fertility rates than maternal 
Chapter V

lines) (Mocé et al., 2003; Vicente et al., 2000), the season (Marai et al., 2002; Pascual et al., 2004; Schneidgenová et al., 2011; Theau-Clément et al., 2015), the photoperiod (Ain-Baziz et al., 2012; Roca et al., 2005; Sabés-Alsina et al., 2015) and the collection frequency (Nizza et al., 2003). The production of fertile doses is determined by several components: i) male libido and characteristics of the ejaculate which form part of the criterion for ejaculate rejection; ii) volume and sperm concentration of the ejaculate (determining the amount of doses that can be obtained); and iii) the quality of sperm (determining the minimum sperm dosage required to ensure fertilization) (Piles et al., 2013). Subjective estimation of motility and evaluation of sperm morphology are the two laboratory assays most widely used for the rabbit semen evaluation in insemination centers (Lavara et al., 2005). However, the ability of these seminal characteristics to predict reproductive performance is very low (Piles et al., 2013). In line with the greater number of livestock species, the prediction of ejaculates of high fertility or good cryopreservation remains unresolved. However, while most of these previous studies have been focused on the sperm cell, little attention has been paid to the seminal plasma in rabbit. To date, a limited number of studies have performed an analysis of rabbit seminal plasma proteins (Arruda-Alencar et al., 2012; Casares-Crespo et al., 2016a; Davis and Davis, 1983; de Lamirande et al., 1983; Lavon, 1972; Minelli et al., 2001; Okabe et al., 1993; Thomas et al., 1986; Viudes-de-Castro et al., 2004) in comparison to the main commercially relevant domestic mammalian species (Rodríguez-Martínez et al., 2011; Druart et al., 2013; Bromfield, 2016).

Seminal plasma contributes to the safe environment for sperm maturation, sperm viability and fertilization in mammals (Muiño-Blanco et al., 2008; Rodríguez-Martínez et al., 2011; Manjunath et al., 2007; Bromfield, 2016). Moreover, seminal plasma is a 
promising source for the study of potential reproductive biomarkers, because it is a complex mixture of secretions from testis, epididymis and male accessory sex glands (González-Cadavid et al., 2014). Sperm maturation is acquired during the transit of the spermatozoa through the epididymis, where its plasma membrane undergoes intense changes in protein composition and in localization of their components (Dacheux et al. 2003). The protein composition of mammalian seminal plasma varies among species, and has important effects on sperm function (Rodríguez-Martínez et al., 2011). Even though seminal plasma contains hundreds of proteins, their functions are not completely understood. In rabbits, seminal plasma has a positive effect in maintaining sperm motility and viability during in vitro storage (Castellini et al., 2000).

Against this background, the present study was conducted to characterise rabbit seminal plasma proteins through nano LC-MS/MS analysis, focusing on the influence of the genetic origin and seasonality. In addition, $\beta$-NGF protein quantification was done.

\section{MATERIALS AND METHODS}

Unless stated otherwise, all chemicals in this study were purchased from Sigma-Aldrich Química S.A (Madrid, Spain). All the experimental procedures used in this study were performed in accordance with Directive 2010/63/EU EEC for animal experiments.

\section{Localization and animals}

The experiment was carried out with 24 males from two Spanish commercial rabbit genetic lines (genotypes A and R) from January to December 2014. All bucks were of proven fertility and subjected to a weekly pattern of ejaculate collection. Line $A$ is based on New Zealand White rabbits selected since 1980 by a family index for litter 
Chapter V

size at weaning over 45 generations. Line $\mathrm{R}$ comes from the fusion of two lines, one founded in 1976 with Californian rabbits reared by Valencian farmers and another founded in 1981 with rabbits belonging to specialised paternal lines. The selection method was individual selection on post-weaning daily gain, with weaning taking place at 28 days and the end of the fattening at 63 days. All animals were housed at the Animal Technology and Research Centre (CITA-IVIA, Segorbe, Castellón, Spain) experimental farm in flat deck indoor cages $(75 \times 50 \times 30 \mathrm{~cm})$, with free access to water and commercial pelleted diets (minimum of $15 \mathrm{~g}$ of crude protein per $\mathrm{kg}$ of dry matter (DM), $15 \mathrm{~g}$ of crude fibre per kg of DM, and 10.2 MJ of digestible energy per kg of DM). The photoperiod was set to provide $16 \mathrm{~h}$ of light and $8 \mathrm{~h}$ of dark, and the room temperature was regulated to keep temperatures between $14^{\circ} \mathrm{C}$ and $28^{\circ} \mathrm{C}$.

\section{Semen collection and preparation of seminal plasma samples}

Semen samples were obtained by artificial vagina and collected into a sterile tube. One ejaculate was collected per male and week. Collections were performed on the same day of the week during 1 year. Routine diagnostic semen analyses were performed to assess the initial seminal quality. Only ejaculates exhibiting a white colour and possessing more than $70 \%$ of motility, $85 \%$ of intact apical ridge (acrosomal status), and less than $15 \%$ of abnormal sperm were used in this experiment. Then, ejaculates from the same genotype were pooled each day as a single sample. Each sample was centrifuged at $7400 \mathrm{xg}$ for $10 \mathrm{~min}$ at $22 \mathrm{o}$. The resulting supernatants were collected and centrifuged again ( $7400 \times \mathrm{g}$ for $10 \mathrm{~min}$ ) to remove residual spermatozoa and cell debris. The supernatants were collected, supplemented with a $1 \% \mathrm{v} / \mathrm{v}$ protease inhibitor cocktail (P2714, Sigma) and stored at $-80 \circ \mathrm{C}$ until use. 
For each genotype, one pooled sample at the beginning, middle and end of each season was selected to develop the experiment (Fig. 5.1). A total of 24 pools ( 3 for each season and genetic line) were analysed. Total protein concentration was quantified in duplicate by the bicinchoninic acid method (BCA) using BSA as standard protein (Smith et al., 1985) and seminal samples were adjusted to $5 \mu \mathrm{g} / \mu \mathrm{L}$ in saline solution. 
Figure 5.1. Experimental design scheme.
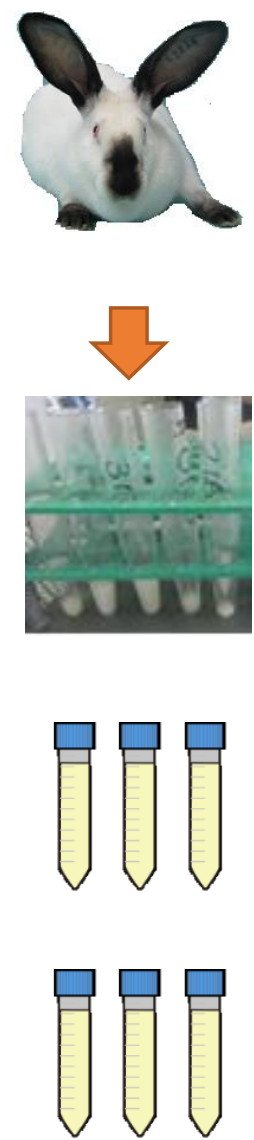

Spring

Winter

Summer
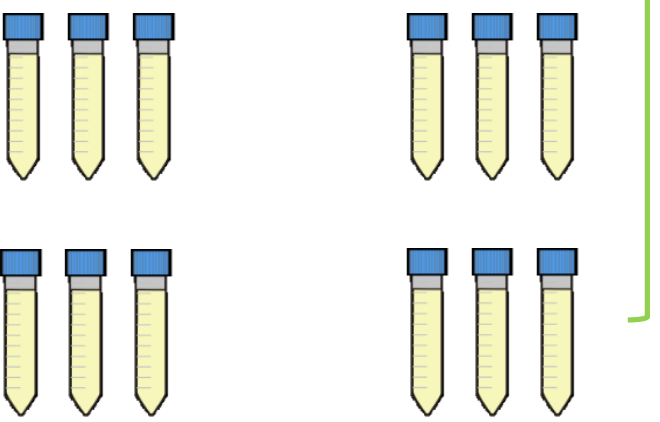

Autumn

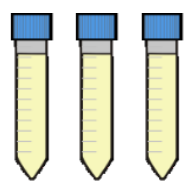

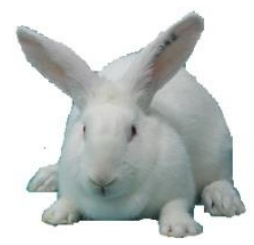

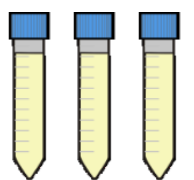

Semen samples were recovered from January to December 2014.
For each genotype, one pooled sample at the beginning, middle and end of each season was selected to develop the experiment. The selected samples were collected the exact same day in both genotypes.
Seminal plasma

from selected

samples was

recovered by

centrifugation.

Three biological replicates were used for each season and genotype and subjected to nano LC/MS-MS. In total, 24 samples were analysed. 


\section{In-solution digestion}

The proteomic analysis was performed in the proteomics facility of SCSIE University of Valencia that belongs to ProteoRed, PRB2-ISCIII, supported by grant PT13/0001. Forty $\mu \mathrm{g}$ of every sample were taken and the volume was set to $22.5 \mu \mathrm{L}$ with $50 \mathrm{mM}$ ammonium bicarbonate $(A B C)$. Samples were digested with $800 \mathrm{ng}$ of sequencing grade trypsin (Promega) according the following steps: (1) the proteins were reduced using $2 \mathrm{mM}$ Dithiothreitol (DTT) reducing agent in $50 \mathrm{mM} \mathrm{NH4HCO3} \mathrm{to} \mathrm{a} \mathrm{final} \mathrm{volume}$ of $25 \mu \mathrm{L}$, being the incubation at 60 으 during 20 minutes; (2) the proteins were alkylated at room temperature using $5.5 \mathrm{mM}$ iodoacetamide (IAM) in $50 \mathrm{mM}$ $\mathrm{NH} 4 \mathrm{HCO} 3$ to a final volume of $30 \mu \mathrm{L}$, being the incubation during 30 minutes in the dark; (3) trypsin was added (800 ng) to a final volume of $38 \mu \mathrm{L}$, the sample was carefully mixed and digestion was carried overnight at $37^{\circ} \mathrm{C}$. The digestion was stopped with $4 \mu \mathrm{L}$ of trifluoroacetic acid (Fisher Scientific; 10\% final concentration). Final tryptic peptides were at $0.9 \mu \mathrm{g} / \mu \mathrm{L}$.

\section{Nano LC-MS/MS analysis}

Two $\mu \mathrm{L}$ of each sample were loaded onto a trap column (nano LC Column, $3 \mu \mathrm{m}$ particles size $\mathrm{C} 18-\mathrm{CL}, 350 \mu \mathrm{m}$ diameter x 0.5mm long; Eksigent Technologies) and desalted with $0.1 \%$ TFA at $3 \mu \mathrm{L} / \mathrm{min}$ during $5 \mathrm{~min}$. The peptides were then loaded onto an analytical column (LC Column, $3 \mu \mathrm{m}$ particles size $\mathrm{C} 18-\mathrm{CL}, 75 \mu \mathrm{m}$ diameter $\mathrm{x} 12 \mathrm{~cm}$ long, Nikkyo) equilibrated in $5 \%$ acetonitrile ( $A C N$ ) $0.1 \%$ formic acid (FA). Peptide elution was carried out with a linear gradient of $5 \%$ to $35 \%$ of solvent B in A for 120 min. (A: $0.1 \%$ FA; $B: A C N, 0.1 \%$ FA) at a flow rate of $300 \mathrm{~nL} / \mathrm{min}$. Peptides were analysed in a mass spectrometer nanoESI qQTOF (5600 TripleTOF, ABSCIEX). 
Chapter V

Eluted peptides were ionized applying $2.8 \mathrm{kV}$ to the spray emitter. The mass spectrometric analysis was carried out in a data-dependent mode. Survey MS1 scans were acquired from $350-1250 \mathrm{~m} / \mathrm{z}$ for $250 \mathrm{~ms}$. The quadrupole resolution was set to 'UNIT' for MS2 experiments, which were acquired from $100-1500 \mathrm{~m} / \mathrm{z}$ for $25 \mathrm{~ms}$ in 'high sensitivity' mode. Following switch criteria were used: charge: $2+$ to 5+; minimum intensity; 70 counts per second (cps). Up to 25 ions were selected for fragmentation after each survey scan. Dynamic exclusion was set to $15 \mathrm{~s}$. The system sensitivity was controlled with $2 \mathrm{fmol}$ of 6 proteins mixture (LC Packings). Samples were injected in a random order.

The proteomics data and result-files from the analysis have been deposited to the ProteomeXchange Consortium via the PRIDE (Vizcaíno et al., 2016) partner repository, with the dataset identifier PXD006308 and 10.6019/PXD006308X.

\section{Protein identification}

The SCIEX.wiff data-files were processed using ProteinPilot v5.0 search engine (AB SCIEX). ProteinPilot default parameters were used to generate peak list directly from 5600 TripleTof wiff files. The Paragon algorithm of ProteinPilot $v 5.0$ was used to search Swiss-Prot (07/01/2017) database with the following parameters: trypsin specificity, cys-alkylation, no taxonomy restriction, and the search effort set to through.

To avoid using the same spectral evidence in more than one protein, the identified proteins are grouped based on MS/MS spectra by the Protein-Pilot Progroup algorithm. A protein group in a Pro Group Report is a set of proteins that share some physical evidence. Unlike sequence alignment analyses where full length theoretical 
sequences are compared, the formation of protein groups in Pro Group is guided entirely by observed peptides only. Since the observed peptides are actually determined from experimentally acquired spectra, the grouping can be considered to be guided by usage of spectra. Then, unobserved regions of protein sequence play no role in explaining the data. Only peptide and protein identifications with $\geq 95 \%$ Confidence (unused Score $\geq 1.3$ ) were validated. Protein identifications were accepted if they contained at least two identified peptides.

\section{Label-free protein quantification using Chromatographic Areas}

For quantification, the group file generated by Protein Pilot was used. The ions areas were extracted from the wiff files obtained from LC-MS/MS experiment by Peak View ${ }^{\circledR}$ v1.1. Only peptides assigned with confidence $\geq 95 \%$, among those without modifications or shared by different proteins were extracted. A total of 24 samples were analysed and 402 proteins were quantified.

\section{Bioinformatics analysis}

Gene ontology terms for biological process, molecular function and cellular component were obtained using UniProt database (http://www.uniprot.org/ accessed on 07/08/2017) in order to retrieve the gene names in combination with PANTHER v11.1 (http://www.pantherdb.org/ accessed on 07/08/2017, Mi et al., 2017), with Homo sapiens as the organism to maximise classifications. 
Chapter V

\section{Statistical analysis}

The quantitative data obtained by PeakView ${ }^{\circledR}$ were analysed by Marker View ${ }^{\circledR}$ v1.3 (AB Sciex). First, areas were normalized by total areas summa. A t-test was used to identify the differentially expressed proteins between genotypes. Proteins were considered differentially expressed if the adjusted $p$-value $<0.05$. Mean quantity of proteins were calculated and the fold-changes between the two groups were estimated. No multiple corrections were performed. The standard deviation was pooled out by calculating a separate $t$ value for each peak. Group comparison is performed by calculating the square of $t$ according to the following equation:

$$
\begin{gathered}
\mathrm{t}^{2}=\left(\left\langle\mathrm{R}_{1}\right\rangle-\left\langle\mathrm{R}_{2}>\right)^{2} /\left(\sigma^{2} / \mathrm{n}_{1}+\sigma^{2} / \mathrm{n}_{2}\right)\right. \\
\text { where } \sigma^{2}=\left[\left(\mathrm{n}_{1}-1\right) \sigma_{1}{ }^{2}+\left(\mathrm{n}_{2}-1\right) \sigma_{2}{ }^{2}\right] /\left(\mathrm{n}_{1}+\mathrm{n}_{2}-2\right)
\end{gathered}
$$

Finally, an estimation of the $\beta$-NGF proportion as percentage of the total seminal plasma protein was calculated by comparing the peak area of $\beta$-NGF protein with the total area of each sample and an ANOVA comparing the $\beta$-NGF proportion between genotypes and seasons was done (STATGRAPHICS ${ }^{\circledR}$ ). Partial Least Squares Discriminant Analysis (PLS-DA) was performed to evaluate the classification of the samples using mixOmics $R$ package and proteins with a vip score $>1.5$ were selected and represented in a heat map.

\section{RESULTS}

\section{Rabbit seminal plasma proteome}

The Proteomics System Performance Evaluation Pipeline (PSPEP) Software was used to perform a false discovery rate analysis on Paragon ${ }^{\mathrm{TM}}$ algorithm results. The complete spectral library included 88,385 spectral corresponding to 4,600 peptides and 402 
proteins validated with $\geq 95 \%$ Confidence (unused Score $\geq 1.3$ ) when using at least 2 peptides for identification (Table S5.1). These 402 proteins were quantified based on their chromatographic or peak areas (Table S5.2).

The complete rabbit seminal plasma proteome was classified under different categories based on their molecular function, biological process and cellular components (PANTHER analysis). The results are shown in Figure 5.2. For molecular function (Fig. 5.2.a), a total of 251 hits were found. The catalytic activity was the predominant function $(50 \%)$, followed by binding $(27 \%)$ and structural molecule activity (13\%). Regarding biological process (Fig. 5.2.b), a total of 471 hits were found. The metabolic (28\%) and the cellular process $(26 \%)$ were the most abundant categories, but it is worth mentioning that 6 hits (1\%) were classified in the category of reproduction specifically to gamete generation and fertilization functions. Finally, a total of 195 hits were found for cellular component category (Fig. 5.2.c). Cell part (52\%), organelle (27\%), macromolecular complex (9\%) and extracellular region (7\%) were the most abundant cellular components of the studied proteins.

Figure 5.2. Pie charts showing the distribution of rabbit seminal plasma proteins based on their a) molecular function, b) biological process and c) cellular component, using UniProt database in combination with PANTHER.

a)

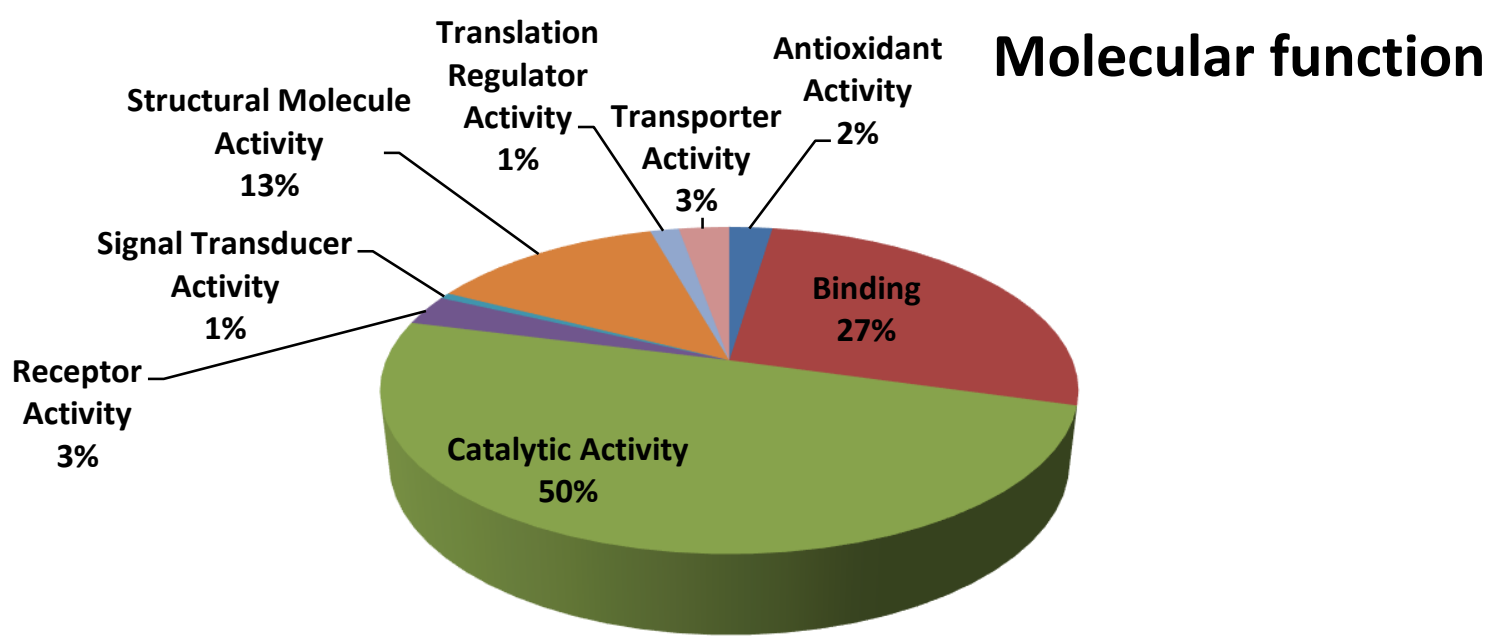


b)

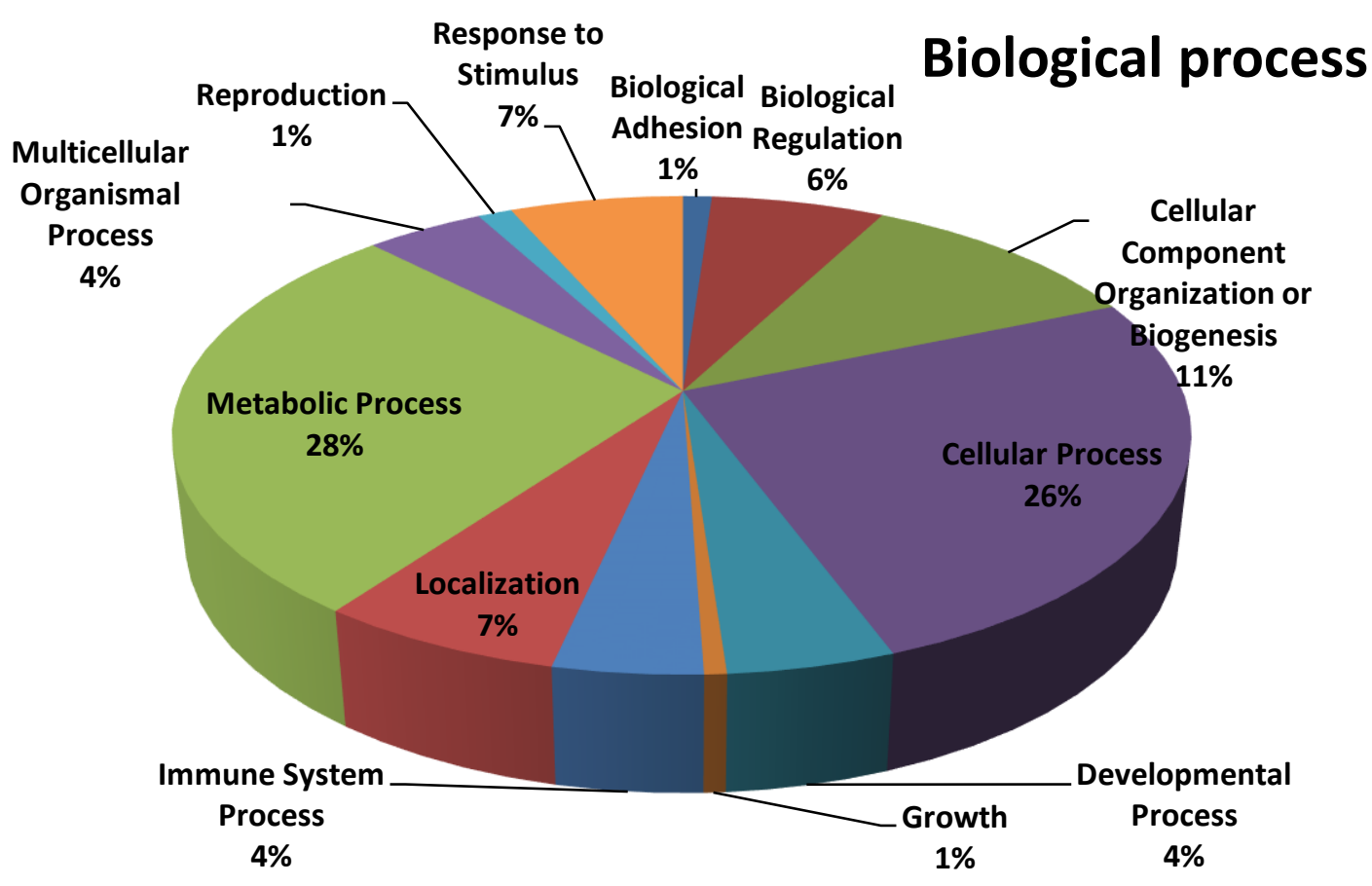

c)

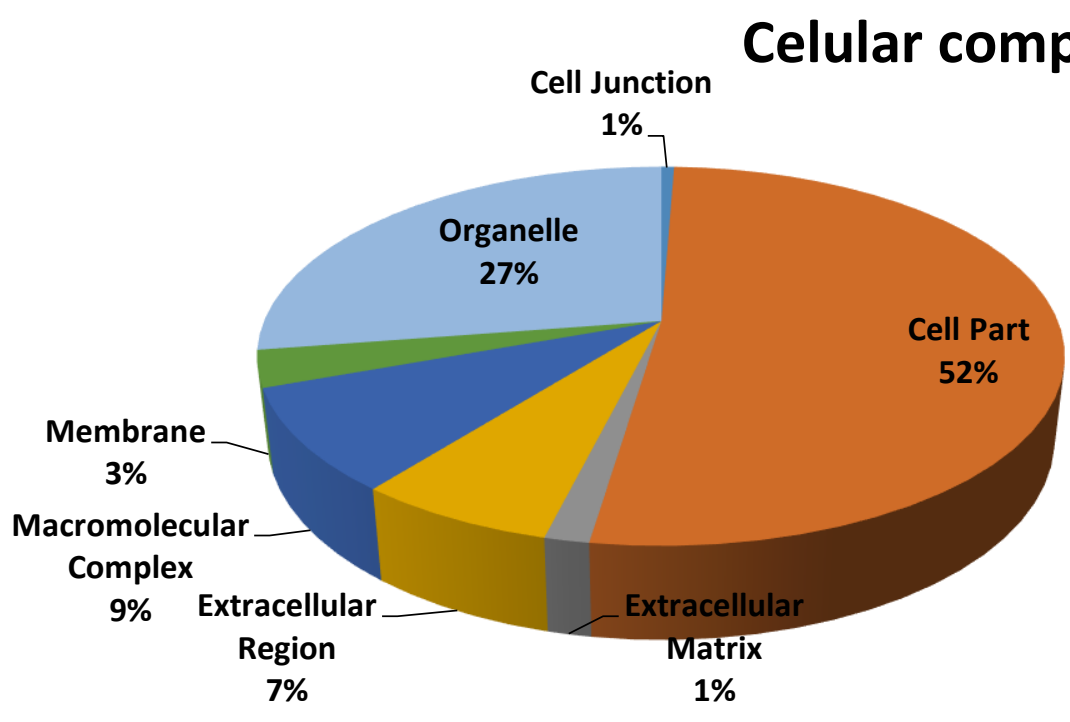

\section{Effect of genetic origin on seminal plasma proteome}

The results of the seminal plasma proteome comparison between both genetic lines ( $\mathrm{A}$ and R) are shown in Fig. 5.3. PLS-DA analysis showed a clear effect of the genetic 
origin. Proteins with a vip score $>1.5$ (high influence in the response variable) were selected and a heat map was generated (Fig. 5.4). The hierarchical clustering of seminal plasma proteins separated the twenty-four seminal samples into two different main clusters, differentiating between genotypes.

Figure 5.3. Partial Least Squares Discriminant Analysis (PLS-DA) showing the classification of seminal samples from genotypes $A$ and $R$, based on relative protein amount.

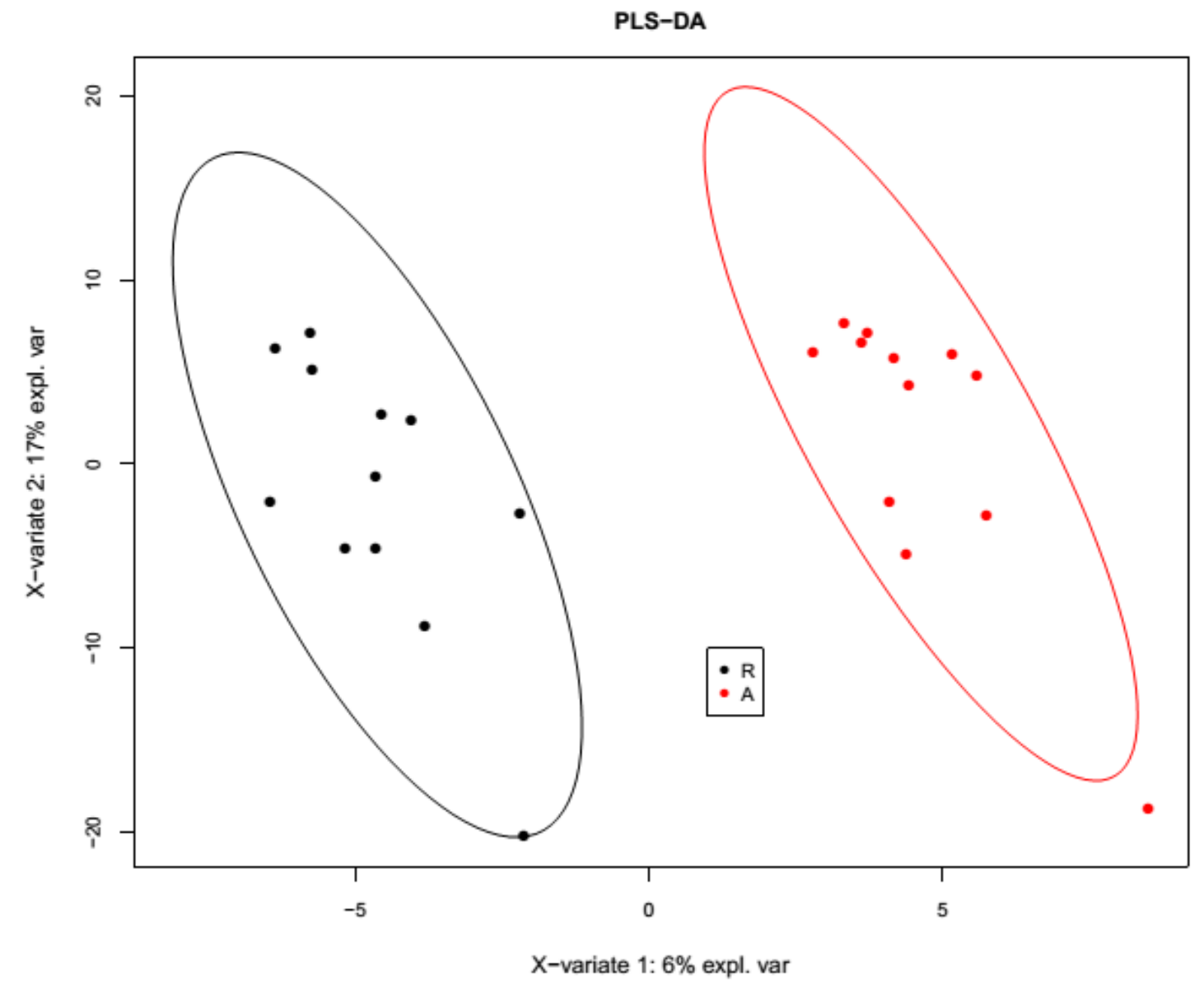


Figure 5.4. Heat map representing levels of differentially expressed seminal plasma proteins between genetic origins $A$ and $R$ and hierarchical clustering, showing two main clusters comprising genotype

A

and

R.

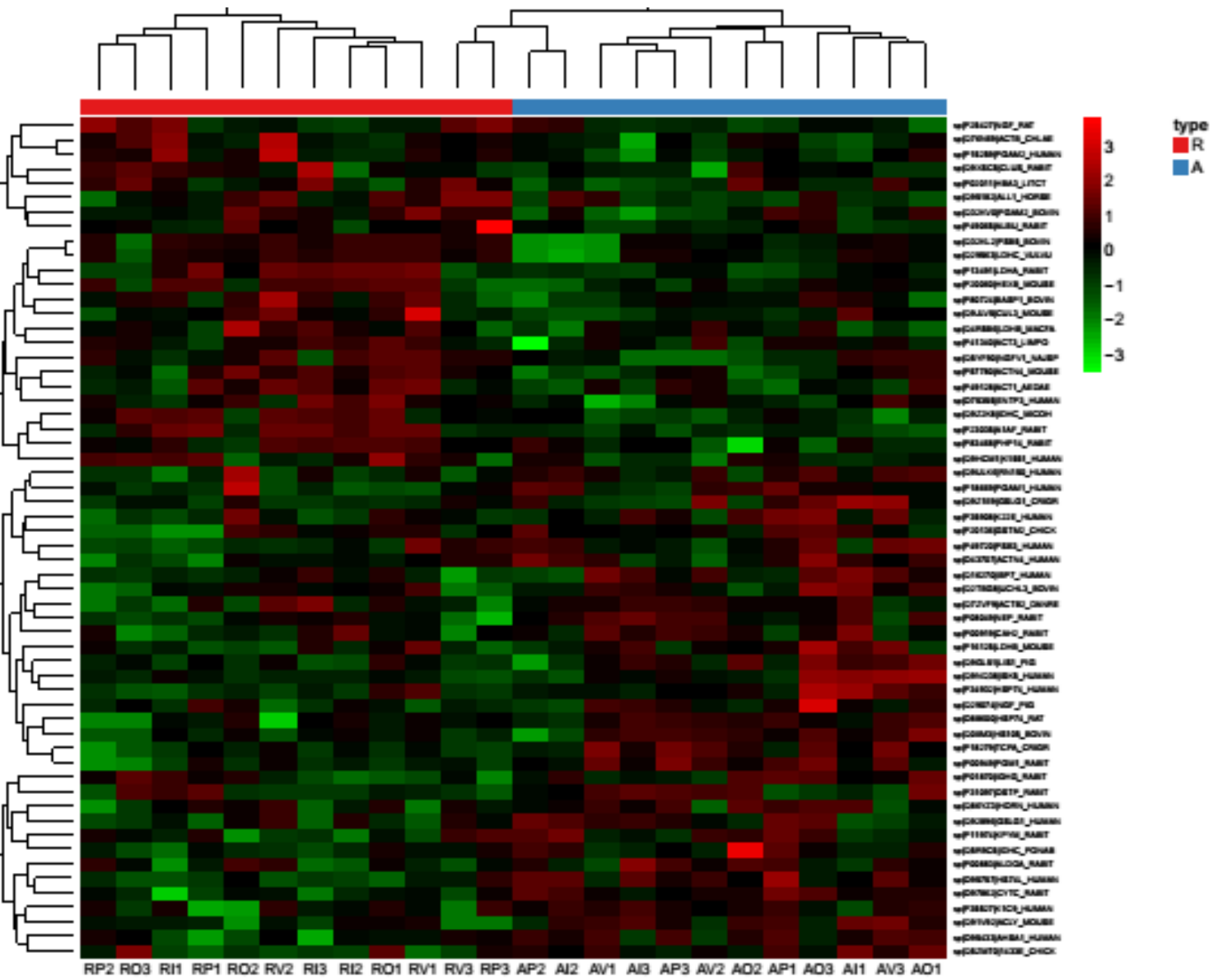

Given that the proteome between both genotypes presented high variability, a t-test was done. Results showed a total of 23 differentially expressed proteins $(p<0.05)$ between genotypes (Table S5.3). Of the differentially expressed proteins, 11 proteins were over-expressed in genetic line $A$ and 12 proteins over-expressed in line $R$ (Table 5.1). 
Table 5.1. List of differentially expressed proteins in rabbit seminal plasma between genotypes $A$ and $R$.

\begin{tabular}{|c|c|c|c|c|c|}
\hline \multirow{2}{*}{ Protein name } & \multirow{2}{*}{$\begin{array}{l}\text { Gene } \\
\text { name }\end{array}$} & \multicolumn{2}{|c|}{ Mean protein amount } & \multirow{2}{*}{$\begin{array}{l}\text { Log (Fold } \\
\text { Change) }\end{array}$} & \multirow{2}{*}{$\begin{array}{c}\mathrm{p}- \\
\text { value }\end{array}$} \\
\hline & & Line A & Line $\mathbf{R}$ & & \\
\hline Elongation factor 4 & lepA & 5971106.95 & 185466.34 & -1.508 & 0.041 \\
\hline Uteroglobin & SCGB1A1 & 5041496.51 & 1589062.14 & -0.501 & 0.004 \\
\hline Zonadhesin & ZAN & 27743.01 & 8848.46 & -0.496 & 0.022 \\
\hline $\begin{array}{l}\text { Peptidyl-prolyl cis- } \\
\text { trans isomerase }\end{array}$ & Fkbp1a & 912341.90 & 343914.90 & -0.424 & 0.043 \\
\hline Plastin-1 & Pls1 & 5001378.19 & 2121482.19 & -0.372 & 0.025 \\
\hline $\begin{array}{l}\text { Ubiquitin carboxyl- } \\
\text { terminal hydrolase } \\
\text { isozyme } \mathrm{L3}\end{array}$ & UCHL3 & 421244.19 & 179445.24 & -0.371 & 0.001 \\
\hline CD109 antigen & CD109 & 163095.41 & 76843.68 & -0.327 & 0.033 \\
\hline Catalase & CAT & 1185007.71 & 610573.83 & -0.288 & 0.006 \\
\hline $\begin{array}{c}\text { Ectonucleoside } \\
\text { triphosphate } \\
\text { diphosphohydrolase } \\
3\end{array}$ & ENTPD3 & 7966888.56 & 4244516.56 & -0.273 & 0.002 \\
\hline $\begin{array}{c}\text { Carbonic anhydrase } \\
2\end{array}$ & CA2 & 9004455.75 & 5035722.69 & -0.252 & 0.000 \\
\hline $\begin{array}{c}\text { Aspartate } \\
\text { aminotransferase }\end{array}$ & GOT1 & 181617.72 & 112819.89 & -0.207 & 0.047 \\
\hline $\begin{array}{l}\text { Heat shock } 70 \mathrm{kDa} \\
\text { protein } 1 \text {-like }\end{array}$ & HSPA1L & 1600299.91 & 2195440.94 & 0.137 & 0.045 \\
\hline $\begin{array}{c}\text { Fructose-1,6- } \\
\text { bisphosphatase } 1\end{array}$ & FBP1 & 999212.40 & 1371171.41 & 0.137 & 0.029 \\
\hline Polyubiquitin-C & UBC & 3011220.72 & 4814226.51 & 0.204 & 0.043 \\
\hline $\begin{array}{l}\text { Peptidyl-glycine } \\
\text { alpha-amidating } \\
\text { monooxygenase }\end{array}$ & PAM & 8091199.72 & 13912767.58 & 0.235 & 0.048 \\
\hline Aldehyde oxidase 3 & Aox3 & 716956.23 & 1488232.49 & 0.317 & 0.002 \\
\hline Insulin-like growth & IGFBP7 & 32046.86 & 68416.81 & 0.329 & 0.049 \\
\hline
\end{tabular}


Chapter V

\begin{tabular}{|c|c|c|c|c|c|}
\hline $\begin{array}{l}\text { Heme-binding } \\
\text { protein } 2\end{array}$ & HEBP2 & 53370.24 & 144433.36 & 0.432 & 0.038 \\
\hline Destrin & DSTN & 32058.12 & 87093.22 & 0.434 & 0.045 \\
\hline Calumenin & CALU & 219223.020 & 1137831.85 & 0.715 & 0.038 \\
\hline Carboxypeptidase Q & $\mathrm{CPQ}$ & 583281.624 & 3847442.484 & 0.819 & 0.002 \\
\hline $\begin{array}{l}\text { ATP-dependent 6- } \\
\text { phosphofructokinase }\end{array}$ & PFKP & 1529350.190 & 23963532.689 & 1.195 & 0.002 \\
\hline $\begin{array}{l}\text { Hemoglobin subunit } \\
\text { alpha-3 }\end{array}$ & HBA3 & 114877.044 & 5472291.847 & 1.678 & 0.008 \\
\hline
\end{tabular}

\section{Effect of season on seminal plasma proteome}

The results of the comparison between seasons are shown in Fig. 5.6. PLS-DA analysis showed unclear separation between seasons, existing overlaps between winter, spring, summer and autumn samples. Seminal samples from autumn seem to be the most differential ones compared with the others; however, half of them overlap with other seasons samples. After applying vip score function to the previous PLS-DA results and only selecting the proteins with a vip score $>1.5$ (high influence in the response variable), a heat map was generated (Fig. 5.7). Predictably, in the heat map, the hierarchical clustering of seminal plasma proteins separated the 24 seminal samples into four different main clusters, but these clusters did not match the four seasons but a mixture of them. 
Figure 5.6. Partial Least Squares Discriminant Analysis (PLS-DA) showing the classification of seminal samples belonging to the four seasons, based on relative protein amount.

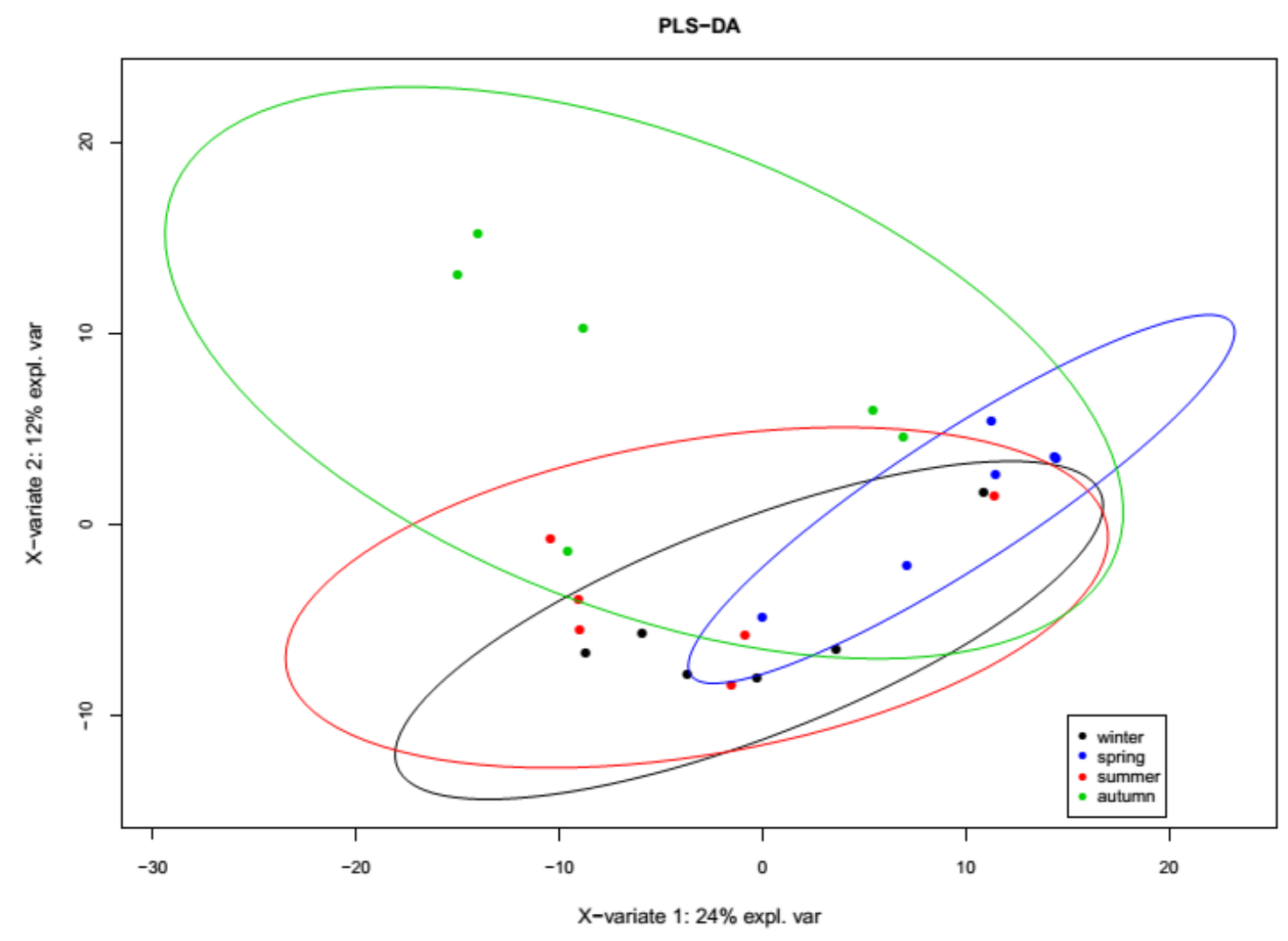




\section{Chapter V}

Figure 5.7. Heat map representing levels of differentially expressed seminal plasma proteins between seasons and hierarchical clustering, showing four main clusters comprising a mixture of samples from different seasons.

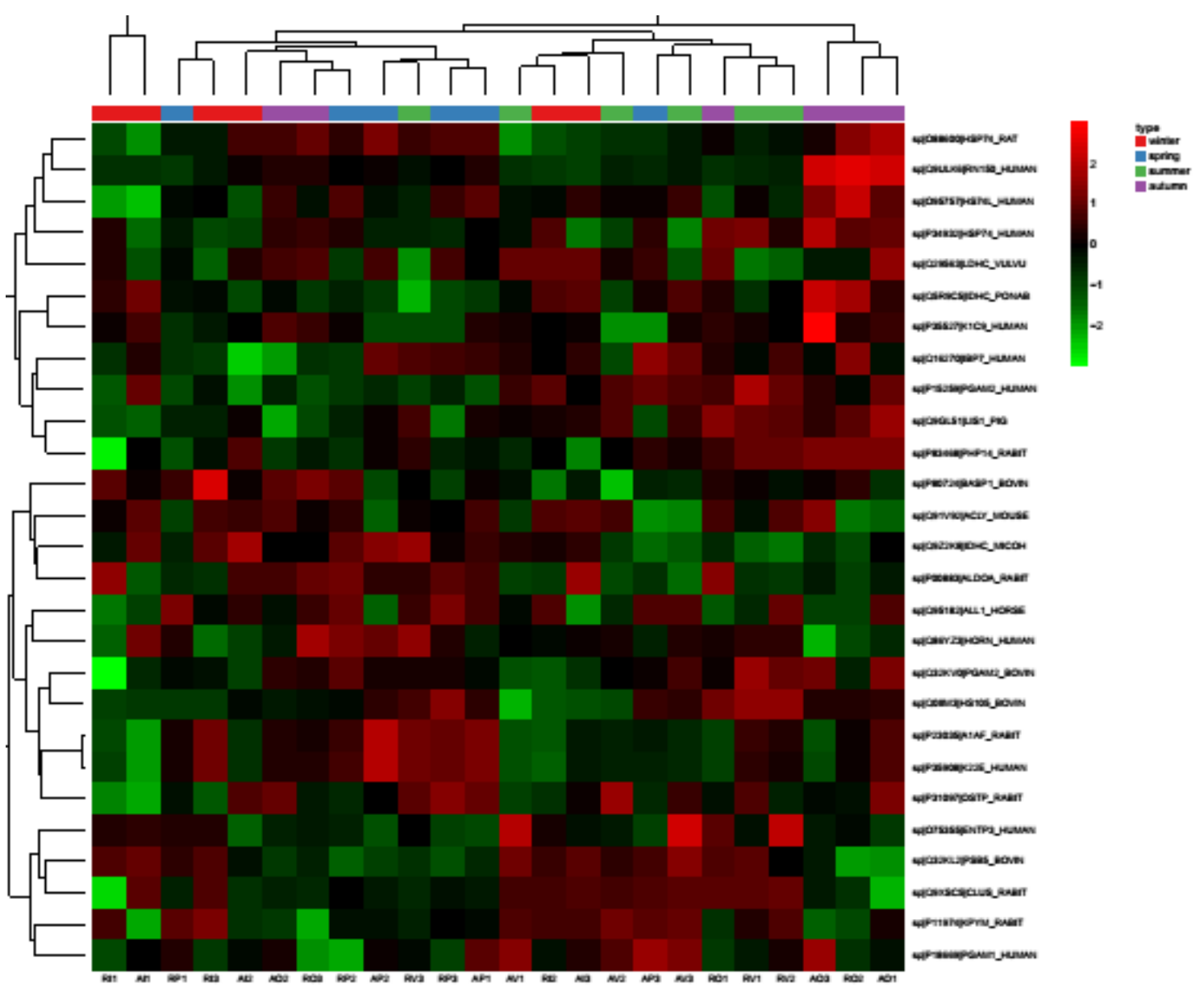

\section{4. $\beta$-NGF relative quantification in rabbit seminal plasma}

The proportion of $\beta$-NGF in rabbit seminal plasma in each season and genotype was the following: winter $(0.96 \%)$, spring $(2.34 \%)$, summer $(1.34 \%)$, autumn $(1.16 \%)$, genotype A (1.41\%) and genotype R (1.49\%). The $\beta$-NGF quantity detected in seminal plasma indicated that neither genetic origin $(p=0.74)$ nor season $(p=0.08)$ have influence on this protein abundance. 


\section{DISCUSSION}

To the best of our knowledge this study generates the largest library of seminal plasma (SP) proteins reported to date in rabbits. Moreover, one of the most important contributions of this study is the significant relationship found between genetic origin and SP proteins in rabbit. In previous studies, rabbit seminal plasma proteome has already been proved different between rabbit genotype $A$ and $R$ (Casares-Crespo et al., 2016a; Safaa et al., 2008; Viudes-de-Castro et al., 2004). In these previous studies a traditional 1-D polyacrylamide gel was done, identifying only major proteins visible after Coomassie Colloidal Blue staining and obtaining the relative quantity of these protein bands through scanning and analysing the gel with $1 \mathrm{D}$ software. The fact that in the present study a more accurate technique such as LC-MS/MS was used in order to identified the differentially expressed proteins, could explain the differences found between previous (Casares-Crespo et al., 2016a; Safaa et al., 2008; Viudes-de-Castro et al., 2004) and current results. Indeed, the exceptional sensitivity and resolving power of today's mass spectrometers allow for the detection of proteins and peptides at low femtomole quantities (Wither et al., 2016). That is why, in the current study, with the application of LC-MS/MS, we identified and quantified 402 rabbit SP proteins, compared to the seven rabbit seminal plasma proteins identified previously (CasaresCrespo et al., 2016a).

Bioinformatics analysis of rabbit SP proteome revealed that $50 \%$ of identified proteins were related to catalytic activity and the second dominant group of proteins was assigned to a binding function (27\%). These proportions agree with previous proteomic studies of human, ram, carp and boar seminal plasma (Dietrich et al., 2014; PérezPatiño et al., 2016; Pilch and Mann, 2006; Souza et al., 2012). Inside the category of 
Chapter V

catalytic activity, the aminopeptidase B protein is included. This enzyme has an important role in rabbit Al because it is responsible for degrading the $\mathrm{GnRH}$ analogue when it is added to the seminal dose to induce doe ovulation. In previous works, we have demonstrated that aminopeptidase activity in rabbit seminal plasma reduces the bioavailability of the GnRH analogue (Viudes-de-Castro et al., 2014) and new extenders with aminopeptidase inhibitors are being developed (Casares-Crespo et al., 2016b, 2017). Regarding biological process, the metabolic (28\%) was the most abundant category in rabbit SP, which coincides with human, carp and boar SP proteins (Dietrich et al., 2014; Pérez-Patiño et al., 2016; Souza et al., 2012). It is also noticeable that only 6 of the 402 proteins identified in rabbit SP are to date recorded in GO as being directly associated with reproductive processes. Similar results were found in boar SP, where only 20 of the 374 proteins identified were annotated as related to reproduction (Pérez-Patiño et al., 2016).

To date, recent research on seminal plasma of major domestic mammalian species (Aquino-Cortez et al., 2017; Druart et al., 2013; Pérez-Patiño et al., 2016; Pini et al., 2016; Souza et al., 2012), human (Pilch and Mann, 2006) and fish (Dietrich et al., 2014; Gombar et al., 2017; Nynca et al., 2017), including semen quality (Sarsaifi et al., 2015), fertilizing markers (Kwon et al., 2015) and freezability (Dietrich et al., 2017; Vilagran et al., 2015) have been reported. Nevertheless, it is unknown at present if there is a variation in seminal plasma protein composition among genotypes within the same species. Our results clearly indicate that SP proteins abundance in rabbit seems to be related to a specific genotype, which in several previous studies have demonstrate differences in sperm quality, fertility and prolificacy (Safaa et al., 2008; Vicente et al., 2000). As stated, we identified a higher abundance of 11 proteins in genotype $A$ 
seminal plasma, while another 12 proteins were more abundant in genotype $\mathrm{R}$ seminal plasma.

Among the over-expressed proteins in genotype A, we find uteroglobin and zonadhesin. Uteroglobin has been identified in rabbit seminal plasma and in rabbit uterus secretions (Kirchner and Schroer, 1976; Müller, 1983) and zonadhesin in spermatozoa (Lea et al., 2001), but their role remains unknown to date. While uteroglobin, also present in the prostate, may be responsible for suppressing sperm antigenicity in the rabbit (Mukherjee et al., 1983), zonadhesin is located exclusively in the anterior acrosome and may be one of the proteins that anchors the acrosomal shroud to the zona pellucida (http://www.uniprot.org/uniprot/P57999), thereby allowing the spermatozoa to continue penetration and fertilization to proceed spermatozoa (Lea et al., 2001). In addition, we also observed a greater amount of ectonucleoside triphosphate diphosphohydrolase 3 protein, which agrees with the results of a previous study (Casares-Crespo et al., 2016a) and has been related with acrosome alteration when it concentration decreased (Taha et al., 2011). All of these findings, especially the increased amount of these proteins observed in genotype $A$ in comparison with genotype $\mathrm{R}$ could explain in part the better acrosome integrity of spermatozoa and the enhanced fertility and prolificacy previously described in genotype A (Lavara et al., 2005; Safaa et al., 2008).

Other over-expressed proteins in line A such as plastin 1 and ubiquitin carboxylterminal hydrolase have been found related to spermatogenesis in other species (Kwon et al., 2004; Li et al., 2015). Plastins are a family of actin binding proteins known to cross-link actin microfilaments in mammalian cells, creating actin microfilament bundles necessary to confer cell polarity and cell shape (Li et al., 2016). There are three 
Chapter V

types of plastins: plastin 1, 2, and 3. All three are expressed in Sertoli cells and plastin 1 and 2 in testes germ cells (Li et al., 2016). Plastin protein has been found in boar seminal plasma exosomes (Piehl et al., 2013) and in rat testis (Li et al., 2015). Plastin 1 deficient mice were fertile and displayed a normal reproductive rate (Grimm-Gunter et al., 2009), what suggests an additional role of plastin far from the fertility process. On the other hand, ubiquitin carboxyl-terminal hydrolase isozyme 3 may function in the meiotic differentiation of spermatocytes into spermatids (Kwon et al., 2004).

Seminal plasma contains antioxidants that are free radical scavengers that protect sperm cells against oxidative stress (Bousnane et al., 2017). For instance, catalase serves to protect cells from the toxics effects of hydrogen peroxide (http://www.uniprot.org/uniprot/Q64405). In bulls, the levels of catalase in seminal plasma have been found higher in high-fertile males than in subfertile bulls (Kumar et al., 2016). In addition, the supplementation of post-thawed rooster semen with 100 $\mu \mathrm{g} / \mathrm{mL}$ of catalase has beneficial effects on semen quality (Amini et al., 2015). In line with this, the protein named elongation factor 4 is required for accurate and efficient $\begin{array}{llll}\text { protein } & \text { synthesis under certain } & \text { stress }\end{array}$ (http://www.uniprot.org/uniprot/Q5KWZ3). Therefore, the over-expression of catalase and elongation factor 4 proteins in seminal plasma of genotype $A$ supports the better recovery and performance of thawed semen from genotype A compared to $R$ (Mocé et al., 2003).

The rest of the over-expressed proteins in line A were enzymes such as carbonic anhydrase 2 , which has been found to have a role in the regulation of bicarbonate concentration in horse seminal plasma and accordingly regulate seminal plasma $\mathrm{pH}$ (Asari et al., 1996), aspartate aminotransferase (AST) which is an important regulator 
of glutamate (http://www.uniprot.org/uniprot/P33097) and peptidyl-prolyl cis-trans isomerise which keeps in an inactive conformation of the TGF-beta type I serine/threonine kinase receptor, preventing TGF-beta receptor activation in absence of ligand (http://www.uniprot.org/uniprot/P26883).

On the other hand, genotype R presents higher abundance in several proteins related with reproductive function such as insulin-like growth factor-binding protein 7 which is important for correct spermatogenesis (Belardin et al., 2016) and polyubiquitin C which is involved in sperm-zona pellucida interactions and antipolyspermy defense in pig (Yi et al., 2007). Besides, genotype $\mathrm{R}$ seminal plasma has more quantity of Heat shock $70 \mathrm{kDa}$ 1-like protein. Heat shock proteins (70 and $90 \mathrm{kDa}$ ) are chaperones implicated in a wide variety of cellular processes, including protection of the proteome from stress, folding and transport of newly synthesized polypeptides, activation of proteolysis of misfolded proteins and the formation and dissociation of protein complexes (http://www.uniprot.org/uniprot/POCB32). In several species like porcine, ovine and bovine, heat shock $70 \mathrm{kDa}$ protein 8 was found to prolong the survival of spermatozoa at body temperature in vitro (Elliot et al., 2009; Lloyd et al., 2009). The greater abundance of this heat shock protein in line $R$ could explain the better performance of line R spermatozoon when they are stored in vitro during several days (unpublished work, ICTA, 2016). Based on the foregoing, our results provide evidence that genotype has a clear effect on seminal plasma protein abundance.

Regarding the effect of the season on the rabbit seminal plasma proteome, a previous study showed a season effect on the abundance of three proteins (FAM115E-like, haemoglobin subunit zetalike and nerve growth factor) (Casares-Crespo et al., 2016a), but again, these relative quantity protein differences were obtained with a less 
Chapter V

resolute proteomic technique. In the current work, results showed that there are slight protein differences between seasons but it does not exist a clear pattern of protein variation between genotypes. This lack of variation could be explained by the controlled environmental conditions used in our study where animals were kept under $16 \mathrm{~h}$ light/ $8 \mathrm{~h}$ dark and maintained between $14^{\circ} \mathrm{C}$ and $28^{\circ} \mathrm{C}$ using cooling and heating systems over the year.

Finally, we determined the variation of $\beta-N G F$ in rabbit seminal plasma. $\beta$-NGF quantity in other reflexively ovulating species such as llama represents $30 \%$ of the total seminal plasma protein content (20 mg/ejaculate) (Berland et al., 2016), whereas in rabbit seminal plasma it only represents about $1.4 \%$, independently of the genotype. Kershaw-Young et al. (2012) observed that intramuscular administration of llama seminal plasma (equivalent to $<1 / 4$ of an ejaculate) resulted in high rate ovulation induction of females ( $94 \%$ compared to $0 \%$ when saline was administered). Interestingly, in other works, the intramuscular administration of rabbit seminal plasma induced ovulation in llamas, but not in rabbits (Silva et al., 2011). The low proportion of $\beta$-NGF protein in rabbit seminal plasma and the fact that this protein is also present in a relatively low proportion in the seminal plasma of the majority of spontaneous ovulators (Druart et al., 2013), could lead us to think that $\beta$-NGF may have different function. In cows, Stewart et al. (2018) have shown that $\beta$-NGF from bull seminal plasma enhances corpus luteum formation and conceptus development. On the other hand, Maranesi et al. (2015) hypothetized that the role of $\beta$-NGF protein in rabbit seminal plasma may be related to the modulation of the ovulation/fertilization events. Moreover, $\beta$-NGF concentration in rabbit seminal plasma decreased in winter compared to the other seasons, which agrees with the results of a previous study 
(Casares-Crespo et al., 2016a). This may be related to the natural reluctance of rabbits to breed in the early winter and it accords with Zhang et al. (2015) findings in wild ground squirrels, which showed that the production of NGF in testes was decreased during the non-breeding season and increased in the breeding season.

\section{CONCLUSIONS}

In summary, the present study provides the largest catalogue of rabbit seminal plasma proteins to date and generates a public accessible database of rabbit seminal plasma proteome. Gene ontology analysis of the rabbit complete proteome showed the functional diversity of seminal plasma proteins, with only six of them known to be involved in reproduction processes. Additionally, our data provide evidence that genotype is related to a specific abundance of seminal plasma proteins in rabbit. Thus, upon further validation in other species, the results of the present study intend to be a starting point in the development of specifics extenders for each genotype preventing sperm premature oxidation or selecting GnRH analogues with different amino acid composition less sensitive to enzyme degradation of rabbit seminal plasma proteins. In addition, the comparison of seminal plasma proteins between fertile and subfertile rabbit males, could lead to the identification of fertility biomarkers which could be used to detect subfertile males in commercial rabbit farming. Furthermore, a study of rabbit sperm membrane proteome would be interesting in the future to complete the proteomic information about rabbit sperm. 
Chapter V

\section{REFERENCES}

Adams GP, Ratto MH. Ovulation-inducing factor in seminal plasma: a review. Anim. Reprod. Sci. 2013;136:148-56.

Ain-Baziz H, Boulbina I, Ilès I, Belabbas R, Zenia S, Temim S. Influence of environmental temperature and relative humidity on semen characteristics in male rabbit (Oryctolagus cuniculus) of local Algerian population. In Proc: $10^{\text {th }}$ World Rabbit Congress, September 3 - 6, 2012- Sharm El- Sheikh -Egypt, pp 347-350.

Amini MR, Kohram H, Zare-Shahaneh A, Zhandi M, Sharideh H, Nabi MM. The effects of different levels of catalase and superoxide dismutase in modified Beltsville extender on rooster post-thawed sperm quality. Cryobiology 2015;70:226-32.

Aquino-Cortez A, Pinheiro BQ, Lima DBC, Silva HVR, Mota-Filho AC, Martins JAM, Rodriguez-Villamil P, Moura AA, Silva LDM. Proteomic characterization of canine seminal plasma. Theriogenology 2017;95:178-86.

Arruda-Alencar JM, Viana-Neto AM, Souza CEA, Martins JAM, Moreno FB, Moreira ACM, et al. Major proteins of the seminal plasma of New Zealand white rabbits and association with semen criteria. $10^{\text {th }}$ World Rabbit Congress. Sharm El-Sheikh, Egypt: World Rabbit Science Association; 2012. pp 395-9.

Asari M, Sasaki K, Miura K, Ichihara N, Nishita T. Immunohistolocalization of the carbonic anhydrase isoenzymes (CA-I, CA-II, and CA-III) in the reproductive tract of male horses. Am. J. Vet. Res. 1996;57:439-43.

Berland MA, Ulloa-Leal C, Barría M, Wright H, Dissen GA, Silva ME, Ojeda SR, Ratto MH. Seminal plasma induces ovulation in llamas in the absence of a copulatory stimulus: role of nerve growth factor as an ovulation-inducing factor. Endocrinology 2016;157 (8):3224-32. 
Belardin LB, Del Giudice PT, Camargo M, Intasqui P, Antoniassi MP, Bertolla RP, Cedenho AP. Alterations in the proliferative/apoptotic equilibrium in semen of adolescents with varicocele. J. Assist. Reprod. Genet. 2016;33:1657-64.

Boiti C, Castellini C, Besenfelder U, Theau-Clément M, Liguori L, Renieri T, Pizzi F. Guidelines for the handling of rabbit bucks and semen. World Rabbit Science 2005;13:71-91.

Bousnane NEH, May S, Yahia M, Abu Alhaija AA. Association of CAT-262C/T with the concentration of catalase in seminal plasma and the risk for male infertility in Algeria. Systems Biology in Reproductive Medicine 2017:1-8.

Bromfield JJ. A role for seminal plasma in modulating pregnancy outcomes in domestic species. Reproduction 2016;152(6):R223-R232.

Casares-Crespo L, Fernández-Serrano P, Vicente JS, Mocé E, Castellini C, Stabile AM, Viudes-de-Castro M.P. Insemination extender supplementation with bestatin and EDTA has no effect on rabbit reproductive performance. Theriogenology 2018;105:61-65.

Casares-Crespo L, Talaván AM, Viudes-de-Castro MP. Can the Genetic Origin Affect Rabbit Seminal Plasma Protein Profile along the Year? Reprod. Domest. Anim. 2016a;51:294-300.

Casares-Crespo L, Vicente JS, Talaván AM, Viudes-de-Castro MP. Does the inclusion of protease inhibitors in the insemination extender affect rabbit reproductive performance? Theriogenology 2016b;85:928-932.

Castellini C. Semen production and management of rabbit bucks. $9^{\text {th }}$ World Rabbit Congress - June 10-13, 2008 - Verona - Italy; pp 265-278. 
Chapter V

Castellini C, Cardinali R, Dal Bosco A, Minelli A, Camici O. Lipid composition of the main fractions of rabbit semen. Theriogenology 2006;65(4):703-12.

Castellini C, Lattaioli P, Moroni M, Minelli A. Effect of seminal plasma on the characteristics and fertility of rabbit spermatozoa. Anim. Reprod. Sci. 2000;63:275282.

Castellini C, Mattioli S, Ruggeri S, Dal Bosco A, Collodel G. The time-dependent effects of prostate granules and seminal plasma on the capacitation, acrosome reaction, and motility of rabbit sperm. Anim. Reprod. Sci. 2013;140(1-2):97-102.

Castellini C, Mourvaki E, Cardinali R, Collodel G, Lasagna E, Del Vecchio MT, Dal Bosco, A. Secretion patterns and effect of prostate-derived granules on the sperm acrosome reaction of rabbit buck. Theriogenology 2012;78(4):715-23.

Collodel G, Cardinali R, Moretti E, Mattioli S, Ruggeri S, Castellini C. Role of rabbit prostate granules on sperm viability and acrosome reaction evaluated with different methods. Theriogenology 2012;77(5):1021-6.

Dacheux JL, Gatti JL, Dacheux F. Contribution of epididymal secretory proteins for spermatozoa maturation. Microscopy Research And Technique 2003;61:7-17.

Davis BK, Davis NV. Binding by glycoproteins of seminal plasma membrane vesicles accelerates decapacitation in rabbit spermatozoa. Biochim. Biophys. 1983;727:7076.

de Lamirande E, Bardin CW, Gagnon C. Aprotinin and a seminal plasma factor inhibit the motility of demembranated reactivated rabbit spermatozoa. Biol. Reprod. 1983;28:788-796. 
Dietrich MA, Arnold GJ, Nynca J, Frohlich T, Otte K, Ciereszko A. Characterization of carp seminal plasma proteome in relation to blood plasma. Journal of Proteomics 2014;98:218-232.

Dietrich MA, Irnazarow I, Ciereszko A. Proteomic identification of seminal plasma proteins related to the freezability of carp semen. Journal of Proteomics 2017;162:52-61.

Druart X, Rickard JP, Mactier S, Kohnke PL, Kershaw-Young CM, Bathgate R, Gibb Z, Crossett B, Tsikis G, Labas V, Harichaux G, Grupen CG, de Graaf SP. Proteomic characterization and cross species comparison of mammalian seminal plasma. Journal of Proteomics 2013;91:13-22.

Elliott RM, Lloyd RE, Fazeli A, Sostaric E, Georgiou AS, Satake N, Watson PF, Holt WV. Effects of HSPA8, an evolutionarily conserved oviductal protein, on boar and bull spermatozoa. Reproduction 2009;137:191-203.

Fischer B, Chavatte-Palmer P, Viebahn C, Navarrete Santos A, Duranthon V. Rabbit as a reproductive model for human health. Reproduction 2012;144(1) 1-10.

Gombar R, Pitcher TE, Lewis JA, Auld J, Vacratsis PO. Proteomic characterization of seminal plasma from alternative reproductive tactics of Chinook salmon (Oncorhynchus tswatchysha). Journal of Proteomics 2017;157:1-9.

González-Cadavid V, Martins JA, Moreno FB, Andrade TS, Santos AC, Monteiro-Moreira AC, Moreira RA, Moura AA. Seminal plasma proteins of adult boars and correlations with sperm parameters. Theriogenology 2014;82:697-707.

Grimm-Gunter EM, Revenu C, Ramos S, Hurbain I, Smyth N, Ferrary E, Louvard D, Robine S, Rivero F. Plastin 1 binds to keratin and is required for terminal web assembly in the intestinal epithelium. Mol. Biol. Cell. 2009;20:2549-62. 
Chapter V

Hansen PJ. Current and future assisted reproductive technologies for mammalian farm animals. Adv. Exp. Med. Biol. 2014;752:1-22.

Kershaw-Young CM, Druart X, Vaughan J, Maxwell WM. Beta-Nerve growth factor is a major component of alpaca seminal plasma and induces ovulation in female alpacas. Reprod. Fertil. Dev. 2012;24:1093-7.

Kirchner C, Schroer HG. Uterine secretion-like proteins in the seminal plasma of the rabbit. J. Reprod. Fertil. 1976;47:325-30.

Kumar P, Saini M, Kumar D, Bharadwaj A, Yadav P. Estimation of endogenous levels of osteopontin, total antioxidant capacity and malondialdehyde in seminal plasma: Application for fertility assessment in buffalo (Bubalus bubalis) bulls. Reprod. Domest. Anim. 2017;52(2):221-226.

Kwon J, Wang YL, Setsuie R, Sekiguchi S, Sakurai M, Sato Y, Lee WW, Ishii Y, Kyuwa S, Noda M, Wada K, Yoshikawa Y. Developmental regulation of ubiquitin C-terminal hydrolase isozyme expression during spermatogenesis in mice. Biol. Reprod. 2004;71:515-21.

Kwon WS, Oh SA, Kim YJ, Rahman MS, Park YJ, Pang MG. Proteomic approaches for profiling negative fertility markers in inferior boar spermatozoa. Sci. Rep. $2015 ; 5: 13821$.

Lavara R, Moce E, Lavara F, Viudes de Castro MP, Vicente JS. Do parameters of seminal quality correlate with the results of on-farm inseminations in rabbits?. Theriogenology 2005;64:1130-41.

Lavon U. Characterization of boar, bull, ram and rabbit seminal plasma proteins by gel disc electrophoresis and isoelectric focusing on polyacrylamide. J. Reprod. Fertil. 1972;31(1):29-37. 
Lea IA, Sivashanmugam P, O'Rand MG. Zonadhesin: characterization, localization, and zona pellucida binding. Biol. Reprod. 2001;65:1691-700.

Li N, Mruk DD, Wong CK, Lee WM, Han D, Cheng CY. Actin-bundling protein plastin 3 is a regulator of ectoplasmic specialization dynamics during spermatogenesis in the rat testis. FASEB J. 2015;29:3788-805.

Li C, Sun Y, Yi K, Ma Y, Sun Y, Zhang W, Zhou X. Detection of nerve growth factor (NGF) and its specific receptor (TrkA) in ejaculated bovine sperm, and the effects of NGF on sperm function. Theriogenology 2010;74:1615-1622.

Li N, Wong CK, Cheng CY. Plastins regulate ectoplasmic specialization via its actin bundling activity on microfilaments in the rat testis. Asian J. Androl. 2016;18:71622.

Lloyd RE, Elliott RM, Fazeli A, Watson PF, Holt WV. Effects of oviductal proteins, including heat shock $70 \mathrm{kDa}$ protein 8 , on survival of ram spermatozoa over $48 \mathrm{~h}$ in vitro. Reprod. Fertil. Dev. 2009;21:408-18.

Manjunath P, Bergeron A, Lefebvre J, Fan J. Seminal plasma proteins: functions and interaction with protective agents during semen preservation. Soc. Reprod. Fertil. Suppl. 2007;65:217-228.

Marai IFM, Habeeb AAM, Gad AE. Rabbits' productive, reproductive and physiological performance traits as affected by heat stress: a review. Livestock Production Science 2002;78(2):71-90.

Maranesi M, Zerani M, Leonardi L, Pistilli A, Arruda-Alencar J, Stabile AM, Rende M, Castellini C, Petrucci L, Parillo F, Moura A, Boiti C. Gene Expression and Localization of NGF and Its Cognate Receptors NTRK1 and NGFR in the Sex Organs of Male Rabbits. Reprod. Domest. Anim. 2015;50(6):918e25. 
Chapter V

McGraw LA, Suarez SS, Wolfner MF. On a matter of seminal importance: The emerging influence of seminal plasma components on fertility and future progeny. BioEssays: news and reviews in molecular, cellular and developmental biology 2015;37(2):142147.

Mi H, Huang X, Muruganujan A, Tang H, Mills C, Kang D, Thomas PD. PANTHER version 11: expanded annotation data from Gene Ontology and Reactome pathways, and data analysis tool enhancements. Nucleic Acids Res. 2017;45:D183-9.

Minelli A, Moroni M, Castellini C. Isolation and purification of the IGF-I protein complex from rabbit seminal plasma: effects on sperm motility and viability. J. Exp. Zool. 2001;290:279-290.

Mocé E, Vicente JS, Lavara R. Effect of freezing-thawing protocols on the performance of semen from three rabbit lines after artificial insemination. Theriogenology 2003;60:115-23.

Muiño-Blanco T, Pérez-Pé R, Cebrián-Pérez J. Seminal plasma proteins and sperm resistance to stress. Reprod. Domest. Anim. 2008;43:18-31.

Mukherjee DC, Agrawal AK, Manjunath R, Mukherjee AB. Suppression of epididymal sperm antigenicity in the rabbit by uteroglobin and transglutaminase in vitro. Science 1983;219:989-91.

Müller B. Studies on proteins identical to male and female genital tract secretions. Andrologia 1983;15:183-92.

Nizza A, Di Meo C, Taranto S. Effect of Collection Rhythms and Season on Rabbit Semen Production. Reprod. Domest. Anim. 2003;38(6):436-439. 
Nynca J, Arnold G, Fröhlich T, Ciereszko A. Proteomic identification of rainbow trout blood plasma proteins and their relationship to seminal plasma proteins. Proteomics 2017;17(11):doi: 10.1002/pmic.201600460.

Okabe M, Kishi Y, Ying X, Kohama Y, Mimura T, Li SS. Characterization of capacitation inhibitory protein from rabbit seminal plasma: homology with human annexins. Biological \& pharmaceutical bulletin 1993;16:453-456.

Pascual JJ, García C, Martínez E, Mocé E, Vicente JS. Rearing management of rabbit males selected by high growth rate: the effect of diet and season on semen characteristics. Reprod. Nutr. Dev. 2004;44:49-63.

Pascual JJ, Marco-Jiménez F, Martínez-Paredes E, Ródenas L, Fabre C, Juvero MA, Cano JL. Feeding programs promoting daily feed intake stability in rabbit males reduce sperm abnormalities and improve fertility. Theriogenology 2016;86(3):730-7.

Pérez-Patiño C, Barranco I, Parrilla I, Valero ML, Martínez EA, Rodríguez-Martínez H, Roca J. Characterization of the porcine seminal plasma proteome comparing ejaculate portions. Journal of Proteomics 2016;142:15-23.

Piehl LL, Fischman ML, Hellman U, Cisale H, Miranda PV. Boar seminal plasma exosomes: effect on sperm function and protein identification by sequencing. Theriogenology 2013;79:1071-82.

Pilch B, Mann M. Large-scale and high-confidence proteomic analysis of human seminal plasma. Genome Biol. 2006;7:R40.

Piles $M$, Tusell L, Lavara $R$, Baselga $M$. Breeding programmes to improve male reproductive performance and efficiency of insemination dose production in paternal lines: feasibility and limitations. World Rabbit Science 2013;21:61-75. 
Chapter V

Pini T, Leahy T, Soleilhavoup C, Tsikis G, Labas V, Combes-Soia L, Harichaux G, Rickard JP, Druart X, de Graaf SP. Proteomic Investigation of Ram Spermatozoa and the Proteins Conferred by Seminal Plasma. Journal of Proteome Research 2016;15:3700-11.

Roca J, Martínez E, Sánchez-Valverde MA, Ruiz S, Vázquez JM. Seasonal variations of semen quality in male goats: study of sperm abnormalities. Theriogenology $1992 ; 38: 115-25$.

Rodríguez-Martínez H, Kvist U, Ernerudh J, Sanz L, Calvete JJ. Seminal plasma proteins: what role do they play? American Journal of Reproductive Immunology 2011;66:1122.

Sabés-Alsina M, Planell N, Torres-Mejia E, Taberner E, Maya-Soriano MJ, Tusell L, Ramon J, Dalmau A, Piles M, López-Bejar M. Daily exposure to summer circadian cycles affects spermatogenesis, but not fertility in an in vivo rabbit model. Theriogenology 2015;83:246-252.

Safaa HM, Vicente JS, Lavara R, Viudes-de-Castro MP. Semen evaluation of two selected lines of rabbit bucks. World Rabbit Science 2008;16:141-148.

Sarsaifi K, Haron AW, Vejayan J, Yusoff R, Hani H, Omar MA, Hong LW, Yimer N, Ju TY, Othman A. Two-dimensional polyacrylamide gel electrophoresis of Bali bull (Bos javanicus) seminal plasma proteins and their relationship with semen quality. Theriogenology 2015;84:956-68.

Schneidgenová M, Vašíček J, Čupka P, Chrenek P. Is it necessary to control seasonal quality of the rabbit ejaculate? Slovak J. Anim. Sci. 2011;44(2):48-51. 
Silva M, Nino A, Guerra M, Letelier C, Valderrama XP, Adams GP, Ratto MH. Is an ovulation-inducing factor (OIF) present in the seminal plasma of rabbits?. Anim. Reprod. Sci. 2011;127:213-21.

Smith PK, Krohn RI, Hermanson GT, Mallia AK, Gartner FH, Provenzano MD, Fujimoto EK, Goeke NM, Olson BJ, Klenk DC. Measurement of protein using bicinchoninic acid. Anal. Biochem. 1985;150:76-85.

Souza CE, Rego JP, Lobo CH, Oliveira JT, Nogueira FC, Domont GB, Fioramonte M, Gozzo FC, Moreno FB, Monteiro-Moreira AC, Figueiredo JR, Moura AA. Proteomic analysis of the reproductive tract fluids from tropically-adapted Santa Ines rams. Journal of Proteomics 2012;75:4436-56.

Stewart JL, Mercadante VRG, Dias NW, Canisso IF, Yau P, Imai B, Lima FS. Nerve Growth Factor-Beta, purified from bull seminal plasma, enhances corpus luteum formation and conceptus development in Bos taurus cows. Theriogenology 2018;106(15):30-38.

Taha TA, Shaaban WF, EL-Nouty FD, Salem MH. Molecular approach of gossypolinduced reproductive toxicity in male rabbits. Electrophoretic pattern of seminal plasma proteins. Egyptian J. Anim. Prod. 2011;48(2):217-230.

Theau-Clément M, Ailloud E, Sánchez A, Saleil G, Brun JM. Relationships between rabbit semen characteristics and fertilising ability after insemination. Animal 2016;10(3):426-31.

Theau-Clement M, Bolet G, Sánchez A, Saleil G, Brun JM. Some factors that influence semen characteristics in rabbits. Anim. Reprod. Sci. 2015;157:33-8. 
Chapter V

Thomas TS, Wilson WL, Reynolds AB, Oliphant C. Chemical and physical characterization of rabbit sperm acrosome stabilizing factor. Biol. Reprod. 1986;3(5):691-703.

Vicente JS, Viudes-de-Castro MP, Lavara R, Lavara F. Effect of male line on prolificacy from does inseminated with low sperm doses. In Proc: $7^{\text {th }}$ World Rabbit Congress, 47 July 2000, Valencia, Spain. Vol A: pp 273-277.

Vilagran I, Yeste M, Sancho S, Castillo J, Oliva R, Bonet S. Comparative analysis of boar seminal plasma proteome from different freezability ejaculates and identification of Fibronectin 1 as sperm freezability marker. Andrology 2015;3:345-56.

Viudes-de-Castro MP, Marco-Jiménez F, Vicente JS, Navarro E, Lavara R, Mocé E. Sperm kinetic parameters and differences in seminal plasma composition among two rabbit lines. In Proc: $8^{\text {th }}$ Annual Conference of ESDAR. Reprod. Dom. Anim. 2004, 39 (4), 266 (Abstract P13).WARSAW Agricultural University, Polonia.

Viudes-de-Castro MP, Mocé E, Lavara R, Marco-Jiménez F, Vicente JS. Aminopeptidase activity in seminal plasma and effect of dilution rate on rabbit reproductive performance after insemination with an extender supplemented with buserelin acetate. Theriogenology 2014;81:1223-1228.

Vizcaíno JA, Csordas A, del-Toro N, Dianes JA, Griss J, Lavidas I, Mayer G, Pérez-Riverol Y, Reisinger F, Ternent T, Xu QW, Wang R, Hermjakob H. 2016 update of the PRIDE database and related tools. Nucleic Acids Res. 2016;44 (D1):D447-D456.

Wither MJ, Hansen KC, Reisz JA. Mass spectrometry-based bottom-up proteomics: sample preparation, LC-MS/MS analysis, and database query strategies. Curr. Protoc. Protein Sci. 2016;86(16):4.1-16.4.20. 
Yi YJ, Manandhar G, Sutovsky M, Li R, Jonakova V, Oko R, Park CS, Prather RS, Sutovsky P. Ubiquitin C-terminal hydrolase-activity is involved in sperm acrosomal function and anti-polyspermy defense during porcine fertilization. Biol. Reprod. 2007;77:780793.

Zhang H, Wang Y, Zhang J, Wang L, Li Q, Sheng X, Han Y, Yuan Z, Weng Q. Testicular expression of NGF, TrkA and p75 during seasonal spermatogenesis of the wild ground squirrel (Citellus dauricus Brandt). European journal of histochemistry $2015 ; 59: 2522$.

\section{Acknowledgements}

This research was supported in part by the RTA2013-00058-00-00 from INIA, the European Social Fund and the European FEDER Funds. L. Casares-Crespo is supported by a scholarship from Instituto Valenciano de Investigaciones Agrarias (IVIA) and the European Social Fund. P. Fernández-Serrano is supported by Spanish funds from IVIA and Ministerio de Empleo y Seguridad Social (Youth Guarantee Program). The authors are grateful to M. Luz Valero for her excellent technical assistance. 

VIII.CHAPTER VI 



\section{VIII.CHAPTER VI}

\section{Characterization of rabbit (Oryctolagus cuniculus) sperm}

\section{proteins}

L. Casares-Crespo, P. Fernández-Serrano and M.P. Viudes-de-Castro

Centro de Investigación y Tecnología Animal-Instituto Valenciano de Investigaciones Agrarias

(CITA-IVIA), Polígono La Esperanza no 100, 12400 Segorbe, Castellón, Spain 



\section{ABSTRACT}

The present study was conducted to characterise rabbit sperm proteins focusing on the influence of the genetic origin. Six samples were recovered during two months from five males from genotype A (New Zealand White origin) and five from genotype $R$ (California origin). Sperm proteins were extracted and subjected to in-gel digestion nano LC-MS/MS and bioinformatics analysis. The resulting library included 487 identified proteins validated with $\geq 95 \%$ Confidence (unused Score $\geq 1.3$ ). All the identified proteins belonged to Oryctolagus cuniculus taxonomy. These data are available via ProteomeXchange with identifier PXD007989. Only 7 proteins were specifically implicated in reproductive processes according to Gene Ontology annotation. Regarding the comparison of the sperm proteins abundance between genotypes, forty proteins were differentially expressed. Among them, 25 proteins were over-expressed in genotype A, while 15 proteins were over-expressed in genotype R. In conclusion, this study characterizes for the first time rabbit sperm proteins and provides evidence that genotype is related to a specific abundance of spermatozoa proteins. 



\section{INTRODUCTION}

A greater understanding of the proteins involved in reproduction can benefit animal production. New advances in proteomics are having a major impact on our understanding of how spermatozoa acquire their capacity for fertilization (Aitken and Baker, 2008). Sperm proteomics aims at the identification of the proteins that compose the sperm cell and the study of their function (de Mateo et al., 2013). The sperm cell is one of the most highly differentiated cells and is composed of a head with a highly compacted chromatin structure and a large flagellum with midpiece that contains the required machinery for movement and therefore to deliver the paternal genetic and epigenetic content to the oocyte (Codina et al., 2015). By being so highly differentiated, spermatozoa are advantageous cells to study proteomics of specific compartments such as the membrane, which basically is the area of major importance for its role in interacting with the surroundings and the oocyte (Rodríguez-Martínez et al., 2011). The fusion of a sperm and an oocyte is a sophisticated process that must be preceded by suitable changes in the sperm's membrane composition (Nowicka-Bauer et al., 2013). Recent studies of spermatozoa from the proteomic point of view have allowed the identification of different proteins in spermatozoa that are responsible for the regulation of normal/defective sperm functions (Rahman et al., 2013).

While several techniques are available in proteomics, LC-MS based analysis of complex protein/peptide mixtures has turned out to be a mainstream analytical technique for quantitative proteomics (Tuli and Ressom, 2009). Using this method, detailed proteomic data are now available for human (Baker et al., 2007), macaque (Skerget et al., 2013; Kawase et al., 2015), mouse (Baker et al., 2008a), rat (Baker et al., 2008b), bull (Byrne et al., 2012; Ashrafzadeh et al., 2013; Somashekar et al., 2015), stallion 
Chapter VI

(Swegen et al., 2015), fruit fly (Wasbrough et al., 2010), Caenorhabditis elegans (Ma et al., 2014), carp (Dietrich et al., 2016), rainbow trout (Nynca et al., 2014), mussel (Zhang et al., 2015), ram (Pini et al., 2016), honeybee (Zareie et al., 2013), rooster (Labas et al., 2015) and sika deer (Kawase et al., 2015) sperm proteins.

Rabbit (Oryctolagus cuniculus) is an important mammalian species worldwide, being at the same time of commercial interest and a research model animal. European rabbit meat production is approximately 500 thousand tons, corresponding to a $30 \%$ share of world production (Petracci et al., 2009). Besides, rabbits account for the seventh highest number of animals slaughtered per year in the European Union-27, with $347,603 \times 1000$ head in 2014 (FAOSTAT 2014). In a previous work, we identified and quantified rabbit seminal plasma proteins between two different genotypes (CasaresCrespo et al., 2018), concluding the clear effect of genotype in the abundance of certain seminal plasma proteins. However, it is unknown at present whether these differences also exist at sperm proteome level. Therefore, the aim of the present study was to characterise rabbit sperm membrane proteins through nano LC-MS/MS analysis focusing on the influence of the genetic origin.

\section{MATERIALS AND METHODS}

Unless stated otherwise, all chemicals in this study were purchased from Sigma-Aldrich Química S.A (Madrid, Spain). All the experimental procedures used in this study were performed in accordance with Directive 2010/63/EU EEC for animal experiments. 


\section{Localization and animals}

The experiment was carried out with 10 males from two Spanish commercial rabbit genetic lines (genotypes A and R) from March to April 2017. Line A is based on New Zealand White rabbits selected since 1980 by a family index for litter size at weaning over 45 generations. Line R comes from the fusion of two lines, one founded in 1976 with Californian rabbits reared by Valencian farmers and another founded in 1981 with rabbits belonging to specialised paternal lines. All bucks were of proven fertility and subjected to a weekly pattern of ejaculate collection. All animals were housed at the Animal Technology and Research Centre (CITA-IVIA, Segorbe, Castellón, Spain) experimental farm in flat deck indoor cages $(75 \times 50 \times 30 \mathrm{~cm})$, with free access to water and commercial pelleted diets (minimum of $15 \mathrm{~g}$ of crude protein per $\mathrm{kg}$ of dry matter (DM), $15 \mathrm{~g}$ of crude fibre per kg of DM, and $10.2 \mathrm{MJ}$ of digestible energy (DE) per kg of DM). The photoperiod was set to provide $16 \mathrm{~h}$ of light and $8 \mathrm{~h}$ of dark, and the room temperature was regulated to keep temperatures between $14^{\circ} \mathrm{C}$ and $28^{\circ} \mathrm{C}$.

\section{Semen collection, evaluation and sperm samples preparation}

Semen samples were obtained by artificial vagina and collected into a sterile tube. One ejaculate was collected per male and week. Collections were performed on the same day of the week during two months. For each genotype, one pooled sample each week was selected to develop the experiment. A total of 6 pools ( 3 for each genetic line) were analysed. Routine diagnostic semen analyses were performed to assess the initial seminal quality. Only ejaculates exhibiting a white colour and possessing motility rate higher than $70 \%$ were used in the experiment. The volume $(\mathrm{mL})$ of each ejaculate was measured in a graduated conical tube. A $20 \mu \mathrm{L}$ aliquot was diluted 1:50 with $0.25 \%$ 
glutaraldehyde solution to calculate the concentration in a Thoma chamber, the percentage of sperm abnormality and spermatozoa with normal apical ridge (NAR) by phase contrast at a magnification of 400X. The motility characteristics of sperm (percentage of total and progressive motile sperm, evaluated using a computerassisted sperm analysis system) were determined as described by Viudes-de-Castro et al. (2014). Then, ejaculates from the same genotype were pooled each day as a single sample. Each sperm sample was centrifuged at 7,400 x g for $10 \mathrm{~min}$ at $22{ }^{\circ} \mathrm{C}$. The resulting pellets were washed twice by centrifugation at $900 \times \mathrm{g}$ for $10 \mathrm{~min}$ in PBS. Sperm proteins were extracted according to Casares-Crespo et al. (2017) protocol with few modifications. Briefly, sperm pellets were resuspended in $1 \%$ SDS (w/v) in TCG (Tris-citrate-glucose supplemented with a $1 \% \mathrm{v} / \mathrm{v}$ protease inhibitors cocktail) and sonicated on ice 6 times for $5 \mathrm{~s}$ at $30 \%$ amplitude using an Ultrasonic Lab Homogenizer UP $100 \mathrm{H}$ (Hielscher Ultrasonics $\mathrm{GmbH}$ ). After sonication, the solution was kept in ice for $15 \mathrm{~min}$ and centrifuged for $10 \mathrm{~min}$ at $15,000 \mathrm{xg}$ at $4 \stackrel{\circ}{ } \mathrm{C}$. Protein lysates were stored at $-80 \circ \mathrm{C}$ until analysis. Before the proteomic analysis, total protein concentration was quantified in triplicate by the bicinchoninic acid method (BCA) using BSA as standard protein (Smith et al., 1985) and seminal samples were adjusted to $5 \mu \mathrm{g} / \mu \mathrm{L}$ in saline.

\section{In-gel digestion}

The proteomic analysis was performed in the proteomics facility of SCSIE University of Valencia that belongs to ProteoRed, PRB2-ISCIII, supported by grant PT13/0001. Thirty $\mu \mathrm{g}$ of total protein was loaded onto a 1-D SDS PAGE gel but not resolved. The entire sample was cut and analyzed as a single band. Samples were digested with sequencing grade trypsin (Promega) as described elsewhere (Shevchenko et al., 1996). Six hundred 
ng of trypsin in $100 \mu \mathrm{L}$ of ammonium bicarbonate $(A B C)$ solution was used for each sample. The digestion was stopped with trifluoroacetic acid (Fisher Scientific; $1 \%$ final concentration); a double extraction with acetonitrile (ACN) (Fisher Scientific) was done and all the peptide solutions were dried in a rotatory evaporator. The final mixture was resuspended with $30 \mu \mathrm{L}$ of $2 \% \mathrm{ACN} ; 0.1 \%$ trifluoroacetic acid (TFA).

\section{Nano LC-MS/MS analysis}

Three $\mu \mathrm{L}$ of each sample were loaded onto a trap column (nano LC Column, $3 \mu \mathrm{m}$ particles size $\mathrm{C} 18-\mathrm{CL}, 350 \mu \mathrm{m}$ diameter $\mathrm{x} 0.5 \mathrm{~mm}$ long; Eksigent Technologies) and desalted with $0.1 \%$ TFA at $3 \mu \mathrm{L} / \mathrm{min}$ during $5 \mathrm{~min}$. The peptides were then loaded onto an analytical column (LC Column, $3 \mu \mathrm{m}$ particles size $\mathrm{C} 18-\mathrm{CL}, 75 \mu \mathrm{m}$ diameter $\times 12 \mathrm{~cm}$ long, Nikkyo) equilibrated in $5 \%$ acetonitrile (ACN) $0.1 \%$ formic acid (FA). Peptide elution was carried out with a linear gradient of $5 \%$ to $35 \%$ of solvent B in A for $60 \mathrm{~min}$. (A: $0.1 \%$ FA; B: ACN, $0.1 \%$ FA) at a flow rate of $300 \mathrm{~nL} / \mathrm{min}$. Peptides were analysed in a mass spectrometer nano ESIqQTOF (5600 TripleTOF, ABSCIEX).

Eluted peptides were ionized applying $2.8 \mathrm{kV}$ to the spray emitter. The mass spectrometric analysis was carried out in a data-dependent mode. Survey MS1 scans were acquired from $350-1250 \mathrm{~m} / \mathrm{z}$ for $250 \mathrm{~ms}$. The quadrupole resolution was set to 'UNIT' for MS2 experiments, which were acquired from $100-1500 \mathrm{~m} / \mathrm{z}$ for $25 \mathrm{~ms}$ in 'high sensitivity' mode. Following switch criteria were used: charge: $2+$ to 5+; minimum intensity; 70 counts per second (cps). Up to 25 ions were selected for fragmentation after each survey scan. Dynamic exclusion was set to $15 \mathrm{~s}$. The system sensitivity was controlled with $2 \mathrm{fmol}$ of 6 proteins mixture (LC Packings). Samples were injected in a random order. 
Chapter VI

The proteomics data and result-files from the analysis have been deposited to the ProteomeXchange Consortium via the PRIDE (Vizcaíno et al., 2016) partner repository, with the dataset identifier PXD007989 and 10.6019/PXD007989.

\section{Protein identification}

The SCIEX.wiff data-files were processed using ProteinPilotv5.0search engine (AB SCIEX). ProteinPilot default parameters were used to generate peak list directly from 5600 TripleTofwiff files. The Paragon algorithm of ProteinPilot v5.0 was used to search UniProt_mammals' protein database (22/06/2017) with the following parameters: trypsin specificity, cys-alkylation, taxonomy restricted, FDR (False Discovery Rate) calculation and the search effort set to through. For building the spectra library all the files combined were searched with the parameters previously used.

To avoid using the same spectral evidence in more than one protein, the identified proteins are grouped based on MS/MS spectra by the Protein-Pilot Progroup algorithm. A protein group in a Pro Group Report is a set of proteins that share some physical evidence. Unlike sequence alignment analyses where full length theoretical sequences are compared, the formation of protein groups in Pro Group is guided entirely by observed peptides only. Since the observed peptides are actually determined from experimentally acquired spectra, the grouping can be considered to be guided by usage of spectra. Then, unobserved regions of protein sequence play no role in explaining the data. Only peptide and protein identifications with $\geq 95 \%$ Confidence (unused Score $\geq 1.3$ ) were validated. Protein identifications were accepted if they contained at least two identified peptides. 


\section{Label-free protein quantification using Chromatographic Areas}

For quantification, the group file generated by Protein Pilot was used. The ions areas were extracted from the wiff files obtained from LC-MS/MS experiment by Peak View ${ }^{\circledR}$ v1.1. Only peptides assigned with confidence $\geq 95 \%$, among those without modifications or shared by different proteins were extracted. A total of 6 samples were analysed and 487 proteins were quantified.

\section{Bioinformatics analysis}

Gene names of the proteins were obtained from UniProt database by running a Retrieve/ID mapping tool of the protein accession numbers. Gene ontology terms for biological process, molecular function and cellular component were obtained using PANTHER v12.0 (http://www.pantherdb.org/ accessed on 16/08/2017) (Mi et al., 2017). Gene names of all sperm proteins were used to search against the panther database with Homo sapiens as the organism to maximise classifications, and a PANTHER ${ }^{\text {TM }}$ Go Slim analysis was performed for each category.

\section{Statistical analysis}

The quantitative data obtained by PeakView ${ }^{\circledR}$ were analysed by Marker View ${ }^{\circledR}$ V1.3 (AB Sciex). First, areas were normalized by total areas summa, and then a Discriminant Analysis (DA) and a T-Test were done. Proteins were considered differentially expressed between genotypes if the adjusted $p$-value $<0.05$. Mean quantity of proteins were calculated and the fold-changes between the two groups were estimated. 
Chapter VI

\section{RESULTS}

\section{Sperm quality parameters}

Mean values of volume, concentration, percentage of abnormal spermatozoa, total and progressive sperm motility and spermatozoa with normal apical ridge of the samples used in the study are shown in Table 6.1.

Table 6.1. Rabbit sperm characteristics $(n=4)$.

\begin{tabular}{|c|c|}
\hline \multicolumn{2}{|l|}{ Parameters } \\
\hline Concentration ( $\mathrm{N} \times 10^{6}$ spermatozoa/ml) & $447.5 \pm 108.3$ \\
\hline Volume $(\mathrm{mL})$ & $1.5 \pm 0.3$ \\
\hline Sperm abnormality (\%) & $26.2 \pm 3.3$ \\
\hline Acrosome integrity (\%) & $86.5 \pm 2.6$ \\
\hline Total sperm motility (\%) & $83.3 \pm 9.1$ \\
\hline Progressive sperm motility (\%) & $47.7 \pm 5.5$ \\
\hline
\end{tabular}

\section{Rabbit sperm proteome}

The complete spectral library included 487 proteins validated with $\geq 95 \%$ Confidence (unused Score $\geq 1.3$ ) when using at least 2 peptides for identification (Table S6.1). All the identified proteins belonged to Oryctolagus cuniculus taxonomy. These 487 proteins were quantified based on their chromatographic or peak areas (Table S6.2).

The complete rabbit sperm proteome was classified under different categories based on their molecular function, biological process and cellular components (PANTHER analysis). The results are shown in Figure 6.1. For molecular function (Fig. 6.1a), a total of 343 hits were found. The catalytic activity was the predominant function (49\%), followed by binding (26\%) and structural molecule activity (14\%). Regarding biological process (Fig. 6.1b), a total of 669 hits were found. The cellular process (29\%) and the 
metabolic (25\%) were the most abundant categories, but it is worth mentioning that 8 hits (1\%) were classified in the category of reproduction, 4 in the fertilization and the other 4 in gamete generation process. Finally, a total of 336 hits were found for cellular component category (Fig. 6.1c). Cell part (47\%), organelle (27\%), macromolecular complex (15\%) and membrane (6\%) were the most abundant cellular components of the studied proteins.

Figure 6.1. Pie charts showing the distribution of rabbit sperm proteins based on their a) molecular function, b) biological process and c) cellular component, using UniProt KB database in combination with PANTHER.

\section{Molecular function}

a)

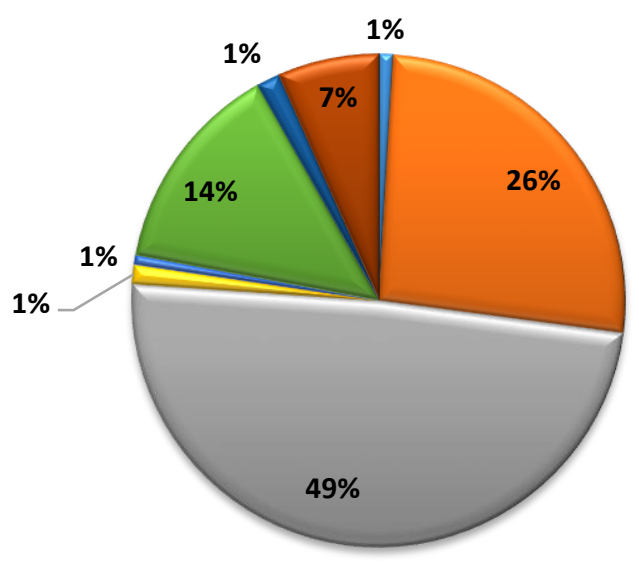

$\square$ Antioxidant Activity

Binding

$\square$ Catalytic Activity

$\square$ Receptor Activity

- Signal Transducer Activity

$\square$ Structural Molecule Activity

- Translation Regulator Activity

- Transporter Activity

b)

\section{Biological process}

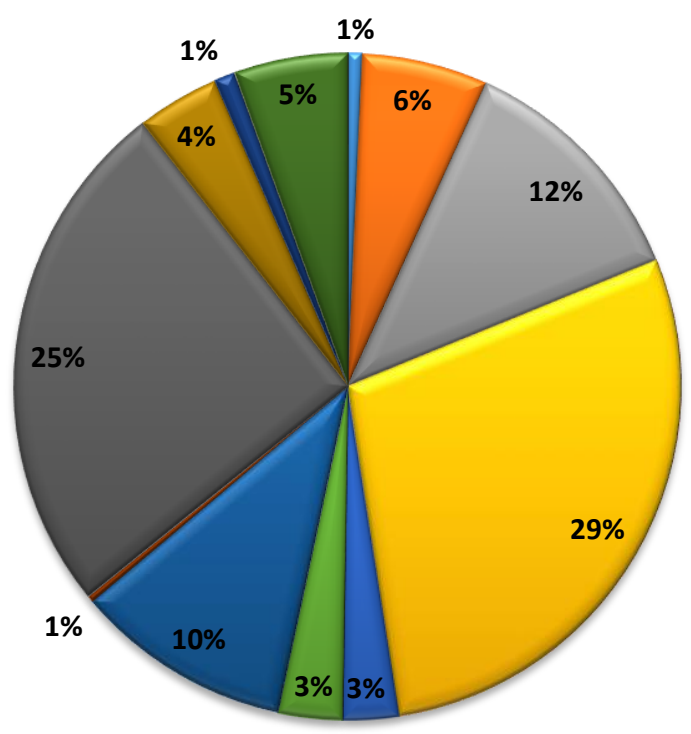

$\square$ Biological Adhesion

$\square$ Biological Regulation

$\square$ Cellular Component Organization

$\square$ Cellular Process

Developmental Process

Immune System Process

Localization

- Locomotion

Metabolic Process

Multicellular Organismal Process

- Reproduction

Response to Stimulus 
c)

\section{Celular component}

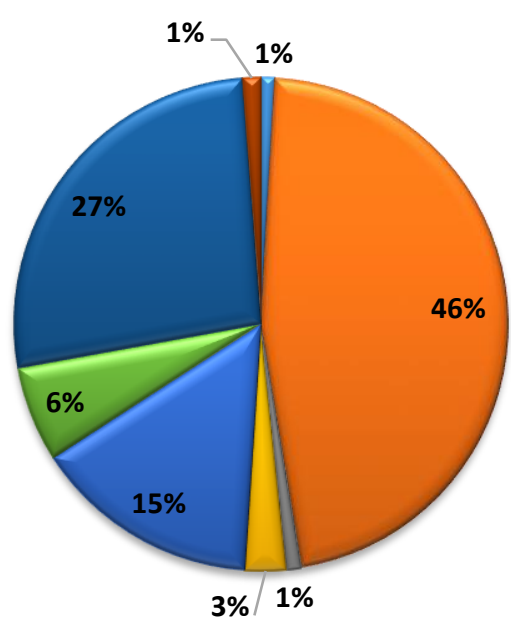

$\square$ Cell Junction

$\square$ Cell Part

$\square$ Extracellular Matrix

$\square$ Extracellular Region

Macromolecular Complex

$\square$ Membrane

口 Organelle

- Synapse

\section{Effect of genetic origin on spermatozoa proteome}

The results of the sperm proteome comparison between both synthetic lines ( $A$ and $R$ ) are shown in Fig. 6.2. Discriminant Analysis (DA) showed a clear separation between samples from different genetic origin, classifying the six sperm samples into two different main clusters corresponding to both genotypes. Given that the proteome between both genotypes presented high variability, a t-test was done. Results showed a total of 40 differentially expressed proteins $(p<0.05)$ between genetic lines. Of the differentially expressed proteins, 25 proteins were over-expressed in genetic line A and 15 proteins over-expressed in line $\mathrm{R}$ (Table 6.2). 
Figure 6.2. Discriminant Analysis (DA) showing the classification of spermatozoa protein samples from genotypes $A$ and $R$, based on relative protein amount.

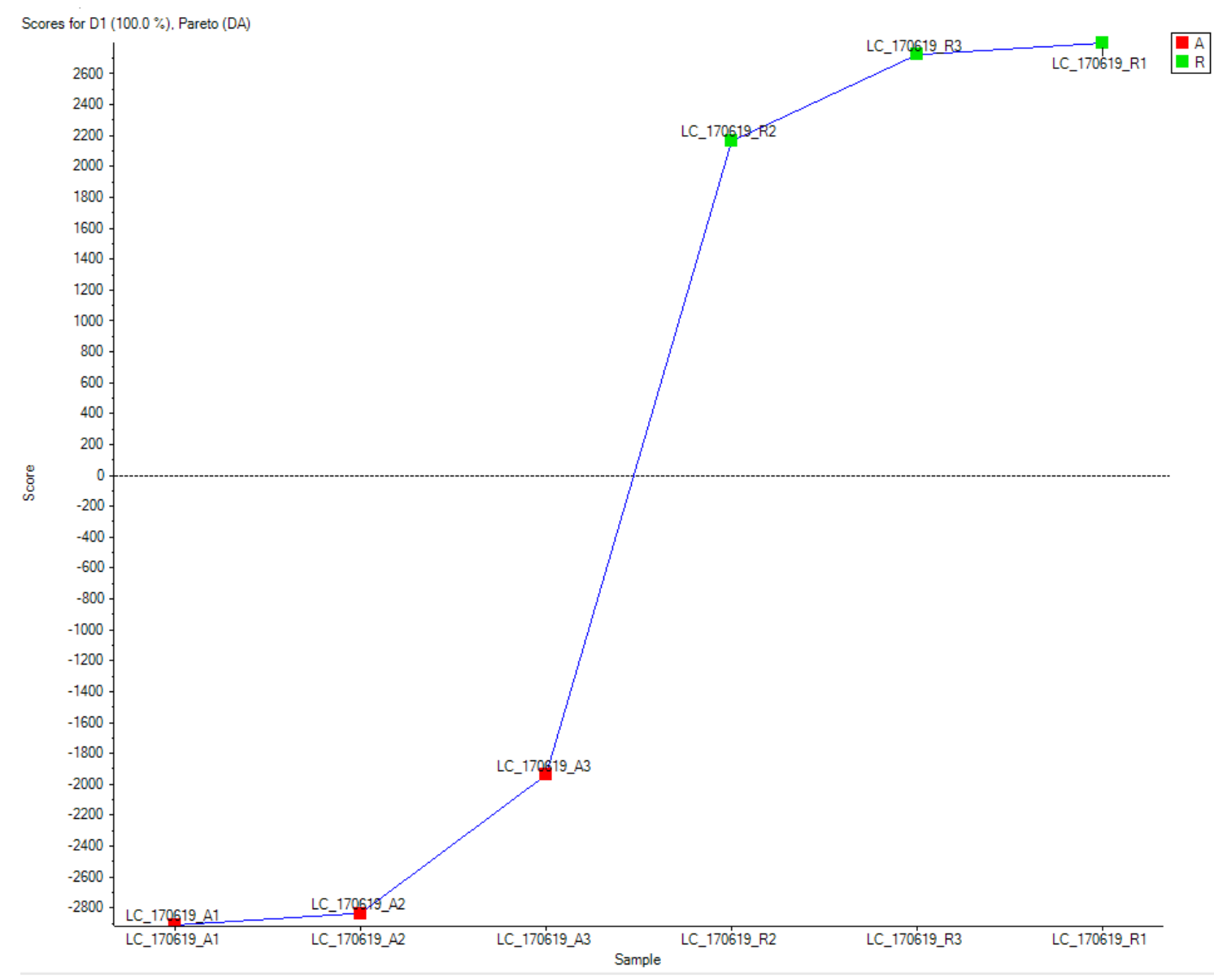


Table 6.2. List of differentially expressed rabbit spermatozoa proteins, included in Oryctolagus cuniculus taxonomy, between genotypes A and R.

\begin{tabular}{|c|c|c|c|c|c|c|}
\hline \multirow{2}{*}{ Gene ID } & \multirow{2}{*}{ Gene name } & \multicolumn{2}{|c|}{ Mean protein amount } & \multirow{2}{*}{$\begin{array}{c}\text { Log } \\
\text { (FoldChange) }\end{array}$} & \multirow{2}{*}{ p-value } & \multirow{2}{*}{ Biological Process } \\
\hline & & Line A & Line $\mathbf{R}$ & & & \\
\hline BASP1 & Brain acid soluble protein 1 & 24770,351 & 88227,532 & -0.552 & 0.00256 & \\
\hline $\begin{array}{c}\text { AOAOG2JH2 } \\
3\end{array}$ & Uncharacterized protein & 14742,829 & 39547,488 & -0.429 & 0.00648 & \\
\hline USP5 & $\begin{array}{l}\text { Ubiquitin carboxyl-terminal } \\
\text { hydrolase } 5\end{array}$ & 19155,099 & 7991,209 & 0.380 & 0.00775 & \\
\hline сСТ8 & $\begin{array}{c}\text { T-complex protein } 1 \text { subunit } \\
\text { theta }\end{array}$ & 289998,762 & 197226,072 & 0.167 & 0.00824 & $\begin{array}{l}\text { Protein folding, protein complex } \\
\text { assembly }\end{array}$ \\
\hline AKR1B1 & Aldose reductase & 2042126,661 & 684791,411 & 0.475 & 0.00885 & \\
\hline PGK2 & Phosphoglycerate kinase 2 & 1853797,274 & 1018697,679 & 0.260 & 0.00950 & Glycolysis \\
\hline FLNB & Filamin-B & 80934,073 & 142157,789 & -0.245 & 0.01146 & $\begin{array}{l}\text { Cellular component } \\
\text { morphogenesis }\end{array}$ \\
\hline PSMA1 & $\begin{array}{c}\text { Proteasome subunit alpha } \\
\text { type-1 }\end{array}$ & 43475,764 & 19905,528 & 0.339 & 0.01313 & \\
\hline SORT1 & Sortilin & 34590,467 & 16905,899 & 0.311 & 0.01353 & $\begin{array}{l}\text { Intracellular protein transport, } \\
\text { lipid metabolic process, lipid }\end{array}$ \\
\hline
\end{tabular}


transport, receptor-mediated

endocytosis

\begin{tabular}{|c|c|c|c|c|c|c|}
\hline ATP11A & $\begin{array}{l}\text { Probable phospholipid- } \\
\text { transporting ATPase IH }\end{array}$ & 7586,766 & 13297,619 & -0.244 & 0.01413 & $\begin{array}{l}\text { Anion transport, catabolic and } \\
\text { cellular process }\end{array}$ \\
\hline S100A8 & Protein S100-A8 & 3106,240 & 42277,814 & -1.134 & 0.01579 & $\begin{array}{l}\text { DNA replication, cell cycle, } \\
\text { macrophage activation }\end{array}$ \\
\hline HSPB1 & Heat shock protein beta-1 & 122006,550 & 270497,552 & -0.346 & 0.01613 & $\begin{array}{l}\text { Protein folding, immune system } \\
\text { process, response to stress }\end{array}$ \\
\hline PRDX1 & Peroxiredoxin-1 & 20463,159 & 48178,975 & -0.372 & 0.01975 & \\
\hline
\end{tabular}

Cell cycle, endocytosis,

$\begin{array}{llllll}\text { ACTC1 Actin, alphacardiac muscle } 1 & 17064660,120 & 19815038,34 & -0.065 & 0.02015 & \text { exocytosis, intracellular protein }\end{array}$

transport

$\begin{array}{llllll}\text { RAB14 } & \text { Ras-relatedprotein Rab-14 } & 11035,514 & 7647,710 & 0.159 & 0.02028\end{array}$

Generation of precursor

metabolites and energy,

ME1

NADP-dependent malic

enzyme
63596,915 24116,024 0.421
0.02191

carbohydrate metabolic process,

cellular amino acid catabolic

process 
Chapter VI

\begin{tabular}{|c|c|c|c|c|c|c|}
\hline G1T1S4 & Uncharacterized protein & 7527,446 & 24318,855 & -0.509 & 0.02279 & \\
\hline MY01C & Unconventional myosin-lc & 9273,656 & 27610,368 & -0.474 & 0.02678 & $\begin{array}{l}\text { Mitosis, cellular component } \\
\text { movement and organization, } \\
\text { cytokinesis, intracellular protein } \\
\text { transport, intracellular signal } \\
\text { transduction }\end{array}$ \\
\hline
\end{tabular}

Cellular process, nuclear

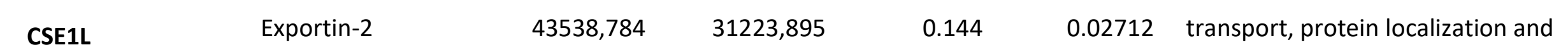

\begin{tabular}{|c|c|c|c|c|c|c|}
\hline ССТ6B & $\begin{array}{c}\text { T-complex protein } 1 \text { subunit } \\
\text { zeta- } 2\end{array}$ & 46030,918 & 30228,978 & 0.183 & 0.02933 & $\begin{array}{l}\text { Protein folding, protein complex } \\
\text { assembly }\end{array}$ \\
\hline ARSA & ATPase ASNA1 & 235936,189 & 118217,646 & 0.300 & 0.02996 & $\begin{array}{l}\text { Ion transport, reponse to toxic } \\
\text { substance }\end{array}$ \\
\hline TCP1 & $\begin{array}{c}\text { T-complex protein } 1 \text { subunit } \\
\text { alpha }\end{array}$ & 280703,715 & 159641,857 & 0.245 & 0.03036 & $\begin{array}{l}\text { Protein folding, protein complex } \\
\text { assembly }\end{array}$ \\
\hline PSMB5 & $\begin{array}{l}\text { Proteasome subunit beta type- } \\
5\end{array}$ & 38988,095 & 20945,469 & 0.270 & 0.03086 & \\
\hline MPST & 3-mercapto pyruvate & 17474,356 & 7178,149 & 0.386 & 0.03302 & Anion transport, immune system \\
\hline
\end{tabular}


sulfurtransferase process, response to toxic

substance

Ferredoxin metabolic process,

nitrogen compound metabolic process, respiratory electron

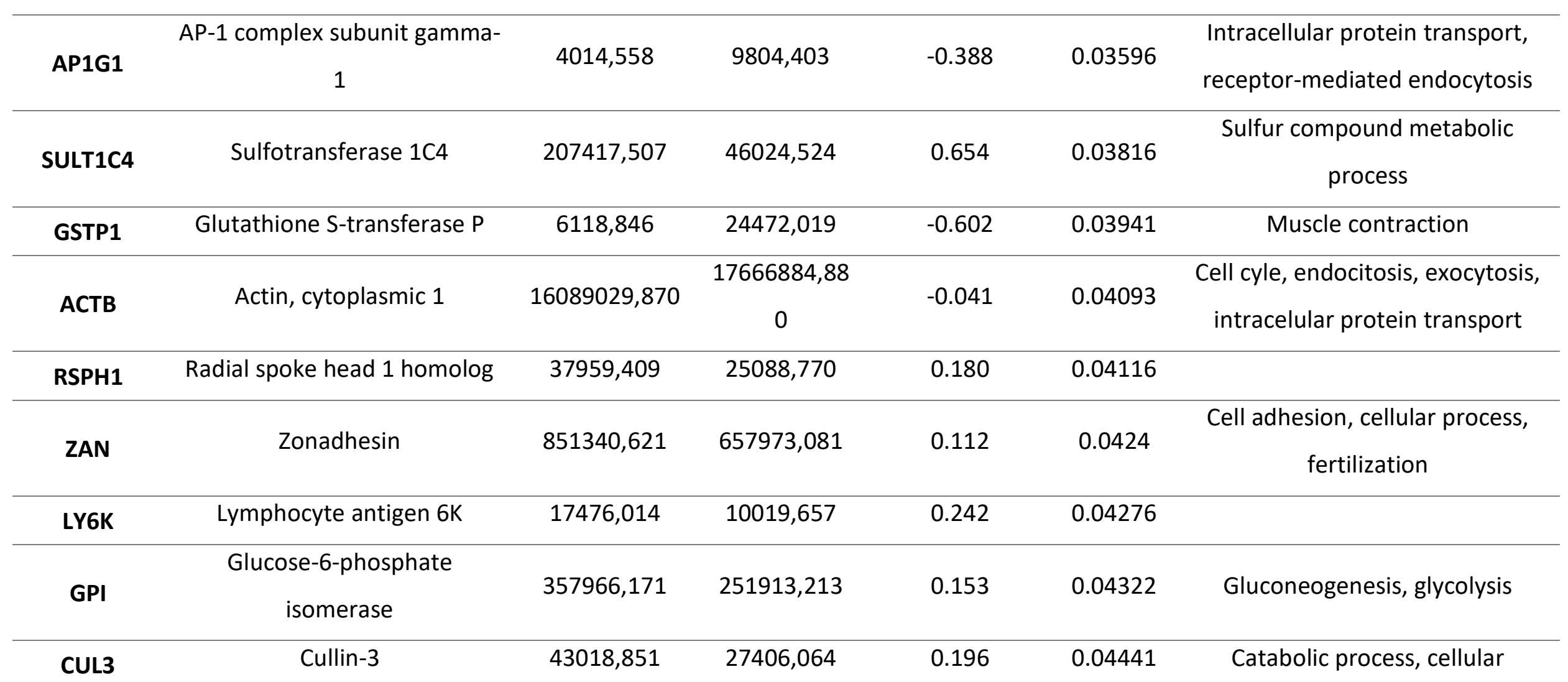


process, cellular protein

modification process, proteolysis

\begin{tabular}{ccccccc}
\hline NT5C3A & Cytosolic 5'-nucleotidase 3A & 23230,678 & 44228,290 & -0.280 & 0.04754 & \\
\hline YWHAE & $14-3-3$ protein epsilon & 187532,157 & 243472,884 & -0.113 & 0.04769 & Regulation of biological process \\
\hline SERPINE2 & Glia-derived nexin & 5889,179 & 1960,672 & 0.478 & 0.04867 & Cellular process, celullar protein \\
\hline \multirow{2}{*}{ KLHL10 } & Kelch-like protein 10 & 14523,219 & 9150,116 & 0.201 & 0.04907 & modification process \\
\hline
\end{tabular}




\section{DISCUSSION}

To the best of our knowledge this is the first study in which rabbit sperm proteins are characterised. As a consequence of the lack of knowledge of rabbit proteomics in comparison with other mammalian species, among the 487 identified proteins 325 were catalogued as uncharacterized proteins. In UniProtKB database the $98 \%$ of the protein sequences have been derived from cDNA or genomic sequencing, thus most of the available protein sequences are reliant on the quantity and quality of DNA or RNA-derived information for that species (Bayram et al., 2016). As a result, studies of the reproductive proteome to date have been limited to model species such as human, mice and fruit fly (Baker et al., 2008a; Wasbrough et al., 2010; Amaral et al., 2014) supported by extensive, high quality genomic information or with dedicated genome projects such as honeybee (Poland et al., 2011) among which rabbit species is not included. In addition, Bayram et al. (2016) studied the species origin of database matches using mammalian proteome database search in UniProtKB and the dominant species were few: human, mouse, rat, sheep and cattle, which account for $87.5 \%$ of the sequences entries. Therefore, the fact that rabbit is a non-model species and lacks a fully annotated genome explains the high number of uncharacterised proteins found in rabbit spermatozoa in the present work. To solve this drawback, all protein accession numbers were translated into gene names in order to analyse the results.

Bioinformatics analysis of rabbit spermatozoa proteome revealed that $49 \%$ of identified proteins were related to catalytic activity and the second dominant group of proteins were assigned to a binding function (26\%). These proportions agree with previous proteomic studies of honeybee and carp spermatozoa (Zareie et al., 2013; Dietrich et al., 2016). Regarding biological process, the cellular process (29\%) was the most abundant category in 
rabbit spermatozoa followed by metabolic process $(25 \%)$, which coincides with honeybee sperm proteins (Zareie et al., 2013). It is also noticeable that only seven of the 487 proteins identified in rabbit spermatozoa are to date recorded in GO as being directly associated with reproductive processes such as fertilization and gamete generation. These proteins related with reproductive processes are the following: acrosin-binding protein (ACRBP), zonadhesin (ZAN), sperm equatorial segment protein 1 (SPESP1), serine protease inhibitor Kazal type 8 (SPINK8), dual specificity testis-specific protein kinase 2 (TESK2), dynein heavy chain 9 (DNAL1) and four and a half LIM domains protein 1 (FHL1). It is surprising that so few spermatozoa proteins are found in the category of reproduction and that many of the proteins studied in this work have not been assigned a specific role in GO. In previous studies in boar and in rabbit seminal plasma, authors encountered the same situation (Pérez-Patiño et al., 2016; Casares-Crespo et al., 2018). Despite of this, we are sure that the identified sperm proteins are directly or indirectly related to reproduction processes. Finally, GO analysis revealed that the majority of rabbit spermatozoa proteins were extracted from cell parts, organelles and membranes.

Among the twenty-five more abundant proteins in genotype $A$, we found proteins related to different biological functions such as: protein folding, glycolysis, protein transport, metabolism, ion transport and fertilization.

СCT8, ССТ3, ССТ2 and ССT6B are chaperones that contain the TCP1 complex and whose function is to assist the folding of other proteins such as tubulin and actin upon ATP hydrolysis [http://www.uniprot.org/uniprot/G1SHZ8]. In addition, arylsulfatase A protein (ARSA) has been localized in the acrosomal region of human spermatozoa and it is known to increase its surface expression significantly during capacitation (Redgrove et al., 2012). These proteins have been related to sperm zona pellucida interaction role in mouse and 
human spermatozoa by several authors (Dun et al., 2011; Redgrove et al., 2011, 2012). On the other hand, zonadhesin protein' (ZAN) role is to mediate species-specific zona pellucida adhesion (Tardif et al., 2010) and has been localized in the anterior acrosome of rabbit spermatozoa (Lea et al., 2001). In a previous work (Casares-Crespo et al., 2018), zonadhesin, was also found more abundant in seminal plasma of rabbit A genotype compared to genotype R. Furthermore, other proteins over-expressed in genotype A are: cullin 3 (CUL3), which has been recently found to have an important role in the human sperm flagellum (Jumeau et al., 2017), phosphoglycerate kinase 2 (PGK2), that has shown to be essential for sperm motility and male infertility in mice (Danshina et al., 2010) and SERPINE2, which may play a role as a decapacitation factor (Lu et al., 2011). All of these findings, especially the increased amount of these proteins observed in genotype $A$ in comparison with genotype $R$ could explain in part the enhanced fertility and prolificacy previously described in genotype A (Lavara et al., 2005; Safaa et al., 2008).

On the other hand, among the fifteen more abundant proteins in genotype $R$, we found proteins related to different biological functions such as: antioxidant activity, binding, catalytic activity, transporter activity and structural molecule activity.

For instance, the protein HSPB1 belongs to a superfamily of mammalian small stress proteins and its function has been suggested to be related to the cytoskeleton (Fontaine et al., 2003). Just like ACTB protein, which is an actin involved in cell motility and cytokinesis (Zeng et al., 2014). On the other hand, peroxiredoxins such as PRDX1 are highly sensible to oxidative stress proteins which are involved in the antioxidant protection of the mammalian spermatozoa (Liu and O'Flaherty, 2017). Finally, BASP1 protein, which has been located in rat mature spermatozoa, may be participating in biochemical processes through the activation of calcium (Mosevitsky et al., 2012). 
In summary, the present study characterises for the first time rabbit sperm proteins and generates a publicly accessible database of rabbit sperm proteome, which still remains poorly understood. In addition, our data provide evidence that genotype has a huge impact on protein abundance in rabbit sperm. The present work together with the previous study of rabbit seminal plasma lead to the complete characterization of rabbit semen. Further studies are needed in order to elucidate the reproductive role of these identified proteins and the different evolution of these genotypes that gives rise to the intraspecies variation found.

\section{REFERENCES}

Aitken RJ, Baker MA. The role of proteomics in understanding sperm cell biology. Int. J. Androl. 2008;31:295-302.

Amaral A, Castillo J, Ramalho-Santos J, Oliva R. The combined human sperm proteome: cellular pathways and implications for basic and clinical science. Hum. Reprod. Update $2014 ; 20: 40-62$

Ashrafzadeh A, Nathan S, Karsani SA. Comparative analysis of Mafriwal (Bos Taurus $\times$ Bos indicus) and Kedah Kelantan (Bos indicus) sperm proteome identifies sperm proteins potentially responsible for higher fertility in a tropical climate. International Journal of Molecular Sciences 2013;14:15860-77.

Baker MA, Hetherington L, Reeves GM, Aitken RJ. The mouse sperm proteome characterized via IPG strip prefractionation and LC-MS/MS identification. Proteomics 2008a;8:1720-30.

Baker MA, Hetherington L, Reeves G, Müller J, Aitken RJ. The rat sperm proteome characterized via IPG strip prefractionation and LC-MS/MS identification. Proteomics $2008 b ; 8: 2312-21$. 
Baker MA, Reeves G, Hetherington L, Müller J, Baur I, Aitken RJ. Identification of gene products present in Triton X-100 soluble and insoluble fractions of human spermatozoa lysates using LC-MS/MS analysis. Proteomics Clinical Applications 2007;1:524-32.

Bayram HL, Claydon AJ, Brownridge PJ, Hurst JL, Mileham A, Stockley P, Beynon RJ, Hammond DE. Cross-species proteomics in analysis of mammalian sperm proteins. Journal of proteomics 2016;135:38-50.

Byrne K, Leahy T, McCulloch R, Colgrave ML, Holland MK. Comprehensive mapping of the bull sperm surface proteome. Proteomics 2012;12:3559-79.

Casares-Crespo L, Fernández-Serrano P, Vicente JS, Marco-Jiménez F, Viudes-de-Castro MP. Rabbit seminal plasma proteome: the importance of the genetic origin. Anim. Reprod. Sci. $2018 ; 189-30-42$.

Casares-Crespo L, Fernández-Serrano P, Viudes-de-Castro MP. Effect of the detergent used on the resulting rabbit sperm membrane proteome. XVII Jornadas Sobre Producción Animal, Zaragoza, España. 2017:383-385.

Codina M, Estanyol JM, Fidalgo MJ, Ballescà JL, Oliva R. Advances in sperm proteomics: bestpractise methodology and clinical potential. Expert review of proteomics 2015;12:255-77.

Danshina PV, Geyer CB, Dai Q, Goulding EH, Willis WD, Kitto GB, McCarrey JR, Eddy EM, O'Brien DA. Phosphoglycerate kinase 2 (PGK2) is essential for sperm function and male fertility in mice. Biol. Reprod. 2010;82:136-45.

de Mateo S, Estanyol JM, Oliva R. Methods for the analysis of the sperm proteome. Spermatogenesis: Methods and Protocols 2013:411-22.

Dietrich MA, Dietrich GJ, Mostek A, Ciereszko A. Motility of carp spermatozoa is associated with profound changes in the sperm proteome. Journal of proteomics 2016;138:124-35. 
Dun MD, Smith ND, Baker MA, Lin M, Aitken RJ, Nixon B. The chaperonin containing TCP1 complex (CCT/TRiC) is involved in mediating sperm-oocyte interaction. J. Biol. Chem. 2011;286:36875-87.

FAOSTAT. 2014. Food and Agriculture Organization of the United Nations. Available at http://www.fao.org/faostat/en/\#data/QL. Last access July 2017.

Fontaine JM, Rest JS, Welsh MJ, Benndorf R. The sperm outer dense fiber protein is the $10^{\text {th }}$ member of the superfamily of mammalian small stress proteins. Cell Stress \& Chaperones 2003;8:62-9.

Jumeau F, Chalmel F, Fernandez-Gomez FJ, Carpentier C, Obriot H, Tardivel M, Caillet-Boudin ML, Rigot JM, Rives N, Buee L, Sergeant N, Mitchell V. Defining the human sperm microtubulome: an integrated genomics approach. Biol. Reprod. 2017;96:93-106.

Kawase O, Cao S, Xuan X. Sperm membrane proteome in wild Japanese macaque (Macaca fuscata) and Sika deer (Cervus nippon). Theriogenology 2015;83:95-102.

Labas V, Grasseau I, Cahier K, Gargaros A, Harichaux G, Teixeira-Gomes A, Alves S, Bourin M, Gérard N, Blesbois E. Qualitative and quantitative peptidomic and proteomic approaches to phenotyping chicken semen. Journal of proteomics 2015;112:313-35.

Lavara R, Mocé E, Lavara F, Viudes-de-Castro MP, Vicente JS. Do parameters of seminal quality correlate with the results of on-farm inseminations in rabbits? Theriogenology 2005;64:1130-41.

Lea IA, Sivashanmugam P, O'Rand MG. Zonadhesin: characterization, localization, and zona pellucidabinding. Biol. Reprod. 2001;65:1691-700.

Liu Y, O'Flaherty C. In vivo oxidative stress alters thiol redox status of peroxiredoxin 1 and 6 and impairs rat sperm quality. Asian J. Androl. 2017;19:73-9. 
Lu C, Lee RK, Hwu Y, Chu S, Chen Y, Chang W, Lin S, Li S. SERPINE2, a serine protease inhibitor extensively expressed in adult male mouse reproductive tissues, may serve as a murine sperm decapacitation factor. Biol. Reprod. 2011;84:514-25.

Ma X, Zhu Y, Li C, Xue P, Zhao Y, Chen S, Yang F, Miao L. Characterisation of Caenorhabditis elegans sperm transcriptome and proteome. BMC Genomics 2014;15:168.

Mi H, Huang X, Muruganujan A, Tang H, Mills C, Kang D, Thomas PD. PANTHER version 11: expanded annotation data from Gene Ontology and Reactome pathways, and data analysis tool enhancements. Nucleic Acids Res. 2017;45:D183-9.

Mosevitsky MI, Snigirevskaya ES, Komissarchik YY. Immunoelectron microscopic study of BASP1 and MARCKS location in the early and late rat spermatids. Acta Histochem. 2012;114:237-43.

Nowicka-Bauer K, Kurpisz M. Current knowledge of the human sperm proteome. Expert review of proteomics 2013;10:591-605.

Nynca J, Arnold GJ, Fröhlich T, Otte K, Ciereszko A. Proteomic identification of rainbow trout sperm proteins. Proteomics 2014;14:1569-73.

Pérez-Patiño C, Barranco I, Parrilla I, Valero ML, Martínez EA, Rodríguez-Martínez H, Roca J. Characterization of theporcine seminal plasma proteomecomparing ejaculate portions. Journal of Proteomics 2016;142:15-23.

Petracci M, Bianchi M, Cavani C. Development of rabbit meat products fortified with $n-3$ polyunsaturated fatty acids. Nutrients 2009;1:111-8.

Pini T, Leahy T, Soleilhavoup C, Tsikis G, Labas V, Combes-Soia L, Harichaux G, Rickard JP, Druart X, de Graaf SP. Proteomic Investigation of Ram Spermatozoa and the Proteins Conferred by Seminal Plasma. Journal of Proteome Research 2016;15:3700-11. 
Poland V, Eubel H, King M, Solheim C, Harvey Millar A, Baer B. Stored sperm differs from ejaculated sperm by proteome alterations associated with energy metabolism in the honeybee Apis mellifera. Mol. Ecol. 2011;20:2643-54.

Safaa HM, Vicente JS, Lavara R, Viudes-de-Castro MP. Semen evaluation of two selected lines of rabbit bucks. World Rabbit Science 2008;16:141-148.

Shevchenko A, Jensen ON, Podtelejnikov AV, Sagliocco F, Wilm M, Vorm O, Mortensen P, Shevchenko A, Boucherie H, Mann M. Linking genome and proteome by mass spectrometry: large-scale identification of yeast proteins from two dimensional gels. Proc. Natl. Acad. Sci. 1996;93(25):14440-5.

Skerget S, Rosenow M, Polpitiya A, Petritis K, Dorus S, Karr TL. The Rhesus macaque (Macaca mulatta) sperm proteome. Mol. Cell. Proteomics 2013;12:3052-67.

Smith PK, Krohn RI, Hermanson GT, Mallia AK, Gartner FH, Provenzano MD, Fujimoto EK, Goeke NM, Olson BJ, Klenk DC. Measurement of protein using bicinchoninic acid. Anal Biochem 1985;150:76-85.

Somashekar L, Selvaraju S, Parthipan S, Ravindra JP. Profiling of sperm proteins and association of sperm PDC-109 with bull fertility. Systems biology in reproductive medicine 2015;61:376-87.

Swegen A, Curry BJ, Gibb Z, Lambourne SR, Smith ND, Aitken RJ. Investigation of the stallion sperm proteome by mass spectrometry. Reproduction 2015;149:235-44.

Rahman MS, Lee JS, Kwon WS, Pang MG. Sperm proteomics: road to male fertility and contraception. Int. J. Endocrinol. 2013:360986.

Redgrove KA, Anderson AL, Dun MD, McLaughlin EA, O'Bryan MK, Aitken RJ, Nixon B. Involvement of multimeric protein complexes in mediating the capacitation-dependent 
binding of human spermatozoa to homologous zonae pellucidae. Dev. Biol. 2011;356:46074.

Redgrove KA, Nixon B, Baker MA, Hetherington L, Baker G, Liu DY, Aitken RJ. The molecular chaperone HSPA2 plays a key role in regulating the expression of sperm surface receptors that mediate sperm-egg recognition. PLOS ONE 2012;7(11):e50851.

Rodríguez-Martínez H, Kvist U, Ernerudh J, Sanz L, Calvete JJ. Seminal plasma proteins: what role do they play? American Journal of Reproductive Immunology 2011;66:11-22.

Tardif S, Wilson MD, Wagner R, Hunt P, Gertsenstein M, Nagy A, Lobe C, Koop BF, Hardy DM. Zonadhesin is essential for species specificity of sperm adhesion to the egg zona pellucida. J. Biol. Chem. 2010;285:24863-70.

Tuli L, Ressom HW. LC-MS Based Detection of Differential Protein Expression. J. Proteomics Bioinform 2009;2:416-38.

Viudes-de-Castro MP, Mocé E, Lavara R, Marco-Jiménez F, Vicente JS. Aminopeptidase activity in seminal plasma and effect of dilution rate on rabbit reproductive performance after insemination with an extender supplemented with buserelin acetate. Theriogenology 2014;81(9):1223-8.

Vizcaíno JA, Csordas A, del-Toro N, Dianes JA, Griss J, Lavidas I, Mayer G, Perez-Riverol Y, Reisinger F, Ternent T, Xu QW, Wang R, Hermjakob H. 2016 update of the PRIDE database and related tools. Nucleic Acids Res. 2016;44(D1): D447-D456.

Wasbrough ER, Dorus S, Hester S, Howard-Murkin J, Lilley K, Wilkin E, Polpitiya A, Petritis K, Karr TL. The Drosophila melanogaster sperm proteome-II (DmSP-II). Journal of proteomics 2010;73:2171-85. 
Zareie R, Eubel H, Millar AH, Baer B. Long-term survival of high quality sperm: insights into the sperm proteome of the honeybee Apis mellifera. Journal of Proteome Research $2013 ; 12: 5180-8$

Zeng C, He L, Peng W, Ding L, Tang K, Fang D, Zhang Y. Selection of optimal reference genes for quantitative RT-PCR studies of boar spermatozoa cryopreservation. Cryobiology 2014;68:113-21.

Zhang Y, Mu H, Lau SC, Zhang Z, Qiu J. Sperm proteome of Mytilus gallo provincialis: Insights into the evolution of fertilization proteins in marine mussels. Proteomics $2015 ; 15: 4175-9$.

\section{Acknowledgements}

This research was supported in part by the RTA2013-00058-00-00 from INIA, the European Social Fund and the European FEDER Funds. L. Casares-Crespo is supported by a scholarship from InstitutoValenciano de InvestigacionesAgrarias (IVIA) and the European Social Fund. P. Fernández-Serrano is supported by Spanish funds from IVIA and Ministerio de Empleo y Seguridad Social (Youth Guarantee Program). 
IX.GENERAL DISCUSSION 



\section{IX.GENERAL DISCUSSION}

\section{DEVELOPMENT OF NEW ARTIFICIAL INSEMINATION EXTENDERS SUPPLEMENTED WITH GnRH ANALOGUES}

The use of artificial insemination (Al) in rabbit farms has become a common practice in European countries, being currently used in more than $80 \%$ of the Spanish and EU rabbit farms (Quintela et al., 2009). Al offers the same benefits for rabbit breeding as in other species in the control of genetic diversity, rapid upgrading of stock, establishment of pregnancies in females which refuse to mate, and avoidance of the spread of diseases (Morrell, 1995). In addition, using Al, an ejaculate from one male can be used to inseminate a large number of females and conception rates after Al with fresh semen are equivalent to or even better than those obtained by natural mating (Daniel and Renard, 2010; Kitajima, 2009).

The rabbit (Oryctolagus cuniculus) is considered a reflexively ovulating species in which ovulation is induced by sensory stimulation associated with mating. In this species, a short mating bout including ejaculation induces genital somatosensory cues that contribute to the activation on $\mathrm{GnRH}$ neurons and the consequential generation of a preovulatory LH surge from the pituitary gland (Rebollar et al., 2012). Therefore, when using $\mathrm{Al}$, the administration of a $\mathrm{GnRH}$ analogue is mandatory to induce doe ovulation due to the lack of nervous stimuli evoked by the male. This treatment requires an intramuscular injection, which can result in stress to the animal and additional work for the farm operators (Dal Bosco et al., 2011). Moreover, in most rabbit farms, GnRH injection is usually performed by the farmer, with a certain risk of misuse, and 


\section{General Discussion}

increasing the time needed for the artificial insemination of each doe (Quintela et al., 2009). Recent studies have investigated the possibility of ovulation induction in rabbits by vaginal absorption after supplementation of the seminal dose with different GnRH synthetic analogues (Gogol, 2016a, 2016b; Dal Bosco et al., 2014; Quintela et al., 2004, 2009; Ondruška et al., 2008; Vicente et al., 2008, 2011; Viudes-de-Castro et al., 2007, 2014). There are clear breeding advantages of intravaginal administration of GnRH analogue (noninvasive route, less treatment distress, labor for the farmers, and operating time), but unfortunately, to achieve fertility results similar to those with GnRH intramuscular injection, the intravaginally hormone concentration should be much higher than the amount administered intramuscularly (Viudes-de-Castro et al., 2014). The absorption of $\mathrm{GnRH}$ by vaginal mucosa is influenced by several factors. The main barrier is mucosal permeation, but another factor that limits the bioavailability of $\mathrm{GnRH}$ analogue is the proteolytic activity found in the seminal plasma as well as in the female vagina. For this reason, in order to obtain fertility rates comparable with those obtained with the usual intramuscular injection, the intravaginal GnRH dose has to be at least 15-fold higher (Quintela et al., 2009), becoming a potential health risk for farmers. Various approaches to improve protein delivery by vaginal route include: use of enzyme inhibitors, absorption enhancers, mucoadhesive polymers and/or novel carrier systems such as nanoparticles.

With this background, the first three chapters of this thesis aimed to develop new Al extenders supplemented with different substances in order to increase the bioavailability of the $\mathrm{GnRH}$ analogue without affecting ovulation induction or the reproductive performance. 
In the first chapter, our hypothesis was that if we used protease inhibitors in Al extenders, part of the enzyme activity that degrades the $\mathrm{GnRH}$ analogue would be inhibited and therefore, the bioavailability of the hormone would be higher. Therefore, the objective was to evaluate the effect of the inclusion of protease inhibitors in semen extender on in vitro rabbit semen quality parameters and on reproductive performance after Al. The results showed that rabbit semen extender supplementation with a protease inhibitors cocktail affected neither semen quality (motility, viability, acrosome integrity) nor fertility rate, but affected the prolificacy rate by decreasing the total number of kits born per litter ( 9.3 vs. 8.2, positive control and AMIS group, respectively).

Several studies have tested the effect of different protease inhibitors on mammal sperm in vitro quality. For instance, leupeptin had no effect in rabbit sperm motility (de Lamirande et al., 1986). In pig, spermatozoa incubated in medium with AEBSF were less motile after $6 \mathrm{~h}$ of incubation, yet progressive motility, VAP, VSL, acrosome status and mitochondrial potential remained unaltered (Beek et al., 2015). These results are consistent with ours, as seminal quality parameters were similar between control and protease inhibitors group after $2 \mathrm{~h}$ of incubation.

The fact that the inclusion of protease inhibitors in semen extender affected the prolificacy rate, having this group one kit less per delivery, could be explained because proteases play an important role during mammalian fertilization. Seminal plasma composition is designed to assure the successful fertilization of the oocyte and is characterized by a high abundance of proteins which play important roles in sperm survival and are involved in various events such as epididymal sperm maturation, sperm capacitation, sperm membrane stabilization, modulation of the uterine immune 


\section{General Discussion}

response, sperm transport in the female genital tract, gamete interaction and fusion and even pregnancy establishment (Okabe et al., 1993; Topfer-Petersen et al., 1998; Gwathmey et al., 2006; Rodríguez-Martínez et al., 2011; Laflamme et al., 2013). The abundance of proteases and protease inhibitors in seminal plasma show the importance of this system in this body fluid (Pilch et al., 2006). In human, for example, the $60 \%$ of the seminal plasma proteome has enzymatic activity. Therefore, the inhibition of a wide variety of proteases with the cocktail used, could have negatively affected this process. In addition, the part of the fecundation process affected by protease inhibitors seems to be species-specific. For instance, in guinea pig, the incubation of sperm with leupeptin inhibited the completion of the acrosomal reaction, but bestatin had no effect (Flaherty et al., 1993). In bovine sperm, the use of trypsin and chymotrypsin inhibitors, but not metalloproteases, were effective in inhibiting the acrosomal reaction process and in addition, sperm incubation with these proteases did not reveal statistically differences in the sperm zona pellucida binding capacity in relation to control sperm (Deppe et al., 2008). In pig, the effect of AEBSF on in vitro fertilization and polyspermy rates were a decreased by at least $50 \%$ (Beek et al., 2015). In mouse and human, the use of specific serine proteases inhibitors decreases the fertilization rate (Fraser, 1982; Llanos et al., 1993). Finally, studies in sea urchin provide evidence for the involvement of metalloproteases in membrane fusion during the acrosome reaction (Farach et al., 1987).

Therefore, considering the results of our first study, we conclude that as a consequence of the addition of a wide variety of protease inhibitors in the rabbit semen extender, prolificacy rate was negatively affected. For this reason, we conducted a second experiment in which we only inhibited the aminopeptidase 
activity (APN), because in a previous work by Viudes-de-Castro et al. (2014), authors observed that the bioavailability of buserelin acetate when added to the seminal dose appeared to be determined by the activity of the existing seminal plasma aminopeptidases. We supplemented Al extenders with bestatin and EDTA as aminopeptidase inhibitors (AMIs) and we evaluated their effect on in vitro rabbit semen traits (motility, acrosome status and viability) and on in vivo reproductive performance (fertility and prolificacy) after Al. Moreover, a secondary objective of this second work was to study the effect of AMls on $\beta$-nerve growth factor ( $\beta$-NGF) protein's protection from enzyme degradation. $\beta$-NGF is a highly conserved protein of about $14 \mathrm{kDa}$, capable of inducing ovulation when administered intramuscularly to other reflex ovulators species such as alpaca, llama and camel females (Kershaw-Young et al., 2012; Silva et al., 2015; Berland et al., 2016; Adams et al., 2016; El Allali et al., 2017). $\beta$-NGF has been identified in rabbit seminal plasma (Casares-Crespo et al., 2016a, 2018b) and its mRNA in adult rabbit's prostate, seminal gland and testis (García-García et al., 2017). However, in rabbit species, $\beta$-NGF protein or seminal plasma intramuscular administration to rabbit does does not provoke ovulation (Silva et al., 2011; García-García et al., 2017). Although the function of the $\beta$-NGF protein in rabbit reproduction remains unknown, we thought that it was interesting to find out if AMIs were able to protect it while protecting GnRH analogue.

The results of this second study showed that the addition of bestatin and EDTA in the rabbit semen extender had neither effect on semen quality nor on the fertilizing capacity of spermatozoa. In agreement with our results, the addition of bestatin to guinea pig sperm had no effect on membrane fusion (Flaherty et al., 1993) and the incubation of bovine sperm with EDTA did not affect the acrosome reaction (Deppe et 
al., 2008). Thus, the fecundation process damaged in the first work by protease inhibition (Casares-Crespo et al., 2016b) seemed not to be affected by bestatin and EDTA, showing a similar prolificacy rate between groups with or without AMIs (10.12 vs. 10.15, respectively). On the other hand, the presence of AMls improves the bioavailability of $\beta$-NGF in semen up to $12 \mathrm{~h}$ of storage. As a consequence, the possible ovulation/fertilization modulator role of $\beta$-NGF was assured over this time by the presence of bestatin and EDTA in the extender, being able to protect $\beta$-NGF from enzyme degradation.

Given that it was demonstrated that $\mathrm{Al}$ extender supplementation with aminopeptidase inhibitors (AMIs) such as bestatin and EDTA did not affect rabbit seminal quality nor reproductive performance (Casares-Crespo et al., 2018a), but inhibited part of the seminal plasma aminopeptidase activity, the third study aimed to evaluate the in vivo effect of a $20 \%$ reduction of hormone concentration in extenders supplemented with AMIs. Besides, we have managed to develop chitosan (CS)-dextran sulfate (DS) nanoparticles containing buserelin acetate (Fernández-Serrano et al., 2017). In this previous work, we achieved a hormone entrapment efficiency of $40-50 \%$ and showed that these nanoparticles did not affect rabbit seminal quality parameters and, in addition, significantly increased the acrosome integrity of spermatozoa. Therefore, in this third chapter we tested the effect of a $20 \%$ reduction of hormone concentration in extenders supplemented with AMIs and with the GnRH analogue free or entrapped in CS-DS nanoparticles on rabbit reproductive performance.

According to our results, when the buserelin acetate was non encapsulated, although the extenders were supplemented with bestatin and EDTA, the utilization of $4 \mu \mathrm{g}$ hormone/doe significantly reduced fertility rate compared to group with $5 \mu \mathrm{g}$ 
hormone/doe ( 0.70 vs. 0.85 , respectively). This fact shows that even though part of the enzymatic activity of seminal plasma is inhibited, the bioavailability of $\mathrm{GnRH}$ is not enough to allow a $20 \%$ reduction in the concentration of hormone in the extender without compromising fertility. Maybe it is possible that we are working with a limiting hormone concentration ( $5 \mu \mathrm{g} / \mathrm{doe}$ ) and even a small hormone reduction could affect fertility. In this sense, there is only another work in which a GnRH analogue concentration lower than $5 \mu \mathrm{g} /$ doe has been used in rabbit ovulation induction, and the results were the same as ours, with fertility rate significantly lower and similar prolificacy rate (2.5 $\mathrm{gg} /$ doe $\mathrm{GnRH}$-Lecirelinum in seminal dose) (Ondruška et al., 2008). On the other hand, when buserelin acetate was encapsulated in CS-DS nanoparticles, no differences in fertility and prolificacy were observed between $4 \mu \mathrm{g}$ hormone/doe or $5 \mu \mathrm{g}$ hormone/doe, showing similar values than C5 group $(0.85,0.82$ and 0.85 , respectively). Thus, with the use of nanoparticles, the $\mathrm{GnRH}$ analogue seems to be protected against degradation and a $20 \%$ hormone reduction does not affect fertility. In resemblance with our results, Trapani et al. (2010) employed CS based nanoparticles in oral administration of a small peptide (glutathione), and they achieved to protect the drug from the enzymatic gastric degradation and induce permeabilization of the intestinal epithelia. In addition, Han et al. (1995), in an in vitro study in rabbit, observed that the permeability of the vaginal membrane to GnRH increased twice when EDTA was used, suggesting that enzyme inhibition effect of EDTA resulted in substantial enhancement of vaginal absorption. Therefore, the enzyme inhibitor role of bestatin and EDTA besides the absorption enhancement effect of EDTA and the protection role of chitosan and dextran sulfate nanoparticles and their mucoadhesive function, all together, could explain the fertility rate improvement of Q4 group 
General Discussion

compared to C4 group. In conclusion, the CS-DS nanoparticles prepared by coacervation process as carrier for buserelin acetate overcome some of the limitations associated with the vaginal application of the hormone in rabbit artificial insemination and allow to reduce the concentration of hormone used in an extender supplemented with bestatin and EDTA without affecting the fertility and prolificacy of rabbit females. Therefore, nano encapsulation seems to be a promising system to protect the GnRH analogue in order to decrease the hormone concentration in rabbit artificial insemination extenders.

\section{PROTEOMIC CHARACTERIZATION OF RABBIT SEMEN}

The use proteomics in order to identify and quantify the semen proteins of commercially relevant species has provided a lot of new information lately. In species such as boar, stallion, bull, ram, rooster, turkey, salmon, carp and trout, seminal plasma and/or sperm proteins have been studied with this method (Dietrich et al., 2014a, 2014b; Gombar et al., 2017; Marzoni et al., 2013; Novak et al., 2010; Nynca et al., 2014a, 2014b; Pérez-Patiño et al., 2016; Pini et al., 2016; Rego et al., 2016; Slowinska et al., 2017). Although rabbit is an important mammalian species worldwide, being at the same time of commercial interest and a research model animal and European rabbit meat production corresponds to a $30 \%$ share of world production (Petracci et al., 2009), a limited number of studies have performed an analysis of rabbit seminal plasma or sperm proteins (Arruda-Alencar et al., 2012; Davis and Davis, 1983; de Lamirande et al., 1983; Lavon, 1972; Minelli et al., 2001; Okabe et al., 1993; Thomas et al., 1986; Viudes-de-Castro et al., 2004). Because rabbit seminal plasma and sperm proteome remained unsolved, we decided to study them, becoming the second 
objective of the present thesis. In chapter four, five and six, we looked into rabbit semen proteins from two different methodology approaches (1D polyacrylamide gel versus LC-MS/MS). Moreover, we compared the protein abundance between rabbit genetic breeds $A$ and $R$ and between seasons.

In the fourth and fifth chapters, seminal plasma of rabbits from genotype A (maternal line) and $\mathrm{R}$ (paternal line) was collected during a natural year and was subjected to polyacrylamide gel electrophoresis (SDS-PAGE) or to nano LC-MS/MS, respectively. In the fourth chapter, a traditional 1D polyacrylamide gel was done; being able to identify only the major proteins visible after Coomassie Colloidal Blue staining and obtaining the differentially expressed bands by the relative quantity of the protein bands through scanning and analysing the gel with 1D software. When using this approach, seven protein bands were significantly different between genetic lines and among these, three protein bands were significantly different between seasons. The differentially expressed proteins were: FAM115E-like (220, 113 and 59 kDa), ectonucleoside triphosphate diphosphohydrolase 3 isoform X2 (72 kDa), annexin A5 (32 kDa), lipocalin allergen Ory c 4 precursor (19 kDa), and hemoglobin subunit zetalike (13 kDa) between genetic lines and FAM115E-like (113 kDa), hemoglobin subunit zeta-like (13 kDa) and $\beta$-Nerve growth factor (12 kDa) between seasons. However, with the same samples and through nano LC-MS/MS technique, we were able to identify and quantify 402 proteins and twenty-three proteins were significantly different between genotypes. Therefore, the fact that in the fifth study a more accurate technique such as LC-MS/MS was used in order to identified the differentially expressed proteins, could explain the differences found between previous (CasaresCrespo et al., 2016a; Safaa et al., 2008; Viudes-de-Castro et al., 2004) and current 


\section{General Discussion}

results. Indeed, the exceptional sensitivity and resolving power of today's mass spectrometers allow for the detection of proteins and peptides at low femtomole quantities (Wither et al., 2016).

Bioinformatics analysis of rabbit SP proteome revealed that $50 \%$ of identified proteins were related to catalytic activity and the second dominant group of proteins were assigned to a binding function (27\%). These proportions agree with previous proteomic studies of human, ram, carp and boar seminal plasma (Dietrich et al., 2014; PérezPatiño et al., 2016; Pilch and Mann, 2006; Souza et al., 2012). Inside the category of catalytic activity, the aminopeptidase B protein is included. This enzyme has an important role in rabbit $\mathrm{Al}$ because it is responsible for degrading the $\mathrm{GnRH}$ analogue when it is added to the seminal dose to induce doe ovulation. In previous works, we have demonstrated that aminopeptidase activity in rabbit seminal plasma reduces the bioavailability of the GnRH analogue (Viudes-de-Castro et al., 2014) and new extenders with aminopeptidase inhibitors are being developed (Casares-Crespo et al., 2016b, 2017). Regarding biological process, the metabolic (28\%) was the most abundant category in rabbit SP, which coincides with human, carp and boar SP proteins (Dietrich et al., 2014; Pérez-Patiño et al., 2016; Souza et al., 2012). It is also noticeable that only 6 of the 402 proteins identified in rabbit SP are to date recorded in GO as being directly associated with reproductive processes. Similar results were found in boar SP, where only 20 of the 374 proteins identified were annotated as related to reproduction (Pérez-Patiño et al., 2016).

Additionally, our results clearly indicate that SP proteins abundance in rabbit seems to be related to a specific genotype, which in several previous studies have demonstrate differences in sperm quality, fertility and prolificacy (Safaa et al., 2008; Vicente et al., 
2000). As stated, we identified a higher abundance of 11 proteins in genotype $A$ seminal plasma, while another 12 proteins were more abundant in genotype $\mathrm{R}$ seminal plasma.

Among the over-expressed proteins in genotype A, we find uteroglobin and zonadhesin. Uteroglobin has been identified in rabbit seminal plasma and in rabbit uterus secretions (Kirchner and Schroer, 1976; Müller, 1983) and zonadhesin in spermatozoa (Lea et al., 2001), but their role remains unknown to date. While uteroglobin, also present in the prostate, may be responsible for suppressing sperm antigenicity in the rabbit (Mukherjee et al., 1983), zonadhesin is located exclusively in the anterior acrosome and may be one of the proteins that anchors the acrosomal shroud to the zona pellucida (http://www.uniprot.org/uniprot/P57999), thereby allowing the spermatozoa to continue penetration and fertilization to proceed spermatozoa (Lea et al., 2001). In addition, we also observed a greater amount of ectonucleoside triphosphate diphosphohydrolase 3 protein, which agrees with the results of chapter four and has been related with acrosome alteration when it concentration decreased (Taha et al., 2011). All of these findings, especially the increased amount of these proteins observed in genotype A in comparison with genotype $\mathrm{R}$ could explain in part the better acrosome integrity of spermatozoa and the enhanced fertility and prolificacy previously described in genotype A (Lavara et al., 2005; Safaa et al., 2008).

Other over-expressed proteins in line A such as plastin 1 and ubiquitin carboxylterminal hydrolase have been found related to spermatogenesis in other species (Kwon et al., 2004; Li et al., 2015). Plastins are a family of actin binding proteins known to cross-link actin microfilaments in mammalian cells, creating actin microfilament 


\section{General Discussion}

bundles necessary to confer cell polarity and cell shape (Li et al., 2016). There are three types of plastins: plastin 1, 2, and 3. All three are expressed in Sertoli cells and plastin 1 and 2 in testes germ cells (Li et al., 2016). Plastin protein has been found in boar seminal plasma exosomes (Piehl et al., 2013) and in rat testis (Li et al., 2015). Plastin 1 deficient mice were fertile and displayed a normal reproductive rate (Grimm-Gunter et al., 2009), what suggests an additional role of plastin far from the fertility process. On the other hand, ubiquitin carboxyl-terminal hydrolase isozyme 3 may function in the meiotic differentiation of spermatocytes into spermatids (Kwon et al., 2004).

Seminal plasma contains antioxidants that are free radical scavengers that protect sperm cells against oxidative stress (Bousnane et al., 2017). For instance, catalase serves to protect cells from the toxics effects of hydrogen peroxide (http://www.uniprot.org/uniprot/Q64405). In bulls, the levels of catalase in seminal plasma have been found higher in high-fertile males than in subfertile bulls (Kumar et al., 2016). In addition, the supplementation of post-thawed rooster semen with 100 $\mu \mathrm{g} / \mathrm{mL}$ of catalase has beneficial effects on semen quality (Amini et al., 2015). In line with this, the protein named elongation factor 4 is required for accurate and efficient

protein synthesis under certain stress conditions (http://www.uniprot.org/uniprot/Q5KWZ3). Therefore, the over-expression of catalase and elongation factor 4 proteins in seminal plasma of genotype A supports the better recovery and performance of thawed semen from genotype A compared to $R$ (Mocé et al., 2003).

The rest of the over-expressed proteins in line A were enzymes such as carbonic anhydrase 2 , which has been found to have a role in the regulation of bicarbonate concentration in horse seminal plasma and accordingly regulate seminal plasma $\mathrm{pH}$ 
(Asari et al., 1996), aspartate aminotransferase (AST) which is an important regulator of glutamate (http://www.uniprot.org/uniprot/P33097) and peptidyl-prolyl cis-trans isomerise which keeps in an inactive conformation of the TGF-beta type I serine/threonine kinase receptor, preventing TGF-beta receptor activation in absence of ligand (http://www.uniprot.org/uniprot/P26883).

On the other hand, genotype R presents higher abundance in several proteins related with reproductive function such as insulin-like growth factor-binding protein 7 which is important for correct spermatogenesis (Belardin et al., 2016) and polyubiquitin C which is involved in sperm-zona pellucida interactions and antipolyspermy defense in pig (Yi et al., 2007). Besides, genotype $\mathrm{R}$ seminal plasma has more quantity of Heat shock $70 \mathrm{kDa}$ 1-like protein. Heat shock proteins (70 and $90 \mathrm{kDa}$ ) are chaperones implicated in a wide variety of cellular processes, including protection of the proteome from stress, folding and transport of newly synthesized polypeptides, activation of proteolysis of misfolded proteins and the formation and dissociation of protein complexes (http://www.uniprot.org/uniprot/POCB32). In several species like porcine, ovine and bovine, heat shock $70 \mathrm{kDa}$ protein 8 was found to prolong the survival of spermatozoa at body temperature in vitro (Elliot et al., 2009; Lloyd et al., 2009). The greater abundance of this heat shock protein in line $\mathrm{R}$ could explain the better performance of line R spermatozoon when they are stored in vitro during several days (unpublished work, ICTA, 2016). Based on the foregoing, our results provide evidence that genotype has a clear effect on seminal plasma protein abundance.

Regarding the effect of the season on the rabbit seminal plasma proteome, in chapter four we showed a season effect on the abundance of three proteins (FAM115E-like, haemoglobin subunit zetalike and nerve growth factor), but again, these relative 


\section{General Discussion}

quantity protein differences were obtained with a less resolute proteomic technique. In the current work, results showed that there are slight protein differences between seasons but it does not exist a clear pattern of protein variation throughout the year for both genotypes. This lack of variation could be explained by the controlled environmental conditions used in our study where animals were kept under $16 \mathrm{~h}$ light/ $8 \mathrm{~h}$ dark and maintained between $14{ }^{\circ} \mathrm{C}$ and $28^{\circ} \mathrm{C}$ using cooling and heating systems over the year.

Finally, we determined the variation of $\beta$-NGF in rabbit seminal plasma. $\beta$-NGF quantity in other reflexively ovulating species such as llama represents $30 \%$ of the total seminal plasma protein content (20 mg/ejaculate) (Berland et al., 2016), whereas in rabbit seminal plasma it only represents about $1.4 \%$, independently of the genotype. Kershaw-Young et al. (2012) observed that intramuscular administration of llama seminal plasma (equivalent to $<1 / 4$ of an ejaculate) resulted in high rate ovulation induction of females ( $94 \%$ compared to $0 \%$ when saline was administered). Interestingly, in other works, the intramuscular administration of rabbit seminal plasma induced ovulation in llamas, but not in rabbits (Silva et al., 2011). The low proportion of $\beta$-NGF protein in rabbit seminal plasma and the fact that this protein is also present in a relatively low proportion in the seminal plasma of the majority of spontaneous ovulators (Druart et al., 2013), could lead us to think that $\beta$-NGF may have different function. In cows, Stewart et al. (2018) have shown that $\beta$-NGF from bull seminal plasma enhances corpus luteum formation and conceptus development. On the other hand, Maranesi et al. (2015) hypothetized that the role of $\beta$-NGF protein in rabbit seminal plasma may be related to the modulation of the ovulation/fertilization events. Moreover, $\beta$-NGF concentration in rabbit seminal plasma decreased in winter 
compared to the other seasons, which agrees with the results in chapter four. This may be related to the natural reluctance of rabbits to breed in the early winter and it accords with Zhang et al. (2015) findings in wild ground squirrels, which showed that the production of NGF in testes was decreased during the non-breeding season and increased in the breeding season.

Finally, in chapter six we characterised rabbit sperm proteome by nano LC-MS/MS focusing on the influence of the genetic origin. Bioinformatics analysis of rabbit spermatozoa proteome revealed that $49 \%$ of identified proteins were related to catalytic activity and the second dominant group of proteins were assigned to a binding function (26\%). These proportions agree with previous proteomic studies of honeybee and carp spermatozoa (Zareie et al., 2013; Dietrich et al., 2016). Regarding biological process, the cellular process $(29 \%)$ was the most abundant category in rabbit spermatozoa followed by metabolic process $(25 \%)$, which coincides with honeybee sperm proteins (Zareie et al., 2013). It is also noticeable that only seven of the 487 proteins identified in rabbit spermatozoa are to date recorded in GO as being directly associated with reproductive processes such as fertilization and gamete generation. These proteins related with reproductive processes are the following: acrosin-binding protein (ACRBP), zonadhesin (ZAN), sperm equatorial segment protein 1 (SPESP1), serine protease inhibitor Kazal type 8 (SPINK8), dual specificity testis-specific protein kinase 2 (TESK2), dynein heavy chain 9 (DNAL1) and four and a half LIM domains protein 1 (FHL1). It is surprising that so few spermatozoa proteins are found in the category of reproduction and that many of the proteins studied in this work have not been assigned a specific role in GO. In previous studies in boar and in rabbit seminal plasma, authors encountered the same situation (Pérez-Patiño et al., 2016; Casares- 


\section{General Discussion}

Crespo et al., 2018b). Despite of this, we are sure that the identified sperm proteins are directly or indirectly related to reproduction processes. Finally, GO analysis revealed that the majority of rabbit spermatozoa proteins were extracted from cell parts, organelles and membranes.

Among the twenty-five more abundant proteins in genotype $A$, we found proteins related to different biological functions such as: protein folding, glycolysis, protein transport, metabolism, ion transport and fertilization.

ССT8, ССТ3, ССТ2 and ССТ6B are chaperones that contain the TCP1 complex and whose function is to assist the folding of other proteins such as tubulin and actin upon ATP hydrolysis [http://www.uniprot.org/uniprot/G1SHZ8]. In addition, arylsulfatase A protein (ARSA) has been localized in the acrosomal region of human spermatozoa and it is known to increase its surface expression significantly during capacitation (Redgrove et al., 2012). These proteins have been related to sperm zona pellucida interaction role in mouse and human spermatozoa by several authors (Dun et al., 2011; Redgrove et al., 2011, 2012). On the other hand, zonadhesin protein' (ZAN) role is to mediate species-specific zona pellucida adhesion (Tardif et al., 2010) and has been localized in the anterior acrosome of rabbit spermatozoa (Lea et al., 2001). In the previous chapter (Casares-Crespo et al., 2018b), zonadhesin, was also found more abundant in seminal plasma of rabbit A genotype compared to genotype $\mathrm{R}$. Furthermore, other proteins over-expressed in genotype A are: cullin 3 (CUL3), which has been recently found to have an important role in the human sperm flagellum (Jumeau et al., 2017), phosphoglycerate kinase 2 (PGK2), that has shown to be essential for sperm motility and male infertility in mice (Danshina et al., 2010) and SERPINE2, which may play a role as a decapacitation factor (Lu et al., 2011). All of 
these findings, especially the increased amount of these proteins observed in genotype A in comparison with genotype $\mathrm{R}$ could explain in part the enhanced fertility and prolificacy previously described in genotype A (Lavara et al., 2005; Safaa et al., 2008).

On the other hand, among the fifteen more abundant proteins in genotype $R$, we found proteins related to different biological functions such as: antioxidant activity, binding, catalytic activity, transporter activity and structural molecule activity.

For instance, the protein HSPB1 belongs to a superfamily of mammalian small stress proteins and its function has been suggested to be related to the cytoskeleton (Fontaine et al., 2003). Just like ACTB protein, which is an actin involved in cell motility and cytokinesis (Zeng et al., 2014). On the other hand, peroxiredoxins such as PRDX1 are highly sensible to oxidative stress proteins which are involved in the antioxidant protection of the mammalian spermatozoa (Liu and O'Flaherty, 2017). Finally, BASP1 protein, which has been located in rat mature spermatozoa, may be participating in biochemical processes through the activation of calcium (Mosevitsky et al., 2012).

In summary, this last chapter characterises for the first time rabbit sperm proteins and generates a publicly accessible database of rabbit sperm proteome, which still remains poorly understood. In addition, our data provide evidence that genotype has a huge impact on protein abundance in rabbit sperm. The last three chapters of this thesis lead to the complete characterization of rabbit semen. Further studies are needed in order to elucidate the reproductive role of these identified proteins and the different evolution of these genotypes that gives rise to the intraspecies variation found. 


\section{LITERATURE CITED}

Adams GP, Ratto MH, Silva ME, Carrasco RA. Ovulation-inducing factor (OIF/NGF) in seminal plasma: a review and update. Reprod. Domest. Anim. 2016;51(2):4-17.

Amini MR, Kohram H, Zare-Shahaneh A, Zhandi M, Sharideh H, Nabi MM. The effects of different levels of catalase and superoxide dismutase in modified Beltsville extender on rooster post-thawed sperm quality. Cryobiology 2015;70:226-32.

Arruda-Alencar JM, Viana-Neto AM, Souza CEA, Martins JAM, Moreno FB, Moreira $\mathrm{ACM}$, et al. Major proteins of the seminal plasma of New Zealand white rabbits and association with semen criteria. $10^{\text {th }}$ World Rabbit Congress. Sharm El-Sheikh, Egypt: World Rabbit Science Association; 2012. pp 395-9.

Asari M, Sasaki K, Miura K, Ichihara N, Nishita T. Immunohistolocalization of the carbonic anhydrase isoenzymes (CA-I, CA-II, and CA-III) in the reproductive tract of male horses. Am. J. Vet. Res 1996;57:439-43.

Beek J, Maes D, Nauwynck H, Piepers S, Van Soom A. A critical assessment of the effect of serine protease inhibitors on porcine fertilization and quality parameters of porcine spermatozoa in vitro. Reprod. Biol. 2015;15(1):9-19.

Belardin LB, Del Giudice PT, Camargo M, Intasqui P, Antoniassi MP, Bertolla RP, Cedenho AP. Alterations in the proliferative/apoptotic equilibrium in semen of adolescents with varicocele. J. Assist. Reprod. Genet. 2016;33:1657-64.

Berland MA, Ulloa-Leal C, Barria M, Wright H, Dissen GA, Silva ME, Ojeda SR, Ratto MH. Seminal plasma induces ovulation in llamas in the absence of a copulatory stimulus: role of nerve growth factor as an ovulation-inducing factor. Endocrinology 2016;157:3224-32. 
Bousnane NEH, May S, Yahia M, Abu Alhaija AA. Association of CAT-262C/T with the concentration of catalase in seminal plasma and the risk for male infertility in Algeria. Systems Biology in Reproductive Medicine 2017:1-8.

Casares-Crespo L, Fernández-Serrano P, Vicente JS, Marco-Jiménez F, Viudes-de-Castro MP. Rabbit seminal plasma proteome: the importance of the genetic origin. Anim. Reprod. Sci. 2018b;189-30-42.

Casares-Crespo L, Fernández-Serrano P, Vicente JS, Mocé E, Castellini C, Stabile AM, Viudes-de-Castro MP. Insemination extender supplementation with bestatin and EDTA has no effect on rabbit reproductive performance. Theriogenology 2018a;105:61-65.

Casares-Crespo L, Talaván AM, Viudes-de-Castro MP. Can the genetic origin affect rabbit seminal plasma protein profile along the year? Reprod. Domest. Anim. 2016a;51(2):294-300.

Casares-Crespo L, Vicente JS, Talaván AM, Viudes-de-Castro MP. Does the inclusion of protease inhibitors in the insemination extender affect rabbit reproductive performance? Theriogenology 2016b;85(5):928-32.

Dal Bosco A, Rebollar PG, Boiti C, Zerani M, Castellini C. Ovulation induction in rabbit does: current knowledge and perspectives. Anim. Reprod. Sci. 2011;129:106-17.

Dal Bosco A, Cardinali R, Brecchia G, Rebollar PG, Fatnassi M, Millan P, Mattioli S, Castellini C. Induction of ovulation in rabbits by adding Lecirelin to the seminal dose: in vitro and in vivo effects of different excipients. Anim. Reprod. Sci. 2014;150:44-9.

Daniel N, Renard JP. Artificial insemination in rabbits. Cold Spring Harbor Protocols 2010(1):pdb.prot5358. 
Danshina PV, Geyer CB, Dai Q, Goulding EH, Willis WD, Kitto GB, McCarrey JR, Eddy EM, O'Brien DA. Phosphoglycerate kinase 2 (PGK2) is essential for sperm function and male fertility in mice. Biol. Reprod. 2010;82:136-45.

Davis BK, Davis NV. Binding by glycoproteins of seminal plasma membrane vesicles accelerates decapacitation in rabbit spermatozoa. Biochim. Biophys. 1983;727:7076.

de Lamirande E, Gagnon C. Effects of protease inhibitors and substrates on motility of mammalian spermatozoa. J. Cell Biol. 1986;102(4):1378-83.

Deppe $M$, Morales $\mathrm{P}$, Sanchez R. Effect of protease inhibitors on the acrosome reaction and sperm-zona pellucida binding in bovine sperm. Reprod. Domest. Anim. 2008;43(6):713-9.

Dietrich MA, Arnold GJ, Nynca J, Frohlich T, Otte K, Ciereszko A. Characterization of carp seminal plasma proteome in relation to blood plasma. Journal of Proteomics 2014a;98:218-232.

Dietrich MA, Arnold GJ, Frohlich T, Ciereszko A. In-depth proteomic analysis of carp (Cyprinus carpio L) spermatozoa. Comp. Biochem. Physio.I Part. D Genomics Proteomics 2014b;12:10-5.

Dietrich MA, Dietrich GJ, Mostek A, Ciereszko A. Motility of carp spermatozoa is associated with profound changes in the sperm proteome. Journal of proteomics 2016;138:124-35.

Dun MD, Smith ND, Baker MA, Lin M, Aitken RJ, Nixon B. The chaperonin containing TCP1 complex (CCT/TRiC) is involved in mediating sperm-oocyte interaction. J. Biol. Chem. 2011;286:36875-87. 
Druart X, Rickard JP, Mactier S, Kohnke PL, Kershaw-Young CM, Bathgate R, Gibb Z, Crossett B, Tsikis G, Labas V, Harichaux G, Grupen CG, de Graaf SP. Proteomic characterization and cross species comparison of mammalian seminal plasma. Journal of Proteomics 2013;91:13-22.

El Allali K, El Bousmaki N, Ainani H, Simonneaux V. Effect of the camelid's seminal plasma ovulation-inducing factor/beta-NGF: a kisspeptin target hypothesis. Front. Vet. Sci. 2017;4:99.

Elliott RM, Lloyd RE, Fazeli A, Sostaric E, Georgiou AS, Satake N, Watson PF, Holt WV. Effects of HSPA8, an evolutionarily conserved oviductal protein, on boar and bull spermatozoa. Reproduction 2009;137:191-203.

Farach HA Jr, Mundy DI, Strittmatter WJ, Lennarz WJ. Evidence for the involvement of metalloendoproteases in the acrosome reaction in sea urchin sperm. J. Biol. Chem. $1987 ; 262(12): 5483-7$.

Fernández-Serrano P, Casares-Crespo L, Viudes-de-Castro MP. Chitosan-dextran sulfate nanoparticles for $\mathrm{GnRH}$ release in rabbit insemination extenders. Reprod. Domest. Anim. 2017;52(4):72-74.

Flaherty SP, Swann NJ. Proteases are not involved in the membrane fusion events of the lysolecithin-mediated guinea pig sperm acrosome reaction. J. Cell. Sci. 1993;104:163-72.

Fontaine JM, Rest JS, Welsh MJ, Benndorf R. The sperm outer dense fiber protein is the $10^{\text {th }}$ member of the superfamily of mammalian small stress proteins. Cell Stress Chaperones 2003;8:62-9. 


\section{General Discussion}

Fraser LR. P-aminobenzamidine, an acrosin inhibitor, inhibits mouse sperm penetration of the zona pellucida but not the acrosome reaction. J. Reprod. Fertil. $1982 ; 65(1): 185-94$.

García-García RM, Masdeu MdM, Sánchez Rodríguez A, Millán P, Arias-Álvarez M, Sakr OG, Bautista JM, Castellini C, Lorenzo PL, Rebollar PG. $\beta$-nerve growth factor identification in male rabbit genital tract and seminal plasma and its role in ovulation induction in rabbit does. Italian Journal of Animal Science 2017:1-12.

Gogol P. Reproductive performance of rabbit does artificially inseminated with semen supplemented with GnRH analogue [des-Gly10, D-Ala6]-LH-RH ethylamide. Pol. J. Vet. Sci. 2016a;19:659-61.

Gogol P. Effect of goserelin and leuprolide added to the semen on reproductive performance in rabbits - Short communication. Acta Vet. Hung. 2016b;64:116-9.

Gombar R, Pitcher TE, Lewis JA, Auld J, Vacratsis PO. Proteomic characterization of seminal plasma from alternative reproductive tactics of Chinook salmon (Oncorhynchus tswatchysha). Journal of Proteomics 2017;157:1-9.

Grimm-Gunter EM, Revenu C, Ramos S, Hurbain I, Smyth N, Ferrary E, Louvard D, Robine S, Rivero F. Plastin 1 binds to keratin and is required for terminal web assembly in the intestinal epithelium. Mol. Biol. Cell. 2009;20:2549-62.

Gwathmey TM, Ignotz GG, Mueller JL, Manjunath P, Suarez SS. Bovine seminal plasma proteins PDC-109, BSP-A3, and BSP-30-kDa share functional roles in storing sperm in the oviduct. Biol. Reprod. 2006;75:501-7.

Han K, Park JS, Chung YB, Jeong NJ, Park HB, Robinson JR. Development of luteinizing hormone releasing hormone (LHRH) delivery systems for vaginal mucosal route. Archives of Pharmacal Research 1995;18(5):325-331. 
Jumeau F, Chalmel F, Fernandez-Gomez FJ, Carpentier C, Obriot H, Tardivel M, CailletBoudin ML, Rigot JM, Rives N, Buee L, Sergeant N, Mitchell V. Defining the human sperm microtubulome: an integrated genomics approach. Biol. Reprod. 2017;96:93106.

Kershaw-Young CM, Druart X, Vaughan J, Maxwell WM. Beta-Nerve growth factor is a major component of alpaca seminal plasma and induces ovulation in female alpacas. Reprod. Fertil. Dev. 2012;24:1093-7.

Kirchner C, Schroer HG. Uterine secretion-like proteins in the seminal plasma of the rabbit. J. Reprod. Fertil. 1976;47:325-30.

Kitajima S. Improvement of rabbit production. In: Houdebine LM., Fan J. (eds) Rabbit Biotechnology. Springer, Dordrecht. 2009:3-12.

Kumar P, Saini M, Kumar D, Bharadwaj A, Yadav P. Estimation of endogenous levels of osteopontin, total antioxidant capacity and malondialdehyde in seminal plasma: Application for fertility assessment in buffalo (Bubalus bubalis) bulls. Reproduction in Domestic Animals 2017;52(2):221-226.

Kwon J, Wang YL, Setsuie R, Sekiguchi S, Sakurai M, Sato Y, Lee WW, Ishii Y, Kyuwa S, Noda M, Wada K, Yoshikawa Y. Developmental regulation of ubiquitin C-terminal hydrolase isozyme expression during spermatogenesis in mice. Biol. Reprod. 2004;71:515-21.

Laflamme BA, Wolfne MF. Identification and function of proteolysis regulators in seminal fluid. Molecular Reproduction and Development 2013;80:80-101.

Lavara R, Moce E, Lavara F, Viudes de Castro MP, Vicente JS. Do parameters of seminal quality correlate with the results of on-farm inseminations in rabbits?. Theriogenology 2005;64:1130-41. 
Lavon U. Characterization of boar, bull, ram and rabbit seminal plasma proteins by gel disc electrophoresis and isoelectric focusing on polyacrylamide. J. Reprod. Fertil. 1972;31(1):29-37.

Llanos M, Vigil P, Salgado AM, Morales P. Inhibition of the acrosome reaction by trypsin inhibitors and prevention of penetration of spermatozoa through the human zona pellucida. J. Reprod. Fertil. 1993;97(1):173-8.

Lea IA, Sivashanmugam P, O'Rand MG. Zonadhesin: characterization, localization, and zona pellucida binding. Biol. Reprod. 2001;65:1691-700.

Li N, Mruk DD, Wong CK, Lee WM, Han D, Cheng CY. Actin-bundling protein plastin 3 is a regulator of ectoplasmic specialization dynamics during spermatogenesis in the rat testis. FASEB J. 2015;29:3788-805.

Li N, Wong CK, Cheng CY. Plastins regulate ectoplasmic specialization via its actin bundling activity on microfilaments in the rat testis. Asian J. Androl. 2016;18:71622.

Liu Y, O'Flaherty C. In vivo oxidative stress alters thiol redox status of peroxiredoxin 1 and 6 and impairs rat sperm quality. Asian J. Androl. 2017;19:73-9.

Lu C, Lee RK, Hwu Y, Chu S, Chen Y, Chang W, Lin S, Li S. SERPINE2, a serine protease inhibitor extensively expressed in adult male mouse reproductive tissues, may serve as a murine sperm decapacitation factor. Biol. Reprod. 2011;84:514-25.

Lloyd RE, Elliott RM, Fazeli A, Watson PF, Holt WV. Effects of oviductal proteins, including heat shock $70 \mathrm{kDa}$ protein 8 , on survival of ram spermatozoa over $48 \mathrm{~h}$ in vitro. Reprod. Fertil. Dev. 2009;21:408-18.

Maranesi M, Zerani M, Leonardi L, Pistilli A, Arruda-Alencar J, Stabile AM, Rende M, Castellini C, Petrucci L, Parillo F, Moura A, Boiti C. Gene Expression and Localization 
of NGF and Its Cognate Receptors NTRK1 and NGFR in the Sex Organs of Male Rabbits. Reprod. Domest. Anim. 2015;50(6):918e25.

Marzoni M, Castillo A, Sagona S, Citti L, Rocchiccioli S, Romboli I, Felicioli A. A proteomic approach to identify seminal plasma proteins in roosters (Gallus gallus domesticus). Anim. Reprod. Sci. 2013;140:216-23.

Minelli A, Moroni M, Castellini C. Isolation and purification of the IGF-I protein complex from rabbit seminal plasma: effects on sperm motility and viability. J. Exp. Zool. 2001;290:279-290.

Mocé E, Vicente JS, Lavara R. Effect of freezing-thawing protocols on the performance of semen from three rabbit lines after artificial insemination. Theriogenology 2003;60:115-23.

Morrell JM. Artificial insemination in rabbits. British Veterinary Journal 1995;151(5):477-488.

Mosevitsky MI, Snigirevskaya ES, Komissarchik YY. Immunoelectron microscopic study of BASP1 and MARCKS location in the early and late rat spermatids. Acta Histochem. 2012;114:237-43.

Mukherjee DC, Agrawal AK, Manjunath R, Mukherjee AB. Suppression of epididymal sperm antigenicity in the rabbit by uteroglobin and transglutaminase in vitro. Science 1983;219:989-91.

Müller B. Studies on proteins identical to male and female genital tract secretions. Andrologia 1983;15:183-92.

Novak S, Smith T, Paradis F, Burwash L, Dyck M, Foxcroft G, Dixon W. Biomarkers of in vivo fertility in sperm and seminal plasma of fertile stallions. Theriogenology 2010;74:956-67. 
Nynca J, Arnold GJ, Fröhlich T, Otte K, Flenkenthaler F, Ciereszko A. Proteomic identification of rainbow trout seminal plasma proteins. Proteomics 2014a;14:13340.

Nynca J, Arnold GJ, Fröhlich T, Otte K, Ciereszko A. Proteomic identification of rainbow trout sperm proteins. Proteomics 2014b;14:1569-73.

Okabe M, Kishi Y, Ying X, Kohama Y, Mimura T, Li SS. Characterization of capacitation inhibitory protein from rabbit seminal plasma: Homology with human annexins. Biol. Pharm. Bull. 1993;16(5):453-6.

Ondruška L, Parkányi V, Rafay J, Chlebec I. Effect of LHRH analogue included in seminal dose on kindling rate and prolificacy of rabbits artificially inseminated. In Proc: $9^{\text {th }}$ World Rabbit Science Congress, 10-13 June, Verona, Italy 2008:s.122:423-6.

Pérez-Patiño C, Barranco I, Parrilla I, Valero ML, Martínez EA, Rodríguez-Martínez H, Roca J. Characterization of the porcine seminal plasma proteome comparing ejaculate portions. J. Proteomics 2016;142:15-23.

Petracci M, Bianchi M, Cavani C. Development of rabbit meat products fortified with n3 polyunsaturated fatty acids. Nutrients 2009;1:111-8.

Piehl LL, Fischman ML, Hellman U, Cisale H, Miranda PV. Boar seminal plasma exosomes: effect on sperm function and protein identification by sequencing. Theriogenology 2013;79:1071-82.

Pilch B, Mann M. Large-scale and high-confidence proteomic analysis of human seminal plasma.Genome Biology 2006;7:R40.

Pini T, Leahy T, Soleilhavoup C, Tsikis G, Labas V, Combes-Soia L, Harichaux G, Rickard JP, Druart X, de Graaf SP. Proteomic Investigation of Ram Spermatozoa and the 
Proteins Conferred by Seminal Plasma. Journal of Proteome Research 2016;15:3700-11.

Quintela LA, Pena Al, Vega MD, Gullón J, Prieto C, Barrio M, Becerra JJ, Herradón PG. Reproductive performance of rabbit does artificially inseminated via intravaginal administration of [des-Gly 10, D-Ala6]-LHRH ethylamide as ovulation inductor. Reprod. Domest. Anim. 2009;44:829-33.

Quintela LA, Pena Al, Vega MD, Gullón J, Prieto MC, Barrio M, Becerra JJ, Maseda F, Herradón PG. Ovulation induction in rabbit does submitted to artificial insemination by adding buserelin to the seminal dose. Reprod. Nutr. Dev. 2004;44:79-88.

Rebollar PG, Dal Bosco A, Millan P, Cardinali R, Brecchia G, Sylla L, Lorenzo PL, Castellini C. Ovulating induction methods in rabbit does: the pituitary and ovarian responses. Theriogenology 2012;77:292-8.

Redgrove KA, Anderson AL, Dun MD, McLaughlin EA, O'Bryan MK, Aitken RJ, Nixon B. Involvement of multimeric protein complexes in mediating the capacitationdependent binding of human spermatozoa to homologous zonae pellucidae. Dev. Biol. 2011;356:460-74.

Redgrove KA, Nixon B, Baker MA, Hetherington L, Baker G, Liu DY, Aitken RJ. The molecular chaperone HSPA2 plays a key role in regulating the expression of sperm surface receptors that mediate sperm-egg recognition. PLOS ONE 2012;7(11):e50851.

Rego J, Martins J, Wolf C, van Tilburg M, Moreno F, Monteiro-Moreira A, Moreira R, Santos D, Moura A. Proteomic analysis of seminal plasma and sperm cells and their associations with semen freezability in Guzerat bulls. J. Anim. Sci. 2016;94:5308-20. 


\section{General Discussion}

Rodríguez-Martínez H, Kvist U, Ernerudh J, Sanz L, Calvete JJ. Seminal plasma proteins: what role do they play? American Journal of Reproductive Immunology 2011;66:1122.

Safaa HM, Vicente JS, Lavara R, Viudes-de-Castro MP. Semen evaluation of two selected lines of rabbit bucks. World Rabbit Science 2008;16:141-148.

Silva $M$, Nino A, Guerra $M$, Letelier C, Valderrama XP, Adams GP, Ratto $M H$. Is an ovulation-inducing factor (OIF) present in the seminal plasma of rabbits? Anim. Reprod. Sci. 2011;127:213-21.

Slowinska M, Nynca J, Arnold GJ, Frohlich T, Jankowski J, Kozlowski K, Mostek A, Ciereszko A. Proteomic identification of turkey (Meleagris gallopavo) seminal plasma proteins. Poult. Sci. 2017;96:3422-35.

Souza CE, Rego JP, Lobo CH, Oliveira JT, Nogueira FC, Domont GB, Fioramonte M, Gozzo FC, Moreno FB, Monteiro-Moreira AC, Figueiredo JR, Moura AA. Proteomic analysis of the reproductive tract fluids from tropically-adapted Santa Ines rams. J. Proteomics 2012;75:4436-56.

Stewart JL, Mercadante VRG, Dias NW, Canisso IF, Yau P, Imai B, Lima FS. Nerve Growth Factor-Beta, purified from bull seminal plasma, enhances corpus luteum formation and conceptus development in Bos taurus cows. Theriogenology 2018;106(15):30-38.

Taha TA, Shaaban WF, EL-Nouty FD, Salem MH. Molecular approach of gossypolinduced reproductive toxicity in male rabbits. Electrophoretic pattern of seminal plasma proteins. Egyptian J. Anim. Prod. 2011;48(2):217-230. 
Tardif S, Wilson MD, Wagner R, Hunt P, Gertsenstein M, Nagy A, Lobe C, Koop BF, Hardy DM. Zonadhesin is essential for species specificity of sperm adhesion to the egg zona pellucida. J. Biol. Chem. 2010;285:24863-70.

Thomas TS, Wilson WL, Reynolds AB, Oliphant C. Chemical and physical characterization of rabbit sperm acrosome stabilizing factor. Biol. Reprod. 1986;3(5):691-703.

Trapani A, Lopedota A, Franco M, Cioffi N, leva E, García-Fuentes M, Alonso MJ. A comparative study of chitosan and chitosan/cyclodextrin nanoparticles as potential carriers for the oral delivery of small peptides. European Journal of Pharmaceutics and Biopharmaceutics 2010;75(1):26-32.

Topfer-Petersen E, Romero A, Varela PF, Ekhlasi-Hundrieser M, Dostalova Z, Sanz L. Spermadhesins: A new protein family. Facts, hypotheses and perspectives. Andrología 1998;30(4-5):217-24.

Vicente JS, Lavara R, Lavara F, Marco-Jiménez F, Viudes-de-Castro MP. Rabbit reproductive performance after insemination with buserelin acetate extender.Livestock Science 2008;115:153-7.

Vicente JS, Lavara R, Marco-Jiménez F, Viudes-de-Castro MP. Detrimental effect on availability of buserelin acetate administered in seminal doses in rabbits.Theriogenology 2011;76:1120-5.

Vicente JS, Viudes-de-Castro MP, Lavara R, Lavara F. Effect of male line on prolificacy from does inseminated with low sperm doses. In Proc: $7^{\text {th }}$ World Rabbit Congress, 47 July 2000, Valencia, Spain. Vol A: pp 273-277. 


\section{General Discussion}

Viudes-de-Castro MP, Lavara R, Marco-Jiménez F, Cortell C, Vicente JS. Ovulation induced by mucosa vaginal absorption of buserelin and triptorelin in rabbit. Theriogenology 2007;68:1031-6.

Viudes-de-Castro MP, Marco-Jiménez F, Vicente JS, Navarro E, Lavara R, Mocé E. Sperm kinetic parameters and differences in seminal plasma composition among two rabbit lines. In Proc: $8^{\text {th }}$ Annual Conference of ESDAR. Reprod. Dom. Anim. 2004, 39 (4), 266 (Abstract P13).WARSAW Agricultural University, Polonia.

Viudes-de-Castro MP, Mocé E, Lavara R, Marco-Jiménez F, Vicente JS. Aminopeptidase activity in seminal plasma and effect of dilution rate on rabbit reproductive performance after insemination with an extender supplemented with buserelin acetate. Theriogenology 2014;81:1223-8.

Wither MJ, Hansen KC, Reisz JA. Mass spectrometry-based bottom-up proteomics: sample preparation, LC-MS/MS analysis, and database query strategies. Curr. Protoc. Protein Sci. 2016;86(16):4.1-16.4.20.

Yi YJ, Manandhar G, Sutovsky M, Li R, Jonakova V, Oko R, Park CS, Prather RS, Sutovsky P. Ubiquitin C-terminal hydrolase-activity is involved in sperm acrosomal function and anti-polyspermy defense during porcine fertilization. Biol. Reprod. 2007;77:780793.

Zareie R, Eubel H, Millar AH, Baer B. Long-term survival of high quality sperm: insights into the sperm proteome of the honeybee Apis mellifera. Journal of Proteome Research 2013;12:5180-8.

Zeng C, He L, Peng W, Ding L, Tang K, Fang D, Zhang Y. Selection of optimal reference genes for quantitative RT-PCR studies of boar spermatozoa cryopreservation. Cryobiology 2014;68:113-21. 
Zhang H, Wang Y, Zhang J, Wang L, Li Q, Sheng X, Han Y, Yuan Z, Weng Q. Testicular expression of NGF, TrkA and p75 during seasonal spermatogenesis of the wild ground squirrel (Citellus dauricus Brandt). European journal of histochemistry $2015 ; 59: 2522$. 

X.CONCLUSIONS 



\section{X.CONCLUSIONS}

-The inhibition of rabbit seminal plasma peptidase activity by a protease inhibitor cocktail affects reproductive performance decreasing prolificacy.

-The use of AMIs (bestatin and EDTA) in order to inhibit part of the aminopeptidase activity is not enough to allow us to reduce the GnRH concentration in the insemination extender without affecting fertility.

-The encapsulation of the GnRH analogue by chitosan-dextran sulfate nanoparticles in the insemination extender, makes possible to diminish the hormone quantity in a $20 \%$ (from 5 to $4 \mu \mathrm{g} /$ doe), without altering rabbit reproductive performance.

-Rabbit seminal plasma and sperm proteins are mainly related to catalytic and binding activity with only six and seven of them known to be involved to date in reproduction processes, respectively.

- $\beta$-NGF protein was identified and quantified for the first time in rabbit seminal plasma. This protein only represents about $1.4 \%$ of the total protein amount in rabbit seminal plasma and its quantity is independent of the genotype.

-Genotype is the main reason for the protein abundance differences observed between rabbit genetic lines $A$ and $R$. There are slight protein differences between seasons but it does not exist a clear pattern of protein variation along the year in both genotypes.

-The first publicly accessible database of the rabbit seminal plasma and sperm proteome was created. 

XI.SUPPLEMENTARY TABLES 



\section{XI.SUPPLEMENTARY TABLES}

\section{CHAPTER V. RABBIT SEMINAL PLASMA: THE IMPORTANCE OF THE GENETIC ORIGIN.}

Table S5.1. contains the complete list of the 402 proteins identified in rabbit seminal plasma with a cut off of two unique peptides and validated with $\geq 95 \%$ Confidence (unused Score $\geq 1.3$ ).

Table S5.2. contains the complete list of the chromatographic areas of the 402 proteins identified in the two rabbit genotypes and the four seasons ( 3 replicates per sample).

Table S5.3. shows the results of the protein quantity T-test comparison between genotypes, including mean protein quantity, t-value, $p$-value, fold change and log (fold change) of the 402 quantified proteins.

\section{CHAPTER VI. CHARACTERIZATION OF RABBIT (ORYCTOLAGUS}

\section{CUNICULUS) SPERM PROTEOME.}

Table S6.1. contains the complete list of the 487 proteins identified in rabbit spermatozoa with a cut off of two unique peptides and validated with $\geq 95 \%$ Confidence (unused Score $\geq 1.3$ ).

Table S6.2. contains the complete list of the chromatographic areas of the 487 proteins identified in the two rabbit genotypes ( 3 replicates per sample).

Table S6.3. shows the results of the protein quantity T-test comparison between genotypes, including mean protein quantity, $t$-value, $p$-value, fold change and log (fold change) of the 487 quantified proteins. 